


\section{LIBRMI \\ FACULTY OF FORESTRY UNIVERSITY OF TORONTO}


Digitized by the Internet Archive in 2007 with funding from Microsoft Corporation 


\title{
COLONIAI, REPORTS-MISCELLANEOUS.
}

No. 66.

\section{GOLD COAST.}

\section{REPORT ON FORESTS;}

BYY

\author{
Mr. H. N. 'THOMPSON, \\ Conservator of Foreste, Southern Niguriat
}

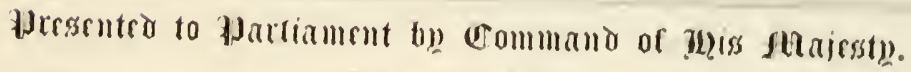
Janumry, 19)(\%)

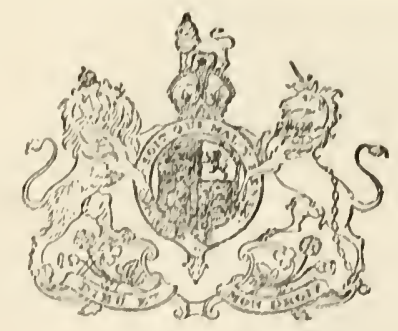

minteis JOR HIS MONDON :

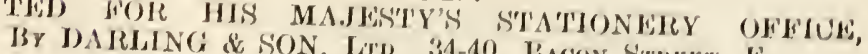

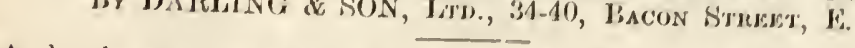

And to be rurchased, either directly or through any booksollor, from

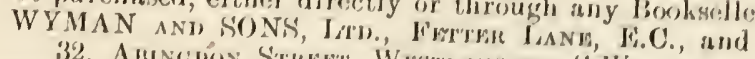

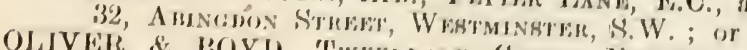

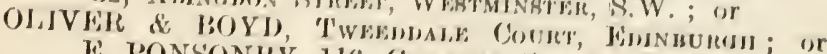

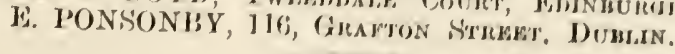

[Cd. 499:3.] Price 1s. 1d.

$$
1910 .
$$




\section{PART I}

Examination of Forests and Description of Journeys made through THEM.

Page.

1. Description of journey from Accra to Aburi and back $\quad \ldots \quad$... 7

2. Description of journey from Accra to Sekondi and the saw-mills at

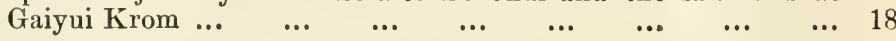

3 Description of journey across the lower valleys of the Ankobra and Tano rivers through the districts of Lower Wassaw, Lower Denkira, and thence back to the railway at Dunkwa $\quad \ldots \quad \ldots \quad 24$

$\begin{array}{lllllll}\text { Forests between Tarkwa and Prestea... } & \ldots & \ldots & \ldots & \ldots & 25\end{array}$

$\begin{array}{llllllll}\text { The fuel supply for the gold mines } & \ldots & \ldots & \ldots & \ldots & \ldots & 30\end{array}$

Forest vegetation of the central portion of the Ankobra drainage 31

The forests between Ahirisu (Mansi river) and N'Kwansia (on

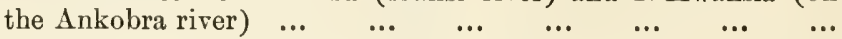

The forests between the Ankobra river, and its feeder the Sibiri

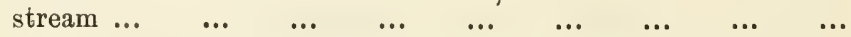

The forest on the south-eastern slopes of the Ankobra-Tano

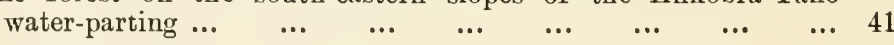

The forests in the drainage area of the Lower Tano river... $\quad \ldots \quad 42$

Forests between Tomento and the railway line at Dunkwa station 46

4. Supply of fuel for the Tarkwa and Abosso mines $\quad \ldots \quad$... $\quad \ldots \quad 49$

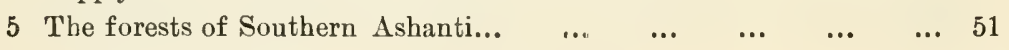

$\begin{array}{lllllllll}\text { General remarks... } & \ldots & \ldots & \ldots & \ldots & \ldots & \ldots & \ldots & 51\end{array}$

$\begin{array}{lllllllll}\text { The Tsifufu forests } & \ldots & \ldots & \ldots & \ldots & \ldots & \ldots & \ldots & 55\end{array}$

The forests between Oboase and the village of Hun on the Adra

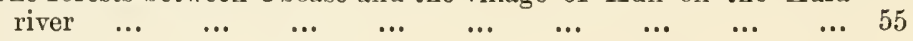

Forests between the confluence of the Adra and Offin rivers and

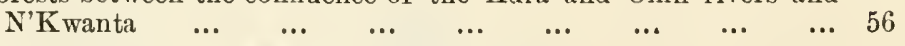

$\begin{array}{lllllll}\text { The forests north of Mansu N'Kwanta } & \ldots & \ldots & \ldots & \ldots & 57\end{array}$

The forests between Impasatia and Bibiani ... $\quad \ldots \quad \ldots \quad \ldots \quad \ldots 60$

The forests between Bibiani and Mim (Tano river drainage) $\quad \ldots \quad 61$

The forests of the upper portion of the Bia river drainage $\quad \ldots \quad 63$

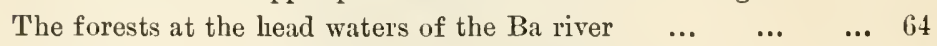

6. The forests of North-western Ashanti belonging to the Volta river $\begin{array}{llllllllll}\text { drainage } & \ldots & \ldots & \ldots & \ldots & \ldots & \ldots & \ldots & \ldots & 67\end{array}$

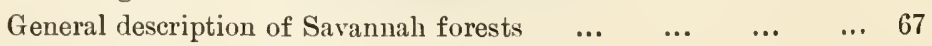

$\begin{array}{lllllllll}\text { The forests near Braha } & \ldots & \ldots & \ldots & \ldots & \ldots & \ldots & 73\end{array}$

$\begin{array}{lllllllll}\text { The forests near Oboase } & \ldots & \ldots & \ldots & \ldots & \ldots & \ldots & 74\end{array}$

The vegetation near the Volta at Tonkomia... $\quad \ldots \quad \ldots \quad \ldots \quad \ldots \quad 74$

The forests between Bian and Jugbe (Northern Territories) $\quad . .74$

$\begin{array}{llllll}\text { 'The forests in the neighbourhood of Kintampo } & \ldots & \ldots & \ldots & 75\end{array}$

$\begin{array}{lllllllll}\text { Return journey to Kumasi } & \ldots & \ldots & \ldots & \ldots & \ldots & \ldots & 76\end{array}$

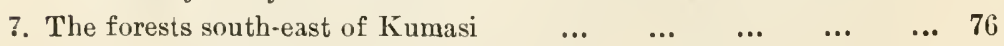

The nronosed Dampia reserve $\ldots \begin{array}{llllllll} & \ldots & \ldots & \ldots & \ldots & \ldots & 78\end{array}$

8. The forests between the Cane Coast road and Lake Bosumptwi $\quad$.. 79 
9. The forests between Lake Bosumptwi and the Anum river ...

10. The forests between the Anum river and Odumase $\quad \ldots \quad \ldots \quad \ldots 80$

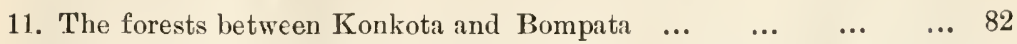

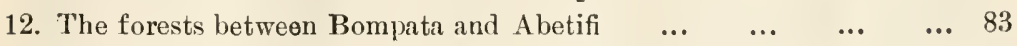

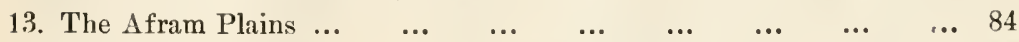

General description of country and vegetation $\quad \ldots \quad \ldots \quad \ldots \quad \ldots \quad 84$

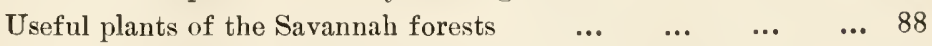

$\begin{array}{lllllll}\text { Country between Abetifi and Aframsu } & \ldots & \ldots & \ldots & \ldots & 94\end{array}$

Country hetween Aframsu and Jwafuabutan $\quad \ldots \quad$... $\quad \ldots \quad 94$

$\begin{array}{lllllllll}\text { Big game and game laws } & \ldots & \ldots & \ldots & \ldots & \ldots & \ldots & 95\end{array}$

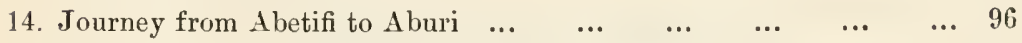

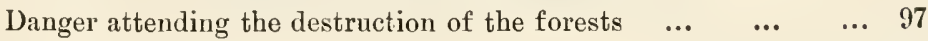

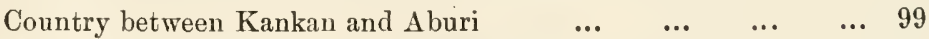

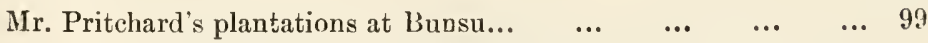

Agricultural prospects of Eastern Ashanti, Kwahu, Akyem, and

$\begin{array}{lllllllllll}\text { Aburi } & \ldots & \ldots & \ldots & \ldots & \ldots & \ldots & \ldots & \ldots & \ldots & 100\end{array}$

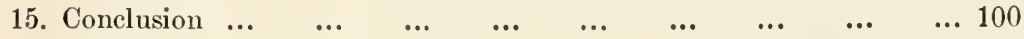

\section{PART II.}

\section{A.-Protection of Forests and Forest legislation.}

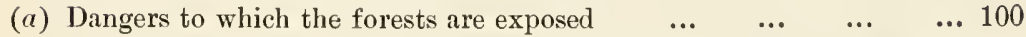

(b) Dangers attending and following the reckless destruction of the

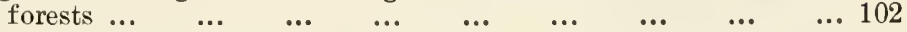

(c) Methods of protecting the forests from the dangers mentioned above 106

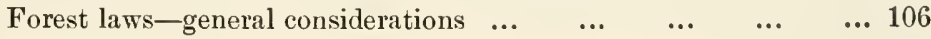

$\begin{array}{llllllllll}\text { Enactments necessary } & \ldots & \ldots & \ldots & \ldots & \ldots & \ldots & \ldots & 106\end{array}$

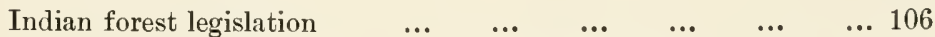

Its application to certain areas in the Indian Empire $\quad \ldots \quad \ldots 107$

Suitability of the Indian laws (with modifications) to our West

African Colonies and Protectorates... $\quad \ldots \quad \ldots \quad \ldots \quad \ldots \quad \ldots 110$

Forest administration of the Southern Shan States of Burma $\quad$... 111

Southern Nigerian forest laws based on the Burma forest laws ... 113

Southern Nigerian forest laws, with certain modifications, suitable for the Gold Coast and its dependencies $\quad \ldots \quad \ldots \quad \ldots \quad \ldots \quad \ldots 113$

Importance of continuity of policy and action in forest adnrinis-

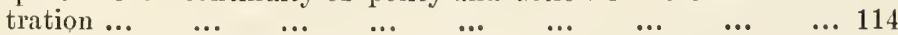

(d) Southern Nigeria forest laws as modified for application to the

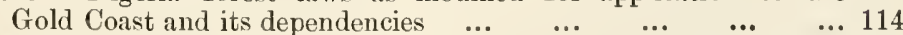

Orders of His Majesty the King in Council for the good government of the Gold Coast. Ashanti, and the Northern Territories 115

The Southern Nigeria Forestry Ordinance-modifications and

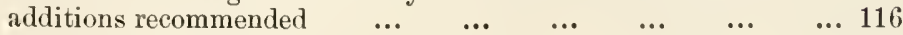

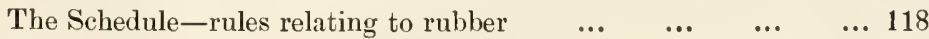

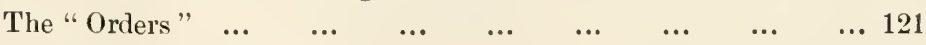

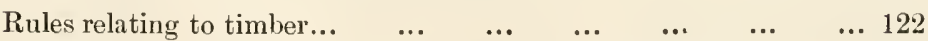

Reasons for recommending a high minimum felling girth ... $\quad . .123$

Additional rules (control of forest produce in transit) $\quad \ldots \quad \ldots 127$

$\begin{array}{lllllll}\text { Classification of hammer marks } & \ldots & \ldots & \ldots & \ldots & \ldots & 127\end{array}$

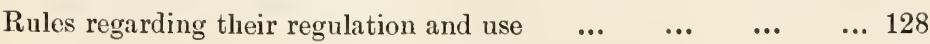

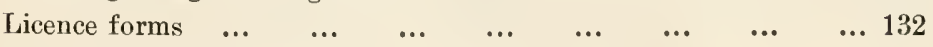

(12315-2) Wt. 26122-322. 1125. 1/10. D \& S.

A 2 
(d) Southern Nigeria forest laws-cont.

$\begin{array}{lllllllll}\text { Timber removal pass } & \ldots & \ldots & \ldots & \ldots & \ldots & \ldots & \ldots & 133\end{array}$

$\begin{array}{llllllllll}\text { Drift timber } & \ldots & \ldots & \ldots & \ldots & \ldots & \ldots & \ldots & \ldots & 133\end{array}$

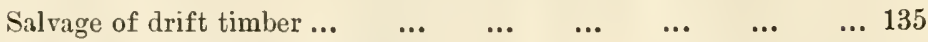

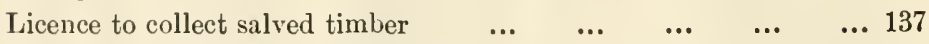

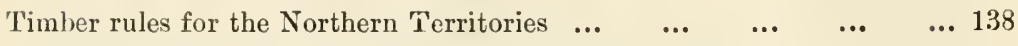

$\begin{array}{llllllll}\text { Trade licence to take timber } & \ldots & \ldots & \ldots & \ldots & \ldots & \ldots & 138\end{array}$

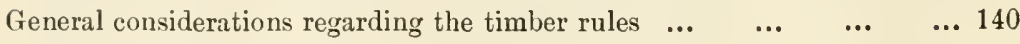

$\begin{array}{lllllllll}\text { Rules relating to forest reserves } & \ldots & \ldots & \ldots & \ldots & \ldots & \ldots & 141\end{array}$

3.-Suggestions as to the Forest Policy and Administration to BE ADOPTED ON THE GOLd COAST.

$\begin{array}{lllllllll}\text { A. Forest establishments } & \ldots & \ldots & \ldots & \ldots & \ldots & \ldots & \ldots & 142\end{array}$

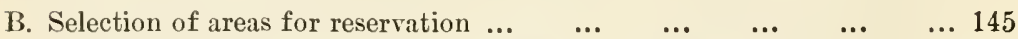

C. The collection of data for the preparation of working plans $\quad \ldots \quad$... 148

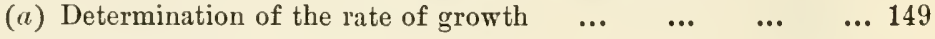

(b) Determination of the proportion existing between the various

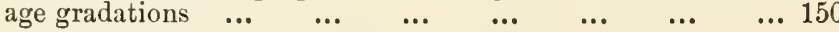

$\begin{array}{llllllll}\text { Linear valuation surveys } & \ldots & \ldots & \ldots & \ldots & \ldots & \ldots & 151\end{array}$

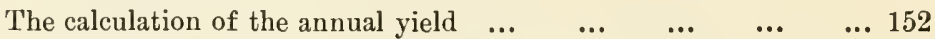

Approximate methods suitable for West Africa $\quad \ldots \quad \ldots \quad \ldots \quad \ldots 152$

Sylvicultural methods of exploitation recommended-Selection

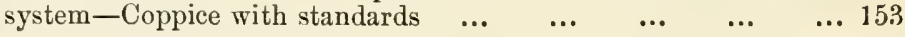

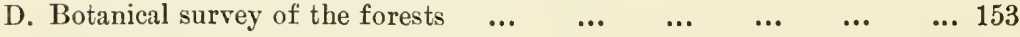

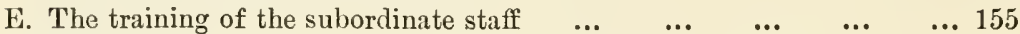

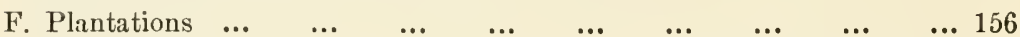

G. The inspection and supervision of timber concessions and licensed

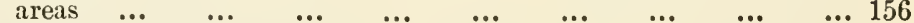

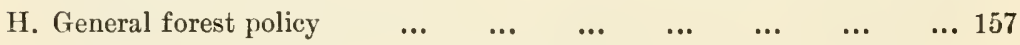

\section{PART III.}

C.-Conclusion.

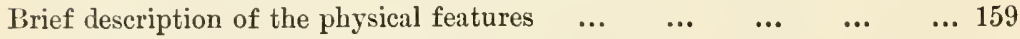

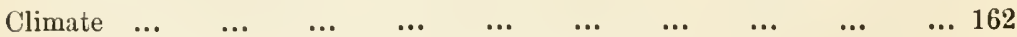

Short account of the conditions affecting plant growth $\quad \ldots \quad \ldots \quad \ldots l 66$

Classification of plant formations $\quad \begin{array}{lllllllll} & \ldots & \ldots & \ldots & \ldots & \ldots & \ldots & 170\end{array}$

Types of West African formations and their characteristic plants $\quad \ldots 170$

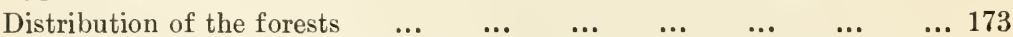

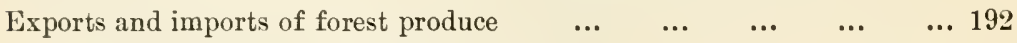

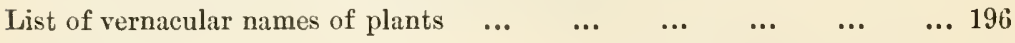

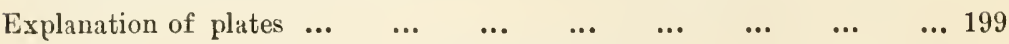

APPENDIX.

$\begin{array}{llllllllll}\text { The Forestry Ordinance } & \ldots & \ldots & \ldots & \ldots & \ldots & \ldots & \ldots & & \ldots\end{array}$

INDEX.

[References to the plates accompanying this report will also be found in the List of Vernacular Names of Plants given on pp. 196-199.] 
No. 66.

\title{
G OL D COA S T.
}

\author{
REPORT ON FORESTS.
}

\section{IN'TRODUCTION.}

For some years past the Government of the Gold Coast had been endeavouring to procure the temporary services of an Indian Forest Officer with a view to getting professional advice on the best means of regulating the haphazard methods of exploiting the mahogany forests then in vogue.

Their object was to secure a report on the forest resources of the country and the measures that should be adopted for the preservation of the forests against excessive exploitation.

For one reason or another such an officer could not be found, and it was finally decided that my services should be lent for that purpose by the Southern Nigerian Government for a period of four months.

Accordingly, on the expiration of my year's (1907) tour in the latter Colony and Protectorate, I left Lagos by steamer on the 31st December, 1907, and arrived at Accra on the following day, the 1st January, 1908. After remaining there a few days and making a short visit to the Botanical Gardens at Aburi, I returned to the former town and sailed for the Port of Sekondi on the 8th of the same month; from there I began my series of tours through the forests of the Colony and Ashanti.

In Part I. of this report, I have described, in some detail, the trips made through the forests and the character of the country and the vegetation passed through.

Part II. is devoted to a discussion of the measures that should be introduced with a view to conserving the forests and initiating a sound system of forest policy for their management and development.

In Part III. a brief summary is given of the phrsical features and climate of the Gold Coast and Ashanti, of the vegetation of those countries, the distribution of the forests, a short account of the conditions affecting plant growth and their influence in determining the geographical distribution of plants, statistics of the exports and imports of forest produce, and an estimate of the future yield of timber from the forests. 
The main principles guverning the distribution of plant life, though well known to botanists and professional foresters, are not so universally appreciated by the general public.

With a view to placing before the latter a concise account of the reactions of regetation $\left.\right|_{N}$ the environment, and thus enabling them to intelligently follow the principles on which forest conservancy is based, I have ventured to introduce subjects that may otherwise be considered foreign to a report of this character. If, however, by doing this I can induce even a few of the Political Officers in charge of our West African Colonies and Protectorates to take some interest in forest protection, and realise the very important transformations in climate and type of regetation that are liable to follow the. wholesale destruction of the forests, then my action will be fully justified.

In its initial stages, at all events, forest conservancy must to a large extent depend, as far as its successful application goes, on the attitude displayed towards it by the Political Officers.

The period of four months, for which my services were originally lent, having proved insufficient for completing the examination of the forests, I was permitted to extend it to six months; this enabled me to visit some of the rooded areas of the eastern portions of the Colony and Ashanti; but, even with this extension, I am afraid that I lave left unvisited many important forests. 'To thoroughly explore the whole country would require two or three years' continuous work of that kind.

With the limited time at my disposal it was a matter of some difficulty to decide on the best routes to take, but I was eventually influenced in my choice by the consideration that it was more important to discover what forests were left intact, and to explore wooded areas about which but little was known, than to occupy the bulk of my time with forests that have already been pretty well exploited. 'The latter, however, were not neglected; during my wanderings through the forests of the lower Ankrobra and Tano River basins, and those along the Sekondi-Kumasi Railway, where exploitation is in full swing. I saw enough of the methods employed there of felling and extracting the timber to enable me to form a pretty good estimate of the character of the work and the extent to which the wood-producing capital has been removed.

I take this opportunity of thanking all those officials of the Gold Coast and Ashanti, to whom I an indebted for much kindness and assistance in connection with my duties, more especially to Major C. H. Armitage, D.S.O., the Acting Chief Commissioner of Ashanti; Mr. F. G. Crowther, the Acting Secretary for Native Aftairs; the Acting General Manager of the Gold Coast Railway; Mr. A. J. Philbrick, the Provincial Commissioner of the Western Province of the Colony; Captain G. W. C. Soden, Provincial Commissioner, Ashanti; to Mr. K. Burbridge, Curator. the latter of whom accompanied me throughout mr tours: and to the Agricultural Department, grenerally, of the Gold Coast. I have also received much help and useful information from Mr. G. A. Stockfeld, General Manager of the 
'Tarquah and Abosso Mines; Mr. Mc'Tear, General Manager of the Ashanti Goldfields Corporation; the Manager of the Bibiani Mines; and from Messis. Nicholas and Brett; to all of whom I now ofter my sincerest thanks. I wish also to express my indebtedness to Dr. Otto Stapf and other officials of the Royal Botanic Gardens, Kew, for their assistance in identifying and naming specimens collected during my tours.

I cannot conclude without expressing my great obligations to the Governor, Sir John Pickersgill Rodger, K.C.M.G., and Acting Governor Major H. Bryan, C.M.G., to whose initiative and constant interest is due any success that may have attended my risit to the Colony and Ashanti.

\section{H. N. Thompson,}

Conservator of Forests, Southern Nigeria.

December, 1908.

\section{PART I.}

Accra.-The small cocoanut plantation situated to the northeast of Christianborg Castle is not a success. The young plants have suffered much from the annual fires, and their growth has been considerably checked in consequence.

Those which have grown high enough to escape damage from the fires are doing better, but the whole plantation is too much exposed to the strong sea breezes for the young palms to escape distortion; the stems of the majority of them are bent over towards the north-east at an acute angle.

The country about here is very arid, and this, coupled with the fact that the salt spray is blown inland a good distance bаск from the beach, accounts for the serophitic habit of the veretation occupying it; most of the indigenous plants along the shore, and for a mile back, possess thick succulent leaves, and even some of the grasses have become modified in this respect.

The vegetation is scrubby, consisting mainly of dwarfed acacias, a species of Capparis (caper), a Bridelia (Euphorbiacea), and a Convolvulus. Amongst introduced plants the prickly pear (Opuntia), aloes, and euphorbias are most conspicuous, and have done best because their xerophilous structure is suited to the environment.

In the gardens belonging to Government House, I noticed that some casuarinas planted there were, considering the soil and climate, doing very well indeed, and that Pithecolobium saman. was also flourishing. In these two plants we possessi a ready means of reclaiming the land along the seashore, and making it suitable for cultivation. The two great dangers to guard against are: first, the strong prevalent winds impregnated with 
salt spray; and, second, the annual scrub fires that are so common during the dry season. These dangers can be best met by planting up the coast-line with a broad belt of casuarinas, then behind them casuarinas and pithecolobiums, mixed, to form a wind-break, and behind that, again, a mixture of deciduousleaved and evergreen trees. The wholo belt of tree vegetation should be at least half-a-mile broad. Simultaneously with this, planting measures should be taken to ensure effectual protection against fire for the belt so formed. I understand that firewood is scarce ill Accra, and has to be brought from the foot-hills to the north of the town, a distance of some miles. Here, again, by the creation of fuel reserves and effective fire protection, a cheap and constant supply of fuel can be ensured, and, in addition, the soil can be enriched, protected, and eventually made capable of bearing fairly good agricultural crops. As things stand at present, the fertility of the soil is being gradually destroyed year by year, and there is no doubt that a time will come when it will be incapable of supporting vegetation of any economic value.

Re-afforestation, combined with adequate fire protection, will prevent such a disastrous state of affairs, and play a prominent part in re-establishing the fertility of the soil, increasing the fuantity of water held by it in suspension, and eventually making it suitable for agricultural purposes.

The Accra Plains.-On my way to Aburi I had an opportunity of observing the character of the vegetation growing on the plains between Accra and the foot-hills of the range on which Aburi is situated. As far up the road as Kamantang the country is very arid and covered with scrubby vegetation. The lattes consists mainly of dwarfed acacias (probably Acacia catechu), a spiny Capparis, Bridelia, Euphorbias, a few scrambling Combretums and short grass. The introduced opuntias (prickly-pear cactus) and agaves are also growing here and there as escapes. The soil consisting mainly of weathered laterite is but poorly covered with vegetation, and is often exposed in large patches, but in the hollows, formed by old dried-up watercourses, where alluvial deposits exist, a rank growth of fairly long coarse grass has sprung up, and gives a certain amount of protection to the soil. Trees, except those planted by man, are scarce on the plain. 'The most characteristic wild ones are the fan palmBorassus fabelliformis var. aethiopica, an arboreal Euphorbia with a thick woody stem, succulent fleshy leares, and a rounded crown, and two species of baobabs (Adansonia). These trees, however, are few and far between and do not alter the general scrubby character of the regetation, which is typical of the arid plains of West Africa. On allurial patches the fan palm is inclined to be gregarious. The whole of this plain is subject to fires, and at the time of my visit the scrub was burning in all directions. It is on these plains that re-afforestation and fire protection will give the best results.

The Savannah Forests.-Between Kamantang and the main Aburi range the low scrub regetation, described above, gives 
place to the open park-like grass country so common in West Africa behind the forest belts found near the coast.

These Savannah forests represent the intermediate stage of vegetation between the true forests and the dry scrub of the arid regions. The soil is covered with a coarse long grass and trees of several species as well as shrubs are found dotted about, often in small groups and sometimes in regular belts (fringing regetation) along the moister hollows.

The rainfall in such Savannah forests is not sufficient to enable ordinary tree vegetation to compete successfully with the grasses, which with the help of the annual bush fires can keep such vegetation in check. In the moister alluvial hollows tree growth still continues to hold its own against the grasses, but the destruction of the former by man results in a gradual deterioration of the fertility of the soil, its desiccation, and the eventual conversion of the Sarannah forests into pure Savannahs and the arid scrub of the Accra plains. Every stage in this process can be recognised along the road leading to Aburi.

The vegetation usually met with in the Savannah forests consists, amongst shrubs, of the wild custard apple, Anona senegalensis, Sarcocephalus esculentus, Bauhinia reticulata, Zizyphus mucronuta and a species of Capiaris, whilst trees are represented by Acacia catechu, Acacia Sieberiana, Entada soudanica, Ormosia laxiflora, Pterocarpus erinaceus, Vitex cuneata, Vitex megaphylla, two or three species of Parinarium, Parkia filicoidea, a small Pseudocedrela, the balsam copaiba tree, Daniella thurifera, Lophira alata and the shea butter tree, Butyrospermum Parkii. The three last trees, however, appear to be absent from the Savannahs through which the Accra-Aburi road passes. Probably the locality is too close to the sea to suit the requirements of these plants. In addition to the plants mentioned above, others, such as the fan palm (Borassus fabelliformis var. cethiopica) and species of Adansonia (Baobabs), are also to be met with in the Savannah forests.

The evergreen forests.-As one approaches the foot of the main hill ranges close to Aburi, the Savannahs gradually merge into the ordinary evergreen forests which are the richest in variety of species of any of the types met with in Africa. Is a rule, where such forests have not been much interfered with by man, the leaf canopy is fairly complete, the soil is well protected from the sun and atmospheric agencies by a dense undergrowth of shrubs and young trees, and the forest has all the characteristics of what is technically known as "high forest."

The variety of species is great and includes most of the West African plants of economic importance. It will be sufficient for the present to give only a brief list of the more important species forming this type. They are:-The Dahomah (Piptadenia africana), one of the most common trees on the Gold Coast, the Assohma (Parlia species) almost equally common, the Ahfram, the Opapao (Afzelia africana), the Elu (Bombax buonopozense), the Honum (Anthocleista magnifica), the Ofu 
or. (Then-chen (Antiaris toxicurin var. africana), the Prekese (Tetrepleure Thonningii), the ()doum (Chlorophora excelsa), the Intrini (Khayn species), the Penkwa ('seudocedrela cylin(rica), the Tiama-Tiama (Pseudocedrela sp.), the N'yankom or Inalion (Heritiera "tilis), the Pepedum (Lovoa Klaineana), the Kolioti (Pynaertia ealaensis), the Affram or Offram (Termim"lin superba), Funtumia elastica, Funtumia africana, the Emil or Emril (Terminalia sp.), the Kaku (Lophira procera), the Balile (Mimusops Djave), the WTaw-waw (Triplochiton Johnsomii), the Athawah (Pentaclethra macrophylla), the Meinchin (P'cltophorum sp.), the Ehyedua (Cyanothyrsus species), the Orama (Ricinodendron africanus), the Baya or Yaya (Mitray!yue macrophylla), Macrolobium stipulacenm, the Ote (Myrislica species), the Nyamedua (Alstonia congensis), Musanga s'mithii, Myrianthus arboreus, Huronga madagascariensis, Sterculia cordifolia, C'ola Afzelii, Eriodendron anfractuosum, and a host of others, some of which, for want of the flowers and fruit, I have not yet been able to identify or get identified.

The Aburi hills were once clothed with this type of vegetation, and the remnants of the old forest can still be seen in the form of large isolated examples of Piptadenia africana, Triplochiton Johnsonii, Antiaris toxicuria var. africana, Chlorophora excelsa, Partia biglobosa, various species of Ficus, Eriodendron anfractuosum, Bombax buonopozense, the Offram (Terminalia sp.), Kokoti (Pynaertia ealaensis), Baku (Mimusops Djave), \&c., which, on account of their" size, were left as "standards" when the natives cleared the forests for their farms.

Under these "standards," where the soil is unoccupied at present by agricultural crops, a dense tangled mass of secondary growtl has sprung up consisting mainly of Musanga Smithii, Myrianthus arboreus, Haronga madagascariensis, the oil palm, various species of Combretum, Landolphia, Clitandra, Gloriosa superba, Inthocleista magnifica, \&c., and a few suppressed seedlings of the Waw-waw (Triplochiton Johnsonii), the Emril, and the shingle tree (Terminalia scutifera); clearings in the secondary growth have been planted up with cocoa and in places with cola; extensive areas are also under cassava and corn, and it is on these areas that denudation of the hillsides is proceeding most rapidly.

The Aburi hill forests, situated as they are on the edge of the arid plains to the north of Accra, are. of course, exposed to all the dangers which attend such proximity to an extensive centre of desiccation.

'The abandoned (fallow) cassava farms, especially those on the steeper slopes, have been occupied by the coarser grasses. As the latter are burnt every rear, the soil becomes exposed and is washed away during the rainy season and then denudation of the hillsides begins. It is already in full operation on several of the minor ridges and the process is being continued at a rapid pace. Once the soil becomes exposed it is no longer capable of storing and regulating the supply of moisture for the springs; the latter begin to dry up, as they have actually 
done in two instances close to Aburi, where, according to the natives, an abundant supply of water was formerly available. Concurrently with this diminution of the moisture held in suspension by the soil, the character of the regetation alters, plants characteristic of drier regions gradually occupy the land and replace those typical of the evergreen hill forests, and slowly but surely the whole aspect of regetation changes. Once the forests become dry and deciduous they are more than ever exposed to damage from forest fires, and any clearings made in them for farming purposes are erentually occupied by various species of grasses. When this stage is reached it may be said that the end of forest regetation is close at hand.

Under existing agricultural practice there is nothing whatever to stop the gradual spread of the arid country into the very heart of the forest region and that is what will undoubtedly take place unless efficient barriers against its spread are created. such barrier's are even now available, provided that the forests occupying the hill ranges which border the arid plains are strictly protected against farming and against forest fires. The protected area should include the catchment basins on the left banks of the upper reaches of the Densu and Birrim Rivers. Behind this barrier and under its protection the cultivation of such plants as cocoa, cola, \&c., which require a moist climate, can be carried on in safety, as they will no longer be exposed to the direct action of the arid regions.

As matters now stand there is every indication that the cocoa plantations on the hills facing the plain are doomed to destruction at an early date. The regetation here is already altering in character from the evergreen to the deciduous type, and the change is so pronounced that the Acting Director of Agriculture estimates the life of a cocoa tree at not more than six or seren years in this locality. What is more important, however, is the fact that the damage is not likely to end here. "The process of substitution will progress till the rery heart of the forest country is involved. Such changes will jeopardise the palm-oil industry as well as bring about a general reduction in the fertility of the soil.

The changes described above have been retarded to a certain extent on the main Aburi range by the fact that this range is of sufficient altitude (1,600 feet) to condense the water vapour held in suspension by the moist sea breezes when the latter strike it and are forced up the slopes facing the sea.

'This condensation is very marked at night and gives rise to the dense, dripping mists that are such a noticeable feature of the Aburi Hills even at the driest season of the year. Such uight mists are very favourable to plant growth, especially in the tropics; they must have an appreciable effect in delaving the progress of the usual changes that follow the destruction of forests in hot climates. Nevertheless, beneficial as they are, they can never compensate for so decided a diminution of the rainfall as has apparently taken place at $\Lambda$ buri during the last eight vears.

The rainfall records of this station for the sixteen vears 1892 to 1907 show that the averagre rainfall for the first period of 
eight years, viz., 1892 to 1899 , is 49.92 inches with maximum and minimum respectively of $66^{\circ} \cdot 74$ and $40 \cdot 64$ inches, as against an average of $43 \cdot 34$ inches and maximum and minimum of 50.53 and 32.09 inches respectively for the second period of eight years, viz., 1900 to 1907 .

'l'hus the average decrease has during this latter period been at the rate of approximately $\frac{3}{4}$ inch per annum, a very high rate indeed, and one which explains the invasion of the outlying hills bordering the plains by deciduous-leaved species.

The change from evergreen regetation to that of the deciduous type means forest fires, and the latter in their turn mean the dominance of grasses at the expense of tree vegetation.

\section{Botanical Gardens.}

My stay at Aburi gave me an opportunity of examining the Botanical Gardens at that station and appreciating the large amount of useful work that has been carried out there in a quiet and unostentatious manner. In addition to the various plots planted up with species of agricultural importance, special attention has been paid to collecting and growing a representative series of the rubber and latex-yielding plants of tropical countries, more particularly those from West Africa.

The genus Ficus is well represented and the collection contains, amongst others, quite a large number of specimens of $F$ icus clastica and Ficus Vogelii. I am informed that the yield of rubber from the former has been very disappointing and nothing like as abundant as that obtained from the latter. Moreover, the rubber from this species as grown in the gardens appears to contain a higher percentage of resins than does the corresponding product from trees grown in the East. The rubber from $F$. Vogelii sells in the home markets at the rate of $2 s$. per pound, whilst that of the Ire or silk rubber tree, Funtumia elastica, commands only $6 d$. a pound more in price. It is evident then that $F$. Vogelii is quite a valuable rubber producer and its cultivation on a large scale is worth undertaking; it is of importance to note that it is a native of the country and not an exotic.

A fairly large plot has been planted with Castilloa elastica; but without exception every tree has been seriously attacked by a borer, and some of them even killed outright by the damage done to them. "This excellent rubber yielder appears to suffer from similar attacks wherever it has been planted in Southern Nigeria. In the Botanical Gardens at Calabar, however, the damage done is very much less, and one or two good healthylooking trees that have escaped from their attacks are to be found there. In the Olokemeji and Ebuta Metta Gardens of the TVestern Province (Lagos) the species has been practically exterminated by these insects. It may be that the comparatively poor rainfall of the Aburi and the two last-mentioned Gardens has something to do with the extent of the damage and the prevalence of such attacks.

Experiments are being carried out in the cultivation of one of the numerous species of Ceara rubber trees, viz., Manihot 
precosa, which is said to yield rubber at a very early age. The individuals that have been planted are however much too small at present to stand tapping; hence the statement cannot yet be verified. Hevea brasiliensis does not appear to do very well up here, probably on account of the deficient rainfall; the yield of latex from all the trees originally tapped in 1903, when they gave an average of half a pound of rubber per tree, has now fallen off considerably, and in some cases ceased altogether. This again is possibly due to the light rainfall. So far as I am aware no other fairly large trees of this species have been tapped annually in West Africa with a view to ascertaining whether the output of the rubber falls with advancing age or not, but in any comprehensive scheme for planting up large areas in West Africa with this species, the possibility of a reduced yield should not be overlooked. The Para rubber plantations seen by me at Tarkwa and Kumasi, where the rainfall is very much heavier, show excellent growth and promise to give just as good results as those obtained in the East. However, time alone can decide this question definitely.

Both as regards rate of growth and yield of rubber this species is decidedly superior to the indigenous Funtumia elastica; it is also apparently a more hardy type as far as experience on the Coast goes; but there is still the uncertainty as to a sustained annual yield of latex. Three other exotic species of rubber trees have been introduced into the West Coast of Africa, but they have up to now proved failures so far as yield of rubber is concerned. They are Ficus elastica, Manihot Glaziovii, and Castilloa elastica; but the last has failed more on account of damage by insects than from any other cause, and further experiments should be tried.

Funtumia elastica.-This species is doing well at Aburi, especially on the slopes facing the south-west, where the growth of five years is very good and is nearly equal to that of the Para trees of corresponding age planted in other parts of the garden. The former species was planted along strips cleared in secondary forest growth; the intervening uncut bush was then in its turn gradually removed in strips and similarly planted up with Funtumia clastica. This process was continued till the whole area had been gone over in this manner.

A few specimens of Funtumia latifolia are to be seen in the gardens. They are said to yield a very poor quality rubber.

Landolphia owariensis.-This species has been planted at the foot of the trees forming the avenue leading up from the Aburi Post Office to the Curator's house. The vines appear to be healthy enough, but the growth is slow, especially in diameter. The young leaves are at first of a deep reddish brown colour.

Fibre plants.-These are well represented and several plots of land in one portion of the gardens have been put aside for their cultivation. All the more important species are to be seen growing there.

\section{Timber Trees.}

Several exotic species have been planted out, and a few of them show good growth. Of these the most important is:- 
Cedrela odorata, one of the West Indian cedar trees. The examples of this species in the gardens show a remarkable wrowth for their age. Individuals only some sixteen years old have accuined a height of from 50 to 60 feet and a girth of between 5 and 6 fect at breast height. A danraged tree was felled and the wood showed very rapid zones of growth; it had the characoteristic cedar smell and appeared to be quite suitable for the manufacture of cigar boxes and for veneering purposes. J) uring a subsequent visit to Aburi I was shown a polished plank cut from this tree. The grain was beautiful. Specimens of the wool hare, I understand, been sent to Europe for exhibition. The species up here loses its leaves during the dry season, at which period it bears fruit. The flowers appear in the rains.

I am inclinel to believe that this tree will prove invaluable for re-afforesting the denuded hillsides in the vicinity of Aburi; its rapid growth makes it eminently suitable for this purpose. Its deciduous habit, however, will necessitate subsequent underplanting with some evergreen species if the soil is to be adequately protected during the dry season. This species also thrives at Olokemeji and at Ebuta Metta in the TVestern Province of Southern Nigeria.

It produces great quantities of seed at a comparatively early age. Taken all round it promises to be one of the most useful of exotic timber trees in West Africa.

Casuarina.-This species also does well at Aburi and shows a good growth. It should prove very useful for firewood, for re-afforesting the Accra plains, and for the first stages in creating wind breaks along the exposed sea-coast.

The West Indian and South American mahoganies, Swietenia Mahogani and S. masrophylla are not doing well here. Their growth is poor and is being checked by the attacks of an insect that damages the leading shoots. Similar damage up to a certain age is done to the indigenous Khaya Punchii (a closely related genus) in the Calabar Gardens. Examples of the American species grown at Olokemeji, Western Province, Southeln Nigeria, in a somewhat drier climate suffer in just the same manner from insert attacks. There is one well-growu, healthr-looking Suretenia of moderately large size, however. to be seen in the Ebuta Metta Gardens in Lagos, where the rainfall is much in excess of that at Olokemeji.

The East Indian teak tree (Tectona grandis) has not proved a success in these gardens. The growth is poor for the age of the plants and probably the soil is not suitable for it. At Olokemeji, where there is an impermeable "pan" just below the soil, teak becomes "stag-headed" at a very early age. It shows slightly better growth at Ebuta Metta near Lagos, but I have nowhere in West Africa seen healthy, well-grown specimens of this species. On rich and deep alluvial soils close to the banks of perennial streams, where dense evergreen vegetation is the prevailing type, it will no doubt prove more successful, provided it is protected against crowding out by indigenous plants. Though it is a typical tree of the "mixed deciduous forests" of Burma. I have ocrasionally in some of the moistest evergreen forests of 
that country found numbers of trees growing luxuriantly in rich alluvial "pockets" of soil. Hence, provided it is planted in deep soil, I see no reason why it should not grow well within the evergreen forest belt of West Africa. As far as I am aware. no determined effort has yet been made for the introduction of this tree to the Coast. Any experiments made in this direction are well worth the trouble and expense, as the reward of success will be great.

The Padauk (Pterocarpus indicus). - The only specimen to be seen in the gardens does not look healthy and has not acquired the typical habit.

The same remarks apply to other Indian trees, such as $D a l$ bergia Sissoo and Jalbergia latifolia, specimens of which are growing in the gardens.

In addition to the experimental cultivation of various plants of economic value, much attention has been paid by the Agricultural Department of the Gold Coast to the most suitable methods of preparing the indigenous rubbers, and some fine examples of Funtumia elastica " biscuits" were seen. Research work in connection with the extraction of palm oil from the nuts of the numerous varieties of the oil palm has also been undertaken: several distinct rarieties of that species have apparently been established and their products isolated. The results when published should prove of great value to the palm-oil industry.

A well-arranged Herbarium, containing specimens of a large number of indigenous plants, has been formed, and is very useful to students of the flora of tropical West Africa. The value of the collection is enhanced by the fact that the bulk of the specimens have been named from identifications carried out at the Royal Botanic Gardens, Kew, and that it contains duplicates of a large number of type specimens.

The part played by the Agricultural Department of this Colony in developing the local cocoa industry is well known, and has in itself justified the expenses incurred in the up-keep of the Department. It deserves every encouragement and the most generous treatment at the hands of the Administration. During my visit to Aburi, both the Acting Director of Agriculture and the Curator took every opportunity of helping me in my inquiries concerning the indigenous timber trees and other useful plants of the country. Reports and documents relating to these matters were placed unreserverly at my disposal, and I was helped in every possible war. I take this opportunity of acknowledging my indebtedness to those officer's. and of expressing my thanks for the assistance rendered.

Before leaving Aburi for my return journey to Accra, I was shown the source of the precarious water supply of the former town. The flow of what, a few years back, was a perennial stream affording an ample supply of water has now dwindled down to one or two trickles, and indications are not wanting of the stream running dry in the near future. This scarcity of water has undoubtedly resulted from the diminished supply of moisture in the soil, resulting from the destruction of the furests. 
After a short stay at Accra I left, on the 8th of January, 1908, for Sekondi, by the mail steamer "Burutu," arriving there the next afternoon. Whilst my carriers were being procured, stores purchased, and arrangements being made for a prolonged trip into the forests, I took the opportunity of visiting the saw-mills at Gaiyin Krom, $12 \frac{1}{2}$ miles up the railway line, and of examining the forests in their vicinity.

The vegetation near Sekondi itself is of the mixed deciduous type, with, if anything, a preponderance of evergreens. The rainfall of this place is much below 50 inches a year; to this is due the presence of extensive patches of grass lands a few miles up the railway, and the occurrence there of large numbers of the Daleb palm, Borassus fabelliformis. I also noticed some examples of Dialium guineense, the presence of which is another certain indication of only a moderate rainfall. The hillsides on which farming has been carried out are already in places overgrown with grass, and a continuance of the extensive fellings of the bush, after the native methods of farming, will undoubtedly tend to push the deciduous regetation further inland to places at present occupied by the densest of evergreen forest. The invasion has already started.

If there is any wholesale clearing of the vegetation which clothes the main ridges and borders the more important streams on those portions of the West African coast possessing a medium rainfall of 50 inches and under, there is great danger of permanently reducing the water supply of the country, and of encouraging the spread of deciduous-leafed regetation and, above all, that of the grasses.

During my stay at Sekondi, Messrs. J. R. Nicholas and Brett very kindly gave me much useful information regarding the timber trade of the Colony and the different kinds of wood exported to Europe; they showed me various samples of timber, and marked for me on the maps the distribution of the more important forest areas, both of the Colony and Ashanti. They were also good enough to place their house near the saw-mills at my disposal, to invite me to wander freely all over their iimber concessions, and to supply me with guides and natives familiar with the forests and the regetation; in short, they helped me in every possible way. For all this assistance and kindness I tender my best thanks to those gentlemen.

As one passes up the railway line towards the saw-mills (which are situated alongside the railway at a distance of $12 \frac{1}{2}$ miles from Sekondi), some fairly extensive patches of grassland are met with; they are dotted about with the palm, Borassus flabelliformis, and small clumps of bush containing Vitex cuneatu, Vitex macrophylla, Anona senegalensis, Sarcocephalus esculentus, and other plants typical of the Savannah forests; beyond this comes a belt of mixed deciduous forest much honeycombed with clearings made for the native farms. These fellings are comparatively recent, and have not yet been repeated sufficiently often to convert the existing type of regetation into the open Savannah forests. The clearings are, however, being gradually 
invaded by grass, and the conversion, under present conditions, is but a matter of a few years. This belt of mixed deciduous forests gradually and almost imperceptibly passes, as one proceeds further up the line, into the typical moist evergreen tropical forest (tropical rain forest of Schimper) so common along the West Coast of Africa wherever the rainfall is sufficiently heavy to favour that type of regetation. Gaiyin From (the saw-mills) is situated in the midst of such an evergreen moist forest. The land rises rather abruptly shortly after leaving Sekondi, and then continues with a more or less undulating character up to the saw-mills. The difference in level between Sekondi and this place is, however, slight, and only amounts to a few hundred feet. The saw-mills have been established mainly for the purpose of supplying the mines with converted timber of local origin, but the demands of the larger towns, such as Sekondi and Kumasi, for such produce have not beev overlooked, and every endeavour is being made to satisfy local wants. The mills are fitted with one large circular saw and some small auxiliary ones. They are of a rather antiquated pattern, but appear to serve their purpose fairly well. The bulk of the timber converted is procured from the tree known to the natives as Kaku, a species of Lophira, probably L. procera, the wood of which is hard and extremely durable, more so than any other West African timber. It is especially suited for sleepers, of which large quantities are turned out by the mills, and for underground structures that are exposed to much moisture. Logs of mahogany, cedar, and odoum (Iroko) also are cut up for local use, and occasionally trimmed for export to Europe. The mills no doubt serve a very useful purpose, and should be encouraged. There is great scope out here for the creation of a regular demand for local woods to replace the large quantities of foreign produce imported from Europe. The West African forests contain several excellent species of timber trees that can furnish all that is desired in the way of woods suitable for furniture and other constructive purposes; and it should be possible with proper management to place such woods on the local markets at a less cost than the imported material. Such a demand for local produce would enable several kinds of wood to be utilised on the Coast, woods which, though they do not command a ready sale in Europe, have a good reputation on the West Coast for durability and general usefulness.

Up to the present only a very few of the different species of timber trees composing the West African forests have been exploited for the European market. The balance, which contains several useful kinds, has been practically left untouched. A local trade in the latter would utilise material which is standing wasting in the forests, and render of some value large tracts of forest land that are at present worthless so far as the timber industry is conoermed.

Hitherto, only timber cut from the various species of Khaya (mahoganies), Pseudocedrela (cedars), the N'yankom (Heritiera utilis), Bossè (species of Guarea), and the Pebedum (Lovoa Klaineana), has been exported in any quantities to Europe, gene- 
rally under one or the other of the two comprehensive trade names of "West African Mahogany" and "West African Cedar." A few logs of the Odoum (Chlorophora excelsa), the Baku (Mimusops IJace), and some others have from time to time been sent to Europe, but such shipments have met with scant encouragement in the home markets. It is with a view to creating a demand for these roods, the good properties of which are well recognised and appreciated in West Africa, that efforts should be made to start local markets for them. The markets would, of course, be best fed by the establishment of saw-mills along the main lines of export.

\section{CHAP'TER II.}

\section{The Fonests of the Gaiyin Krom Concession.}

The country in the vicinity of the saw-mills is undulating in character; towards the east some well-defined ridges form the water-parting between the Win and Pra Rivers. The soil consists mainly of clay sands with a good admixture of humus. The soil of the lowest depressions is marshy, and contains a larger percentage of clay. On the higher ridges to the east a fer outerops of quartz occur. The average annual rainfall appears to be about 80 inches, and it is fairly well distributed through the year. The spells of extremely dry weather accompanying the desiccating "Harmattan " winds are of short duration, and do not last long enough to have any permanent effect on the regetation. The latter belongs to the type known to Indian foresters as the moist, evergreen tropical forests, in which the bulk of the plants are hygrophilous, and those with the deciduous habit quite the exception. The forest consists mainly of secondary growth of great age, and towards the east becomes almost primeval in character. The trees there are of immense size. The leaf canopy is almost complete, and the undergrowth thimner than it is in the younger secondary growth close to the railway line. It has been fairly rich in valuable timber trees but the majority of the latter, especially those of exploitable size situated within easy hauling distance of the saw-mills, has now been felled. Light tram lines have recently been constructed to tap the remoter portions of the Concession, and there is no doubt that the lapse of a few more years will see the complete exhaustion of the stock of timber of marketable dimensions. 'The younger secondary forests are dominated by the following trees, placed in descending order of frequency:-

1. The Dahomah (Piptadenia a fricana). One of the commonest trees of the tropical evergreen forests, in which it is universally distributed. In habit it is partially deciduous during the dry season, more especially where it has sprung up on lands that have once been cleared for farms. Quite recently, specimens of the wood exhibited at Liverpool have attracted the attention of some of the timber brokers. If a demand for this timber should ever arise in the home markets, the supply will be found to meet 
almost any calls made on it. The reproduction of this species is very fair, and the age gradations better represented than is usually the case with West African timber trees.

2. The Maw-we of the Fantis (Triplochiton Johnsonii). A fine loftr tree that attains large dimensions. It is found throughout the evergreen and mixed deciduous forests of the Gold Coast and Southern Nigeria, right up to the limits of the open Saramnah forests. It reproduces itself freely by seed, and roung plants spring up in large numbers on recently abandoned farm lands. The age gradations are well represented. The species attains its maximum frequency in the mixed deciduous forests of the country. Like the Dahomah it is one of the few species that appear to be if anything rather faroured by the clearings made in the forests for farming purposes. On abandoned areas of that character, it quickly gains the ascendancy over most of its competitors. It is partially deciduous in its habits, even in the moist forests. In the deciduous type, I hare sometimes noticed it to be almost completely dentuded of leares during the dry season of the rear. The wood is of fine grain, light in colour, and only moderately hard; it is weil suited for the internal fittings to houses, and, in fact, for all purposes where it mould not be exposed too much to rain. It is quite good enough in quality to replace the imported pitch-pine, and it is extremely abundant; our West African forests contain sufficient supplies not only to meet large demands for it in the home markets, but also in the local ones. The tree has an excellent form figure, and carries its girth up well to the first branches.

3. The Assomah of the Fantis (Parkia species). One of the West African locust-bean trees, the pod of which is edible. This species is an evergreen.

4. The Offram tree of the Fantis (a species closely related to Terminalia superba). This is a beautiful straight-stemmed tree of good-form figure, with the branches coming out at right angles to the stem in almost regular whorls. It is flat-topped and has a great range through the forest areas of the Gold Coast. In the mixed deciduous forests, and up to the limits of the Savannah lands, it is deciduous, but in the moister regions it is almost an evergreen. It seeds most copiously, and like the Waw-waw and the Dahomah springs up freely on abandoned farm lands. The rood is light in colour, and as it splits very freely and regularly, it is much used for shingles by the Ashantis and other cognate tribes. The shingles last, on the average, for about seren years. No doubt if tarred they would prove to be much more durable.

5. The Afram of the Fantis (probably a species of Parinarium). A common tree in the moist forests. Grows to a large size, but the mood is light, soft and porous, and almost useless. The fruits are edible.

6. Eriodendron anfractuosum. The Common West African silk-cotton tree, and one of the giants of the moist forests.

i. The Kaliu (Loplira procera). This is the "red iron-wood" tree of Southern Nigeria; the wood is of a deep reddish-brown 
colour, hard and rery durable. The Kakn is a medimm-sized tree, confined to the evergreen forests of the maritime zone, and its northern limit is roughly about the latitude of Dunkwa Station on the railway. It is rely partial to swampy areas, seeds freely, and has the age aratations fairly well represented. It furnishes one of the best fuel woods of West Africa.

8. The Nya-me-dua (Alstomia congensis). This species is also partial to the swamps. The wood is whitish in colonr, soft, and much nsed for the manufacture of native stools. The latex is used for adulterating that of Fumtumin elostira.

9. The Dubini (Khaya sp.). This is the common mahogany of the Gold Coast, and appears to be closely related to Khaya Punchii, of Southern Nigeria. It sometimes attains enormous dimensions, and one huge example was seen on the eastern boundary of the Concession. Like all members of this genus, it exurles a gum from any injuries made on the lower portion of the bole. The bulk of the mahogany shipped from the Gold Coast is procured from this species.

10. The Emril (species of Terminalia) has somewhat the habit of the Offram. The wood is of a yellowish colour, has a pretty wrain, and is mell snited for house boarding and other internal fitting's. It is fairly durable.

In the older forests the species that maintain their dominances are, in descending order of frequency, the silk-cotton tree (Eriodendron anfractuosum), the above-mentioned Dahomah (Piptadenia africana); the Kalin (Lophira procera), in swampy and moist localities: the II aw'-waw (Triplochiton Johnsonii) on higher ground; the Offram (Terminalia superba): the Gold Coast mahogany, Dubini of the Fantis (species rlose to Khaya Punchii) ; the Batiu (Mimusops Mjare), which occasionally grows to an enormous size and yields an excellent wood; the Kolioti (Pynaertin ealaensis), another good timber tree that also yiclds a first-class fuel; the P'unliua (P.seudocedrela cylindrica), which produces the bulk of the cedar shipped to Europe; the Oiloum (Chlorophora ercelsa), that furnishes the most useful mood in West Africa; the oil-bean tree, Athawah of the Fantis (Pentaclethra macrophylla), the seeds of which are rich in regetable fats; the Ote (a species of Myristica); the Lissia (Combretum species): the Asomah (Partia species); and the redflowered silk-cotton tree (Bombar buonopozense).

Among the rarer trees the following species rere noticed:

The Kishia (Sareoceplatus esculentus), the timber of which is of a bright yellowish colour, hard and rery durablethis species attains a large size in these moist forests, but further inland, in the dry Sarannah forests, it acquires the habit of a shrub; the Bimmi (Jetarim species), a good timber tree of lofty dimensions: the Awama (Ricimodendron africanus), the seeds of which are rich in oil: Tetraplenra Thommingii, with edible fruit: and Antiaris toricaria var. africana, a large tree, the bast fibres of which are beaten out to form a native cloth. 
Amongst the smaller-sized trees the following species occur in these forests:- -

Bertiniar acuminata: Musanga Smithii: Myrianthus arborens; Jonodora myristica: Monodora tenuifolia; the Afona (not identified botani('ally): the Apurro, also not identified; Toaconya ofricana; and Rianmolfur romitoria.

Scandent palms, such as species of Colomos and Ancistrophyllam and rubber vines such as Landolphia Kilanci and Carpodinus hirsuta, are the most comspicuous liames to be seen climbing orer the tous of the trees, whilst the feebler and more succulent plants of a similar habit are represented by climbing aroids of the genera Culcusin, Cercestis. and Raphidophora, which, howerer, confiue theil attentions to the stems and larger branches of the trees. Various epiphytic orchids, such as species of $A$ grocum, Mcgnctinmm, \&c., and ferns of the genera Asplenium and Platycerimm are also noticeable features of the regetation.

\section{Sump Tegetation.}

Is a rule, the depressions and low ralleys in the Gaivin Krom Concession are marshy, and such areas are inhahited by species characteristic of fresh-water swamps. Amongst others, the trees are represented by the Baya (Mitrongyne macrophy/lo), the wood of which has oceasionally been shipped home to Europe as " West African mahogany"; the Kalil (Lophira procera) along the edpes of the swamps: Lacrolobium P'alisoti, with a hard red wood: the Nya-me-dun (Alstomia comgensis), the soft wood of which is used by the Ashanti and "ognate tribes for the manufacture of native stools and the latex for adulterating that of the silk rubber tree (Funtumio elastica); the screw pine (Pandanus candelobrmm): the bamboo-or. Tombo - palm (Raphia rinifera); ('alamur. Barteri; Sorcocephahos Rasseggeri; and Anthocleista mobitis.

\section{Tegetotion on clearings.}

The plants that spring up on very recently abandoned clearings such as those along the telemaph line and both sides of the railway consist, in addition to seedlings and coppice shoots of the more dominant trees, mainly of shrubly and herbaceous species, some of which, howerer, attain the dimensions of small trees. The most romspicuous of the latter" is the " umbrella tres" (.Musmmga Simithii) of European residents on the Gold Coast. This species is extremely prolific and rapidly occupies such aleas: others ale the lare Termonio frondose, I/yrianthus arboreus and Ilaromga madryasermiensis.

The shrubby and herbaceous regetation is represented

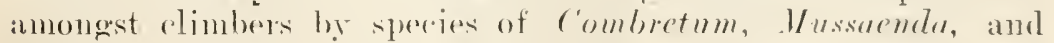

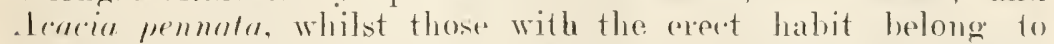
the genera 1 morplophallus. Lenlyphas, c'rotalaria, Bidens, 
Ayeratum, IIelichrysum, Achyranthes, Aerua, and to fibreyiclding weeds such as species of Urena and Triumfetta.

As regards the natural replacenent of the timber trees and other plants of economic importance. I found that of the Offram, Waw-uaw, Kaku, and Dahomah to be excellent. The mahoganies and cedars, though they seed freely, are not so surcessful, as, owing to the dense undergrowth, the seedlings are choked, and comparatively few reach the sapling stage. The same dificulty occurs in the case of that fine timber tree, the Baku. Where clearings have been made by felling trees in the vicinity of the older cedars and mahoganies during the ordinary course of exploitation and along the dragging paths, quite a lot of seedling's of these two species spring up, and, if the elearings are kept open for two or three seasons, as they frequently are in the case of some of the main hauling roads, a fairly large proportion get a sufticiently good start to enable them to hold their own with other species in the struggle for light.

The density of stock of the different species is very variable, being as high as two to three trees per acre in the case of the trees mentioned as possessing excellent natural regeneration, and as low as .25 to .1, approxinately, in the case of the mahoganies and cedars. The above estimates are only rough approximations, and are useful more for showing the proportions in which the different species oceur than as a basis for calculating the quantity of growing stock. For the latter many more surveys in greater detail are needed: the time at my disposal was far too short to admit of such operations being carried out. The above figures, however, are sufficiently acculate for the purposes of rough estimates.

\section{The Age Gradutions.}

Taken as a whole, these are not well represented, especially in the case of the most valuable timber trees. Whole classes are often missing, and the most frequelit gaps oecur between saplings and trees of medium age. The mahoganies and celars are usually worse off in this respect than the less useful species.

Amongst the dominant kinds, trees such as the ffrur-var, the Kaku, the Dahomah, and the Offram have their age classes fairly well represented; but even iii their cases the gradations are uneven and imporiant gaps often vccur. In the older forests the bulk of the arboreal growing stock is orer-mature and regeneration fellings, carried out with considerable care and judgment, will be necessary before the forests can be transposed into anything like the normal type.

The younger forests are rather better off in this respect, but the whingale felling of the regrtation for farming purposes has generally resulted in favouring species that do not at. present happen to be of much economic importance. The struggle for doninance amougst the members that spring up 
on recently abandoned farm lands is intense, and the victory falls to the lot of comparatively few species, such as the $\mathbb{H}$ auwar, the Offram, the Arama, and the Kalu, the first and second of which appear to be specially ardapted for quickly gaining the mastery over their competitors. As a rule, owing to the practice of the natives of grubbing up and burning the roots of the large trees felled on the sites of the more carefully farmed areas, the proportion amongst the individuals forming the secondary growth (that springs up when the farm lands are allowed to become fallow) of those that have originated from coppice shoots is not so large as one would expect; quite a respectable number have their origin from seeds blown on to the cleariugs fiom trees in the adjacent woods.

Three out of the four species 'mentioned above as being most successful in the "struggle for existence" on recently abandoned farm lands possess winged seeds that are sufficiently bulky and heavy to enable them to reach the ground through the usual dense growth of weeds that spring up on such areas. The fourth species, the exception, is the Aurma (Ricinoden(ron africamus); its fruits are eagerly sought after by frugivorous bats, but I have not ret been able to settle definitely the question as to whether the fruits are raried a suficient distance by these mammals and then dropped or not. That they do occasionally carry the fruits and drop them a short distance from the trees is certain. Perhaps the reasons for the dominance of the dwama are to be sought for elsewhere. Another point that farours these dominant species is their rapid growth when young; this, coupled with the excellent dispersal of the seeds and the ability of the latter to reach the soil quickly, enables the plants to occupy new clearings promptly.

\section{Enema Krom Concession.}

T'o the west of the railway line, Mr. Higginbotham, the owner of the saw-mills, possesses another concession, in which he has starterl a small rubber and cocoa plantation. The forests in this direction are of much the same type as those growing to the east of the railway, and, if anything. are of more recent origin. The area has apparently been subjected to heavier fellings in the past for farming purposes than the Gairin Krom block.

The dominant trees here are Mahomah, Offram, Thaw-wax, and the Assomah (Parkia species). A few exceptionally wellgrown Odomms (chlorophora cacelsa) were seen, and one rare species, the Pebedoum (Lovoa Klainerma), was found hy me for the first time. The wood of this tree is excellent; it much resembles teak, and has been shipped home to Europe by Apollonian timber merchants of the Axim district. 'The example seen by me was of an exceptionally large size and towered over the rest of the forest trees.

The portion of the concession gone over was rather drier than the block lying to the east of the railway, and a species of 
Albizia, probably A. rhombifolia, not seen in the Gaigin Krom, occurs here. This species is rather partial to the drier portions of the moist forests, and, with some others of the same genus, is much more plentiful in the forests further north, where a larger proportion of trees with the deciduous habit are to be found.

South-east of the saw-mill, along the old road to shama and close to the site of Nicholas Krom, the forest is rery old and contains some trees of lofty growth and a large girth. Some fine eximples of the Koloti (Pynaertia ealacnsis) were shown to me by Mr. Brett in this forest, where we also noticed a fair number of the ordinary Gold C'oast mahogany (Khaya sper.ies), the Odoum and the Kaku. Very large examples of the Baku and the ordinary silk-cotton tree (Eriodendron anfractuosum) are found here and there, and the undergrowth in such places is not so thick and tangled as it is in the younger secondary forests. The rubber-yielding vine, Landolphia Klaine is quite common; its huge globular fruit, almost the size of a man's head, were often found lying about the path.

Close to the banks of a fairly large perennial stream the vegetation is very fine, and is a typical example of a Tropical Evergreen High Forest, or, as Dr. A. F. Wr. Schimper calls it, a "Tropical Rain Forest" of West Africa. 'The forest in question is bathed in the same humid atmosphere, containing trees of lofty growth connected one with another by lianes and a perfect network of smaller climbers; the stems are covered with epiphytes of various descriptions, and under all the same dense gloomy shade with its tangled rundergrowth prevails as in the type.

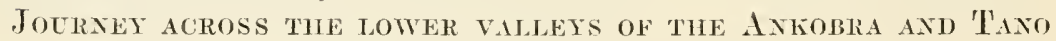
RIVERS THROCGH THE Districts OF LOWER WASSAW, UPPER WASSAW, LOWER DENKIRA, AND THENCE BACK TO THE RAYLWAY LINE AT DUNKWA.

The carriers engaged for me having arived, I proceeded on the 20th of January by rail to larkwa, where I met Mr. K. Burbridge, Curator of the Gardens, who had been instructed to accompany me during my journeys through the Gold Coast forests. One lay was taken up in completing arlangements, and we left that place on the $2:$ nd for an extended tour through the Wassaw and Lower Denkira districts in directions which I hoped would enable us to form a fair estimate of the value and extent of the forests chothing the lower and middle drainage areas of the Tano and Ankobra rivers.

Before describing that journey in detail, I may remark that the railwa-line between the saw-mills and Tarkwa passes thromoln moint evergreen tropical forest the whole way, and that the rountry is libly and well watered-most of the valleys being orempied rifher by peremnial streams or fresh-water swamps.

In the moinhlowrhoml of the more important villages such as Ifansu and Isuaso extensive charings have been made for farms, the abandoned sites of which are now mainly occupied by the 
"umbrella tree" (IMusanga S'mithii), the Mahomah, II aw-una and the Offram, which with other species form the irregular, patchy, high forest so characteristic of this secondary growth. Steep hills are not usually selected as sites for farms by the natives when gentler slopes covered with sufficient regetation are arailable; where they occur the forests clothing them are of much greater age and frequently approach the virgin type.

Laroge numbers of undersized mahogany and cedar logs were seen lying along the sides of the railway and in the bed of the Bonsa River where the line crosses it. These logs are mainly rejections that the European timber merchants have, on account of the small dimensions of the timber, refused to puichase from the native contractors and owners. It is a pity that such logs which are not worth exporting to Europe should be allowed to be wasted in this manner. It would surely pay to send them down the line to the sin-mills, where they could be converted into pieces suitable for the tonstruction of furniture, Sc. Perhaps the railway freights are too high to admit of such a use being" made of them. Though undersized for the European market the logs are quite suitable for local constructive works. The action of the European timber merchants in rejecting such timber is having al salutary effect on the native fellers, who are beginning to realize that it does not pay to cut undersized trees. This fact, however, in itself is not sufficient to protect immature trees and does not do away with the necessity for fixing by legislation minimum felling girths for the various species.

Fairly extensive clearings of the forests are to be seen round the majority of the rold mines situated in the neighbourhood of Tarkwa. The bulk of the fellings have been made in order to supply fuel for the machinery employed in them, though of course a great deal had to be also done in clearing sites for the minimg camps. As a general rule the cleared areas first get covered over with a dense growth of the "umbrella tree" and the usual tropical weeds that spring up ou such spots. These vlants are in turn gradually replaced by forest regetation, but the process, owing to the luxuriant growth and persistence of Musanga Smithii, is a slow ome. Fortunately this species is an evergreen, and its dense foliage affords sufficient protection to the soil to prevent the usual injurions effects following the direct exposme of the former to a tropical sum. Tevertheless such fellings if repeated at too frecpent intervals (short felling rotation.) are liable to be followed in the tropics by marked effects on the climate. and they should in such cases be only carried out under professional superrision. I have dealt with the question of the fuel supply for the mines in some detail in another part of the report.

Reverting now to our journeys through the forests clothing the basins of the Ankobra and Tano Rivers the first day's march was made to the small village of Hunisu situated on the Huni River, and on the main road between Tarkw and the mining camps of Prestea. The comutry in this dinection is rery hilly, and some well-marked ranges belonging to the systens forming the eastern and western water-partings of the Huni River have to 
bo crossed. Between l'arkwa and Hunisu most of the valleys have either perennial streams running down them or are occupied with fresh-water swamps which no doubt drain into the main river during the flood season. The land is thus extremely well watered and it is quite the exception to come across dry beds of waterourses. The rainfall also appears to be heary judging from the character of the vegetation, which belougs to the moist 'Tropical Evergreen ("Tropical Rain Forest" of Schimper) and 'ropical Fresh-Water Swamp types of forest. Here the former as a rule consists of irregular, secondary high forest that appears to have sprung up on areas that were once cleared of regetation very many years ago, a period amounting on the average to sereral generations. All stages, from land but recently reoccupied by forests to that of older growth, are to be met with and their comparative ages can, apart from the size of the ordinary forest trees, be fairly well ascertained by the relative abundance and extent of the patches of pare Musangn smithii forest that they contain. Nevertheless in a few places here and there forests of a really great age are to be met with, and these approach closely to the primeval type.

One day was devoted to making a rough analysis of the growing stock of the forests in the neighbourhood of Hunisu.

The forests themselves are in all essentials similar to those growing in the vicinity of the saw-mills and are, if anything, rather moister in character, especially those passed through during the first two hours of the journey to Hunisu. The presence of numerous tree ferns along this part of the journey confirms the existence of great humidity in the locality.

Of the most valuable timber trees such as the mahoganies (species of Khoya) and cedars (species of Pseudocedrela) but few were seen, and the forests are distinctly poor so far as they are concerned. Other useful timber trees, howerer, are much more plentiful. Examples of the Nyankon (Heritiera utilis) a new species that vields a rery fine wood similar to that of Khaya, the Kirku, the Odoum, the Buku, the Kishia (Sarcocephalus csculcntus), the Kokoti, and the Dahomah were seen: the last species as usual is the most dominant. Curious to say the other markedly dominant trees such as the Waw-waw and the Offram, which are very characteristic of the evergreen tropical forests, were comparatively scarce in this neighbourhood, and I am inclined to think that those two species are not at their optimum in excessively moist forests such as these are.

The less valuable species, so far as timber alone is concerned, were represented amongst a host of others by the Simanta (Sylia Evansii), another new species; the Baya; Macrolobium Palisotii; Pentaclethra marrophylla, the seeds of which, however, are rich in regetable oil; the Asomah. (spercies of Parkia) which is rare: the N'Kotan (an undermentioned spercies), from the wood of which the chareoal used by the native goldsmiths is prepared. This small tree is partial to swampr localities and is supported on long aerial roots " Prop roots" of Schimper); the Abotoasibi. (species of Gurcinice, also fond of swampy soils, and the Okisibiri (a species not ret identi- 
fied for want of specimens of the flowers), the timber of which is called the "flint mood" by the European miners, and is excessively hard. It is used for mine props, and is said to be very durable and immune to the attacks of termites (" white ants"). 'This small tree only grows on high well-drained land and is never, as fir as I know, found in the moist hollows close to streams. The swampy areas are inhabited by the same species mentioned before as composing the fresh-water swamp forests found in the neighbourhood of the sam-mills at Gaiyin Krom. The cosmopolitan silk cotton tree is of course found erel'rwhere, and forms a conspicuous feature of most TI est African landscapes.

'The Huni hiver, close to the ferry opposite the village, has some fairly deep pools that are crowded with a beautiful white flowered lily-like Amaryllid, Crinum nutans. 'There is also a fine specimen of the Baku tree (Mimusops Jjace) to be seen on the left bank close to the place where the main road crosses the stream.

The next march was from Hunisu to Prestea. 'L'his again was across very broken country intersected by two fairly high ranges of lills that are clothed with rather dense evergreen tropical forests. Forests of secondary growth and of comparatively recent age are. howerer, the prevailing forms to be met with, especially along the roadside in the ricinity of the present villages or their old abandoned sites. The oil palm, which has up to this point apparently been scarce, now makes its appearance for the first time in somewhat large numbers, but it does not seem to be anything like as fine a tree as it is in some parts of Southern Nigeria. Cedars are far from rare on the higher ridges and a few examples of the ordinary Dubini were also seen. The descent from the Water-parting between the Ankobra River and its feeder, the Huni, to the banks of the former is rather abrupt, and ends in rery swampy ground, probably reduced to that condition by the overflow from the river. Before the final descent is made the water-parting assumes a somewhat terraced formation, the nariow plateau-like steps of which are usually rery moist and give rise to numerous small feeders of the Huni and Ankobra Rivers. Some luge examples of the Baku were seen about here as well as fine specimens of the Odoum. After crossing the Ankobra kiver. which at this, the lower. ford, is a fair sized stream with a sandy bottom and high, steep banks, a stiff climb brought us to the crest of the range on one of the lower westem spurs of which the mines are situated. Near the top of the ridge I noticed sone nore redars, Pseudoredreln cylindrica. a new speries, and examples of the grum copal tree (Cyunothyrsus ogeu): a very large species of Piptadenia, and an apparently new species of Brachystegia, of elegant proportions. The forest about here appeared to me to be somewhat drier than those we had lately come through, otherwise it is very similar to the vegetation found near Hunisu, and only differs in minor details such as the relative proportions in which the different species are found growing together and in the appearance of a few others not seen in the forests previously examined. 'The Awama (Ricinodendron africanus), for instance, 
is more plentiful about hele than it is at Hunisu, and so is the II $u x-u(u x$.

We spent a day at Prestea in order to ascertain the character of the fellings made for supplying the mines with fuel. For this purpose we walked along the light tramway-line, leading to Fura Junction, for a few miles in that direction. The felling zone is limited to about 500 yards on either side of the line, which is utilised as the main haulage track. We found that the bulk of the arboreal regetation had been cut within this zone with the exception of the following species, the wood of which has been found to be difficult to split into billets, and has therefore been discarded by the native contractor's who supply the mines with fuel.

The favoured species are:-

The Dahomah (Piptadenia africanu).

the Athawah (P'entaclethra macrophylla).

I species of Brachystegia.

A species of Dialium.

Uf these the first two are the most important, as one of them, the Athawah, is the oil bean tree, and the other, judging from recent inquiries made at home about the rood, is likely to turn out a useful timber tree.

All other species of arboreal habit have been felled, including Khayas, Pseudocedrelas, the Kuku, the Baku, Kolooti, Kishia, Offrum, Emril, \&e.

T'hose that have from experience been found to be the best for heating purposes are, in descending order of merit, the $K a k u$, the Kokoti, the Baku, Dubini (Khaya), Nyankon, \&e.

Some exceptionally fine pieces of timber from the latter species that had been split up as firewood were seen. The wood is very similar to that of the mahogany (Khaya), and has the same brilliant lustre along the radially fractured planes, due to the conspicuous "silvery grain" of the medullary rays as seen in that section. "Nituated as those mines are, a rery long distance from any sea-port, the general use of coal would on account of the expense of transport be prohibitive, and under these circumstances the only alternative is to utilise the fuel obtained locally from the forests. 'The cost of obtaining this even is prohibitive, unless (with the exception of the wools that are difficult to split) every species standing in the forests can be cut up and used for firewood. Any attempt in these areas at trying to potect valuable speeies such as the Dubini, Kaku, Baku, Kokoti, $\mathbb{E}(\cdot$., simply means that the balance of the arboreal regetation would not be worth exploiting for fuel. for these trees possess the grood calorific properties, and they form the main mass of the regetation. It so happens that the verr timbers that are most useful for export and for lowal purposes are also best for fuel. Junt under thene circumstances it would be folly to place any restrictions on the cutting of the forests for fuel: such restrietions would and in stiffing the gold-minine industre in inderessible localities where it is alveady diffeult enough to make the revenue balance the expenditure. Tu my opinion only two conditions should he allowed under the present condition of the 
wold mining industry to dotermine any such restrictions: these are the signs of a change in the climate (water smply) towards at drier condition or a marked denudation of the hillsides. Of these two the former is by far the greater danger to be gruarded against, and at the first symptoms of such a change oceuring the fellings should be placed under the control of a Forest Department. Lortunately in the "Embrella tree" (Musanga smithii), however troublesome a plant it may be when competing" against the growth of more valuable timber trees, we possess a species of extraordinarily rapid growth and strong dominance that quickly and eftectually occupies cleared areas, and with the help of the dense shade cast by its foliage affords ample protection to the soil against the action of the sun and of desiccating winds. In the ricinity of the Prestea mines whole hillsides that have been denuded of tree growth are now clothed with pure, dense patches of that species, and providing such cover is not removed at too frequent intervals, as would be the case if the felling rotation was a short one, there is but little danger of any marked eftect being produced on the climate, especially as the locality in question is surrounded by tropical evergreen high forest and is far removed from any arid tracts of country. As the question of a cheap fuel is of vital importance to the mines, the felling of valuable timber trees for that purpose, especially when the timber they rield happens to be the best in heating properties, should be considered, so far as the interests of the timber trade are concerned, as of but small importance. After all, the use of timber for fuel is a well-recognised one, and whole forests are systematically exploited for that purpose. It is simply a question of local conrenience, and to which purpose the product of the trees happens at any particular place to be of the most value. But for whatever purpose the forests are exploited they should, as far as possible, be placed under the treatment that best ensures the objects in view and prorides for a contimuous supply of produce. With this important principle in mind there is but one condition at present that I would insist on when the forests are being exploited for fuel, and that is that the stems of the trees should, wherever possible, be felled flush with the ground so as to promote the regeneration of the forests by means of coppice shoots which this method of eutting farours. Of course in the case of trees provided with large buttresses the fellings will have to be made at a greater height from the ground, above the point where the buttresses merge into the stem, otherwise the expense and time taken up in cutting through the former would be prohibitive. However, whenever it is possible to do so. the felling of the timber flush with the gromnd should be insisted upon. Fren in the case of buttressed stems, when once cut through, the subsequent felling of the large coppice shoots that spring up from the stumps will present no further difficulty as they will in general not he furnished with huttresses or possess only feebly developed ones when cut at that age. Turler this system the expense of cutting through the buttresses will be incurred nnce for all and will not be recurrent.

Where large timber is also in demand, as it is at most of the mines, the ideal system of managing the forests is that knomn 
technically as the method of "coppice with standards," which provides both for fuel and large timber, or an alternative method, and one which would perhaps be simpler, would be to set aside certain areas for the production of large timber and exploit the balance for fuel under the simple "coppice" methor. Whicherer system is arlopted the "working plan" for the same should be drawn up by the Forestry Department, the members of which wonld explain its provisions to the mining authorities concerned and help them in carrying it out by general advice and supervision.

I understand that the mining leases in most instances carry with then the light to all timber growing on the land, and it is a moot point as to what amount of control, if any, Government can exercise over the fellings on such property. There is one point, however, in this connection that is universally recognised and acted upon in all European countries, and that is the right of the state to control any acts that by excessive or improper exploitation of the forests or by their destruction imperil the climatic factors of the country, or, as in the cases of avalanches and landslips, the life and property of the inhabitants. To this extent, then, I imagine Government could interfere should occasion arise with the exploitation of the forests growing on areas leased to the mining companies. I do not, however, anticipats any difficulty in getting the mining pcople to adopt simple and inexpensive methods of exploiting the forests under their control, provided they are helped by the adrice of the professional Government foresters. I think they will readily accept such advice if it is given in a proper spirit and not forced upon them in the form of rules and ordinances.

This system of the exercise of the very lightest control is, however, only possible as long as the climatic factors of the mining localities do not alter for the worse; as soon as the first signs of such a change are observed it will be necessary for Government to exercise greater authority over the methods under which the forests are being exploited. The construction of more railways (one is alleady being built to the Prestea group of mines), and the general improvement of lines of communication which will no doubt become established facts during the next few vears, will probably relicre the pressure on the forests as sources of fuel, and cuable other substances to replace nood for that purpose long before any marked effects on the climate and soil can be experienced.

I have written at some length on this question of the fuel supply for the mines as the latter represent a very important industry of the country, and it is adrisable that their development should be hampered as little as possible by vexatious interferences in the form of forest legislation. Some of the mine managcrs are alicady considering the advisability of planting up cleared areas with valuable species of rubber-yielding plants and with cocoa. This is an excellent idea, and if followed out should prove of great pecuniary benefit to the companies, as the initial expense of clearing the areas of tree regetation, which is always the greatest expense to be incurred in such ventures, has already 
been borne under the heading of cost of fuel, and the same felling operations will then serve two purposes instead of only one. Such planting operations should, howerer, if they are expected to help towards the protection of the soil against exposure, be undertaken with species with the evergreen habit and not alone with those that drop their leares in the hottest and driest season of the rear, as is unfortunately the case with the Para rubber plant (Heveu brasiliensis), one of the quickest growing, hardiest, and best rubber producers known. 'This species has the deciduous habit most pronouncer when growing in localities having a well - marker! and prolonged dry season. Nevertheless if grown in mixtures with cocoa (cocoa as the "underwood" and Para as the "overwood") a sufficient protertion should be afforded the soil by the dense sharle cast by the latter. 'The Para rubher trees are ouly bare of leaves for a short period each year.

The land at the disposal of the mines is, generally speaking, sufficiently extensive to permit of a long felling rotation, and in conseruence the secondary growth has time to reach good dimensions before it is again removel. This is not the case with the farming rotations usually adopted by the natives, who return to the same area in periods varying from three to nine years, and the secondary growth has therefore insufticient time for attaining a large size. Hence, looked at from the worst point of view, the dangers following the cutting of the forests near the mines for firewond are nothing like as great as in the case of the much more extensive areas utilised by the native farmers. Their operations, for the reason indicated above, are much more iikely to, and actually do, adversely affect the climate and the soil. If by the discovery of new gold fields the mines ever become so numerous as to involve extensive and continuous tracts of country, then the consequences of felling in a haphazard manner every year such large blocks of forest would be more serious, and the fellings would have to he regulated by Government.

After leaving Prestea we proceeded ria Bromase to Ahirisu, on the Mansi stream, a feeder of the Inkobra River, thence to the village of Nikwansia, on the latter, and from there to the valley of the Sibiri stream, a feeder of the same river. Another long day's march westwards brought us into the drainage area of the large and important Tano River. Sereral days were spent in systematically exploring and analysing the forest vegetation of the Ankobra River. and as it is more convenient to describe the forests in groups according to the drainage systems occupied by them, I will hegin hy giving a slort sketch of those found in the Ankobra basin.

\section{Forest Tegetation of the Contral Portions of the Antiobre Drainage.}

The character of the country and the type of forest vegetation clothing that portion of the inkohra drainage situated hetween Tarkwa and Prestea has already been described. The remaining tracts examined lie to the nortl of the latter settlement, and 
extent in that dinection as far as the village of $\mathrm{N}$ Kansia, and after that in a north-westerly direction as far as the 'TanoAnkobra water-parting.

Jetwern the Prestral mining campl and the adjacent group of the Bromase mines the country continues to be hilly and the forest regetation has been extensively cleared for firewood and for the farms from which the food supply of the native settlenents romnected with the mining industry is procured. The lescent to the Ankobra River, which separates the two groups of mines, is rocky and ahrupt, and its channel is much obstructed by huge outcrops of rock; the crossing is very different in character to the lower one, where the bed of the river is covered with sands and grarel and the water quite shallow. Prestea and Bromase are connected by a light tram-line, which is, however, interrupted at the crossing, but an orerhead wire enables bundles of fuel to be slung over from one side to the other without difficulty.

Extensive and dense patches of the " umbrella tree " (Wusanga Simithii) have completely covered the clearings made for firewookl. As the locality is extremely well watered and appears to possess a heary rainfall there is not much danger of marked climatic changes being brought about in the near future by this lestrurtion of the forests. Some saw-pits in which mahogany and odoum timber had been cut up were seen, as well as large numbers of fagents procured from the $N$ 'yankon (Heritiera utilis).

Shortly after leaving Bromase a stiff hill is encountered, after which the path follows the ridge for a lomg distance. 'This ridge is clothed for the greater part of the way with evergreen tropical high forest in which numerous examples of the Dathomah, the T'yankon, the Traw-raw, the TirmaTiama (a new species of Pseudocedrela, close to P. cylindrica), a fine large tree, and a few Dubini (the ordinary Khaya of the moist forests of the Gold Coast) are to be seen. The Odoum (Chlorophore excelsa) is also far from uncommon on this ridge and attains an exceptionally good growth.

on appoaching the ricinity of some native villages situated in the valley to the left of the ridge the forests on. the latter give place to recent secondary growth that has sprung up on the old abandoned farms of the inhabitants. Some quite fresh clearings still occupied by food crops were also seen. From a cleared point on the ridge an extensive riew to the west of the valley of the Ankobra and the broken country through which it flows is obtained, and some conception can be thus formed of the extent to which the forest regetation has been removed by the clearings made for farms. The whole country in that dipection is literally loneycomber with them, and ret the villages are not numerous and the locality is far from heing densely populated.

This moblem of how to cope with and restrict the enormous (comparatively speaking) extent of country that is heing continuously brought under the treatment of shifting cultivation 
is one of the most difficult ones that we have to face. Given sufficient time and a corresponding increase of population (which latter may be confidently expected under British rule), there is not the slightest doubt that slowly but surely the climatic factors will be altered for the worse. When a marked change has been effected and the grasses have obtained the upper hand, xerophilous conditions established, and the annual fires characteristic of such regions are in full sway, then good-bye to all those vegetable products the cultivation of which is so dependent on the heavy rainfall and conditions of growth usually associated with the luxuriant regetation of the moist tropics. Agriculture is of the very first importance to man, but in practising it it is essential to employ only such methods as ensure a continuance of the fertility of the soil and of the conditions regulating the growth of the particular crops cultivated. To deviate from this ideal for any prolonged period results in so altering the conditions as to preclude the cultivation of the very crops that it is intended to maintain. The system adopted by the natives of the country is to clear the land of forest growth, cultivate it for one or two years, and then abandon the area for a new one, where the process is repeated, and so on till five to nine rears have elapsed, when a return is made to the plot first cultivated; the young forest regetation that has in the meanwhile sprung up on this land is then cleared, crops planted. and the whole process repeated, each area being in its turn placed under cultivation for one or two years and allowed to lie fallow for from five to nine years, as the case may be. If the people deroted their attentions to the same group of areas the danger done would not be so great, though the ststem would still be a very wasteful one compared with more recent methods of permanent and intensive cultivation. But this is not all; a further complication ensues from the habit the natives have of continually moving the sites of their farming villages as the soil gradually gets exhausted, and of taking up entirely fresh areas, covered with high forest, for cultivation. The result is that large tracks of forest-covered country, quite out of proportion to the inhabitants they have to support, become involved in the general process of destruction. and this is brought about by quite a small population. The irregular patchy condition of the evergreen forests of tropiral West Africa is due to these causes; and, where the process has been continuous without any long breaks interrening, ther are becoming modified into the mixed deciduous type which is the index of a drier climate, and the forerunner, given a persistence of the same causes, of the far worse conditions favoured by a more pronounced xerophilous regetation.

What has hitherto saved the forests as a whole from almost complete transformation into the last two types mentioned, is the fact that in the past comparatively few areas have, on account of internecine warfare, tribal inrasions, disease, and other causes tending to keep the density of population at a low figure, been subjected to the continuous influence of the modifying 
causes. Large tracts of country have become depopulated, and on such areas the forests have had a chance of effectively reoccupying the soil before any great damage was done. Such ill-effects are of course negligible on areas where the monsoon currents are very pronounced, but as soon as the annual rainfall approaches anywhere near the 50 -inch limit danger is to be apprehended.

Forests, so far as direct observations go, appear to have no very marked effects on the quantity of rain precipitated orer areas covered by them, though their influence is more pronomnced in the tropics than it is in temperate latitudes; but their action on the soil by protecting it against exposure to sun, to desiccating winds and to the action of torrential rain, and in preserving the moisture it contains and thus sustaining and regulating the water supply of the country, as well as in bringing about a high relative humidity of the atmosphere in their neighbourhood, is of the first importance to plants dependent on such conditions of the soil and climate. An abundant rainfall is practically useless to hygrophilous plants demanding a large supply of moisture both in the soil and air if the former is rendered incapable by prolonged exposure of holding in suspension the requisite supply for that type of vegetation. It is this fact that explains the gradual modifications going on in the forests subjected to the reckless destruction caused by the natives. The Government of India long ago recognized the dangers following the practice of shifting methods of cultivation, and had in some instances to restrict its application by suitable legislation. The introduction of such measures in West Africa is urgently called for if the water supply of the country and other climatic factors are to be preserved. Till land is actually required for cultivation (under modern systems of agriculture and not the wasteful methods of the natives) there is no better way of preserving its fertility and even improving it than to keep it under dense forest growth; moreover, the portion actually taken up for agriculture should be thoroughly developed and not abandoned after a short period for another piece of forest land and so on, thus involving an unnecessarily large extent of forest in wasteful destruction.

After descending to the village of Dumanase one comes on to a low, well-watered plateau, the forests in the ricinity of which have been cleared for cultivation. Here we came across small nurseries of cocoa plants, a feature that we subsequently found to he common to all the villages we passed through.

The oil palm is fairly plentiful about here. The forest is excessively moist, and, as usual in such cases, tree ferns reappear on the scene. The arboreal vegetation is mainly composed of Triploctiton Johmsonii, Ricinollendron africanus, A7stonia congensis, Pentaclethra macrophylla, and a few Offrams (Terminatia supertan) and Pseudocedrclas. Portions of the forest, caperially where the platean ends and the land rises up into the 
hills situated between the village and the Mansi River, are distinctly good. Here some examples of a new species of Piptadenia (the Okan of the Benin people) that attains large dimensions were seen. The country is much honeycombed with native gold-diggings, and when moving about in the dense forest growth one has to keep a sharp look-out to avoid falling into the pits.

That portion of the Mansi River drainage which is situated on the left bank is occupied by some very valuable forests that are rich in all the species of timber trees usually. exploited for the Luropean markets. The species represented are, of course, only those that inhabit the moist tropical evergreen forests of the country and do not include the fine timber trees, species of Khaya (mahogany) and Pseudocedrela (cedar), that are limited in their distribution to the drier, mixed deciduous forests found further north. The woods of the latter have, as far as I an aware, never been shipped to the home markets, as the species occupy tracts of country that have not yet been exploited.

Practically the whole of the forest belts about here that are situated within a limit of two or three miles on either side of the Ankobra River and its main feeders, such as the Mansi, have been leased to Europeans and native timber merchants by the chiefs. The particularly fine patch of forest extending from the village of Ahirisu, on the left bank of the Mansi, for several miles up stream on that side, lias been leased to an Apollonian timber merchant, named Mensa, who resides in Axim. His local representative, a native of the same place, is a most intelligent person who possesses an extensive knowledge of the timber trees of the country. He took us about various parts of the concession, showed us the areas where most of the fellings have been made, gave us much information regarding the different species that are being exploited, and generally helped us in every way possible.

In addition to the comparative richness of this tract of country in species of economic importance, the most noticeable feature about it is the excellent natural regeneration of those trees and the satisfactory condition of their age gradations. The latter, of course, is really not very good, but it is far better than one usually comes across in West African forests. For these reasons I strongly recommend the bulk of the forests in the Mansi drainage being taken up as forest reserves after the present leases expire, if it is not possible to do so before.

The soil in this forest is rich, contains a fair amount of moisture, and is capable of supporting trees of lofty growth. The Parkias to be met with about here are quite the tallest and largest I have ever seen. The same holds good with regard to other species, such as the Biunwè (Detarium species), the Bossè (Gaurea species), and the Chen-Chen (Antiaris toxicaria var. africana). The cedars and mahoganies also attain large dimensions and, speaking generally, the forest is in an excellent condition and of great age in the remoter portions of the 
area occupied by it. In such places the undergrowth is not of that tangled. character so conspicuous in the younger forests of secondary growth. The latter occur in patches along the river bank and in the vicinity of the sites of deserted villages and old farms.

The following species of trees have been exploited for timber in this forest:-

(a.) The Dubini, the ordinary mahogany of the moist forests of the Gold Coast.

(b.) The cedar known as Punkwa (Pseudocedrela cylindrica).

(c.) The cedar known as Tiama-Tiama (another species close to $P$. cylindrica).

(d.) The Biunwè, a lofty species of Detarium.

(e.) The Bossè, a species of Gaurea.

(f.) The N'Yankion (Heritiera utitis).

(q.) The Baya or Y aya (Mitragyne macrophylla).

(h.) The Pebedoum (Lovoa Klaineana).

(i.) The Ehye, or "incense-tree" (Boswellia or Santiriopsis Klaineana).

Of these the species most frequently cut are $(a),(b)$ and $(c)$, partly because their mood is most in demand and partly because they are as a rule more plentiful than the others. This does not, however, exhaust the list of useful timber trees to be found in these forests, as they also contain such species as the Odoum (Chlorophora excelsa); the Baku (Mimusops Djave); the Kokoti (Pynaertia ealaensis); the Kishia (Sarcocephatus esculentus); and the Emrit (species of Terminalia); all of which yield timbers of excellent local reputation.

Other species of economic importance found here are :

(a.) Trees bearing fruit rich in oils.

(1) The Awama (Ricinodendron africanus); fairls plentiful.

(2) The oil bean-tree, Athawah (Pentaclethra macrophylla); common.

(3) The Baku (Mimusops Djave); rather uncommon.

(4) The Kaku (Lophira procera); rare.

(b.) Rubber-yielding plants:

(1) Landolphia owariensis, uncommon.

(2) Tandolphia Droogmansiana? common.

(3) Carpodinus hirsuta; common.

(r.) Trees the wond of which is used for making shingles:

(1) The Offram (Terminalia superba); common.

(d.) Spevies that yicld Gum Copal:

(1) The Asiacha (Cyanothyrsus ogea); uncommon.

Besides the above, other species forming a component part of the forest vegetation are the lofty Chen-chen (Antiaris toxicaria, var. africana); the Duabayi or Dnakobin (Afromosia lariflora), a tree with a conspicuous reddish-coloured bark that peels off in large flakes: the Assom (Omphalocarpum? species); the 
Meinchin (Peltophorum: spacies); the Waw-War (Triplochiton. Johnsonii): the silk-cotton tree (Erindendron anfractuosum); the Dahomah (Piptadenia africana); the dsomah (L'arlia species); the Samanta (Nylia Evansii); the Otisibiri or Flintwood tree (not ret identified): the Essia (Combretum species): this is one of the "Stink-wood" trees; the Nyemidua (Alstonia congensis) ; and a host of other's that for want of flowers and fruit could not be identified.

The above list, howerer, is sufficient to enable those persons acquainted with the forest flora of tropical West I frica to form a mental picture of the type of forest just described.

The oil-palm, though not common, is still pretty well distributed orer the area. As far as I could ascertain only one species of Sterculia appears to be found here, and that is a tree which seems to be a small variety of $S$. curdifolia, a species that is at its optimum in numbers and size further north in the semi-erergreer or mixed deciduous type of forest.

The Mansi River is an important stream and quite deep enough in the rainy season to float down timber of the largest dimensions. Some patches of elephant grass (Saccharum spontaneum?) were seen on its banks.

The dominant species as usual are the Dahomah, Waw-waw, silk-cotton tree, the Emril, Offram, Asomah, and Awama; after which come the Khayas and Pseudocedrelas.

\section{The Forests between Ahirisu (Mansi River') and N'Kwansia (Ankobra River).}

The water-parting between the Ankobra River and its feeder the Mansi is a low one, well covered with tropical evergreen high forest. The valleys leading from it are very moist, and tree-ferns are quite common along the banks of the perennial streams that drain them. On the alluvial narrow plain carved out by the Nansi stream, a good deal of forest has been cleared for farms, the abandoned sites of which are now being occupied by Musanga Smithii and the IVaw-waw. The vegetation clotling the hills contains a fair number of mahoganies and cedars. The Odoum, Kokoti and the gum-copal tree, Asiadua (Cyanothyrsus ogea) are also far from uncommon, whilst the dominant species are represented by the Dahomah, Asomah and WVw-waw. One specimen of the "incense-tree" (Boswellia Klaineana) was seen, as well as some roung examples of the Odoum (Chloro. phora edcelsa) that had been tapped by the natives for the latex, which is used by them for adulterating that of the silk-rubber tree (Funtumia elastica.)

To the north of the water-parting, in the vicinity of $N^{\prime}$ kwansia village, other and more extensive clearings have been made. The older ones are now occupied by the Awama and Emril, as rell as Musanga, Waw-waw, and the Offram, species that form the usual inhabitants of such sites. Another species, with deciduous leaves, Albizia Brownei, has made its appearance in the 
older growth situated to the north of the village where a new species of Afzclia was also found. This species appears to be very rare, and with the exception of those seen near this village I have only come across it on one other occasion, and that was in the forests near the railway station of Imbrahim. 'The presence of the Albizzia mentioned above is an indication of drier conditions, and it is not more than a long day's journey north from here before one comes to a distinctly dry belt of vegetation that stretches right across the country from the Tano River to the railway line. 'This belt is, howerer, not quite dry enough to be occupied by the semi-evergreen or mixed deciduous forests. Nevertheless, it contains a much larger proportion of species with the deciduous habit than the true moist evergreen tropical forests, and can be recognised without difficulty. It is an intermediate type, and bridges the gaj between the two extremes.

'To the east of N'kwansia a good many of the lower valleys have been cleared of regetation for farming purposes, but extensive tracts of forest remain intact. These were examined in detail, and flowering and fruiting specimens of some of the more imporlant species were obtained. Khayas and P'sendocedrelas were frequently met with in this direction, and we were told that they are more plentiful still further to the east. The usual species characteristic of the moist forests are found about here. The Odoum is plentiful on this side, and so is the Baku. The rarer species seen are the Eku (Bombar buonopozense) and Funtumia africana.

The heartwood of a Pebedum (Lovoa Klaineana) that we felled was found to be very similar to that of the East Indian teak (Tectona grandis). Samples were kept for further examination. 'The timber of this species has been exported to Europe from Axim, and, according to Mr. Mensa's local representative, has sold well.

'The trees along the banks of the Ankobra are in places densely covered with the rubber-vine, Landolphia owariensis.

\section{The Forests between the Ankobra River and its Feeder the Sibiri Stream.}

In traversing the country situated between these two streams in an east to west direction, one first reaches an old bed of the Ankobra River, and then the broken ground forming one of the higher valleys of that stream. The whole of this tract of ground is covered with a dense tangled mass of regetation consisting mainly of Apocynaceous climbers, amongst which Landolphia owariensis, Carpodinus hirsuta, species of Clitandra and of Strophanthus are to be seen. Standing up out of all this dense undergrowth arre iregularly distributed groups of such trees as species of C'ynometra; the silli-cotton tree; the Kishia; the Tra-uaw; the Offrum, and the Emril. The ground itself is literally riddled with native diggings (for gold), and the older river gravels are thus exposed in many places. The undergrowth about here is so dense that rrachets have to be used freely to enable one to get about, and the carriers were continually losing their direction. After about an hour's journey through this type of country, one 
comes to a subsidiary range of low hills which are clothed with irregular tropical evergreen forest of good age. Here the undergrowth is much thrumer, and is comparatively free of climbing plants; the over-wood consists of the usual type in which Piptadenias, Partias, Waw-waws, Ec., are the most conspicuous; a few Khayas are also to be seen there. The low country on the other side of these hills has been much cultivated, and contains a few small villages, the older farm sites of which are now overgrown with Wusanga Smithii, numerous Odoums, Emrit, Wauwaw, Bombar buonopozense, some Albizia Broxnci, \&e. The undergrowth is again exceedingly dense, and considerable difficulty was experienced in pushing our way through it.

'To the westward of this valley is situated the main water-parting between the Ankobra River and its tributary the Sibiri. It is a well-defined range and of considerably greater altitude than the hills lying to the east of the small villages mentioned abore. Dense tropical everoreen high forest clothes the greater portion of the range. The trees are of lofty growth, nicely shaped, and the forest contains a fair proportion of useful timber trees. The undergrowth is straight, thin, and comparatively poor in chimbing plants, a characteristic of some of the oldest forests in tropical West Africa. The more valuable species were represented by the Odoum, Khayas (which were bearing fruit), Psendocedrelas (also in fruit), and the Baku. Others of less importance noticed were two species of Piptadenia ( $P$. africana and another gigantic species), Tetrapleura Thomningii; a species of Parkia, enormousspecimens of Antiaris toxicaria, and several species of Ficus that also attain huge dimensions in this forest.

The latter is well worth reserving, both on account of its comparative richness in valuable species of timber trees, and also in order to protect the water-supply of the Ankobra River. There is ample land, covered with younger forests, available for native farms in the valleys both to the east and west of the divide. The Sibiri stream is quite an important feeder of the Ankobra; it is apparently subjected to resy heavy floods in the rainy season, and overflows its banks to a large extent. When the water falls at the end of the wet season the overflow remains in the hollows and gives rise to a succession of swamps that are occupied by a dense growth of the Tombo Palm (Raphia vinifera) and scandent palms belonging to the genera Calamus and Ancistrophyllum. 'The forest along this stream has been leased to an American firm represented by a Mr. Parne, I think, who was, howerer, absent on leave at the time of our visit. Large numbers of malogany logs were seen lying in the bed of the stream awaiting the next floods to take them down to the Ankobra and thence to Axim.

The forests a long the lower course of the Sibiri have been cleared for farms, and the secondary growth that has sprung up on the older clearing's is formed by species such as the Emrit, Odoum, Waw-waw, Offram, Albizia Brounei, de., that are generally the first amongst trees to occupy such lands. As the locality looked a promising one, a day was deroted to a thorough exploration of the forest vegetation on the north bank opposite Mr. Payne's camp. 
'This portion has been well exploited, and the numerous dragging paths cuabled us to get in all directions good clear views of the forest, only attainable otherwise by keeping to the roads or the beds of streams.

Several species of trees new to us were found here; unfortunately they could not, for want of flowering or fruiting specimens, be identified. They include:-

The Jumtwa, a medium-sized deciduous-leafed tree (it was quite bare of foliage at the time of our risit), that possesses a very corky bark covered with small, circular depressions; the wood is said to be grood and to have sometimes been exported to Europe.

The Dubima (IVaw-Saw name) or S'iriko (Apollonian name), also a small tree, with a bright vellow wood, which is used by the ratives for manufacturing door and window frames. A yellow dye is extracted from the bark, which is further used both as a medicine for ulcers and for making " bitters." In addition to this, a boiled decoction of the bark is used as a medicine for stomach-aches. This is apparently quite a useful tree to the natives.

The Kucte prepre (Waw-Saw name). A tall tree with the bark of a Cyanothyrsus and the foliage of a Khaya. It does not appear to be put to any use by the natives. A new species of silk-cotton tree, the Vyi-na-kobin (Bombax brevicuspe), was discovered here. It grows to a large size and sheds its leaves in the dry season; the natives use a decoction of the bark for dyeing their cloths a rich reddish-brown colour. The dye is said to be a fast one. The bark is first beaten and then soaked in water and the cloth allowed to remain in this infusion for three or four days, which allows sufficient time for the fibres to be thoroughly stained. The stems of this species are often hollowed out into canoes, which are said to last for three years. The Burmese make a similar use of the stems of the Dido tree (Bombax malabaricum).

A new species of Parinarium that grows into a fine large tree with a spreading crown was discovered in this locality. The particular specimen felled was much festooned with a rubbervine, Landolphic Klainei, which is fairly abundant about here. Other species of rubber-yielding vines, such as Landolphia owariensis, and a species that appears to be the typical L. Droogmansiana of De Willdeman, are also to be met with in this forest.

Khayas (the ordinary Dubini of the moist forests of the Gold Coast) and two species of Pseudocedrela, the Punkua and TiamaTiama, are fairly numerous, though large numbers, especially of the former, have been felled for the timber trade.

The age gradations of these more important species are better represented here than is usually the case with the over-mature woods of this country. On the whole I think that an early opportunity should be taken to reserve as much as possible of the valuable forests clothing the drainage area of the Sibiri stream.

A particularly fine bamboo, apparently a species of Dendrocalamus, that forms extensive clumps, is rather common about 
this locality. It is, however, I believe, an introrluced species, as I have never found it far away from existing villages or their old abandoned sites. It will be interesting to learn from what part of the world, and how, it was introduced. It lias a rather close resemblance to $D$. Hamiltonii, from Burma, but does not attain quite such large dimensions.

\section{The Forests on the South-Eastern Slopes of the Antobra-Tano Water-Parting.}

From Mr. Payne's timber camp we followed up the Síbiri stream a slort distance, then left it, and after passing orer some rough country covered with low hills for a mile or so, commenced the climb of the main water-parting, the crest of which we soon reached and followed as far as the village of Anyinabirem, where the main road from Akropong to Akikere comes on to the ridge from the east. We then left the latter, and turning to the southwest followed an important spur that eventually brought us, after many ascents and descents and a long and fatiguing march, to the village of Alikere, which is situated in the Tano drainage. The forest along that part of the Sibiri stream followed by us has been much cut about for farming purposes. The growth improved, however, after we left the river, and the main waterparting, which is, I should think, something like 800 to 1,000 feet above sea level, is covered with really fine, lofty evergreen forest. Several large clumps of bamboos were seen before the foot of the ridge was reached, and flowering specimens of a second species of Guarea, a genus to which some excellent timber trees belong, were procured. This species is also called Bosse by the natives, who do not appear to distinguish between the two kinds.

As regards the vegetation on the main water-shed, it is composed of excellent growth, amongst which magnificent examples of Khaya, the Tiama-Tiama (Pseudocedrela species), the Irotio or Odoum (Chlorophora excelsa), the Punkwa (Pseudocedrela species), gigantic specimens of Antiaris toxicaria var. africam, Cyanothyrsus ogea (the gum copal tree), the Pebedum, the Bosse. Huge Piptadenias and silk-cotton trees are to be found growing in great profusion. A few examples of the $K$ okoti and the rubber tree Funtumia elastica were also seen. Of course, the cosmopolitan and dominant species such as the Dahomah, Offram, Waw-waw, and a large species of Parkia were much in evidence. There is a marked tendency for Albrizia Brownei to occur in greater numbers in the secondary growth near villages as we proceed further to the westrard.

After leaving Anyinabirem village the path follows a long descent to the south-west, and then ascends an important ridge that is almost as high as the main divide. Here the fine type of forest just described reappears and continues till just before the village of Bantama is reached, where it is replaced by the secondary growth usually found near native labitations. Oil palms were numerous along this portion of the day's march. A very fine flowering specimen of Erythrina tomentosa was seen close to the village. It was practically bare of leares, but 
literally corered with a beautiful bloom of pink blossoms, and formed a conspicuous object.

Between Bantama and Kiwamang the forest is on the average much younger and of secondary growth. T'he Waw-waw is becoming more dominant than ever about here and completely outnumbers any other species. The usual trees of this type of forest were met with, including a few Khayas and I'seudocedrelas and an inteasing proportion of the larger species of P'iptadenia. Bixtensive patclies of a large bamboo (Dendroculamus ? sp.) were seen near the streams forming the water supply of the villages.

The forests clothing the main water-parting and the subsidiary ridge are well worth taking up as reserves. The secondary growth should be left for the farms.

\section{The Forests in the Drainage Area of the Lower Tano River.}

Between the villages of Akikere and Tomento, which latter is situated close to the banks of the 'Tano River, the country, in a north-westerly direction from the former, is hilly and much broken, but is not dominated by any important ranges. At about two-thirds of the total distance between Akikere and the Tano is situated the large and important town of Asankagwa, quite the largest we have seen west of the railway-line. The adjacent country is also occupied by numerous small villages, so that the total population inhabiting a comparatively small area is fairly large and has in accordance with the wasteful system of cultivation adopted by the natives necessitated extensive clearings in the forests from time to time. These clearings or their now overgrown sites are often found at a long distance from the inliabited centres, and account for the very irregular, patchy condition of the forests passed through.

Generally speaking the forests are comparatively young and of secondary growth that has sprung up from time to time on the abandoned areas. Here and there, however, where for some reason or another the land has not been taken up for farms, belts and patches of much older high forest are to be met with; in such localities trees of economic importance are fairly plentiful, and include the ordinary Dubini (mahogany), the two species of Pseudocedrela usually found in the tropical evergreen forests of this zoue, the Odoum (Chlorophore excelsa), the Baku (Mimusops Djave), the Bossè, the Pebèdum, the Asiadua or gum copal tree (Cyanothyrsus ogea), and a species of Trichitia that is not uncommon in the corresponding forests of Southern Nigeria.

1)uring the last few days indications had not been wanting of a gradual change in the climatic conditions prevailing in this part of the country. From Akikere onwards the forest vegetation, though still of the tropical evergreen type, showed unmistakeable signs of being invaded to a much greater extent by species that are at their optimum in regions characterized either by a markedly smaller annual rainfall or, in the event of the rainfall being still sufficiently high to satisfy under ordinary circumstances the wants of the typical tropical erergreen regetation. by a climate of which the dry season is longer and more pronounced. 
Species such as the Kaku (Lophira procera) and the N'yankon (1/critiera utilis) have practically disappeared from these forests, whilst others, such as the Waw-waw (one of the species that has a great distributional range on the Gold Coast), the Offram, Sterculia cordifolia, Albizzia Brownei, and the silkrubber tree (Funtumic elastica) are to be found in much greater abundance than hitherto. The increase in the proportion of Wark-waws to other species has been further intensified by the local custom of protecting" it as a "standard" in the clearings made close to villages. I could get no satisfactory explanation as to why that species and occasionally the Emril and Offram as well are thus faroured by the inhabitants.

However, these three species are actually far more abundant in the semi-evergreen or mixed deciduous forests (associated with a drier climate), eren where the former are of a great age; and as such their comparative abundance or scarcity is a safe indication by which to gauge the climatic conditions, notwithstanding the fact that their growth may have been favoured in particular localities by the action of man, as is the case here.

I do not think that the change in climate experienced in the lower drainage area of the Tano River is mainly due to the destruction of the forests; it more probably depends to a great extent either on the absence of a well-marked monsoon current or to the absence of those cyclonic movements that usually bring rain during the dry months of the year in other parts of West Africa or to both causes. Nevertheless as this is a hilly part of the country the destruction of the forests is bound to further intensify the effects of a defective or irregular rainfall. As was to be expected from the general character of the regetation, the water supply of this portion of Upper Wawsaw is far from being as abundant as it is in localities further to the south and southeast. It is not, however, a precarious one, and in the neighbourhood of the larger streams swampy areas are abundant. The tracts of countiy still covered with high tropical evergreen forest, though of the modified type just mentioned, are also well watered, and it is only in the areas that have been much subjected to farming that it is scanty.

This modified type (an intermediate condition between the moist tropical evergreen forests and the mixed deciduous or semievergreen forests) extends in a broad belt, as will be described later on, right across upper Denkera to the railway-line between the stations of Dunkwa and Imbrahim.

The Tano River itself is a fine large stream about here, and has rery few sandbanks visible even at this, the driest, time of the year. It is not deep opposite Tomento and can be forded at most places. A few small patches of "Savannah forest," characterized by the presence of tall species of grasses, are also to be met witl along the banks of the stream; they are distant and feeble outliers of the great Savannah forests of Northern Ashanti, between which, however, and this locality, a very broad and extensive belt of moist evergreen forest interrenes.

Close to the banks of the river, where we encamped in a moist patch of forest, we saw some Bayas and the Kaku, which is here 
restricted to the moistest localities close to the streams. Xylia Evansii on the other hand is getting nore numerous and conspicuous as a member of the forest regetation. Musanga Smithii appears to be past its optimum; though still numerous, the growth is becoming lanky and the foliage less dense.

I learnt from one of Mr. Nicholas's native employees that the forner has obtained a timber and mining lease of the country adjacent to the Tano River from the local chiefs. Some not very formidable rapids are said to exist on that stream near the village of Brimang, and it is proposed to outflank them by using a traction engine to haul the logs out before they reach the obstructions and to drag them to a point on the river below the latter, whence they cau be again thrown into the water. I fincy the great difficulty to be overcome in this scheme is to get the traction engine as far up the country as Brimang.

Hearing that there was an exteusive bit of uninhabited country situated to the north-west of our camp, on the other side of the river, Mr. Burbridge and myself decided to go and explore it. As no villages were said to exist within two or three days' journey of the centre of the blank space shown on the map we had to leave the bulk of our carriers behind at Tomento and to proceed with a few men and a light equipment and to arrange for food to be sent out to us at regular intervals.

On crossing the river the right bank was found to be fringed with a narrow belt of very moist evergreen forest, the existence of which is due to the abundant supply of moisture available in the soil close to the stream; shortly after leaving this the path, made by rubber collectors and hunters, that we were following, began to ascend the slopes of a fairly high hill, on a flattened shoulder of which we came across the long deserted site of an old village. The forest on this slope of the hill consists of irregular secondary growth that has sprung up on the old clearings, and contains the usual species characteristic of such localities. Owing, howerer, to the drier conditions prevailing here such species as the Waw-waw, Offram, Emril and Odoum (another species with an extensive distributional range) are found in greater abundance than in the moister localities to the soutl-east and south. Near the summit of the lill the growth is much older, but still irregular and of secondary origin; it contains both the large and small species of Piptadenia, a few Khayas, Pseudocedrelas, Pentaclethra macrophylla, and large numbers of the Thav-waw; a few Offrams were also seen.

The second tier of vegetation contained a fair number of Funtumia clastica, some of which have been tapped to death, and the robust climber Carpodinus hirsuta which lias also been extensively tapped; in some cases on the "herring-bone" system. The Jatex of the latter is largely employed for adulterating that of the former. The resulting coagulum is a rubber that is of much inferior quality to that obtained from the pure Funtumia latex aud of slightly better quality than that obtained from the vine. In places almost every species of plant that yields latex of any sort whaterer, quite irrespective of the fact as to whether the latices contain a large percentage of caoutchouc or not, such as the Odoum, the Nyamedua (Alstonia congensis), 
various species of Ficus, Funtumia africana, several kinds of Landolphia, Carpodinus, Clitandra, \&c., is tapped and the latices then mixed together and coagulated. The result is a rubber of very poor quality.

Aftel surmounting the hill mentioned above we got on to a main lange, the crest of which we followed for several hours, with many ascents and descents, before we reached water and formed our camp for the night. This range is clothed with the same type of forest, but the latter is open in places and contains an increased proportion of Sterculia cordifolia and Sterculia Barteri, the latter of which made its appearance in any large numbers for the first time. The soil is dry and rather rocky, and is covered in places with a dense tangled growth of a species of moody leguminous climber that I have only seen on this ridge. Some stems of the "Flint wood" tree that had been cut by the rubber collectors and were lying about in a moist patch of forest were found by me to be quite rotten. I could easily push my walking-stick through them, so I very much doubt whether the wood of this species is as durable as it is made out to be by the European miners. It appears to coppice freely, judging from the healthy-looking shoots that have sprung up from the stumps left in the ground.

The night at the first camp was quite cold, and during the whole of our stay in the hilly country to the west of the Tano River the climate was found to be distinctly bracing.

The second camp was situated in a deep valley some few hours' journey to the north-west of the last one, on a tributary of the Tano River. Here water is abundant and of very good quality, coming as it does from a hill torrent. The valley itself is narrow and closely shut in with hills, but as it is very well watered the forest vegetation is that characteristic of a moist locality. On ascending the hills, however, it becomes of a much drier type, though still belonging to the tropical evergreen formation, in which such trees as Sterculia cordifolia and $S$. Barteri are far from uncommon. Some fine examples of the Tiama-Tiama (species of Pseudocedrela) and the ordinary Dubini were also seen in the hill forests, which in places are composed of trees of lofty growth, amongst which some exceptionally fine specimens of Antiaris toxicaria var. africana, Cyanothyrsus ogea, and the large species of Piptadenia may be specially mentioned.

These hill forests are much more open than the moister ones in the valley lower down, and it is possible to walk about under them without the continual use of the "machet." The soil is also less moist and covered with a fairly deep laver of $d r y$ leaves that render silent walking almost impossible; in this respect the forests are similar to the semi-evergreen or mixed deciduous type belonging to the middle zone of vegetation, the zone that intervenes between the open savannahs and tree savannah formations of the hinterland and the moist tropical evergreen forests of the maritime zone, where the monsoon currents are strongly marked. On rocky portions of the ridges dense tangled masses of lianes, consisting of rubber vines belonging to the genera Carpodinus, Clitandra, and Landolphia and of Combretaceous 
plants occur, and in localities exposed to strong winds as on some of the higher summits both the lianes and their tree supports are to be seen leaning over to one side in the direction of the prevalent air currents. Here the tree growth is also more or less stunted. These differences in growth are found within quite a small range of altitude, the highest summits of the hills being only a few hundred feet above the level of the valley, which, however, from its shut-in position, is fairly well protected against dry winds - a fact that explains the markedly humid character of the air below, which together with the moisture in the soil by the sides of the streams induces the luxuriant tropical vegetation to be found there.

Another day was spent in furthur exploration of the surrounding forests, and then a return was made to our main camp on the Tano River. I was rather disappointed in these forests as we were led to understand by the guides that they were extensive and practically virgin in character. This we found to be very far from the case, and the whole tract of country showed unmistakable signs of having been once pretty well inhabited. Large tracts of forest were found to be of secondary origin, and signs of villages having once existed here were also not wanting. In fact, on our return to the village ('Tomento) the chief admitted that a very long time ago the country had been inliabited by people who had since moved mestwards.

The proportion of valuable timber trees to the other species is also comparatively small in the forests examined, which are otherwise, on account of the absence of villages, \&c., well suited for reservation.

On the 11th February, 1908, we left Tomento to return to the railway. Proceeding by the road Tomento-Agona-MansoTotonso-Supon-Princesu-Dunkwa we arrived at the last place, which is situated on the railway, on the 17 th of that month.

The wooded country traversed during this journey is situated within the drainage systems of the Tano, Ankobra, and Prah Rivers. The portion in the Tano basin lies to the north-east of Tomento, and extends in that direction almost as far as the village of Manso, which is just outside it, and belongs to the Ankobra drainage. These forests of the Tano basin are chiefly of secondary growth and comparatively young, the older ones, approaching the virgin condition, being confined to the summits of some of the higher hills which are situated between Brimang and Manso. As a rule the valleys are swampy and occupied by a dense growth of Raphias and scandent palms belonging to the genera Calamus and Ancistrophyllum. Outside these swampy areas, however, the regetation though still of the evergreen tropical type is intermixed with a fairly large proportion of decidunus leafed species which give it a somewhat drier look than the typical moist evergreen forest to be met with nearer the coast. This drier form of evergreen forest has ahready been described when dealing with the forests seen near the Tano River and is the predominant kind of forest vegetation met with from Manso due eastwards to the railway. In swampy areas and along the banks of the larger streams it of course reverts to a 
woister type and some extensive patches of such forest rere passed through in which the ordinary Dubini and the two species of Pseudocedrela (the Punkwa and the Tiama-Tiama of the natives) are quite plentiful. Other species noticed between Brimang and Manso were the cosmopolitan Dahomah, Waw-vaw, Offram, Emrit, Odoum, as well as examples of the Baku, Kokoti, and Funtumia elastica; the last, however, is confined to the drier parts of the forests of which it now begins to form a conspicuous and important member. Beyond Igona the species of Parkia, so plentiful in the moist forests further south, were found to be getting scarce, and the same remark applies to the Kaku and the $N^{*}$ yankon, which are practically absent from this area.

From Manso eastwards, almost as far as Princessu, we marched through the drainage area of the Ankobra River, which is clothed about here with forests exactly similar in character to those just described.

On rich alluvial soil close to the banks of that river the ordinary Gold Coast mahogany is very common indeed. Here the age classes are well represented, and the forests are in a satisfactory condition. Such areas are liable to be under water during the flood season, and it is interesting to find that the Gold Coast mahogany has the same partiality for localities subjected to such inundations as its near congener Khaya Punchii, the common mahogany of Southern Nigeria.

These rich patches of mahogany forest are abundant in the neighbourhood of Totonso on the Ankobra River.

What appears to be a fourth species of cedar (Pseudocedrela) with very small capsules was met with in the forests between the villages of Adwenyede and Supon.

The most important characteristic of these forests on the middle drainage area of the Ankobra is the abundance of the silk-rubber tree, Funtumia elastica. It is inclined to be gregarious about here, and the more densely-stocked areas generally occur in regularly-defined belts. The richest forest of this species that we came across is situated close to the village of Jauboa, between it and Domiabra. A rough valuation survey along a line 300 yards long and 44 yards wide, gave an average of 16 plants (one foot in girth and over) to the acre; a most extraordinary high figure. Except for the irregular spacing, the forest looked much like a thinly-stocked plantation.

As usual, the tapping of these trees by the natives has been much overdone, and large numbers of plants were found to have been killed by the treatment they have received. Other latexvielding species, such as the Odoum (Troko of Southern Nigeria), Alstonia congensis, and a small unidentified tree called Okure by the Fantis, that are found growing in the vicinity, have also been tapped for the purpose of mixing their latices with that of the Funtumia elastica.

Yet another species of cedar (Pseudocedrela) was fonnd close to the village of Assawasè. It has small capsules which open 
at the base, just the reverse direction in which the capsules of the other members of the genus open out.

East of Totonso the forests are, comparatively speaking, so dry that the Asomah (Parkia species) has practically disappeared from the scene.

Otherwise the forests are quite rich in mahoganies, cedars, Baku, Lokoti, Bossè, \&r., any among less valuable species are the War-war. Offram, Dahomah, and the large species of Piptadenia.

The large bamboo (Dendrocalamus species), first met with near the Sibiri stream, is very abundant close to the villages of this part of the country, and the ground under the clumps affords excellent camping sites.

The forests along the middle reaches of the Ankobra do not appear to have been leased to anyone, and as they are very rich in valuable economic plants, more especially so in rubber-yielding trees, an early opportunity should be taken to select and reserve the best areas.

From about the neighbourhood of Supon one gets into the drainage area of the Offin River, a feeder of the Prall. The part of the country walked over between here and the Atasi Mines (Princessu) is very hilly, and is covered for the most part with secondary forest of a rather dry type, in which the majority of species noted as characteristic of the tropical evergreen forests are to be met with. Mahoganies and cedars are not uncommon, but, owing to the very lillly nature of the country and the fact that the ranges are running parallel to the direction in which the nearest large rivers flow, I faney it will prove too costly an operation to get the timber out with the appliances in use out here at the present time.

About an hour-and-a-half's journey from the mines, one comes on to very extensive clearings that have been marle for planting the food crops, on which the large population engaged on the mines are dependent. I fancy some of the prodnce is also taken down to the railway and sold in Dunkwa.

The forests close to the mines have been cleared for firewood, the only species left are the Dahomah, the oil bean tree, Pentaclethra macrophylla, and a species of Brachystegia, the wood of all of which is too difficult to split into billets. Owing to the rather dry character of the forests about here, I am inclined to think. if the water supply of the country is to be preserved, that some restriction should be placed on the wholesale fellings that take place annually.

The regetation clothing the more important hills where the sonrces of the streams are situated should he protected against such damage.

During our stay at Princessu, we visited the water supply of the mines; a dam has been constructed across the perennial stream just below the point where it debouches out from the hills on to a fairly level but narrow portion of its valley. Quite a large quantity of water has thus been stored and pushed back 
up the valley of that stream and of one of its feeders. It was interesting to notice the effect of this flooding on the forest vegetation of the submerged area. 'Two species, Funtumia africana and Funtumia elastica, have withstood most effectually the prolonged submersion of their roots and the lower portions of their stems. Most of the other species have succumbed to the new conditions; of the two Funtumias, $F$. africana has proved to be the more resistant.

As the forest regetation of the lower and middle portions of the Offin River drainage has been described in another chapter, I will not refer to it here except to remark that it is almost as equally rich in rubber trees (Funtumia elastica) as that passed through on the journey from the Tano River to the railway line at Dunkwa.

\section{The Tarkwa and Abosso Mines: Supply of Fuel.}

On our return to Tarkwa from the Tano River trip, I was obliged to proceed to Sekondi to arrange for carriers to replace those out of the first lot that had fallen sick. Returning to the former place, I spent some days in examining the fellings that had been made round the mines for supplying them with fuel. Mr. G. A. Stockfeld, the General Manager, very kindly placed at my disposal all the information he possessed on the subject, and, in addition, accompanied me during an excursion made in the forests near the Abosso Mines where similar fellings are taking place.

As a general rule, the denuded areas have been sufficiently well re-occupied with vegetation to prevent any erosion of the hillsides during the rainy season. The umbrella tree Musanga Smithii) has effectually occupied most of the clearings, and is affording ample protection to the soil.

The clearings made near Abosso are much more extensive, as several mines belonging to different companies exist in that neighbourhood; a good many of them, howerer, have now been abandoned, and the cleared areas will no doubt be gradually re-afforested in the course of time. There are a few places on some of the steeper hillsides that show signs of erosion, but I think they will soon be re-occupied by weeds and other regetation, and be protected against further damage.

The fuel mostly used on the Tarkwa Mines is procured from the following trees:-

(1) The Kaku.

(2) The Engantan (probably Heritiera utilis)

(3) The Aphona (not identified), which is said to yield a goor wood fit for export.

(4) The Grabossi, which yields a very hard wood.

(5) The Dubinrilli, a local name for the Dubini or ordinary mahogany.

(6) The Kokoti (Pynaertia ealaensis).

(7) The Athawah (Pentaclethra macrophylla). 
(8) The Dianfutu (could not be identified), said to yield an excellent fuel.

(9) Kussiabah (same as Kishia). Good fuel.

(10) Adjava, ditto.

Every species except the Dahomah (Piptadenia africana), however, is cut down for firewood. Those mentioned above give the best results.

During the five years and nine months, August, 1902, to the end of January, 1908, the fuel consumed on the Tarkwa Mines amounted to 37,000 cords, and this was obtained from clear fellings made on 3,000 to 4,000 acres. The rearly consumption thus amounts to 6,400 cords, to supply which about 600 acres of forest has to be felled. The corresponding figures for the Abosso Mines are:-Period, five years (1st January, 1903, to 31st December, 1907); consumption, 39,696 cords of fuel; area, 3,000 to 4,000 acres. The mean annual consumption in this case is 7,939 cords, for which an area of about 700 to 800 acres has every year to be cleared of forest growth.

Mr. Stockfeld is re-afforesting portions of this ground with the following species of Eucalyptus and Melaleuca:-

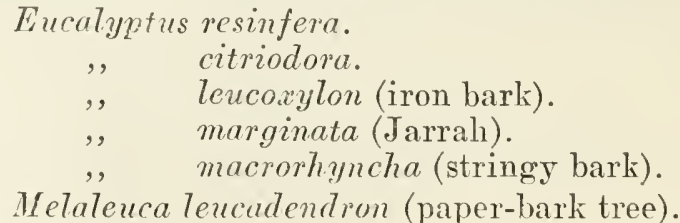

The trees already planted seem to be doing fairly well; it is to be hoped that the experiment will prove a success.

After completing the inspection of the areas that are being exploited for frewood, Mr. Burbridge and myself proceeded to Imbrahim, a station on the Sekondi-Kumasi Railway, where we spent a few days in examining the forests to the east of the railway line. I found them to be rather disappointing, especially the one known as the Fetish or Sacred Forest. Generally, the forest consists of secondary growth, but patches of much older high forest are not wanting, and the locality is fairly rich in mahoganies and cedars. The portions close to the railway have been heavily exploited, and logs were found lying all about the place. Several species of the commoner forest trees happened to be either flowering or fruiting at the time of our visit, and we were thus able to add considerably to our collections.

This is about the extreme northern limit of the N'Yankon (Heriticra utitis) which, owing to the rather dry character of the country, is confined here to the vicinity of swampy ground. The ITax-waw and Offram, usually the dominant species, are comparatively scarce in this locality, but some rather rare trees, such as a new and undescribed species of Afzelia and a Bombar (Bombax brevicuspe), were seen.

Rubber-vines appear to be plentiful in the forests, and a few Funtumia elastica are also found there. The Imbrahim forests, with the exception of the sacred one, which is rather moister in 
character, belong to the dry type passed through on our way back from the Tano River.

The Pseudocedrelas about here were practically bare at the time of our visit, and were just breaking out into new leaf. Most of the Dubinis seen were covered with fruit, and the railway line was strewn with their seeds. I noticed that several cedars, mahoganies and the new species of Afzelia have been left as standards on the areas cleared for farms. The inhabitants have probably realised that these species are valuable products of the land.

The next forest examined is the one known as the Tsifufu Forest; it is situated further north and on the west side of the railway.

\section{The Forests of Soutimern Ashanti.}

From the 9th March to the end of that month the time was occupied in examining the forests of Southern Ashanti. During this period, the forests to the west of the railway and to the north of Dunkwa were visited, as well as those between Oboase and the Adra River, the Adra and the Offin Rivers, to the north and south of Nkwanta, those along the Bibiani-Kumasi Road, and along the Bibiani-Mim Road.

The most distinctive characteristic of these forests, as compared with those south of the railway station of Imbrahim, is the much larger proportion of deciduous leaved trees to be met with in them; this comparatively dry belt of mixed deciduous and evergreen forest stretches across the country to the west and south-west as far, at least, as the Tano-Bia water-parting in Upper Denkira; it is par excellence the home of the cedars (various species of Pseudocedr $l a$ ) and the indigenous rubber tree, Funtumia elastica; it is also very rich in mahogany (at least two species of Khaya) and, taken all round, comprises, from an economic point of view, the most valuable forests which the country possesses.

As far as the forests of cedar and Funtumia elastica alone are concerned, I very much doubt whether tropical Africa can show their equal in any other portion of the continent. Moreover, they are rich in other valuable species of timber-trees, such as the Khayas, the Odoum (Chlorophora excelsa) which is particularly abundant, and the Batu (Mimusops Djave). Indeed, the only important timber-trees absent from this type are the $K a k u$ (Lophira procera) and the Tankom (Heritiera utilis), the distributional ranges of which practically cease at the latitude of Imbrahim on the railway. Roughly speaking, this is the northern limit for these two species, which are never found very far away from the maritime zone of vegetation.

The potential forest wealth of Southern and Western Ashanti is enormous, and its value must increase rapidly from year to year as the supply of American mahogany and cedars diminishes. The exhaustion of the American sources of supply is, from overexploitation, likely to be realised in the very near future, and 
of late the annual imports to Europe and America of African moods have already exceeded the total output of that from Central America and Cuba. The forests of Ashanti are so valuable that a special effort should be made to protect the richest of them and bring them under organised control; they are well worth any expenditure likely to be incurred for this purpose.

In some respects it is unfortunate that the only available line of export for these forests is the Sekondi-Kumasi Railway. Though several large streams, capable of floating logs, drain the area in question, ret, owing to the presence of rapids and other obstructions, they cannot at present be utilised for that purpose, and for some time to come, at all events, exploitation will have to be confined to the ricinity of the railway.

This, however, is not an unmixed evil; their very inaccessibility will indirectly afford a certain amount of protection to the forests till such a time as the country is in a position, by opening up new lines of communications, \&c., to tap these new sources of wealth.

As far as I can find out, there appear to be only two really serious obstructions on the Tano River. This stream drains a very extensive and rich tract of forest country, and the removal of the two obstructions at an early date is urgently called for. Mr. G. H. Dawe, Agent at Sekondi for Messrs. Swanzy \& Co., who has had a long and unrivalled experience of timber exploitation both in Central America and the West Coast of Africa, informs me that the lower obstruction on the Tano River, just above Tanoso, can be removed at no great expense by the judicious blasting and removal of certain rocks, and by the construction of a boom to direct the timber into the proper channel.

That gentleman has studied the question on the spot for some gears, and it would be adrisable to consult him on the points involved before active measures are taken to clear the channel. As a rule, such operations can only be successfully undertaken after personal knowledge of the behaviour of the river at all seasons of the year has been acquired by the operator. As regards the second obstruction, which is situated at a point much higher up the river, somewhere below Tomento, very little is known, but it is supposed to be less formidable than the lower one.

In any case, the attempt to clear the channel at both these places should be made, because, if successful, it will mean the opening up of sereral thousand square miles of some of the richest forests in Africa.

The other rivers draining this extensive tract of mixed deciduous forest are the Ankobra and the Offin, with its feeder the Adra. 'The former is said to be free of all serious obstructions, and the latter are also reported to be clear. Unfortunately, the Offin is a feeder of the Pra River, and the latter has sereral obstructions (rapids) along its course. These should be examined and studicd by an expert with a view to clearing a channel suitable for the conveyance of timber. In this connection I may add that the expenses connected with such operations are, as a 
rule, nothing like as great as those incurred in making similar obstructions navigable to boats.

If the worst comes to the worst, there is always the alternative, in the case of the forests drained by the Offin and its feeder the Adra, to collect the timber floated down the two streams at the point where the railway bridge crosses the former, and then to send it down the railway to Sekondi. This, however, will iuvolve additional handling of the $\operatorname{logs}$, and all such handling means extra expense. For this reason it may, in the case of Uffin timber, be advisable for the railway authorities to reduce their freights.

As regards the protectiou of the forests themselves, the main dangers to guard against are, first, the depletion of the forests from over-exploitation; and, secondly, their destruction by the natives for farming purposes. The former can be met by fixing a minimum girth for the more important species that are being exploited for trade purposes, and the latter by selecting and taking up as Forest Reserves the richest areas and protecting them strictly against all fellings except such are made under the technical supervision and management of a properly constituted Forest Department. Un no account, except under the strictest professional supervision, should farming be allowed on such areas, nor should farming, as a right, be admitted in the Reserves.

The damage done to the forests by farming is far greater than that due to orer-exploitation, because the latter is limited to certain species only, whilst the former makes a clean sweep of everything, and these clearings are then very often re-occupied by species (that happen to thus get a favourable start in the struggle for existence) other than those that formerly occupied the area. The character of the "secondary" forest that springs up is thus very often different from that which previously occupied the land; moreover, the proportionate numbers of the various species are frequently altered as the result of such clearings and the alterations are in general more favourable to those species that do not at present happen to be of any economic value to man.

When all is said and done, reservation is by far the most satisfactory method of ensuring the protection of any particular forest, because under proper organisation the protection is complete and supervision concentrated. This is not possible when merely a few of the more valuable species are protected (by fixing a minimum felling girth or by selection for felling) generally all over the country.

Nor must it be concluded that wholesale reservation is necessary in order to ensure the permanent existence of forests sufficiently extensive to meet the ordinary demands for forest produce.

Experience has shown that from 35 per cent. to 40 per cent. of the total wooded area only need be taken up as reserves, even when such reserves include the forests that may require protection, in order to preserve the climatic factors of the locality. There is thus ample unreserved land left at the disposal of the natives for farming purposes. 
If in addition to this, owing to the land laws recognised in this part of A frica, the principle is recognised and acted upon that the native communities are entitled to a share of the produce of the land and that accordingly they should share with the Government any revenues that may be derived from exploiting the reserves, then they can have no reasonable grounds for objecting to reservation within the limits mentioned above.

Objection on their part to a system that-

(a.) Ensures a permanent supply of forest produce;

(b.) Ensures the reservation and improvement of the climatic factors of the locality;

(c.) Gives them a share in any pecuniary benefits derived from such reservation; and

(d.) Provides ample land on which to farm:

can but emanate from those who are averse to improvement and the establishment of law and order in the management of their affairs.

At the same time it should be recognised, and provided for, that the technical department under which the management of the reserves is placed must be absolutely unfettered in carrying out such professional operations as are necessary to ensure the objects of reservation. The inhabitants should not be allowed such rights and servitudes in the reserves as are likely to threaten the existence of the forests or interfere with their proper management.

Under the existing land tenures the paramount Government cannot reasonably hope to benefit to any large extent by the revenues derived from the reserves, as it does in India and Burma. It should suffice if the revenues pay for the expense of the department, and at the same time leave a small percentage of profit over to be shared with the native communities owning the land on which the reserves are situated.

When legislating for the legal creation of the reserves this point should be kept in mind, and it ought to be definitely stated that only the nett profits (after all the expenses of management bave been deducted) are to be shared in the manner indicated above.

Except in cases where reservation is imperatively required for preserving the water supply or aresting the progress of desiccation, Sc., areas taken up for reserves should, as far as possible, be selected in localities free from villages or large farms. If the inclusion of villages is unaroidable. then the latter should be bought out with all their rights and provided with suitable land elsewhere.

Generally speaking the ordinary rights exercised orer the collaction of forest produce for the local requirements of the people residing over the vicinitr of the reserve should, as far as possible. be respected, unless the exercise of such rights threatens the existence of the forest or is likely unduly to interfere with its management. 
Reverting now to the forests themselves, the first one cxamined in Ashanti is that known as the Tsifufu Forest, situated to the west of the railway, between the 104th and 107th miles. 'This forest is drained on its eastern side by the Jym River and on the west by the Ofina stream, and its feeder the Subinsu; the ground is hilly and culminates on the north in Nemp's Peak, a high prominent hill from which an extensive view of the surrounding country can be obtained. The forest is being exploited by Messrs. Nicholas and Brett, but at present operations are confined to the eastern portions adjacent to the railway.

On this aspect (eastern) of the hills the forests are of secondary growth, the larger Khayas (mahoganies) and Pseudocedrelas (cedars) having been left as "standards" when the ground was first cleared for farms. The secondary growth, however, is fairly old and the leaf canopy is now nearly complete. Deciduousleafed trees such as Sterculia Barteri, Sterculia cordifolia, Ricinodendron africanus, the Tiama-Tiama (Pseudocedrela sp.), the Offram (Terminalia sp.), Tetrapleura Thonningii, \&c., are now a prominent feature of the vegetation and give it the "mixed" appearance so characteristic of the Ashanti forests. On the western slopes, drained by the Ofina and its feeder the Subinsu, the proportion of erergreen trees to the deciduous-leafed ones is slightly greater than prevails on the eastern aspects drained by the Jym River. The trees are of more lofty growth and both the large and small-capsuled cedars (Tiama-Tiama and Penkwa, both species of Pseudocedrela), as well as the ordinary Gold Coast mahogany (Khaya sp., the Dubini of the Fantis), and the Odoum of the Ashantis, are common about here. The summits of the higher hills are clothed with high forest containing the gum copal tree, Cyanothyrsus ogea, Piptadenia africana, and a large unnamed species of tree of the same genus that is very common on these hills. One fine example of the rare Pebedum (Lovoa Klaineana), a tree that yields an excellent timber and is closely related to the cedars, was found, and good specimens of fruit procured from it. The Ashanti name for this tree is Kuatanuro.

The next forests to be examined were those in the vicinity of Oboase and between it and the Adra River close to the village of Hun. The first four miles of the path passed through land leased to the Ashanti Goldfields Corporation. Timber has been cut here (within a radius of two miles from Oboase) for the use of the mines, both for fuel and construction purposes. "The consumption of fuel for all the mines belonging to that Company amounts to an average of 3,000 cords a month. During the last ten years some six square miles of forest have been depleted of timber for this purpose. Whe trees spared when the fellings are made are the Dahomah (Piptadenia africana), the oil-bean tree (I'cntaclethra macrophylla), and a species of Brachystegia; the wood of all of these is difficult to split into billets. The total area of the concession amounts to 100 square miles, so that at the rate of clearing for fuel of six square miles in ten years the felling rotation will be sufficiently long to enable the coupes first made to be reclothed with forest capable of being utilized again for firewood, and also to furnish timber of a fair size $\left(4^{\prime} 6^{\prime \prime}\right.$ to $6^{\prime}$ in girth) for other purposes. 
The old coupes are being gradually covered by young tree growth, but the process is slow owing to the rank crops of the "Umbrella tree" (Musanga Smithii) that quickly occupy the cleared areas and keep back the growth of more valuable species. The Company contemplate getting out an expert to manage the forests of the estate leased to them, and they propose starting plantations of rubber, cocoa, \&c., as well as exploiting the more valuable timbers; for the latter purpose the excellently well-laidout system of light railways of 24 -in. gauge, with the highly efficient little locomotives that are in use on them, will prove invaluable. The general manager of the mines, Mr. McTear, very kindly took us round the workshops, saw-mills, \&c., and also to the place where the fellings are being carried out this year. The whole organisation of the mining work appears to be very efficient, complete, and self-contained.

Between the concession and the Adra River the country is woll farmed, but broad belts of forest intervene, and are rich in both mahogany (a new species of Khaya) and cedars. One magnificent example of that fine timber-tree, the Odoum (Chlorophora excelsa), was seen. The hills round Oboase are clothed with high forest containing two species of Piptadenia, Khayas, cedars, the Offram, and Sterculia cordifolia, as well as the gum copal tree (Cyanothyrsus ogea); the Odoum is also common. We next examined the forest situated in the fork formed by the junction of the Adra River and the Offin River, as far northwards as the town of Mansu Nkwanta. As it is proposed to take up a suitable area in this locality for a reserve, the forests were examined in some detail.

The land close to the junction of the two streams is low-lying and subject to inundations during the flood season; even during the dry weather it is marshy and overgrown with canes (species of (alamus and Ancistrophyllum) and the tombo or bamboo palm (Raphia vinifera). Similar wet depressions are found in the vicinity of the junctions of the smaller feeders with these two main streams.

Proceeding northwards from the confluence, the ground gradually becomes broken and hilly, till within a few hours' journey of Nkwanta the ridges culminate in peaks 1,000 to 1,200 feet in height.

'T'he vegetation, except that occupying the marshes, is of the irregular, high forest type, mostly evergreen, but with a fair sprinkling of deciduous-leafed trees. In the alluvial depressions that are not miler water during the dry season a few mahoganies (new species of Khaya), cedars (Psendocedreld cylindrica, and another species, the Tiama-Tiama), a large-leafed Kishia (Sarcocephalus sp.); Odoums, Offrams, Dahomahs, \&c., are to be met with, as well as the common silk-cotton tree, Eriodendron anfractuosum, Alstonia congensis, and rubber vines such as Landolphia oncariensis and C'arpodinus hirsuta. The undergrowth is very dense and tangled, consisting to a large extent of climbing and scrambling plants. 
T'he best forests, however, are found on the higher ridges further northwards where they have not been farmed. They contain the ordinary Khaya of the Gold Coast-apparently a new species-two species of cedars, both of which are new; numerous Bakus (Mimusops Djare), Odoums, Piptadenias, the incense tree (Santiriopsis Klainei), the gum copal tree (C'yanothyrsus ogea), Kokoti (Pynaertia ealaensis), Parkia biglobosa, Chen-chen (Antiaris toxicaria var. africana), the Waw-waw (Triplochiton Johnsonii), the shingle wood tree or Offram (Terminatia sp.), the O) wama (Ricinodendron africanus), and the Emril (Terminalia sp.), another shingle wood tree.

In the extreme northern portions of the tract of country now being dealt with, the forests assume a rather drier character, and deciduous-leafed trees become more numerous; they comprise two species of Albizzia, Sterculia Barteri, S. cordifolia, S'. tomentosa, Cola Afzelii, and a species of Pterocarpus. The tree, however, which is most characteristic of these northern forests, and which makes them so raluable, is the indigenous rubber plant, Funtumia elastica. It is extraordinarily abundant about here, more so than I have found to be the case anywhere else, and I very much doubt if the whole of the rest of tropical Africa can show such a rich forest in that species. It grows at its best in the drier portions of the evergreen forests, where the underwood is more open and species of trees with deciduous leaves far from uncommon.

A large number of the rubber trees have been killed or severeiy damaged from over-tapping, and it was a pitiable sight to see the forest paths in some places literally strewn with the dead stems of this species. Experience has convinced me of the fact that Funtumia elastica is much less resistant to injury caused by tapping than almost any other species of rubber-yielding tree. The wood is very soft, and decays rapidly from fungoid infections when exposed to the air. Once decay sets in the tree is easily overthrown during the tornado season.

For these reasons the tapping of this species has to be carried out with the greatest care and at comparatively long intervals of rest.

Notwithstanding the large number of trees that have been killed, there still remain an enormous number of fairly healthy plants that should, with care, give handsome annual return. Perhaps the best rubber forest is situated between the village of Yapiakrom and Odumase, on the Yapiakrom-Odumase-TakoraAdubia-Nkwanta road.

\section{The Forests North of Mansu N'Kwanta.}

These are situated to the south-west of Kumasi and extend northwards as far as the main Kumasi-Bibiani road. They are traversed from north to south by the $N^{-} K$ wanta-AmanchiaImpasatia road. With the exception of a ligh and important rauge of hills, situated a short distance to the north-west of 
Mansu-N'Kwanta, the country is undulating and broken only occasionally by well-marked ridges. The northern spur's of the main range extend a long way into the plains and broaden out into small plateaux which are, I should think, about $1,000 \mathrm{ft}$. above the sea and some $600 \mathrm{ft}$. below the crest of the water-parting. The village of Amanchia is situated on one of the flat spurs. The climate here is dry and bracing. With the exception of the main range, which is covered with the densest of evergreen forest, containing a fair sprinkling of mahoganies, cedars, odoum and baku, the bulk of the vegetation consists of the mixed deciduous type, and it gradually gets drier and drier northwards as one approaches the Kumasi-Bibiani road. The streams draining this northern portion were quite dry at the time of our visit, and water was difficult to find even after digging. As a general rule the forest has been destroyed within a radius of a mile or so of the more important villages for farming purposes.

On the main range itself (the $N^{\prime} \mathrm{K}$ wanta Bepo) clearings have, I am sorry to say, been made right up to the crest of the ridge by the inhabitants of Adu-Kuma. This should be stopped, as some of the most important feeders of the Offin liver rise in those hills, and the country already shows signs of drying up. There is ample suitable land at the foot of the hills available for cultivation. The hills are sclected in prefercnce on account of the richer soil that underlies the moist evergreen forests clothing them. It is just this deep layer of humus in conjunction with the roots of the plants growing in it that serves as the regulator of the watersupply, and is destroyed by farming.

The forests north of the main range belong, as mentioned above, to the mixed deciduous type in which trees such as the Waw-waw (Triplochiton Johnsonii); the Offram (Terminalia sp.); the Emril (Terminalia sp.); the Dahomah (Piptadenia africana); the Owama (Ricinodendron africanus), Albizzia fastigiata, Albizzia Brownei, the Odoum (Chlorophora excelsa), the Tiama-Tiama (Peudocedrela sp.), the Punkiwa (Pseudocedrela cylindrica), the Sumanta (Xylia Evansii), Sterculia cordifolia, S. Barteri, $S$. tomentosa, and a large species of mahogany (Khaya (inthotheca) with a light-coloured bark and wood, form the dominant species. The ordinary Gold Coast mahogany (another new species of Khaya) is also found about here in small numbers. A species of Pterocarpus of lofty growth was seen in these forests for the first time.

Between Tokorase and Mansu N'Kwanta the forests have been much destroyed for farms, but belts are left intact herc and there. They consist of irregular high forest, very rich in Funtumia clastica, and contain a few cedars (Pseudocedrela sp.) and the ordinary Gold Coast mahogany (Khaya sp.).

Other specics met with were Piptadenia africana (very common), the IVaw-waw (Triplochiton Johnsonii), common, the Odoum (Chlorophora excelsa), common, and the two shingle-rood trees, the Emril and the Uffram, both of them species of Terminalia. 
The marshy hollows between the hills contained thickets of canes (Calamus and Ancistrophyllum sp.), and the tree Alstonia congensis, from the soft wood of which the bulk of the Ashanti stools are manufactured.

In the neighbourhood of Edubia some fairly highhills $(1,200 \mathrm{ft}$.) were seen. Those close to the town had been cleared of forest vegetation right up to the crests and planted up with crops of banana and koko yams. Whilst at N'Kwanta I took the opportunity of liscussing forestry matters with the chief, and advised him to insist on the rubber tappers being more careful in their methods of tapping the trees and coagulating the latex.

As regards the question of taking up a forest reserve in the country situated in the fork formed by the junction of the Offin and Adra Rivers, there are several objections to acquiring an extensive area for that purpose. The country is full of small hunters' villag'es, and is much cut up with their farms, and is comparatively poor in the more valuable timber trees, such as the mahoganies and cedar's. Unless the inhabitants of these villages are compensated and removed to another locality, the exclusion of the farmed lands and village sites will necessitate the adoption of very irregular boundaries to the reserve, and they will in consequence be difficult to patrol.

It should, however, be possible to acquire one or two small reserves, consisting of a few square miles each, in the richest rubber forests. The object of reservation would be the protection and improvement of what are without doubt some of the best rubber forests on the coast. The natives owning the land should share with Government any profits arising from the sale of rubber or other forest produce collected in the reserres, the management of which should be undertaken departmentally.

Suitable areas to choose from are the rich forests situated between the villages Yapiakrom and Odumase and those to the north of Tokorase. The actual selection will have to be made with care, and in consultation with the native chiefs, and will require more time than we were able to spare. This matter should stand over till a Forest Officer has been appointed to the Gold Coast. For the piesent it is sufficient to have pointed out the most suitable localities.

The new white mahogany (the Kwabaho of the Ashantis) was a great find, and now makes the fourth species of $K$ haya known to me. It is quite common in the drier portions of the mixed deciduous forests, and amongst the more valuable timber trees is the most characteristic species to be found in that sub-type. It attains good dimensions and has a very large capsule.

The dominance of trees such as the Waw-waw, Owama, the Albizzias, the Sterculias, the Odoum, the Tiama-Tiama, the Samanta, and the white mahogany becomes accentuated in the drier portions of the areas clothed with forests of the mixed deciduous type. They become so common here and are such a characteristic feature that it is almost advisable for purposes of 
classification to transfer these comparatively dry forests into a sub-type of their own.

The forests between Impasutia and Bibiani.-They are rely extensive, and for the greater part consist of the type noticed above. For some distance on either side of the Offin River, however, they become much moister and belong to the ordinary evergreen type in which several tiers of vegetation are found.

The first half of the journes, between Impasatia and Adiemra, a matter of some ten miles, was through dry forest of the mixed deciluous kind. The overwood consists of trees of lofty growth placed rather far apart, and beneath it comes practically only one tier of undergrowth, the leaf canopy of which is complete. The stems of the undergrowth are straight, and they are sufficiently spaced to enable one to see some distance through the forest. The latter is one of the richest in valuable species that I have ever seen. Two species of mahogany, the ordinary one and the white kind, as well as two species of cedars (the TiamaTiama and the Punkwa) are extraordinarily abundant about here, and for miles the path was literally strewn with mahogany seeds. Another good timber tree, the Odoum (Chlorophora encelsa), is also plentiful, and considerably enlances the value of the forest. The latter is continuous with the dry forest north of N'Kwanta, and contains the same dominant species. They together form a most extensive and valuable forest, which the Administration should make every effort to protect. Villages fortunately are comparatively few and far between, and should not seriously interfere with reservation. There is one drawback, however, and that is the scarcity of streams sufficiently large to float out the heavier class of logs. Those we saw may of course be capable of doing so when in high flood, but they are certainly not capable of being utilized for that purpose in the dry season.

Good timber is plentiful enough, on the other hand, to make it worth while to construct a light railway for its extraction, and, as forests quite as rich as this one in every respect are met with all along the road to Bibiani, an important gold mining centre which is at present cut off from the railway or any navigable rivers, there appears to be further inducement to undertake a work of that kind.

West of the Offin River. as far as Yenebin, the forests are slightly moister, but they are still very rich in mahoganies and cedars. I third very fine species of the latter, that reaches an immense size, made its appearance for the first time. It is very plentiful and seeds freely, the path being frequently strewn with its huge capsules and seeds. The species loses its leaves in the dry season and appears to be new to science. It seems to be closcly related to Pseudocedrela utitis, from Uganda. It is known to the Ashantis as the Effuo Konkonti. These forests again are well worthy of reservation; they are drained by two important feeders of the Offin that are sufficiently large to be utilized for extracting timber.

Betreen Yenabin and Bibiani the forests continue to maintain their excellence, and in the more hilly parts species such as 
the Baku (Mimusops Djave) and Kokoti (Pynaertia ealaensis), which I had not seen for some time, made their reappearance. 'That valuable tree, the Odoum (C'hlorophora excelsa), that furnishes the best all-round timber to be found in tropical West Africa, is very plentiful. The silk rubber tree (Funtumia elastica) is also found in fairly large quantities, and, taken all round, I think that in number and variety of valuable trees these extensive forests of Western Ashanti will be hard to match anywhere in Africa. Moreover, the undergrowth is not so dense as that prevailing in the evergreen forests to be met with near the coast, and in consequence the natural regeneration of the more important species is far more satisfactory, and the gaps in the various age gradations less pronounced. They have so far not been touched by the timber traders, and except for clearings made for farms, little or no damage has been done to them. Villages are not numerous about here, and the inhabitants of some of them have one very good custom that greatly diminishes the damage done to valuable timber trees when the forests are cleared for farms, viz., the habit of leaving the larger mahoganies and cedars as standards on the cleared areas.

Extensive reserves should be taken up on this side as soon as possible, and strictly protected against farming. If the native chiefs and communities are paid a share of the profits arising from the exploitation of timber and other produce, no great difficulty should be experienced in setting these areas aside as forest reserves. The tract of country under forest is considerable, and probably exceeds 400 square miles; so there is ample wooded land available for cultivation as well. A special effort should be made at an early date to protect the richest portions, before they are invaded by new settlements.

\section{The Forests between Bibiani and Mim.}

\section{(Tano River Drainage.)}

Leaving Bibiani on the 30th March, we proceeded to Mim, viâ the Bibiani-Aliraso-Ka Krom-Gose road. Between Bibiani and Ahiraso a high range of hills intervenes, after which the path follows close to the left bank of the Tano River which is crossed at Tanoso. From here onwards as far as Mim the country, though broken, has no very high hills dominating it, and is characterized by the extraordinary abundance of its water supply. Pereninial streams are met with at frequent intervals along the way to that town. The well-rlefined range of hills close to Bibiani is covered with high forest, in which the ordinary Gold Coast Khaya and another species with large leaves, closely related to, if not identical with, $K$. grandis, are very plentiful. Other species of trees noticed were the Punkwa and Tiama-Tiama (species of Pseudocedrela), both common, the gum copal tree (Cyanothyrsus ogea), the Kokoti, Baku, Odoum, Kishia, Afzelia africana, Sterculia Barteri, and Sterculia tomentosa. The undergrowth here was thin and comparatively fres from climbers. In the swampy depressions to the north-east of the 
range of hills, close to the Tano River, the Tombo palm (Raphia vinifera) and a species of Calamus (rattam) are very numerous. The forests throughout are fairly rich in Funtumia elastica.

Between Ahiraso and Ka Krom, along the alluvial and somewhat swampy depressions bordering the Tano River, both Khayas and P'seudocedrelas are extremely abundant, more so than $\bar{I}$ have seen anywhere else in West Africa, excepting perhaps on the lower slopes of the hills surrounding the sacred lake Bosumtwi (about 30 miles south-east of Kumasi), where almost pure patches of Khaya grandis are to be met with. 'Trees such as Stcrculia cordifolia, S. tomentosa, and Afzelia africana have become more abundant in these forests, whilst Musanga Smithii and Piptadcnia africana are decreasing in numbers and size.

The forests contain several species of Monodora and also the rubber-vine Landolphia Thompsonii. In the neighbourhood of the various streams the forests are much moister in character than they are on the higher intervening ridges, which are the areas on which the most pronounced changes in the regetation have mainly taken place. Here the large-capsuled cedar (Pseudocedrela utilis?) is so plentiful that it is to be reckoned, together with the Sterculias and Odoums, as forming one of the dominant species.

Two specimens of the Borassus Palm (Borassus flabelliformis, var. Aithiopica), that have been planted in the village of Gose, were seen for the first time since we left Sekondi, where the species is common on the grass lands close to the sea.

In the moist belts of forest growing along the numerous streams that exist between the last named village and Mim, the usual species inhabiting the tropical evergreen forests are to be met with. The mahoganies and cedars are still abundant about here. They are associated with the Offram, Odoum, gum copal tree, Albizzias, Piptadenias, Eriodendron anfractuosum, species of Strophanthus, a Peltophorum that grows to a large size, and with the oil palm. The Sterculias and Afzelia africana are practically confined to the drier ground on the ridges.

The undergrowth of the evergreen belts of forest is very dense and contains, amongst other species of small trees, large numbers of the Carapa guianensis, the fruit of which is rich in vegetable oils. The timber also has a good reputation in Senegambia. In these forests of Ashanti, however, it scarcely attains the dimensions of a timber tree.

At Mim we got into the drainage system of the Bia River. It is said to flow through country that is corered with extensive and dense virgin forest, the best parts of which are situated due west of Min. Owing to the difficulty we experienced in getting guides from the chief of that town ond the disobliging attitude shown by him in general towards our proposed scheme of exploring these forests, we were, much to our regret, forced to abandon the idea of examining them. The locality is practically uninhabiter, and without his ready co-operation in procuring supplies for our carriers the trip would have proved a failure. As it was, we had great difficulty in getting enough food for our 
men even during our short stay in the town, which is a large and influential centre, and, I should imagine, capable of supplying abundant food. However, we had the consolation of passing through a very similar (so we were informed) tract of uninhabited country, that was clothed with what is practically virgin forest, during our journey to Mohang. These forests are described below.

\section{The Forests of the upper portion of the Bia River Drainage.}

From the town of Mim to within a few miles of Pamo the country is corered with an almost continuous stretch of high forest that appears to be more or less virgin in character. In the neighbourhood of Kenyase Mohang a few clearings and patches of secondary growth are to be met with; otherwise the forests have been left intact, and extend with but few interruptions right up to the zone of country forming the borderland between the areas occupied by the mixed deciduous forests and the open Savannah forests met with in north-western and northern Ishanti.

The country is hilly in character with a few well-pronounced ranges forming the divide between the basins of the Tano and Bia Rivers. 'They do not, however, reach an altitude of more than a few hundred feet above the main valleys, and have no very marked influence on the vegetation with which they are covered.

The soil is more loose in character and covered with a deeper layer of humus than that noticed during the last few days between Bibiani and Mim, and the rocks are of much older type, consisting mostly of schists and granites. Between Mim and Kenyase Mohang several important feeders of the Bia have to be crossed. They are all of them perennial streams containing much water. The neighbourhood of that river is very swampy, and the crossing difficult in consequence. From the opposite bank the country appears to rise very gradually up to the low plateaux of the open country. Water is as scarce on this side of the basin of the Bia as it is plentiful on the left bank drainage.

The well-watered condition of the Bia and Tano River basins about here appears to be mainly due to the fact that those two rivers rise on the south-western slopes of the high ground forming the edge of the Hinterland plateau, where, on account of the elevation of the land and the aspect of the slopes (facing the direction of the south-west monsoon), the annual precipitations must be heavy. No doubt the presence of rery extensive forests in that direction also accounts in part for the abundant water supply.

The right bank drainage area, on the other hand, of the Bia River is not only very much smaller in extent, but it is fed from the eastern (protected aspect) slopes of the important and high range of hills that run close to, and almost parallel with, the eastern boundary of the Irory Coast for a very long distance. This backbone, as it were, of the country runs practically north and south, and its western slopes intercept the larger portion of the monsoon rainfall. 
'This distribution of the annual precipitations has made its effects felt on the vegetation clothing these two portions of the basin of that river, with the result that in the former (left bank drainage) there is a tendency, despite the generally drier strain running through the forests, for them to revert, especially between Mim and Kenyase Moliang, where the streams are all crowded together within a comparatively short space, to the moister evergreen type in which Pseudocedrela utilis, and another species, the Tiama-Tiama, of the same genus, together with the ordinary Khaya (J)ubini of the natives) as well as Khaya anthotheca, are still to be found.

Other spccies noticed were the Offram, Odoum, Kokoti, and a few Piptadenias. Ov the right bank drainage, however, and even in the dricr portions of the left bank side, species such as the Duakobin, Afzelia africana, Sterculia Barteri, S. cordifolia, $S$. tomentosa, Albizzia Brownei, and another species, Xylia Evansii and Tetrapleura Thonningii are very abundant. From such areas the Khayas have practically disappeared, and Pseudocedrelas are only found here and there as very subordinate members of the forest regetation.

Funtumia elastica is still found scattered about the forests, but not in any large numbers. Rubber-yielding vincs such as Carpodinus hirsuta, Landolphia owariensis, L. Thompsoni, and another species occur pretty frequently in the more open portions of the forest.

\section{The Forests at the Head-waters of the Ba River.}

Between Techerabini and Pamo another water-parting is crossed. It divides the basin of the Bia from that of the Komoe River, the latter being the most important river draining the eastern portions of the French possessions on the Ivory Coast. One of its large feeders, the Ba River, rises on the main ridge refcrred to above as forming the backbone of the country about liere, and it was this portion (at the head waters of the $\mathrm{Ba}$ ) of the Komoc system that was traversed by us in our journey from Pamo to Puliamo. The divide is ascended very gradually, and one hardly realises from the general character of the country that an important watershed is being crossed.

The difference in the forest vegetation, however, became more pronounced, and we at last entered the typical mixed, deciduous forests as found in those portions of tropical West Africa with which I am acquainted. The chief characteristic of this type is the rather high pcrcentage ( 25 to 50 per cent.) of leaf-shedding trces to be met in it. Not only do new species with the deciduous habit make their appearance, but some of the trees ordinarily met with in the moist crergreen forests, where they are mainly evergreen in habit, become more pronouncedly leaf-shedding; the result is that these mixed forests, in the dry season especially, acquire that peculiar patchy colour of grays intermingled with various shades of green that is so noticeable in this type, the gray colouring being due to the leafless crowns of trees that have acquired the deciduous habit. 
The main factor determining the prevalence of any one type in a particular locality is the amount of rainfall and its clistribution through the rarious seasons of the year. Where the dry season is long and promounced the majority of the plants have acquired a rery marked deciduous habit, even when the total rainfall is otherwise heary.

Secondary (edaphic) influences are brought about by the character of the soil, and mainly depend on its capacity for retaining moisture. These influences become very important, howerer, in districts where the total annual rainfall is small, say 40 inches or less, and give rise to the most pronounced types of dry regetation (xerophilous thorn scrub and dry open savannahs) to be met with in the Hinterland.

In Western Ashanti the transition between the moist, tropical erergreen forests and the mixed, deciduous ones is rather grarlual, and spread over a comparatively large extent of country; abrupt changes such as are to be found in the neighbourhood of the high hills of Kwahou and the plains situated to the north and east are not experienced here, where the hills are of insufficient altitude to bring about important differences in the amount of rain precipitated. Nevertheless, even in Western Ashanti the presence of the hills has, to a certain extent, affected the general prevailing type of forest found there, and resulted in a distinctly moister strain of regetation in localities which would otherwise, on account of their greater distance from the sea and the consequently diminished force of the monsoon currents, be clothed with much drier forests than is actually the case.

In proceeding from Puliamo to the north towards the Volta River the struggle between the different types to gain the ascendancy is very noticeable, and it is just along the borderland, as it were-that is, along the belt of country between Puliamo and Braha where the conditions are, so to say, unstable-that every little advantage in increased moisture and favourable conditions of soil is eagerly sought for by the mixed deciduous forests, and the struggle is most keen; about here rerersions from the mixed deciduous type to the open, dry, savannah forests are frequent till the country gradually passes into one possessing a small rainfall, when, these conditions being the most farourable for the latter type, the mixed deciduous forests give way to the open, savannah ones, and are henceforth confined to narrow straggling belts aloug the water-courses and swamps.

As compared with the mixed, deciduous forests of Central Burma and the Central Provinces of India, the West African type contains on the whole a larger proportion of evergreens, and is more closed, and hence the transition from it to the savanuah forests is rather more abrupt than it is in those parts of Asia.

Between Techerabini and Pamo an extensive patch of grass land was met with for the first time. It was surrounded by mixed deciduous forest, in which far and away the most dominant species is the Duakobin (Afrormosia laxiflora), a large leguminous tree with a rery conspicuous red bark that peels off in large 
flakes and leares the under portions, which are of a yellowish white colour, exposed. The timber is yellow, and resembles satin wood in grain and lustre. Specimens of the wood of either this species or a closely related one from Southern Tigeria have, when figured, commanded very good prices in the home market, as much as $S d$. per superficial foot. The Duakobin is one of the numerous species of timber trees that holds a rery subordinate position in the moist, tropical evergreen forest close to the sea, and yet comes to the front as a dominant species in the drier mixed deciduous forests. It is found in small numbers throughout the moist forests of Ashanti and in the Trestern Province of the Colony.

Associated with this species in the mixerl, deciduous forests are Iylia Evansii (very common), Afzelia africana, Albizzia, Brownei, A. fastigiata, Chlorophora excelsa, Terminalia superba, Sterculia cordifolia, Triplochiton Johnsonii, Pynaertia ealaensis, the Emril (Terminalia species), Eriodendron anfractuosum, and in the moister portions a few Funtumia elastica. Some of the villages we passed through on our way to 'Tuna had their houses thatched with grass-a sure sign that the open savannah forests were not far off. One very extensive patch of grass land, containing sereral examples of a tree, Titex megaphylla, was seen close to the latter village. The last but one of the more extensive belts of evergreen forest (growing on well-watered, alluvial soil) was passed through duriug this portion of the journey. It contained some enormous Pseudocedrelas and a few Khayas, as well as the usual species found in such forests.

One of the most noticeable features about this belt of evergreen forest was the plague of thousands of blood-sucking flies (species of Haematopota) that settled on one in swarms and drove ereryone, including the carriers, nearly mad with their bites. They were two species-one black with some white on the wings and legs, and the other a pale brown. The former was met with in small numbers in the forests of the Bia River basin as well, and the latter extends into the dry, open savannah country during the rainy season. But nowhere else have I found both species so numerous and such a nuisance as they are in the evergreen belt mentioned above: unlike the tsetses (Glossina) and flies of the genus Tabanus, they are very soft, and at once succumb to the lightest rressure or knock.

Between Tuma and Puliamo we crossed alternate belts of forest and open sarannahs, the former covering as a rule larger tracts of country to begin with and then gradually getting smaller in extent till close to Puliamo, where it gives way to an extensive pateh of open savannah country some few square miles in extent. Here we found in plares Acacia Catechu, J)ichestachys nutans, Entada roudanica, Titer cuneuta, and a dwarf species of Ficus. The forest belts contained Exindendron anfractuosum, Afrormosia larifora, Tylia Evansii, Chlorophora escelsa, Terminalia superba, a species of Pseudocedrela, Sterculia cordifolia, and Cola Afrelii.

We obtained very fise riews of the high range of hills to the west, aloug the Frencl, horder, from this open country. 
For a few miles to the north of Puliamo (Jopakrom) the country is still drained by the Ba River, the sources of which are situated on a prominent range of hills situated to the north-west of that village: the path to dsare skirts the eastern slopes and spurs of this range, and passes through for about six miles a large helt of tropical evergreen forest-the last important one that we saw till we turned southwards from Kintampo and entered the forest region again some four marches from Kumasi. In this evergreen belt, which was confined to some rery moist, wellwatered allurial soil along the rallers of the eastern slopes and foot of the hills, a great number of plants that we had not seen of late reappeared. The most conspicuns were Piptadenia "fricona, Antiaris toricaria var. africana, the Tiama-Tiama (P'sendoredrela species), P'arlia biglobosa, the Raphia palms, and a species of Culamus. Alstomia congensis, Myrianthus arboreus; species of Anthorleista and Tetrapleura Thomningii were also seen.

Still further to the north this erergreen forest is replaced by the more open mixed, deciduous ones, amongst which patches of grass are frequent and forest fires had already made their appearance. This type of forest gradually gave way in its turn to the open sarannah forests (park-like country) of the Hinterland, which from liere northwards is the prevailing type. Shortly after learing the evergreen forest belt we passed over to the drainage area of the Volta River, the most important river of the Colony and Protectorate, and one which, strange to say, drains for practically the whole of its course the open park-like country characteristic of the Hinterland. Eren near its mouth I understand the country is deroid of any extensive belts of evergreen tropical forest.

\section{The Forests of the Volta River Drainage.}

\section{North-Western Ashanti.}

The typical open sarannah forests begin to form the dominant feature of the country in the neighbourhood of the small village of Asare, which is situated on the mestern Ashanti plateau. This plateau extends in the form of undulating land to within a few miles of the actual channel of the Tolta River, on approaching which a pretty considerable drop occurs.

The rolling, open country does not, I think, anywhere much exceed an elevation of a thousand feet above the level of the sea, but it is intersected in a north to south direction by two prominent ranges of hills which stand out well from the surrounding plains, and must, on their higher peaks at all events, attain an altitude of something like two thousand feet above sea-level. They are mainly romposed of schistose and granitoid rocks that have a shattered appearance and are lying about, piled one on top of the other in great confusion.

The two ranges are more or less parallel in direction, the one to the west follows closely the line of the French boundary and eventually becomes the range known as the Banda hills, whilst the other, situated some twenty to thirts miles further east, has its 
origin somewhere south-west of Braha, and running northwards past the rillage of Oboase gradually dwindles down to some low hills close to the Volta; it is broken through in one place by the 'I'omba River, a feeder of the 'Tain which, in its turn, is a tributary of the Volta.

The Tomba and Tain together drain the greater portion of the plateau crossed by us. At the head waters of the latter stream water is abundant, but further down their courses both rivers get rery dry, and water is confined to a succession of rocky pools. On the whole the water-supply of this part of the country is rery poor and precarious; the rillages have often to depend on wells dug in the beds of dried-up water-courses for their supply, and the whole region has a parched-up appearance, which is intensified at this time of the year (dry season) by the forest fires that were raging in all directions. The highest parts of the plateau, such as at Sikassiko, Braha, and Oboase, were exposed at the time of our visit to very strong, dry winds, that used during the night to rise to regular gales, eren when the sky was perfectly free of clouds.

As was to be expected from the arid conditions prevailing about here, the vegetation inhabiting it belongs to a markedly xerophilous type, which has been further intensified by the annual fires.

Generally speaking, the vegetation occurs in open formations, except in the immediate neighbourhood of the streams where the moisture in the soil has induced luxuriant growth and a reversion, according to the degree of moisture, to the tropical erergreen or mixed, deciduous forests. These latter ars, however, quite secondary features, and are confined to extremely narrow fringes along the water courses. In the driest localities the majority of the species become dwarfed, and some which are ordinarily found away from water courses in the savannah zone are now obliged to congregate along their banks, as the conditions become too dry even for them. This habit is most noticeable with trees like the true Khaya senegalensis (which is the dry zone species of mahogany) and the "Sass wood" tree Erythrophloenm guinernse. Though the formations are open it must not lye supposed that they are hardly worthy to be classed as forests, and contain few, if any, species of ralue to man. Extensive areas, more especially along alluvial deposits in the valleys, are clothed with open forests in which the trees are growing as close to each other as they are in a well-stocked orchard, and it is only the absence of a dense and tall undergrowth that enables one to see for any distance through them. In such places the growth of the trees is straight and tall: and above all the natural regeneration and condition of the age gradations is, comparatirely speaking, very satisfactory-in marked contrast, as far as the latter point is concerned, with what is usually experienced in the tropical erergreen forests, and even the mixed, deciduous ones.

Moreover, it is on just such areas that forest conservancy is most called for, and would have the best results on the water supply of the country and improved tree growth, providing, of course, fire protection is a prominent part of the programme. As 
regards species of economic importance, there are several of them helonging to the open savannah forests the timbers of which are of good quality and well suited for local use if not for export. Even for the latter purpose species such as the "dry zone " mahopany (Khaya senegalensis), the Opapao (Afzelia africana), and the " dry zone" cedar (Pseudocedrela Kotschyi), furnish woods that are well suited to the home markets.

On the borders of the mixed, deciduous forest belt, where the supply of moisture in general is not so poor, the savannah formations are confined to outcrops of laterite rock. It was on a succession of such outcrops near the village of Asare that we first came across the typical vegetation of the Hinterland which, as I am informed by my friend, Monsieur A. Chevalier, who possesses an univalled knowledge of the tropical West African vegetation as found in its native haunts, is identical with that of the Western Soudan.

From Asare northwards the savannah, forests begin to occupy the greater portion of the country, and the rocky outcrops are then inhabited by a very scanty dwarf vegetation, as they are, of course, in these still drier regions, the driest spots of all, from which the bulk of the moisture is rapidly evaporated or drained off after a shower of rain. Nevertheless, even here, small pools of water collect in the hollows eroded by the action of the roots of weeds, and these erentually become fairly large reservoirs of water that are generally occupied by aquatic plants. As a rule, however, they are quite empty during the dry season. Where extensive sheets of rock come to the surface they are often bordered by rings of evergreen vegetation that stand out in marlied contrast with the prevailing dry growth. The supply of moisture in the soil is abundant in such localities, and is due to the drainage off the sheets of rock. These spots are frequently occupied by large trees that belong, in habitat, to the leaf-shedding forest areas (mixed, deciduous forests), or even sometimes to the moist evergreen forests. Such examples show how all-important the influence of moisture is in determining the type of vegetation found in any one locality.

Great differences in the density of stock are met with in the savamnal forests. It varies from that of a well-stocked orchard to the very open park-like formations of the more arid tracts, and every intermediate condition is represented. The best growth occurs on rich alluvial soils along the valleys and lower flanks of the hills.

The trees typical of these savannah forests are:

The senegal rosewood tree (Pterocarpus erinaceus); Erythrina senegalensis (a small tree); the "Sasswood" tree (Erythrophloeum guineense), a species of Dalbergia, Parkia flicoidea (the locust bean tree), Albizzia angolensis, Detarium senegalensis (a good timber tree), Afzelia africana (which vields an excellent timber), Tamarindus indica, Entada soudanica, Entada abyssinica; Ormosia laxiflora, Acacia Sieberiana, Acacia Catechu, another species of Acacia close to $A$. nigrescens, Daniella thurifera (the "balsam copaiba" tree), 
Lophira alata, Vichrostachys nutans, Zizyphus mucronata, Hymenocardia species, Terminatia marroptera, a speetes of I'sorospermum, C'ola cordifolia, Adansonia digituta (Baobab trec), Eriodendron anfractuosum (the silk-cotton tree; occurs as a stunted variety in the typical savannahs): the dry zone mahogany (Khaya senegalensis), the dry zone cedar (Pseudocolrela Kotschyi), Blighia sapida (frequently cultivated), Parim. arium curatellacfolium (edible fruit), $\dot{P}$. Mobola (ditto), Anogeissus leiocarpus (the "chew stick" tree), Eugenia owariensis, (rossoptery Kotschyana, the shea-butter tree (Butyrospermum Parlii), Kigelia pinnata, Vited megaphylla, $V$. cuncata (fruit much sought after by elephants), Bridelia micrantha, a species of Antidesma, the fan-palm (Borassus flabelliformis var. aethiopica), the wild date pahm (Phonicreclimata), and a small species of spiny bamboo, probably Oxytenanthera abysinica.

Amongst shrubs and herbaceous plants the most characteristic species met with are :

The wild custard apple (Anona senegalensis), the Mexican poppy (drgemone mexicana, generally found as a weed in waste places near villages and farms), Cleome ciliata, Gynandropsis pentaphylla (also a weed), Cochlospermum tinctorium (very common), several fibre-yielding weeds belonging to the genera Sida, Trena, Hibiscus, Triumfetta (T. rhomboiden and T. cordifolia), and ('orchorus, as well as several species of Indigofera, Tephrosia, C'rotalariu, and Desmodium. 'The Combretaceate are represented by C'ombretum racemosum, ('. fuseum and ('. mucronatum; the Melastomaceae by Dissotis prostratu and Tristemma hirtum; the Rubiaceae by various species of Oldenlandia, Sarcocephalus esculentus (a dwarf form of the Kishia, a timber tree of the evergreen forests), and Gardenia sp. probably $G$. ternifolia (very (onmmon): the Compositae by various small weeds belonging to the genera Bidens, Termonia, Ageratum, Emilia, as well as Spilanthes acmella: the Aschepiadere by Calotropis procera; the Nyctagnaceae by Boprhania panculata and $B$. ascendens: the Euphorbiaceae by species of Euphorbia (the cosmopolitan weed, E. pilulifera, E. prostrata, and another very succulent prostrate form), Ployllanthus, and Vicrodesmis pulierula; the Taccaceae by Tacal: the Liliaceae hy Alor Barteri, Gloriose vireseens, Asparagus africanus, a species of Sanserieria, and Smilar Kranssiana, which from its straggling habit is a great nuisance, and frequently trips one up when walking through the open forests; the Orchidaceat by Lissochitus roseus, and L. Heudelotii; the Amaryllidaea by Crinum giganteum, species of Haemanthus and Hymenocallis senegambica.

The grasses are a very dominant type in these forests, and are represented, amongst others, by species of Eragrostis, Andropoyon, Panicum, \&c., and the Cyperaceae by Bulbostylis barbatu and $B$. lariceps.

One of the main distinctions between the mixed, deciduous forests and the savannah forests is the abundance in the latter of the grasses. Plants of that order occupy a very subordinate place in the former, whereas in the saramuhs they are far and away the dominant group, and play a very important part in 
suppressing, either by direct crowding or otherwise, the growth of more valuable species, especially timber trees. Throughout those portions of tropical Asia and Africa with which I am personally acquainted, the presence of grass in any large quantity is synonymous with the occurrence in the dry season of forest fires. Excepting in areas where fire protection has been a success, these fires, whaterer their origin is, may be looked upon for all practical purposes as one of the established natural conditions against which the regetation has to contend. Fortunately for the plants it so happens that the rery same contrivances and adaptations that enable them to successfully occupy such localities (that is, those in which the supply of moisture in the soil is deficient) also enable them to some extent to resist the injurious effects of the fires. Almost all the species inhabiting the zone of regetation exposed to this danger have dereloped an extraordinarily thick bark quite out of all proportion to the rest of the stem tissues. To prove this it is sufficient to select at random any two species, say one from the moist evergreen forests and the other from the dry open ones, when it will be found, quite nine times out of ten, that the latter has an absolutely (not merely proportionally) thicker bark. Again, some of the species of trees occupying fiery areas have enormously thickened roots (similar thickening, togecher with the formation of bulbs, \&c.. is a common adaptation amongst shrubs and herbs growing in dry soils) that, though woody, are of monstrous growth compared with the stems. Such nlants are cut down every year br the fires, but send up shoots and stems again during the rainy season, and so a struggle is kept up till the stems eventually reach a sufficient height to enable the crown to escape from the direct action of the flames. when a more rapid growth becomes possible. The loss in wood increment from such causes is very great. Plants accustomed to these conditions show extraordinary vitality, and it is often impossible to kill them except by grubbing up the roots completely.

Perhaps the hest example of an adaptation, amongst Vest African trees, to resist the arid conditions prevaiing in the savamahs, is shown by the baobab (Adansonia digitata, and some other species of the same genus), the stem of which is thickened to such an extent as to give it the appearance of a grigantic carrot. This derelopment is accompanied by changes in the wood tissues that enable the stem to function as a reservoir for storing water in, and thus to replace its loss from transpiration during the dry season of the rear. It is probable that a large proportion of the plants belonging to the savannal forests that mature their fruit during the dry season do so after the annual fires have passed over the land; enough statistics, however, have not been collected to establish this point.

The grasses, on the other hand, appear to sufter very little injury from the fires, and, if anything, seem to shoot up with renewed vigour very shortly after ther have been exposed to their action. Their main regetable period is, as a rule, earlier than that of the trees inhabiting the same localities, and is practically at an end by the middle of July. It begins at the end of March, immediately after the annual fires, and is completed in July. Thanks to the dispersal of their seeds by wind agency, as well as to the 
possession of rhizomes (underground stems) by many species, their powers of reproduction are something phenomenal, and they can eusily out-distance most of their competitors. Underground stems nust be a distinct adrantage as a protection against fires to those plants that possess them. The dried-up stems of the grasses form by far the greater part of the inflammable material on which the fires are fed, and in this respect alone their presence must have a very marked influence on the lives of the trees associating with them. Persons who have witnessed a savannah fire at close range, especially where the grasses are represented by gigantic forms such as Imperata arundinacea or Saccharum spontaneum, are alone capable of realising to their fullest extent the magnitude and fierceness of the flames. 'Those due to the burning of the ordinary layer of leaves found under trees with the deciduous habit are quite insignificant and negligible in comparison.

The exposure of the soil to the sun and hot winds after the fires have burnt off the protective covering of leaves and other vegetable débris, results in a deterioration of its fertility, which is further decreased when the rain from the tornadoes that immediately follow the fire season sweeps away the ashes into the nearest stream, and this process is repeated annually. Taken as a whole, the grasses, when existing in any large numbers, are a very decided menace to tree growth, both directly and indirectly. Woodland and grassland formations are always opposed to each other, and there is a continuous and fierce struggle between them to gain possession of the land.

In the "fringing" belts of regetation, which are invariably confined to the immediate vicinity of the watercourses, moist depressions, and swamps, certain species from the evergreen, moist forest regions near the coast make their reappearance not in the subordinate position in which they are usually found in the latter, but as dominant types. The most conspicuous examples amongst the trees are Carapa guianensis, Berlinia acuminata, Ricinodendron africanus, a species of $C y n o-$ metra close to C. Mannii, and Pterocarpus esculentus; whilst other species not met with at all in the evergreen coastal forests occur here: they are Mimusops multinervis (a good timber tree), an ebony (Diospyros mespiliformis), a small apocynaceous tree (Polyadoa nmbellata), and a species of Schrebera close to S. golungensis. A tree characteristic of the swamps in the dry open country is Mitragyne africana, a neal relative of which ( $M$. macrophylla) occupies similar localities in the forest region further south.

Of course, in addition to the above-mentioned plants, others common to both the erergreen tropical forests and the mixed deciduous ones are also found in the fringing forests. The most common are: Sterculia Barteri, Sterculia tomentosu, S. cordifolia, the Odoum (Chlorophora excelsa), the mahoganies, Khaya Punchii and Khaya grandis, the silk-cotton tree, Eriodendron anfractuosum, Cola A fzelii, Glyphaea grewioides. Tanthoxylum senegalense, Spondias lutea, Piptadenia africana, Terminalia scutifera, T. Brownii, Cassia fistula, Mimosa asperata, Albizzia Brownei. 4. fastigiata, Randia maculata, Usteria guineensis, and Spathodea campanulata. 
Further detail of the vegetation met with in the savannal country is given in the chapter dealing with the Afram plains (Volta drainage). Uf all the dominant plants inhabiting the tringe forests Carupa yuianensis has acquired, in comprarison with its growth in the moist coastal regions, the best development. It is now quite a respectable-sized timber tree. Rubber-rielding. rines, such as Landolphia owariensis, and others giving a less valuable product, such as L. Thompsonii, L. florida, and C'arpodinus hirsutu, are also met with in this type of regetation.

A rery noticeable feature about the trees inhabiting the open savannahs, more especially the drier parts, are the umbrellashaped crowus that they have developed, apparently with a view to offering as small a surface as possible to the action of desiccating winds. This habit is most pronouneed in the case of species such is Afzeliu africana, Erythrophloenm guinecnse, Acacia C'atechu, Entada soudanica, Khaya senegalensis, Maniella thurifera, Eriodendron anfractuosum, \&e., amongst which the two first-mentioned species are far and away the best shade-givers in a region that is mercilessly exposed to the fierce rays of a tropical sun.

'The Indian tamarind tree (Tamarndus indica) appears to be truly wild about this part of the Volta drainage, and occurs in belts and groups at no great distance from the watercourses; it does rot, howerer, invade the fringe forests. I have also seen fairly extensive forests of it close to the banks of the Okpara River, S. Nigeria, along the Dahomeyan border.

The baobab tree, on the other hand, is not really indigenous in any part of IVest Africa that I hare so far visited. It may be a native of the countries north of the tenth parallel, but wherever I have been it is always associated with human habitations, and its existence in any locality is a certain indication that the site is or was once occupied by villages.

Between Sikassiko and the Volta River at 'Tonkomia one frequently comes across the sites of deserted villages, the majority of which were abandoned on account of Ashanti raids, that are now occupied by dense thickets, in which Anogeissus leiocarpus, Acacia C'atechu, Entada soudamica, the silk-cotton tree, and groups of baobahs (Adansonia digitata) are the most prominent trees. One such thicket, close to the village of Braha, is periodi cally occupied by lions that make raids from there on the flocks and herds of the surrounding villages. We were shown the skins of some of these great cats that had been killed in the thicket by the native hunters.

The best type of open savannah forest containing trees of good, straight growth, is to be found along the valleys on both sides of the Braha-Oboase range of hills, where the soil is rich and comparatively moist. Some of the forests are well worth reserving, as they contain useful timber trees, such as Khaya senegalensis, Erythrophloeum guineense, Afzelia africana, Detarium senegalense, Lophira alata, Muniella ihurifera, and Psendocedrela Kotschyi in abundance, as well as the shea-butter tree (Butyrospermum Parliii), which, however, is almost universally distributed in the Finterland. The hills themselves are occupied witl 
stunted, guarled tree growth, which in many places has acquired the habit of Chasmophytes and Lithopytes. It is represented in general by the same species as occupy the valleys, but it is also rich in aloes, suceulent Euphorbias, and plants of the genera Ficus and Strychnos. The poor condition of the hill regetation may be attributed to the extremely rocky character of the ground and consequent scarcity of water.

Good open forests reappear in the ralley of the 'Tomba (Tomme of the maps) River, and again close to the Volta River before the final descent to the channel is made. The banks of the latter are, as usual, occupied by fringing forest. Magnificent park-like countryismet with on the high shelf of landskirting the right bank of that river. Thetreesabout here are of very fine growth, but they are widely scattered, and the intervals are occupied by grass. Cola cordifolia and a small dark-coloured Acacia, closely related to $A$. nigrescens, are common in this locality.

East of the village of Oboase the forests for miles are very stunted in growth, and water is extremely scarce in that direction. The banks of dried-up water-courses are occupied by thickets of a spiny bamboo that appears to be an Oxytenanthera, probably $O$. abyssinica. Here even such rerophilous trees as Khaya senegalensis and Afzelia africana are, on account of the dryness, forced to abandon the high parched-up ground and congregate together along the banks of the streams.

A few miserable Raphias, oil palms, and the wild date palm, Plocnix rectinata, are also to be met with in the same localities.

The fan palm (Borassus flabelliformis var. aethiopica) is not nearly as abundant in these sarannahs as it is on the Afram plains in the extreme north-eastern portion of the colony. Nevertheless it is sufficiently plentiful to form a prominent feature of the landscape.

The Volta River, where we crossed it, just below Tonkomia, is a magnificent stream nearly 400 yards across from bank to bank; just above and below this point, however, it becomes much narrower, and is confined for miles in a rocky channel. The fringe of evergreen vegetation is not as broad as one would expect from a river of that magnitude, but this is probably due to the very high and stony character of the banks, to which moisture cannot percolate during the dry season when the river is very low.

Low rocky hills are found along both banks of the Volta, and the rich allurial soil along the valleys between them is occupied by forests of superior growth.

Those passed through between Bian and Jugba (in the Northern Territories) are quite good and capable of vielding fairly large timber. Unfortunately the time at our disposal was too short to (enable us to make a tour through other portions of the Northern Territories, where, I understand, good forests exist, as, for instance, to the south-east of Bole and along the left bank of the Volta to the south-west of that station. If they are as good as those we saw during our marches from Tonkomia to Bery, then that portion of the Protectorate is to be congratulated on its posses. 
sions, for the forests we passed through were about as good of their kind as exist in the dry zone of the Hinterland. Here again reservation of the best wooded areas is very desirable, especially along the main lines of communication, so as to ensure a supply of timber for the various district headquarters' stations and the more important towns. The adoption of such measures would also be attended with the happiest results so far as the preservation and improrement of the water supply of the stations are concerned.

Near the crossing at Bery the evergreen belt is much broader and contains a fair quantity of either Khaya anthothera or Khaya grandis, as well as the Odoum (Chlorophora excelsa). From there the ground gradually rises up again into the Northern Ashanti plateau on which Kintampo, N'koranza, Kc., are situated. The final ascent is, in the neighbourhood of the former town, rather steep, abrupt, and very rocky. From the edge of the escarpment a splendid riew is obtained of the Banda hills and the country drained by the Tain River. As far as one could see the regetation appeared to be of the same character throughout the country embraced by the panorama, and is that typical of the savannah forests. The monotony of the colouring was relieved here and there by the dark green lines of the evergreen belts fringing the streams.

In the vicinity of Kintampo itself some rery excellent tracts of forest belonging to a sub-type that is rather rare were met with. They belong to the mixed deciduous forest formations, but are very open, and contain trees of lofty growth, amongst which nearly all the more important timber-yielding species of Ashanti are represented. They, of course, occur as broad fringing belts along the water-courses, and are confined to the richer alluvial soils.

In character they approach closely the better class of the mixed deciduous forests of Burma. They extend, with frequent interruptions, due to belts of sarannah forests intervening, right up to N'koranza, and must altogether cover an extensive area. Containing as they do well-grown examples of mahoganies, cedars, Odoums, Offrams, Mahomahs, Thaw-waw, \&c.., they are sufficiently valuable, at least the best of them, to be protected by reservation. One very important and excellent feature about them is the satisfactory condition of the age gradations, which. with proper treatment, would ensure a continuous yield of forest produce. The undergrowth, apart from the seedlings of the overwood, consists mainly of plant associations belonging to the natural order ficitamineae, which is here represented by various species of Amomum, Costus, aud Phrynimm: the latter furnisl: the leaves so much in demand for thatching purposes by the natives inhabiting the mixed deciduous zone of regetation.

As Kintampo is likely to become a very important hase for the stations in the western portions of the Northeru Territories when that country is more opened up, it is advisable to protect the best local sources of timber from damage by farming and indiscriminate fellings as soon as possible. The forests in its neighlourhood are capable of supplying timber of the very first quality and of large dimensions. 
From a professional point of view these very open, mixed deciduons forests ale much to be desired, as they are more amenable fo, and respond freely to, systematic management, and contain a greater proportion of useful trees per acre than do the dense, moist evercreen forests near the coast, in which only comparatively few out of the vast number of different species composing the growing stock are of economic importance.

The Kintampo and N'koranza forests require further investigation with a view to ascertaining the possibility of exploiting them for the home markets. Perhaps the Pru and other large feeders of the Volta River will prove to be of sufficient size and depth to float down large timber during the flood season. In Burma big logs are frequently exploited from extremely hilly, and even nountainous, country by taking advantage of the heary rises in the streams during the monsoons. It is wonderful what obstructions, of the nature of rapids and waterfalls, timber is capable of successfully orercoming without sustaining much damage if only the highest floods are utilised in floating it out.

After leaving $N$ 'Koranza we proceeded to Kumasi by the main Kintampo-Kumasi road, and very soon got into the moist, evergreen tropical forest belt through which the rest of the journey was performed. These forests differ in no respect from those we examined to the west of the capital of Ashanti on our way to Mim, and we therefore did not spend any time in specially investi- gating them. The last two marches were through country that has been extensively cultivated at one time or another, and contains some goor cola plantations. Nurseries of young cocoa plants were a constant feature of every Ashanti village that we passed through within the big forest region, and the same remark applies to the villages of Upper. Waw-saw and Denkira. The way in which the cultiration of this plant has been taken up by the natives throughout the most suitable localities in the Colony and Protectorate is perfectly astonishing, and shows what they are capable of doing, once they have had practical demonstrations of the financial success attending such enterprise.

We reached Kumasi on the 3rd May, 1908, and after spending a few days in arranging for our next trip and in visiting Captain Soden, the Acting Commissioner at Oboase, with a view to procuring information regarding the possibility of taking up a reserve on the Dampia hills, and in enjoying the kind hospitality of the Acting Chief Commissioner, Major Armitage, D.S.O., with whom I was able to discuss forest matters, Mr. Burbridge and I started on the 11th of the same month for our fourth and last trip through the Gold Coast forests.

Our late journey through the western and northern portions of Ashanti had shown us the immense and raluable resources of the country so far as forestry and agriculture are concerned, and had to me, personally, enlarged my ideas and experience of the forests of tropical West Africa.

\section{The Forests South-East of Kumasi.}

During a trip made to Kwisa (on the Cape Coast road), southcast of Kumasi, with a view to examining the forests situated 
between the Jym River and the Dampia range of hills, an opportunity was given of ascertaining the type of regetation to be found along that road as far to the south-east as the crest of the range of hills mentioned above.

Generally speaking, the forest growth met with contained but few species of any economic importance. The Odoun (Chlorophora excelsa), an odd cedar (Pseudocedrela sp.), the shedua or gum copal tree (C'yanothyrsus ogea), Funtumia elastica, the shingle tree (Terminalia sp.), and a few mahoganies (Khaya sp.), were the only valuable trees met with. Of these the Odoum and the Offram were far and away the most plentiful, and formed at conspicuous feature of the regetation.

The forests are of secondary growth, and are very irregular as regards the condition of the growing stock. They are much honeycombed with farms at the present time, and show abundant traces of having been subjected to the same treatment in the past. As usually happens in such cases, the clearing of the forests for farms and the subsequent relapse into "bush" of the abandoned (fallow) sites, has resulted in a few selected species of trees only becoming dominant in the secondary growth that springs up.

These selected species generally throughout the country consist of the Odoum (Chlorophora excelsa), Dahomah (Piptadenia africana), the Offram or shingle wood tree, the Emril, another shingle wood tree, Pentaclethramacrophylla, the Waw-waw (Triplochiton Johnsonii), and Ricinodendron africanus. These trees are left by the natives as "standards" "when they clear the forest for farms, and by a repetition of this process the dominance of the favoured species becomes accentuated as the felling rotafions increase in number, till in time the forest acquires the character of a wood that has been exploited under the " coppice with standards" system, the standards being composed of a mixed crop of the favoured species enumerated above, whilst the "coppice " consists of a very dense tangled mass of regetation formed to a large extent of climbers, such as various species of Landolphia, Carpodinus, Clitandra, Hippocratea, Strophanthus, Combretum, Acacia pennata, Acacia ataracantha, and shrubs and trees such as Karonga madagascariensis, Ramwolfia, Myrianthus. mboreus, the "umbrella tree" (1/usanga Smithii), Albizzias, and a host of other species. Amongst the dominant species of the overwood (standards) natural regeneration by seed is most successful in the case of the Waw-waw and the Offram trees.

Along the Cape Coast road, between Kumasi and Krisa, some excellent examples of this type of secondary forests are to be met with. The older forests are confined to the vicinity of the largest streams, as, for example, the Adra River, and to swampy areas, such as the swamps met witl between Dompoase and Fomena, where farming has not been much resorted to in the past.

Comparing these forests with those of the Western Ashanti that are situated on approximately the same parallel of latitude, the most marked difference between the two is the extraordinary abundance in the latter of species of cedars (Pseudocedrela), and mahoganies (Khayas). 'This, in conjunction with the fact that in places 
there is a decider tendency on the part of the natives inhabiting that side to firom trees of these two genera by leaving them as " stamdards " when claring the bush for farms, malies the forest areas of Western Ashanti far more valuable to the forester than those alome the ('ape ('oast road within the limits of area now being dealt with.

This state of affairs in south-east Ashanti is, howerer, by no mrans to be teplored. The people east of the railway are keen farmers, they have gone in extensively for cocoa cultivation in an area that appears to be eminently suitable for that plant, and they will reap the full benefits arising from the proximity of the railwar to their farms: in short, monder the circumstances, it is preferable in every way that this land should be taken up for agricultural purposes.

The farms belonging to the important town of Fomena extend for a long distance round that place, and the whole locality gives one the impression of being an excellent agricultural centre. The country is well watered, in fact exceptionally so, and should suit plant; such as cola and cocoa admirably.

I was glad to see that the cultivation of the indigenous rubber tree Funtumin elastica has also been taken up by the natives in this part of the country. In the wild state it is rather sparsely distributed about here.

\section{The Proposed Dampia Reserve.}

'This reserve was meant to include the area situated between the Jym Rirel and the erest of the Dampia range; it being bounded on the south by the boundary of the Ashanti Goldficlis Corporations land and on the north by the junction of the Moinsin hills with the Dampia range. From the Kwisa resthouse, which is situated on a high spur of the Moinsin hills, Mr. Burbridge, Curator, and myself, were able to obtain a rery good panoramic view of the upper basin of the Jym River and a portion of the forests that it was proposed to take up as a reserve. Excursions to the eastern watershed of that river, right up to the crest of the Dampria range and along it for some distance, as well as through the northern portions of the forests situated between the river and the hills, showed us that: (a) the forests are very extensively cut up with cocoa farms, some of which are actually situiter at the foot of the main range: almost all the villages situated along the right bank of the river possess farms within the area proposed to be taken up as a reserve; (b) plants of eronomic importance are comparatively scarce in these forests, which are particularly poor in the more important timber-trees such as the mahoganies and cedars; the Odoum (Chlorophora corcelsa) and the shingle wood tree, the Offram, are practically the nuly valuable timber-trees to be met with in any abundance: these two speries are, howerer, miversally distributed in Ashanti, and it would hardly be justifiable to take up a reserve hore solely becanse the forest is rich in them: the Pebedum (Lnima Ritaincana), a good timber-tree, is sparsely distributed about here: (e) the upper Trm River, north of the pointwhere the Cape Coast road crosses it, is scarcely of sufficient size to enable 
timber to be floated down it. This fact excludes for the present the advisability of taking up as a reserve the rather extensive forests drained by the upper reaches of the river where only a few villages and farms are said to exist.

The large number of farms in the lower basin of the river and within the limits of the proposed reserve would make it rery awkward to establish reservation here; this, coupled with the fact that the forests are poor in economic plants, that the ground is to a large extent swampy, and that owing to the steepness of the restern slopes of the hills but little other forest-corered land is available, induces me to recommend the abandonment of any scheme for forming a reserve here. Owing to the number of farms existing in the locality. the measure is certain to prove very unpopular with the inhabitants.

A well cut and graded mule path was found along the crest of the Dampia range; it was apparently constiucted by one of the mining camps (the abandoned site of which we visited) some vears ago, and is still in good order.

Though the forests under consideration are not worth reserving with the object of ensuring a continued supply of forest produce and improving the condition of the growing stock, yet the fact should not be lost sight of that on general principles alone it is highly important that the forests clothing the crests of the hills and the stcep slopes should be protected against farming in order to preserve the climatic factors of the country. This measure is in the interests of the farmers themselves as it ensures, apart from the existence of local swamps, the general water supply of the streams, prevents erosion of the hill-sides, and provides for barriers of forest vegetation against the spread of any fungoid diseases or insect pests that may attack the agricultural crops. It in fact helps to segregate the infected areas.

\section{The Forests between the Cape Coast Road and Lake Bosumptri.}

After leaving Kwisa we marched to Lake Bosumptwi by the Bojare-Dadiase-Bansu road, which passes through country that has been extensively farmed. In fact, with the exception here and there of narrow belts of secondary forest growth, most of the land is now under crops, such as cocoa, cola, yams, maize, \&c. Small plantations of Funtumia elastica have also been made in the vicinity of the villages passed through. The secondary forest contains the usual species common to the forests of Ashanti along this parallel of latitude. Odoum is common, and so is the shingle tree, the Offram; these, with a few cedars ( $P$ seudocedrela), are practically the only useful trees to be met with.

The hills bordering the southern edge of the lake are, however, more extensively wooded, and here cedars and mahoganies are more plentiful. One species of the latter, probably Khayo grandis, is very abundant along the southern shores of tire lake. A rough valuation survey made over 6.4 acres gave approximately an average of three trees over $4^{\prime} 6^{\prime \prime}$ in girth to the acre, a very high figure when the area covered by a mahogany tree is taken into consideration. The natural regeneration of 
Whis speies is also excellent along the cleared shores of the lake. lixtrusive patches of tall clephant grass have made their appearancer on the ralared slopes facing the lake, and as these patches aj)pear to be burnt every vear during the llry season there is somc dinger of denudation of the hill-sides eventually taking place, if the spread of the grass at the expense of forest growth is not rhecked.

The lake itself does not appear to occupy the crater of an ancient volcano as bas been suggested. I could find no trace of volcanic action anywhere. It is more probably due to the sudden subsidence of an upland valley; subsidence is still moing on, as is manifest from the dead trees to be seen standing well away from the shores in the southern end of the lake, and the encroachment annually of the water on the village lands at that $n d$. There is a marked rifference in the level of the surface of the lake in the wet and the dry seasons.

\section{The Forests between. Lake Bosumptwi and the Anum River.}

After leaving, by the Bansu-Odumase road, the steep-sided basin in which the lake is situated, we passed through open well-farmed comntry in which the usual "standards" such as the Odoum, Waw-waw, Offram, Emril, Eriodendron anfractuosum, Ricinodendron africanus, have been left on the farms by the natives. A few irregular belts of secondary forest containing some Khayas and Pseudocedrelas were also met with here and there, especially along the water-courses.

Tegetation and farms of this type are met with for some distance on the other side of the Anum River, which is still a large stream in this locality and quite capable of floating out the heaviest timber.

\section{The Forests between the Anum River and Odumase.}

After crossing the Inum River we ascended the low undulating plateau that forms the country to the east of the sacred lake. For the first hour the path led through open country that had been well cleared of forest growth for cultivation; cocoa farms extend on either side of the track for miles, practically, and are but little intermpted by belts of forest. The latter then become larger in extent and finally merge into a splendid old forest that is almost primeval in character. This forest is about 16 miles wide from east to west where we crossed it, and stretches southwards, I believe, for a long distance. It contains trees of lofty growth, the leaf canopy is almost complete, and in the dense shade that prevails the undergrowth is so sparse that one can see for 60 to 70 yards through the forest, and can walk freely about it without having to use the matchet.

It is greatly to be deplored that this magnificent example of tropical evergreen forest is so comparatively poor in trees of ernomic value: with the exception of a few cedars that were scen at long intervals and a mole plentiful supply of the Odoum there was nothing to be found there that is of much ralue at 
present. The ubiquitous Offram, of course, is greatly in evidence, and together with the Waw-waw forms the dominant species Both these trees attain far greater dimensions in this forest than I have seen anywhere else on the Gold Coast. Associated with them and completing the periplement of the arboreal growing stock are the following species, which also attain an immense height and are beautifully grown. They are the silk-cotton tree (Eriodendron anfractuosum), the Esea (Combretum sp.), the gum copal tree (Cyanothyrsus ogea), Antiaris toxicaria, Sterculia cordifotia, Sterculia Barteri, Santiriopsis Klainei, a few Khayas, some Kokoti and Baku, as well as Piptadenia africana, and an allied species with a much larger fruit. These, together with the Odoum and Offram, form nine-tenths of the tree vegetation.

The undergrowth chiefly consists of evergreen shade-bearing shrubs of species different from the trees forming the overwood; these shrubs are of remarkably straight growth, and are characteristic of the very old moods. The secondary or younger woods have a dense tangled undergrowth, consisting mainly of climbers and scrambling shrubs, and can thus be easily distinguished from the former.

Comparing this forest with similar old growth seen in Western Ashanti, one is at once struck with the peculiarity that the overwood in the forests just described is poor in variety of species and that the majority of the species that compose it are identical with those usually left as "standards" by the natives when the forests are cleared for farming purposes; hence the conviction is forced on one that, close as the resemblance of this forest is to the primeral type, it is really a secondary forest of very great age that has sprung up on areas cleared centuries ago for agricultural purposes. Waves of invasion and internecine warfare prohably depopulated the area and gave it the long period of rest necessary to develop the old growth now occupying it. The ownership of the area in question is, I believe, still disputed, and it is hence likely to enjoy a further spell of immunity against the farmer's axe. I also understand that it has been the policy of the Ashanti and some other tribes to keep intact broad belts of forest along their common tribal frontiers; these belts act as "buffers" in the event of invasion, \&c., and are also responsible for some of the older forests to be met with in the country.

Poor as the Anum forests are in useful timber-trees such as the mahoganies and cedars, nevertheless I would recommend their reservation, if merely for the sake of preserving one of the finest series of old forests in the country. There is ample forest-clad ground left in the vicinity to satisfy the wants of the most energetic farmers, and reservation would prove no hardship, especially as reservation in this particular locality would perforce be restricted practically to the prohibition of farming on the selecter area, and would not interfere with the use of forest produce for the domestic requirements of the inhabitants or with hunting.

Towards the north-eastern limit of the forest, close to the village of Mirefuaso, which is one hour's journey from Odumase, 
extensive cocoa farms have been established and extend for miles in that direction. The young trees appear to be doing remarkably well, and this locality will probably in a few years' time prove to be a very rich centre for that produce. The farming operations being carried out on this side of Ashanti are far in advance of anything we saw on the western side, and I am much impressed with the future prospect of agriculture in the country lying between the sacred lake and Kwahu. It seems to me a pity, however, that the farmers have, excepting the various food crops required for local consumption, practically put all their egres in one basket by confining their attention to cocoa and, to a small extent, to Funtumia elastica; cola, which promises a steady demand and a market that is unaffected by operations in Europe, would appear to be a very desirable crop to cultivate on a large scale, and it would increase trade generally with the northern territories.

Considering the value of agriculture to the country-and agriculture will endure when all the gold-fields have been exhausted -it would certainly be a very wise step if a large staft of travelling agricultural teachers were appointed and employed to wander round the country for the purpose of teaching the natives improved rethogds of cultivation and preparing produce for the export market, as well as to introduce new species of economic plants. The great danger of delaying such instruction is that incalculable harm may be done to the fertility of the soil unless a rational and well devised scheme of rotation of crops is adopted by the natives. Improvement of the soil means the use of artificial mannes which could not be placed at the disposal of natives out here except at a prohibitive cost.

Concurrently with the expansion of agriculture will begin the reduction of the forest areas, and with this reduction will follow the train of evils resulting from the destruction of the rooded areas-reduced rainfall, water supply. \&c., till a time will come when the farming rotation adopted by the natives will be so curtailed that the secondary bush, which is at present allowed to grow up on the fallow lands and which helps to replenish the fertility of the soil, will not have sufficient time within which to reach the age necessary to ensure this object. Hence the advisability of adopting a proper rotation of crops that will diminish the exhaustion of the soil to the maximum extent. The necessity for protecting a certain proportion at least of the wooded areas against the axe of the farmer will further curtail the land left at the disposal of agriculture, and thus eventually teud to a more intensive system of cultivation.

T may be pardoned for this digression on the agricultural policy to be adopted out here, but it must of necessity be so mutually interdependent with any forest policy chosen for the country that it is just as well to mention the broad outlines of their relations one with another.

\section{The Forests between Konliota and Bompata.}

The road between these two places passes through high forest containing a large number of old trees, the most important of 
which was the Odoum; this species is fairly plentiful about here. The country is rather hilly, and the valleys are swampy. Some farms were noticed on either side of the road, which was bordered for most of the way with a fringe of evergreen forest. Other trees seen were the Baku (scarce), Kokoti, a few Khayas, the Penkwa (Pseudocedrela cylindrica), and another species of the same genus with very large capsules. As usual the dominant species of trees consisted of the Offram, the Waw-waw, Sterculia cordifolia, and Stercuiia Barteri, the Esea, two species of Piptadenia, Ricinodendron africanus, Eriodendron anfractuosum, and Alstonia congensis. The oil palm is also met with in fairly large quantities.

Between Bompata and Akwasihu at the foot of the mountain system of Kwahu, we passed over very broken country which is, however, well wooded with fairly old secondary forest; cocoa farms are met with along it at frequent intervals. At the village of Prahso there is an excellent little plantation of Funtumia elastica, about seven years old; the plants are healthy and show very good growth.

The depressions between the hills are all of them more or less swampy and are occupied with the usual swamp regetation of tropical West Africa. On the hills we noticed some rich but restricted patches of the Okisibiri or flint-wood tree, that is used for mine props in Tarkwa and Prestea. We had not seen this species since leaving the hills of Wassaw. Cedars, both the Pentiwa and the large-capsuled species, were noticed along the roadside, and the forest consisted of the usual type to be met with in Eastern Ashanti. As we approached the high hills of $\mathrm{K}$ wahu, farms became more numerous, and the country became in consequence more open in character.

A large-leafed Khaya, probably Khaya grandis, was seen on the slopes leading up to the final escarpment of the Abetifi hill system. This escarpment is very steep, and stands up like a wal of sandstone facing the low country to the west and south-west.

The crests and summits of the Abetifi hills are comparatively flat, and in places broaden out into undulating plateanx that appear to be well suited as sites for the formation of sanatoria and the residence of Europeans.

The climate is delightfully bracing, and the difference in temperature between the tops of these hills and the surrounding low country is much greater than $I$ have experienced, for a similar comparatively small difference in altitude, in any other tropical country. The average altitude is about 2,000 feet, and the climate is similar to that which obtains at elevations of between 3,000 to 4,000 feet in Burma and Siam.

The hills have been extensively farmed, and several of the ridges in the ricinity of the large town of Obo are now corered with grass and low, scrubby oil palms; some fairly broad belts of forest, howerer, have been left intact on the higher and more exposed hills on which the sources of the numerous streams watering the country are situated. 
Taking everything into consideration this tract of country promises the best results so far as a suitable climate for the residence of Europeans is concerned. It is well watered; there is abundance of flat ground suitable as sites for stations and recreation g'rounds, and it appears to be free from the damp night mists that are such an objectionable feature of the Aburi climate.

As far as the forest vegetation is concerned there appears to be but little difference between that found on the hills and the ordinary evergreen forests of the plains. A species of Khaya with large leaves, probably Khaya grandis, is common about here, and so is the Odoum (Chlorophora excelsa). The cedars (Pseudoredrela sp.), on the other hand, are poorly represented.

()ther useful trees to be met with are the Offram or shingle-wood wee (Terminalia sp.), the gum copal tree (Cyanothyrsus ogea), and Cordia Irvingii, a species that yields an excellent timber, from which very durable shingles are manufactured.

The dominant species in these forests, however, are the same as those found in the evergreen vegetation of the plains, and consist of the Mahomah (Piptadenia africana), the Waw-waw (Triplochiton Johnsonii), Eriodendron anfractuosum, the Chen-chen (Antiaris toxicaria rar. africana), the Assomah (Parkia biglobosa), the Koloti (Pynaertia ealaensis), the Owama (Ricinodendron africamus), Stcrculia cordifolia, and Sierculia Barteri. A few wild examples of Funtumia elastica were also seen.

There appears to be a more pronounced difference in the herbaceous regetation, and many species of plants not met with in the plains were found here. The bracken fern, for instance, was seen on several occasions on these hills, as well as a beautiful little wild balsam (Impatiens sp.), and a species of Begonia.

The chief agricultural crops grown are maize, koko, yams, hananas, ground-nuts, and cocoa. Plantations of the last are, I believe, being rapidly extended every year, and this crop has already replaced the hill-rice that used formerly to be cultivated liere on a large scale.

\section{The Afram Plains.}

From Abetifi the plains situated to the north-east were visited. They are clothed with vegetation characteristic of the "dry zone." Belts of evergreen forest are, however, found along the immediate banks of the streams and in the moist depressions so often met with in this type of country. Extensive outcrops of laterite and schistose rocks are found scattered about the plains, and on them the regetation is of the most scrubby and dwarfed character.

The soil formed by the weathering of these rocks is nevertheless fairly rich, and supports good tree growth wherever it is moist and has accumulated to a sufficient depth. These rich patches of soil are usually met with just below the lower level of the "strike" of the outcrops, whilst narrower deposits border the channels of the streams. 
Generally speaking, these rich patches of moist soil, covered as they are with evergreen forest, form the actual sources of the streams draining the plain. Very few of the former, if any, are perennial, but their courses can always be recognised, even at a distance, by the evergreen fringes of regetation growing along their banks, the soil in such places being moist enough at the driest season of the yeur to support that type of regetation.

From the foot of the Abetifi hills, as far north at least as the Sumin and Bunda Rivers, the country is undulating in character with higher ridges separating the basins of the more important streams. Superimposed on these general features are numerous outcrops of laterite and schistose rocks, the latter of which often occur in the form of huge flat sheets (sometimes 200 to 300 yards in length, and 50 to 100 yards broad, and 10 to 20 feet high), arranged in successive terraces one above the other, like a gigantic staircase.

'The sheets of rock often contain fairly large circular or oval depressions that are filled with rainwater during the tornado season, and form pools that last well into the dry season. Waterlilies and other aquatic plants occupy them, and the corrosire action of their roots helps to further enlarge the depressions till they sometimes reach the dimensions of quite a respectable sized pond. A few of them are said to contain water all the year round.

The majority of the streams in this part of the country have their sources in these rocky pools, the overflow from which feeds the streams. For days after a shower of rain tiny rivulets continue to trickle off the sheets of rock down into the rich deposits of soil found at their bases, where moss and other evergreen vegetation covers the ground and helps to hold the water in suspension like a sponge, and gives it out gradually to the streams below. These patches of evergreen regetation act as regulators of the water-supply, and explain why, in a tract of country having a poor rainfall, scanty evergreen regetation and no marked hill features, such a large number of important streams are to be met with, some of which, at all events, contain pools of water even at the driest season of the year.

In the vicinity of the small hunting village of Jwafuabutan two remarkable, isolated rocky hills are to be seen. 'They are flattopped, and have almost perpendicular sides of rock, imbedded in which are horizontal layers of pebbles and conglomerate. They remind one of the rocky escarpment sometimes found on the " higher valley gravels" of large streams. It may be that these two hills are the remmants of escarpments that once formed the old banks of the Volta River, when it was carving out these plains.

The rocks forming the hills are very much riven and split asunder; in the chasms thus formed rich soil has accumulated and now supports luxuriant evergreen vegetation. I found beautiful little ponds and streams on the rocky terraces near the summit of one of the hills, and also obtained from there a magnificent panoramic view of the hill system of $K$ wahon and Eastern Akyam.

Reverting now to the forest vegetation of these plains it consists for the greater part of deciduous-leaved trees, scattered ahout 
the grass that covers most of the plain, reminding one much of a densely planted orchard in Europe. The trees, however, generally attain a much greater height than one finds in an orchard, and in this respect the resemblance is closer to thickly timberer park land.

In depressions where the soil is rich and deep but not sufficiently moist, to support evergreen regetation, the deciduous-leafed trees attain good proportions; they grow closer together, have fine, clean, straight stems, and resemble in density of stock a mature oak wood at home, or the better class of dry deciduous forests of Central India and Central Burma.

The annual fires appear to do but little damage in these wellwooded areas, and the natural regeneration of the species inhabiting them is excellent and far more satisfactory than that usually met with in the dense evergreen forests of the regions having a heavier rainfall.

Where the soil is shallow, resting on outcrops of rock, or where other impermeable pans are situated close to the surface, the tree growth is poor, the plants are grnarled and much twisted, and suffer greatly from the annual fires that sweep over the country. Another variant occurs in localities where a substratum of stagnant water exists and the soil appears to be acid. Here vegetation, excepting the grasses, is very meagre, and we thus get the beautiful grassy glades so common in some parts of the open forest country.

A large proportion of the trees inhabiting the "dry zone," to which these plains belong, have developed a very thick corky laver of bark; this, no cloubt, serves to protect the stems against injury from fire and drought.

The most marked difference between this type of regetation and that inhabiting the moist regions, with a rainfall of 50 inches a year and over, is the extreme paucity in variety of species characteristic of the former. 'The comparatively few species, however, that do occur here are numerous in individuals, and they very often show a tendency tow ards the gregarious habit. Other differences are the dominance of the grasses and the satisfactory state of the natural regeneration in the open forests.

The species characteristic of this type of forest are amongst the trees:-

The balsam copaiba tree (Daniella thurifera), the Senegal rosewood (Pterocarpus erinaceus), the cutch tree (Acacia Catechu), Lcaciu Sieberiana, Acacia nigrescens, or a closely related species, the I'apoa (Afzelia africana), a fine timber tree, the "dry zone" cedar (I'seudocedrela Kotschyi), the "dry zone" mahogany (Khaya senegalensis), Ormosia laxiflora, Detarium senegalense, another good timber tree, the "sass wood" or ordeal tree (Erythrophloeum guineense), which furnishes a good timber; one of the so-called "African oaks" (Lophira alata), the seeds of which are rich in regetable oils, and the timber of which is extremely durable; it is a congener of the Kaliu. (Lophira procera), from the moist evergreen forests of the maritime zone; a species of Tcrminatia; a species of Datbergia; the Toruba " chew-stick" 
tree (Anogeissus leiocurpus), the wood ashes of which are used as a mordant for fixing dyes, and the roots as chew-sticks in the - Yoruba country; Vitex cuneata and Vitex megaphylla, the fruits of which are much sought after by elephants; Parinarium curatellafolinm, with edible fruit; l'arimarium mobola; the West I frican "locust bean" (Parkia filicoidea), the legumes of which are also edible; the shea butter tree (Butyrospermum l'ariii); the baobab (Adressonia digitata), the tamarind (Tamarindus indica), the Sierra Leone Tamarind (Jialium guineense), and Ficus platyphylla.

Small trees and shrubs are represented by Entada soudrnica: Entada abysinica; Crossopteryx Kotschyana; Bauhinia reticulata, the bast fibres from which are used for making ropes and the acid infusion of the leaves for coagulating kuntumia elastica latex; the wild custard apple (Anona senegalensis), the fruits of which are edible; the " dry zone" form of the Kishia (Sarcocephalus esculentus); Gardenia sp., probably G. ternifolia, with edible fruit; Engenia owariensis; Bridelia micrantha, that yields a red dye; Strychnos emarginata; Carissa edulis; a species of lizyphus; and Cochlospermum tinctorium.

Amongst herbs we have Cassia mimosoides, and various species of Indigofera, Tephrosia, Desmodium, Oldenlandia, Capparis, sc.

'The orchids are represented by two species of Lissochilus, one of which, $L$. rosens, has very beautiful flowers.

Gloriosa superba and another pretty species of the same genus, G. virescens, and Asparagus africana, are the most conspicuous representatives of the Liliacea, whilst the Amaryllidece contribute various species of Crinum and Hemanthus to the florat.

Amongst the palms we have the fan pahm, Borassus flabelliformis var. athiopica, which is extremely abundant in the vicinity of the Bunda River. The pericarp is edible and the timber very durable. A wild date palm, Phonix reclinata, and a few dwarfed oil-palms and Raphias, which are usually confined to the neighbourhood of streams, complete the list.

'The belts and patches of evergreen forest clothing the richer' and moister soils are composed of various species of trees, such as Sterculia cordifolia, S. Barteri, P'terocarpus esculentus, Mimusops multimervis (a good timber tree), Cynometra Mannii, Berlinia acuminata (another timber tree), Ricinodendron africamns (seeds rich in vegetable oils), Alstonia congensis (soft wood, used for manufacturing native stools), the ebony tree, Diospyros mespitiformis, several species of Ficus, Carapa guianensis (seeds rich in regetable oils), the silk-cotton tree, Eriodendron anfractuosum, and the camwood (Baphia nitida). The majority of the species enumerated above are also common to the forest belt of the Gold Coast. Two species, however, the sasswood tree (Erythrophloum guincense), and the chew-stick tree (Anogeissus leiocarpus), which are typical of the dry open forests, often invade these isolated patches of evergreen regetation.

Rubber-yielding plants are here represented by Landolphia owariensis, L. Thompsonii, and Carpodinus hirsuta, only the first-named species of which furnishes rubber of the first quality. 
Grouping together the useful plants found in these dry open forests and the narrow belts and small patches of evergreen regetation scattered about them we have:-

\section{A. Timber Trees.}

1. Afzelia africana, Opapao of the Aquapims, generally distributed over the open country. Where not exposed to much damage from fire it attains fine dimensions, and becomes more or less gregarious. The natural regeneration by seed is excellent. and probably better than that of any other species of timber tree to be found in this part of the country. The various age gradations are also well represented. The timber is hard, durable, and of first-class quality; it has been frequently exported to Europe from the Niger under the general trade name of "African Nahogany," and is largely used on the Niger for making furniture. It is also far and away the best shade tree of the open country. Altogether this species appears to me to have a great future before it, not so much perhaps for purposes of export as for local requirements in the arid regions of the hinterland. From a professional point of view it has the great merit of repro. ducing itself freely by seed and being a rery hardy species. It will probably respond readily to technical management, especially if it is protected from the annual fires in the more arid districts.

2. The Balsam Copaiba Tree, Daniella thurifera.-This species is also very abundant in the dry zone. It reaches fairly large dimensions, reproduces itself freely by seed, and has the age gradations well represented. The wood is durable and is impregnated with a wood-oil (resin) that was exported formerly from the Niger under the name of "Balsam Copaiba." It is, in fact, quite a useful timber tree for local requirements. Like Aficlia africana, it will also probably be easily amenable to systematic management.

3. Detarium senegalense.-Not so universally distributed as the two former species, but extremely abundant in certain localities, especially where the subsoil is rocky. Natural regeneration by seed is good, seedlings are plentiful, and the age gradations satisfactory. 'The timber is said to be of excellent quality, but there is some doubt as to its durability when freely exposed to atmosvheric influences. Does not attain very large dimensions.

4. The dry zone Mahogany (Khaya senegalensis). This is a small species of West African mahogany that is confined to the open country. It sometimes attains a girth of 6 feet, but the usual size is from 4 to 5 feet. The timber appears to be similar to that of the other West African mahoganies. In the driest parts of the open country it is confined to the vicinity of the streams. The growth of this species could no doubt be considerably improved by protecting it against forest fires. Natural regeneration by seed is fairly good.

5. The dry zone Cedar (Pseudocedrela Kotschyi).-Extremely common in some parts of the dry zone; local in its distribution. In favourable localities it attaius a fairly large size and yields a very beautiful wood. Seedlings are numerous wherever it 
occur's, and the age gradations are good. This species should have a great future before it.

6. Erythrophloum guineense, the Potrodom of the Ashantis and Akwapims (the sass wood or ordeal tree).-Local in its distribution, but very abundant wherever it does occur. Attains a large size. Wood hard and fairly durable. Used for building purposes on the Niger. Bark poisonous, infusions of it are used by some of the natives (especially on the Kroo coast) for the ordeal test. Regenerates itself freely by seed. Young plants numerous and age gradations satisfactory. This species often invades the belts of evergreen forest to be met with in the dry country.

7. Lophira alata (one of the so-called African oaks).-The commonest tree of the open grass country. Universally distributed there, is closely related to the Kaku tree (Lophira procera) from the evergreen forests of the maritime zone, the wood of which is the most durable to be found in tropical West Africa. On good soil it attains a large size, but is usually of a crooked and stunted growth from injuries caused by the annual fires. Seeds small, but very rich in vegetable oils. Natural regeneration very good. Age gradations well represented.

The following species are confined to the evergreen belts of forest found in the open grass country:-

8. Mimusops multinervis.-Confined to the vicinity of the streams. Wood hard, reddish in colour and very beautiful, often figured: exported from the Niger as African mahogany; attains large dimensions. Not rery common on the Afram Plains. Natural regeneration by seed rather poor.

9. The ebony tree, Diospyros mespiliformis._- Not common. Attains a large size. Heart wood black and furnishes one of the ebonies of commerce. Also found in the mixed evergreen and deciduous forests of the intermediate zone (between the moist evergreen belt and the dry zone). Age gradations poorly represented.

10. Berlinia acuminota or a closely related species. Extremely common along the banks of streams on the Afram Plains. Wood hard and fairly durable. Usually of crooked growth.

11. The Camwood tree, the Odwen of the Akwapims, Baphia nitida. Very plentiful in some of the evergreen belts of vegetation. Scarcely attains the dimensions of a small tree.

12. The Senegal rosewood tree, Pterocarpus erinaceus. Confined to the open forests. Local in its distribution. Never attains a large size in this country. Natural regeneration good.

13. Carapa guianensis. The Osuabise of the Akwapims. Confined to the evergreen belts near the banks of streams in the open country. Attains greater dimensions here than I hare seen anywhere else. Also found in the moist evergreen zone of regetation further south. Wood has a great reputation in the Senegal. Seeds are rich in regetable oils.

14. Tamarindus indica. The tamarind tree. Local in its distribution. Found in the open forest just outside the evergreen 
belts in the vicinity of the larger rivers. Furnishes an ornamental wood. Fruit edible. Grows to a fair-sized tree.

15. The fan palm, the Kube of the Akwapims, the Ma Kube of the Ashantis, Borassus Alabelliformis var. whiopica. Universally distributed and extremely common in places, as, for instance, in the vicinity of the small hunting village of Bunda Su, and in the valley of the Sumin River. Very characteristic of the open country and one of the most useful trees found there. The wood is praetically imperishable, the straight stems are very suitable for house posts, bridge piles, \&c. The pericarp of the nut is edible and the leaves are used as thatch.

Of the species enumerated above the most suitable for export are Nos. 1, 4, 5, S, and 10, if of large size. Under proper management and with the help of fire protection the growth of these trees could no doubt be considerably improved.

\section{B. Trees the Fruit and Seeds of which are rich in Vegetable Oils.}

The most important of these is the

(a) Shea butter tree, the $N^{\prime} k u$ of the Ashantis, Akwapims, and Fantis, Butyrospermum Parkii. A small tree, very characteristic of the open forests, and extremely plentiful in places. Is frequently confounded with Lophira alata which it somewhat resembles and which inhabits the same region. This speeies (the shea butter tree) is very prolific and quantities of the fruit can be seen lying about rotting under the trees. The tree is common in the vicinity of the Volta, Afram, and other navigable river's, and as the oil is of great commercial value, efforts should be made to develop an industry in it on a large scale. Extensive tracts of country in British West Africa are inhabited by this species and the exploitation of the product on a large scale would considerably increase the value of what are at present looked nuon as waste lands. I was glad to notice that the inhabitants of the small village of Sadang at the foot of the Kwahu Hills, on the Abetifi-Atabobo road, were collecting the nuts for export down the Volta River.

Other species rich in oils are:-

(b) The so-called A frican oak, Lophira uluta, the seeds of which contain a high percentage of oil; they are, howerer, very small, and it is doubtful whether the collection of the seeds on a large scale would prove remunerative. As mentioned above, the species is universally distributed in the open grass country. Its congener, I. procera, the Kaku, from the maritime zone, has much larger seeds, and it may pay to collect them.

(c) Ricinodendron africanus. The seeds of this species have been analysed in Europe and found to eontain a very high percentage of useful regetable fats. The tree is most prolific and large quantities of seed are available if a demand springs up for them. This tree is quite common in the mixed evergreen and deciduous forests of the intermediate zone. In the open country it is confined to the belts of evergreen forest. 
(d) Carapa yuianensis. 'The Osuabise of the Akwapims. This is another species with large seeds that contain a high percentage of vegetable fats. In the dry country it is confined to the banks of the streams, but is universally distributed over the heavy forest belt. The seeds if required could be procured in fairly large quantities.

Amongst other useful trees we have:-

(c) Acacia Catechu. 'The species from which the Cutechn exported from Burma is procured. It is common in the open grass country, and in places is so gregarious as to form almost pure thickets. The heart-wood from which the Catechu is extracted in Burma is, however, poorly developed in the West African plant.

The fure yielding plants, not including the various species of Urena, Triumfetta, Hibiscus, and a small Sansevieria which are almost universally distributed, are represented by-

(f) Sterculia Barteri. A tree that is confined to the evergreen belts of vegetation in the open country and is most plentiful in the intermediate zone. The bast fibres of this species are used by the natives for making ropes, which are strong and lurable.

(g) Bauhinia reticulata, the bast fibres of which are put to the same use. It is universally distributed over the dry zone and is frequently the only plant available in such localities from which really long and strong fibres can be procured.

(h) The Baobabs, Adansonia digitata and another species. 'These gouty-looking trees are found here and there in the open country, more especially near villages and on rocky soils. I very much doubt whether they are truly indigenous on the Gold Coast and in Southern Nigeria.

The wood fibres of these trees are collected in Senegal and exported to Europe where they realize from $£ 9$ to $£ 10$ per ton. I should fancy that in favourable localities the growth of these plants is fairly rapid and that with planting a large supply of fibre could be obtained and collected at no great cost. It would, of course, only pay to grow it as a forest crop.

'The roots of (i) Anogeissus leiocarpus, a tree that is extremely common in the dry zone, are rich in tamnin and the wood ashes are used by the Yorubas as a mordant for fixing dyes.

Infusions of the bark of (j) Bridelia micrantha or a closely allied species are used by the native hunters to dye their cloths a rich reddish-brown colour; the dye is said to be a fast one, and the admixture of scraps of old iron (such as kerosene tins, \&c.), with the infusion of the bark appears to be an important part of the process in fixing the dye.

'The following species of plants from the open country possess edible fruit :-

(a) Parinarium curatellafolium. Locally conmon.

(b) Parkia filicoidea. Common.

(c) The shea butter tree. Common, the pericarp is edible. It has an agreeable sweetish taste. 'The "butter", is, of course, used for culinary purposes. 
(d) Adansonia digitata. The fibrous pulp is eaten by the natives. It has an acid flavour. The seeds also are washed, pounded up, and then steeped in water for ten days and the infusion so obtained used by the natives of North-Western Ashanti for flavouring their soups.

(e) Tamarindus indiea. The tamarind. Local in its distribution. Found near the larger rivers such as the Volta and the Afram.

(f) The Sierra Leone tamarind, Diulium guineense. Very local.

(g) Fieus platyphylla.

(h) Anona senegalensis. The wild custard apple. Very common.

(i) Sareocephalus esculentus. Very common.

(j) Gardenia sp., probably G. ternifolia. Common.

(k) The pericarp of the nut of the fan palm, Borassus flabelliformis. Very common.

Wood oil is furnished by the "Balsam Copaiba" tree, Daniella thurifera, which is very abundant in the open country, and Gums by Acacia Sieberiana, the dry zone mahogany (Khaya senegalensis), and the chew-stick tree, Anogeissus leiocarpus. 'These gums, howerer', appear to be of inferior quality.

It is the custom to look upon the forest regretation of the open country as being practically worthless, but the list of useful plants given above will, I hope, help to dispel this idea. No doubt the dense evergreen forests of the moist belt are more imposing and appeal more to the imagination than do the parklike forests of the hinterland, but they are far more difficult to deal with professionally. 'The proportion of useful species to the rest is small, the natural regeneration is generally poor, and the age gradations are invariably in a very unsatisfactory condition; whereas the converse with lespect to all these points holds grood in the case of the open, deciduous forests just described. Here the only dithculty to contend with is that of fire protection, the cost of which, however, is likely to be heary.

Of course, where the preservation of the water-supply or other climatic factors are of importance to tropical agriculture, such as the cultivation of cocoa, cola, rubber, and other useful plants demanding a hot moist climate or otherwise, it is imperative that suitable forest areas should be strictly conserved with a view to maintaining the water-supply and preventing the spread into the forest region of the grass country. This, together with the creation of forest reserves for the constant supply of timber and other forest produce derived from species that are confined to the moist belt, necessarily shifts the centre of gravity of roresc management to the heavy forest region, but this is no reason why the park-like forests of the open country should be neglected; they will respond far more readily to professional treatment than the dense evergreen forest and will be much more easy to exploit with modern mechanical appliances. At the same time their fireservation will steadily improve the quality of the soil and 
keep it in the best possible condition for agriculture should the occasion ever arise to give the land over for that purpose.

In this connection I may remark that some of the most valuable forests of India and Burma belong to similar open, deciduous types.

'The type exists over an extensive tract of country in the hinterland and, as such, the richest portions are well deserving of protection and systematic management. In the vicinity of Kintampo and N'koranza there are some very fine examples of these forests that are well stocked with the most valuable species of timber trees to be found in the country. They are, I am sorry to say, being rapidly destrosed, near Kintampo especially, for farming purposes.

Other localities where good forests of this kind exist are along the foot of the range of hills to the west of the villages of Braha and Oboase in North-Western Ashanti, and between Bian auu Jugbe in the Northern Territories.

I very much regret that for want or time I was unable to make an extended trip to the Northern Territories, where the climate is such as to make forest conservancy a matter of the greatest importance. The small tract of country visited by me on my way to the main Bola-Kintampo road enabled me to form some idea of the forest regetation found just north of Ashanti. What I saw of it was encouraging, but 1 believe that the regetation further north, beyond the ninth parallel, is rather meagre.

The localities visited on the Afram Plains lay in the direction of the Abetifi-Atabobo road as far north as Suminsu and Bundasu on the Sumin and Bunda Rivers. The forests lying to the right and left of the path were in sereral places examined for somr. miles on either side and a short excursion was made in a hithert: unexplored tract of country situated to the north-east of Bundasu in the direction of Krachi. The descent of the Kwahu hills from Abetifi to the plain is much less abrupt than it is either to the west or south of that town. In fact, the road taken by us has the best gradient of any leading on to the plateau. The slopes of the hills are covered with farms of koko rams, cocoa, bananas, and corn; belts of forest, however, have been left intact here and there and they contain numbers of a species of mahogany with large leaves, probably Khaya grandis. Ther attain a large size, and roung plants of lifferent ages are fairly plentiful, but they are of crooked growth. The regetation in general is evergreen and similar in character to that met with between $\mathrm{Obo}$ and Abetifi with one important exception; on the middle slopes of the hills occurs a wide belt, which has not heen destroyed for farming purposes, of a "pure forest" (i.e., a forest consisting practically of only one species) of an evergreen tree that is either a species rif Cynometra or a Brachystegia; with the exception of the mangrove forests on the coast, this is the most extensive example that $I$ have met of a type of forest that is extremely rare in tropical West Africa, but which, on the other hand, is the dominant type in Northern Europe and Asia. The leaf canopy of this forest was complete, and practically the only plants 
found growing in the dense shade underneatl were young individuals of the same species as the over-wood. The soil on which the forest is growing is very rocky.

Close to the village of Sadang, at the foot of the hills, there is a fairly large feerler of the Afram River that may be utilised in exporting down to the Volta, and so on to the sea, the mahogany growing on the northern slopes of the Kwahu hills.

Between this village and $K$ wantanan the forests have been much destroyed for farming purposes, but what is left belongs to the type found in the intermediate zone. Neither of us, homever, was prepared for the extraordinarily abrupt transition from this type to the dry, open forests of the plains that occurs at that village. We practically stepped out from the village (in a northeasterly direction) into the latter type of forest.

In the vicinity of Aframsu there is an extensive patch of evergreen forest which follows the Afram River for a long distance. The country is very well watered about here, and several large feeders of that river are crossed within the space of a few miles; heavy rain had just fallen and they were all in flood. The plain itself was also under water.

Shortly after leaving Aframsu we got into good open forest with trees of excellent growth for that type of regetation. Four belts of evergreen forest were crossed and we then passed between the two isolated rock hills that stand out of the plain close to the small hunters' village of Jwafuabutan. These two hills are surrounded with forest of good growth. Fine specimens of Afzelia africana, Detarium senegalense, and the dry zone mahogany (Khaya senegalensis) are found here. Some three hours' journey to the north-west of the village the land gradually rises up to a rocky ridge, the lower slopes of which are clothed with excellent forest. Large sheets of rock begin to appear and the village itself is situated on an outcrop of this sort from a pool, from which the inhabitants procure their water. There is an extensive patch of evergreen forest to the north of the village, and a smaller one between it and the more easterly situated hill of the two mentioned above. Further northwards a broad belt of evergreen vegetation follows the course of the Obusumbone River, which is of quite a respectable size. The rest of the vegetation is of the dry zone type. Open grassy glades containing little tree growth are frequently met with and increase in numbers as one approaches Suminsu, where another broad belt of evergreen forest is found along both banks of the Sumin River. As a general rule, about this portion of the undulating plains the higher land is clothed with good open forest and the depressions with grassy glades, except where the more important streams have carved out their channels; these are invariably fringed with evergreen forest. Terraces of rock become more plentiful about here and continue to increase in numbers towards the north-east in the direction of British Krachi. Between Suminsu and Bundasu the fan palm becomes the dominant species and cover's an extensive tract of country, more particularly towarls the north-west between the Bunda and Sene rivers. Shea butter trees are plentiful all over this part of the 
country and the species is quite common in the ricinity of the Afram, which is a navigable river. The collection and trangnort to the Volta River of the nuts should, therefore, present vo difficulty. The country is, of course, rery sparsely populateci, and any labour employed for this purpose would have to be procured elsewhere.

Early in the year, when the young grass has just sprung up, after the annual fires have swept over the country, these plains are said to literally teem with game of every sort. With the exception of two herds of buffalo, one hartebeest, one elephant, a few duikers and kob and wart hogs, we saw but little at the time of our risit. The grass had grown high, water was plentiful everywhere, and the game had dispersed in all directions instead of being concentrated in the vicinity of the few pools that contain water in the dry season. Judging from the game tracks met with, elephants and buffalo must be very plentiful. Large numbers of them are slaughtered every year and the flesh taken $u_{i}$ to Abetifi for sale. We met numbers of people almost every day who were employed in carrying the smoked flesh to that town. The slaughter of elephants must be great, as one of our guides told me that he had shot ten in one month. Several had been killed just before we arrived at Abetifi. Elephant meat can be purchased almost any day at Abetifi.

Some steps should, I think, be taken to limit the number of liunters who shoot on the plains. The small villages scattered about them are inhabited solely by professional hunters, outlaws, and the riff-raff of the country, who earn their living by shooting game and selling the flesh in the larger towns. The quantity consumed for their own use is insignificant compared with what they sell.

Abetifi is the great centre to which the bulk of the smoked flesh is brought. It is the worst offender in this respect. Some of the more well-to-do inhabitants own small hunters' villages down on the plain, and a portion of everything shot in the ricinity has to be sent up to them for disposal.

Whilst Europeans are obliged to take out licences and are (rery properly) restricted as regards the shooting of certain species, no steps whatever have been taken to in any way limit the incessant slaughter carried on by the natives. W' hat the few Europeans out here who care for big game shooting kill is a inere drop in the ocean compared with the annual bag of the native hunters, ret the only restrictions existing are placed on the former. Surely, if the reason for enforcing game licences at all in the case of Europeans is the preservation of the game in the country, some action might be taken to restrict the immense amount of damage done by the natives. As matters stand, game preservation out here is an utter failure. The real offenders have not been touched by the legislation regulating this matter. The killing of cow elephants and their young by the natives has not eren been prohibiter, and, in fact, the game laws contain a clause that specifically exempts the natives from their application. The argument is often put forward that the slaughter of wild animals has been going on for generations and 
that they are still as plentiful as ever. This statement, however, does not agree with the facts. The native hunters themselves admit that game is getting scarcer and scarcer every year, and that they have to go further afield to get it. In the olden days, when internecine warfare was practically the normal state of affairs, the hunters, who formed the bulk of the armies engaged, had but little time to devote to the chase of wild animals; now, with peace assured, they have taken to it with renewed energy and are quickly making their mark felt.

I may remark that a large proportion of the trophies taken out of the country every year by Europeans has been either purchased from the native hunters or picked out from the hunters' "heaps" of skulls found in some of the villages. Very few of them consist of bona fide trophies obtained from animals shot by the Europeans themselves. I only mention this fact in order to remove the erroneous impression that the Europeans are responsible for the annual slaughter of a large number of animals. Proper enquiries will, I think, confirm my assertion. Only those who have had real experience of big game shooting in tropical West Africa can realize the arduous nature of the undertaking involved in procuring anything like a large bag. Again, the number of Europeans out here who would walk a mile in full exposure to the sun to shoot a wild animal is extremely small. To sum up, it may be safely accepted that, with perhaps the exception of the hippopotamus, there is at present no danger of the large game of tropical West Africa being exterminated by the white man. The conditions out here are far too unfavourable for any but the greatest enthusiasts to take up in earnest big game shooting as a pastime. The real danger comes from the native inhabitants themselves.

An alternative to limiting the number of native hunters allowed to shoot on the plains would be to take up a portion of the latter as a game reserve and to strictly prohibit all shooting within the area selected.

During our return to $A$ betifi we found that the greater number of the swamps met with before had dried up and the walking was, iu consequence, done in more comfort. From Abetifi we proceeded to Aburi viâ the Impriso-Kankan-Bunsu-Ku KurantumiKoforidua road.

\section{JouRNeY From ABetifi to Aburi.}

The small plateau on which Abetifi is situated is connected hy a series of step-like descents with the much more extensive and flatter plateau of Impriso. This appears to be an ideal place for the residence of Europeans and is only some 300 feet lower than Abetifi itself. There is any amount of flat ground a railable for building sites and recreation grounds, water is plentiful, the climate is bracing, and the place is not so exposed to strong winds. About two hours after leaving Impriso one comes to the steep escarpment that abruptly terminates the plateau to the south. The path down the face of the escarpment is rery rough and in places, where there are huge overhanging ledges of rock, has to be negotiated with some care. 
After a descent of something like 800 or 900 feet the broken country comprising the basins of the Imoi and Birrim rivers is reached. Generally speaking it is well wooded and contains the remains of what must once have been very fine forests rich both in cedars and mahoganies, and comparable in many respects with the best forests of Tpper Sefwi and Western Ashanti. Now, however, they have been extensively cut up by farms in which cocoa is the dominant crop. All things considered, it is perhaps just as well to sacrifice these forests in the interests of agriculture as the locality is eminently suited to the cultivation of cocoa, kola, rubber-yielding plants, \&c., that require a humid atmosphere for their best development. But in doing so it should not bc overlooked that there is a limit to the amount of forest that can be destroyed with impunity for that purpose. Their complete extermination would entail the eventual failure of the very crops that it is proposed to cultivate on a large scale. In a tropical country like this it is imperative that the woods clothing the crests of the hills and the higher slopes, especially near the sources of the more important streams, should be strictly ronserved, and on no account whatever should the slopes of the hills facing the dry open forest country be denuded of vegetation-that is, if it is intended to devote the districts of $\bar{K}$ wahw and Eastern Akyem to the cultivation of crops of the nature indicated ahove. In any case, whether such crops fail or not in the end, the destruction of the forests clothing the hills will adversely affect the water-supply of the country to such an extent as may hring disaster to localities remote from the area in which the damage was originally done. No agricultural crops, however densely they are planted, can ever replace, as regulators of the water-supply, the forests now clothing the hills.

I am sorry to say that a great deal of damage has already been done to these forests, as, for example, along the slopes of the Abetifi Hills facing the Afram Plain, the slopes of the Aburi Hill system faciog the Pram Pram and Accra plains, and, so I am informed, of the slopes of the hills adjacent to the Krobo Plains.

Grass, that harbinger in tropical West Africa of the doom of the evergreen forests (on which the water-supply of the country is so dependent), has established itself on several of these hills, even on some of the higher peaks of the $\mathrm{K}$ wahu system, as, for instance, near the important town of Obo, and it will only be a matter of years, if the forests continue to be destroyed, for it to take such possession of the soil as to practically exclude all evergreen vegetation. With the grass comc the annual fires of the dry season and the damage thus becomes accentuated from year to year, till a complete change in the regetation and climate becomes established. The different stages in this change can be easily observed along the Aburi-Accra road, wherc excellent examples exist of the transformations resulting from the reckless destruction of the forests.

It is hard to conceive any more difficult or serious problem, affecting the general welfare of the country, than that which now confronts the Administration in comnection with the preservation 
of the evergreen forests on which the water-supply of the Colony and Ashanti depends. If it is immaterial whether the whole of the evergreen forest region becomes eventually converted into the open type of forest characteristic of the so-called "dry zone" or not, then the problem need not be attacked; but in this eventuality the country must be prepared to face the diminished water-supply, the drying up of what are at present important perennial streams, and the limitations as to the variety of agricultural crops that such a climate can support.

If, on the other hand, it is decided to preserve the water-supply and the moist climate on which such a large number of agricultural crops depend, and there is no question as to which is the wiser choice, then immediate action is necessary. Already such damage has been done as will take years and the expenditure of large sums of money to repair, and there is no time to lose.

The problem should be attacked on scientific lines and such steps taken as will ensure the protection of the forests concerned. On the one hand there is the agricultural system of the natives, which is one of the most wasteful known and which entails larger areas being taken up for crops than any other method lemands, to contend against: on the other side the possible inclusion, on the advice of over-zealous advocates of reservation, of larger tracts of forests within the reserved area than is actually necessary to meet the wants of the situation. A just balance should be drawn between the conflicting interests.

In this connection I may remark that the accumulated effect of timber exploitation on the climate of the country is a mere bagatelle compared with that resulting from the wholesale destruction of the forest for farming purposes. If every mahogany and cedar tree in these forests were exterminated, it would have but little influence one way or another on the rainfall, because the forest vegetation as a whole would practically remain intact, whereas the clearings for farms remove at one fell swoop every stick of the regetation clothing the areas selected for cultivation.

The preservation of the water-supply and the climatic factors of the country must always claim first attention in any rational scheme of forest administration, and compared with it the regulation and control of timber exploitation is of secondary importance, unless indeed the exploitation is so extensive as to threaten the existence of the forests themselves, a contingency not likely to arise out here, where only comparatively few of the species composing the forest regetation are of any economic ralue.

Indeed, the extraction of major forest produce (timber) on the Gold Coast wants regulating not so much on account of any danger threatening the forest vegetation as a whole, but with a riew to ensuring a continuous and sustained yield of the produce.

I strongly adrise that a commission, composed of a trained agriculturist, a trained forester (both of whom should have experience of the trojics), and a Travelling Commissioner, be deputed to risit the districts of $K$ wahu, Eastern and Western Alirem, and Aburi, where farming is heing sarried out on a large 
scale, and to decide, in consultation with the native chiefs and communities concerned, what forest areas are to be protected from the axe of the farmer.

There is certain to be great opposition on the part of the natives to the formation of the reserves, and it will probably be very difficult to convince them that the proposed measures are being introduced for their own interests and that of the country at large.

Nerertheless, a determined effort should be made to ensure the protection of at least the forests situated at the sources of the more important streams, and for this purpose it will not suffice to select small patches of vegetation here and there; nothing but continuous belts of forest will serre the purpose. If, in addition, it can be arranged to leave intact strips of forest vegetation between the different farming centres to act as barriers to the spread of plant diseases, so much the better.

On no account should a scratch commission composed of mombers possessing no special qualifications for the work in hand be selected, otherwise irreparable damage may result from their labours.

The best forests seen on the main Abetifi-Aburi road are situated between the rillages of $\Lambda$ betinso and Kankan, and between the former place and the southerrn escarpment of the Abetifi Hill svstem. They are rich in all the raluable timberyielding species of this coast, with the exception of the $N$ yankon and Kaku, species which are restricted in their distribution to the maritime zone.

From the village of Kankan onwards towards Aburi cocoa and other farms are rery plentiful, more particularly between Kukurantium and Koforidua and between the latter place and Aburi, where, with the exception of the "standards" left as shade trees, practically the whole of the tree growth has been destroyed. This part of the country already shows signs of becoming drier, and plants characteristic of the mixed deciduous and evergreen forests bordering the dry zone have made their appearance.

The forests situated in the upper basin of the Densu River have been much destroyed for farming purposes, but those protecting the sources of its main feeders on the Kyebi range of hills and the south-eastern extension of the Begora Range have so far heen left intact. As long as these forests are preserved there is little risk of the water-supply of the stream being seriously diminished.

When at Bunsu the opportunity was taken to risit $\mathrm{Mr}$. Pritchard's plantation. It consists of 2,500 acres, of which 170 acres have been mainly planted up with Para rubber and 140 acres with kola.

The plantation has been divided up into blocks by a well laid out system of roads, and the Birrim River flows through the centre of it. The Para rubber trees appear to be doing fairly well, but the great interest centres round the kola plantation. The growth of this species in its early years is rery slow compared with that of other crops, but when it does come into bearing 
there is no doubt that it is one of the most paying crops in the country. The best market for this produce is in Northern Nigeria, and it is quite unaffected by any fluctuations in the demand for kola in Europe. Like the majority of the indigenous West African plants, the growth of the seedlings is considerably checked by transplanting, hence it is preferable to sow the seeds out to stake. This is being done with success in the Bunsu plantation, where all the young plants so raised are showing excellent growth. Mr. Pritchard deserves every credit for the enterprise shown by him in striking out what is practically a riew line of his own. The kola plantation should prove a paying concern in a few years' time.

As regards the agricultural prospects of Eastern Ashanti and the Kwahu, Akyem, and Aburi districts of the Colony, I think that, providing the climatic factors remain unchanged, there is \& great future before them, and that any expenditure likely to be incurred in constructing a railway to tap these centres and in open up the bracing highlands of Kwahu as a residence for Europeans is quite justifiable.

To sum up. My tours through the country have conrinced me that the Gold Coast Colony and the Protectorate of Ashanti, more especially the latter, possess in their magnificent forests a great natural source of wealth the value of which, with proper management, should increase from year to year as the world's supply of timber becomes depleted and we have to fall back on our Colonies and Protectorates to make up part of the deficiency. Nothing is more certain than the fact that of late vears not only the wood increment but also a large portion of the wood-producing capital has been removed from the chief timber-producing centres of the world in meeting the vearly demand, and that the available supply is rapidly becoming exhausted. As some of the sources, such as the forests of Canada, the United States, and Asiatic Russia, for instance, are brought under systematic management, the output from them will have to be considerably curtailed, and this will further reduce the available supply. $\dot{A}$ beginning has already been made in these countries by the forest management in each being placed under the charge of a properly constituted forest department, and no doubt the result of their efforts to prevent the exhaustion of the wood-producing capital will soon be felt in the timber markets.

\section{PART II.}

\section{A. Protection of Forests and Forest Legislation.}

(a) Dangers to which the Forests are exposed:

On the Gold Coast and in tropical West Africa generally the dangers threatening the existence of the forests are:-

(a.) The wasteful system of farming practised hy the natives. 
(b.) The over-exploitation of the forests for timber, fuel, and other produce, such as gums, resins, rubber, $\mathcal{E}$.

(a.) Uf these the former is by far the greater and must, if allowed to continue unrestricted for a sufficient length of time, result in the virtual extermination of the forests. The latter is not so serious, unless a rery large demand for fuel arises and the fellings are permitted to be undertaken without restrictions as to their extent and character. The ordinary exploitation for timber and minor forest produce can never, even if pushed to the rerge of extinction of the particular species of plants concerned, have the same effect on the forests as a whole, as the damige resulting from the unrestricted destruction of them for farming purposes, because in the former case only a few species in comparison with the huge number forming the balance of the growing stock of the forests are of sufficient economic importance (at the present time at all events) to be threatened with orer-exploitation, whereas in the latter case practically the whole growing stock is removed at one fell swoop whenever the forests are cut down for farms. So far then, from the point of view of looking at the forests as a whole, more especially in connection with their rôle of preserving and regulating the water supply, of preventing the erosion of hill-sides, of acting as barriers against desiccating winds and the spread of arid conditions, and in connection with other protective functions, the over-exploitation of a comparatively few species is but of secondary importance. Hence it may be conceded that in any rational system of forest protection the steps necessary for ensuring the safety of a sufficiently large extent of forest to carry out these functions must receive first consideration whatever may be the demand for forest produce. This principle is so important that every European State without exception which has included forestry amongst its administrative measures has reserved to itself the right to interfere, by legislation, for the protection of those forests that, by their situation or otherwise, are best suited as "protection" belts to carry out this important rôle of forest regetation. The right to interfere is constantly being exercised over all sneh areas even when the property does not belong to the State, but to private individuals, corporations, communes, \&ic.

Sereral European countries, including all those in which forestry is most advanced, have in addition extended the exercise of this right to regulate, within certain limits, the methods under which non-State forests (private and communal forests) are crploited for the supply of forest produce, even when these forests are not required as protection against climatic agencies.

(b.) The second danger to guard against is that of over-exploitation of those wooded areas that are or should be set aside for the purpose of supplying a sustained yield of forest produce. It is this aspect of forestry, together with the quite subsidiary one of protecting the woods as sanctuaries for game, that is more popularly associated with forest protection and was the first to be developed in historical seguence.

This use of the forests, though not of such vital inportance to the welfare of a country as the protective functions mentioned 
above, is still sufficiently so to have resulted in an elaborate and special system of legislation being adopted for their protection and management by those states that have included forestry amongst their administrative measures.

Before proceeding to discuss the steps that should be taken on the Gold Coast, and indeed generally in our West African Colonies, to ensure the protection of forest areas sufficiently large to serve these two purposes for which forests are reguired, it will be advisable first to go into greater detail as to the resulis that are likely to follow, and in some cases have followed, the wholesale and reckless destruction of forest regetation, both in the temperate zones and in the tropics.

\section{(b) Dungers attending and following the reckless destruction of forests:}

The presence of forests is most inportant in view of the effects which they have both on the climatic and other factors of a country; among these may be mentioned:-

1. They mitigate extremes of temperature and render the climate more equable.

2. They exert a marked effect in regulating the water supply, more especially by ensuring the sustained feeding of springs and thus rendering the flow of water in riveis more continuous, and in tending to reduce the danger of violent Hoods.

3. They increase the relative humidity of the air, and in consequence reduce the amount of evaporation. This effect is strongly marked on hills in the tropies.

4. By the mechanical action of their roots and stems the plants composing forest vegetation assist in preventing landslips, erosion of hill-sides, the silting up of rivers, and arrest the progress of shifting sands.

5. They tend to increase the precipitation of moisture.

6. They act as wind-breaks, and protect adjoining cultivated areas against the action of cold or dry winds.

$\tau$. They act as barriers against the spread of fungoid and insect attacks from one cultivated centre to another.

Almost all these effects are more pronounced in the tropies, especially in localities with well-marked wet and dry seasons, than they are in the temperate zone.

As regards 1,2 , and 3 , their action is of the utmost importance in preserving the water supply during the intense heat of a tropical dry season, and it is in this comnection that the wholesale destruction of the forests by the native farmers is attended by the greatest dangers. In the maritime zones of tropical West Africa, where the monsoon currents are very pronounced, and a certain amount of precipitation occurs even in what are considered the dry months of the year, and where the air is constantly very humid, such destruction may be carried out with 
more or less impunity, as the soil is quickly re-clothed with luxuriant regetation, and the chief danger to be guarded against is that of erosion of the hill-sides.

Such regions enjoy a heary annual rainfall of 80 inches and more, and the dry season is not only of short duration but is interrupted at pretty frequent intervals by showers of rain attending the tornadoes. The case is very different, however, in those portions of the hinterland, and also sometimes on the sea coast itself, where the rainfall is deficient or where a long and pronounced dry season follows the annual monsoons. It is difficult to state exactly what the minimum annual rainfall determining the "safety" margin of such a climate is, as so much depends on the distribution of the rain during the various months of the year; but so far my experience leads me to the conclusion that in a climate where the anmual rainfall is 60 inches and less the wholesale destruction of the forests is followed not so much by a marked deficiency in the rainfall, as by a general drying up of what were once perennial streams and a gradual transformation of the type of regetation clothing the locality.

This change in the vegetation will be realized if the influence of moisture in the soil and the degree of humidity of the air on plant life is recalled. Both these sources of moisture are affected very adversely (for plant growth) by the extensive destruction of forests, with the result that the original forests are gradually replaced by others of a drier type. The transformation is most rapid when extensive areas covered by drier regetation happen to be situated within a reasonable distance, say a dozen miles or so, of the locality in which the forests (of a moister type) are being destroyed, as there is always a marked tendency on the part of the former to encroach on the habitat of the latter. Once an area becomes clothed with drier regetation, then the conditions so far as moisture is concerned rapidly change for the worse. Forest fires make their appearance and all the effects on plant life become accentuated. Such alterations in the supply of moisture lead to the transformations of the moist evergreen tropical forests ("rain forests" of Schimper) to the mixed deciduous ones ("monsoon forests" of Schimper, in which a large proportion of the plants shed their leaves during the dry season and replace them at the commencement of the monsoons or wet period of the rear), and, if the reduction is continued, the conversion of the latter into the open savannalis so characteristic of the hinterlauds of our West Ifrican Colonies and also of certain areas along the sea coast where the mousoons are deficient. As a general rule the appearance of the grasses in any large numbers within a forest region otherwise occupied by evergreen vegetation is an almost certain index, in tropical West Ifrica, of the commencement of such changes. Erosion of the hill-sides and the tendency for violent floods to take place are also greater on land covered with the more open and drier types of vegetation. As examples of such transformations I may mention the tract of country between Accra and Aburi, where the rerophilous scrub gradually gives place to thorn forests and these to the savannahs at the foot of the Aburi hills and these in their turn 
to the mixed deciduous and evergreen forests on the hills. Wherever the original moist evergreen forests once covering the latter have been destroyed the secondary growth replacing it is assuming the mixed deciduous character. Lower down the hillsides and along the valleys at the foot, adjacent to the plains, clearings of the mixed deciduous forests have resulted in the encroachment of the open savannahs and their occupation of the cleared areas.

The great drawback to these conversions is, of course, from another point of view, the fact that the species occupying the different areas are replaced by other's more suited to the altered conditions, and this in time leads to the scarcity of those plants associated with the original environment. For instance, the majority of species of timber trees, and others of economic importance, that are confined in their distribution to the moist evergreen forests disappear from the scene under the altered conditions, and the same holds good with regard to agricultural and other crops such as cocoa, rubber plants, \&c., that are dependent for successful cultivation on moist conditions.

It is on these grounds that I strongly recommend that a protective belt of forest be left intact along the borders of the main cocoa-growing centres, especially those in Aquapim and $\mathrm{K}$ wahou where extensive dry areas are situated at no great distance from them. Examples of similar transformations are to be seen wherever extensive destruction of the forests has taken place along the borders of the various zones of forest regetation in Ashanti and Northern Kwahou, and are most apparent in the regions where the mixed deciduous forests approach the open savannah zone. The importance of leaving untouched sufficiently extensive belts of forest to regulate the water supply, more especially in the catchment basins of streams that may in the future be required for irrigation works, the water supply of distant towns, and for navigation, will be evident from the above remarks.

For all such protective purposes there is no doubt that the evergreen forests are the more desirable type. The mixed deciduous ones are to a large extent defoliated during the dry season, just when the supply of moisture in the soil requires the most protection against exposure to the fierce heat of the sun and desiccating winds. They are, however, better than having no protection at all.

In my opinion the influence forests have in mitigating extremes of climate in the tropics is their most important function. On the presence or absence of these extremes depend the existence of the rarious types of regetation. Howerer abundant the rainfall of a locality nua be during the monsoon period, if it is habitually followed by a prolonged dry season it can never in the tropics, except where telluric influences such as moisture in the soil near streams affect plant growth, be covered with the typical evergreen regetation. Once a prolonged dry season becomes an established condition of affairs edaphic influences depending on the physical and chemical properties of the soil assume an importance in relation to plant growth that is quite 
insignificant in regions where the rainfall is heary and the climate humid practically throughout the year.

Is far as vegetable growth is concerned a climate with a wellmarked dry season is, so to speak, in a condition of unstable equilibrium; the slightest variations in the soil then become of gieat importance to plant life, and it is in such regions, of which the hinterlands of our West African Colonies are the most inportant examples for the purpose of this report, that the question of forest conservancy becomes one of grave concern. Destroy the forests found there along the banks of streams, on the higher hills, and in sheltered hollows, and the country will rapidly get drier though the rainfall may remain practically the same as before the damage was done: The soil becomes no longer capable of retaining the moisture precipitated on it once the forests are removed.

Is regards the influence of forests on rainfall, reliable statistics extending over a long period are not available for tropical countries. In Europe it has been shown that forests do, but only to a very small extent, increase the annual precipitation of rain.

Quite recently, however, Mr. A. Walter, Chief Assistant of the Royal Alfred Observatory, Mauritius, has made a thorough examination of the data available with a view to investigating the effect, if any, that the wholesale destruction of the forests on the island has had on its climate. He "finds in the smoothed rainfall curves extending over the period 1860 to 1907 evidence that the cutting of the forests may have had some little effect on the total fall, but has had more effect on the number of rainy days. "The distribution through the rear is almost more important than the amount. The rainy days in the districts denuded of forests have been decreased by about 30 days per year, but under such conditions that the amount due to these 30 days is only about 6 to 10 inches, whereas the annual variation of total rainfall is often 60 inches." (See page 610 of Tol. 78 of " Nature," where a brief extract of Mr. Walter's investigations is given.)

This inquiry has, of course, been confined to a limited region (705 square miles) having an insular climate. There is every reason to believe that ihe influence of forests is much more pronounced in the case of continental areas in the tropics, where the differences between the various seasons of the rear are very marked. A reduction by one month of the number of rainy days in the year would, if established in such a climate, have very important effects on the vegetation of the locality.

The action of forests as wind-breaks is too obvious to call for further remarks; their use as barriers against the spread of fungoid and insect attacks from one series of plantations to another has of late been better recognized and adopted in tropical countries. Nixed forests of the type usually found there are amongst the most effective agencies that can be employed for such a purpose. Any tropical country that is mainly dependent on agricultural pursuits for its development camnot afford to jguore this beneficial action of forest belts. 


\section{(c) Methods of protecting forests from the dangers mentioned above:}

In all civilized countries in which attention has been paid to forestry it has been found necessary to introduce special laws for the protection of the forests and the regulation of their management. The application of such laws has, in the majority of cases, been extended to private forests as well as to those belonging to the State.

The essence of all such legislation should be the recognition by the law of forests "As pieces of property, as 'estates' of a peculiar kind." 'lo quote further from the work of an eminent authority on forest law, with reference to the above idea:

"This is not a matter of words; it is an important and most practical conception. Failure to grasp it in our colonies and in other countries too has been the cause why so little progress has been made in putting forest conservancy on a rational basis. For if you realise the idea of a forest estate to be cared for as a 'piece of property' and protected by law you will also acknowledge that a piece of property if it is to be either managed or protected must be defined as to its limits, and all questions of right and obligation arising within those limits must be settled. If that is not done the forest is still in a fluid, uncrystallized state; it hardly deserves to be called 'property' and consequently any real conservancy will be unattainable. And it will at once occur to you that if forests and other estates are to be recognized as pieces of property in the above sense, the recognition can only be made practical and operative by some action on the part of the national legislature or central authority, whereby the State, the person or body (as the case may be) who has become the owner, is protected in his enjoyment within certain local limits, and other persons are prevented from wrongful interference."

In accordance with the above principle, if any real progress is to be made in forest conservancy in British West Africa, the first thing to do is to select the best areas and make them by law (whether they belong to the paramount Government or to native communities) pieces of property, to be managed as forests. The law, in order to ensure this condition of affairs, has to provide for five main heads of legal requirement and forest administration. They are:-

"I. It separates or distinguishes from the general area of lands in the country, what are the forest estates or areas subject to the law; and it does this in several ways.

"1. It regularly constitutes State or "Reserved forest."

.2. The Indian Act creates a class of forest estates less perfectly and regularly constituted, which it calls 'protected forest.' 'The Madras and Burma laws do not recognize this, but substitute certain general protective provisions for all wooded, grazing, and waste lands which are at the disposal of Gorernment, but are not yet either made into regular forests or given up to cultivation.

"3. The Indian and Burma Acts (not Madras) contemplate the formation of village forests, forests for the benefit of villages, but under a certain degree of State control. 
"II. It provides for separating the rights of the State from those of private persons: for defining the rights, for regulating their exercise (when left in the forest), for buying them out in certain cases, and for preventing the growth of new rights or burdens to the forest in the future.

"III. It protects (in various degrees) the different classes of forest or other lands which it has made subject to its provisions by :

“1. Preventing offences and adopting measures to forestall or put a stop to accidents by fire, de.

..2. Punishing oftences, i.e., acts which it specially provides to be offences against the forest.

"IV. It extends a similar protection to the produce of the forcst and to all timber (whether forest timber or not) while in trunsit to the market or other destination.

“V. It constitutes a staft of forest officers giving them legal powers and imposing certain duties and liabilities."

I believe that the provisions for the creation of village forests have now been expunged from the Burma Forest Act as it was found that such estates were not required, the ordinary wants of the people being supplied from the State reserves and the unreserved areas.

"L'he difficulty of giving a legal definition of "a forest" has been overcome by demarcating certain areas and constituting them forest estates; in which case, of course, the areas become subject to the law. In all other cases the word "forest" is employed in its ordinary accepted sense. The above is a brief summary of the main lines on which the various Indian Forest Acts were framed.

In that portion of the Empire the bulk of the land belongs by conquest, escheat, and otherwise, to the British Government, so that no difficulty has been experienced by the State in having only limited areas from which to choose a sufficient quantity of land for the purposes of creating forest estates of the required extent. In our WVest African possessions, on the other hand, the Crown owns, comparatively speaking, little land and certainly nothing lilie the quantity of wooded area that is necessary for ensuring a continual supply of forest produce sufficient to meet all probable demands in the future. to say nothing of the extent of forests required for protective purposes in connection with the preservation and improvement of climatic factors. In fact the greater portion of the wooded areas belongs to native com. munities and chiefs, and the problem thus arises as to the best manner in which to ensurc the conservancy of a sufficient extent of forests on land the ownership of which does not rest with the supreme Government.

Provided this conservancy is absolutely ensurcd, in accordance with the spirit of the protective legal measures laid down in the Indian Forest Acts, the exact authority, manner, and agency by which it is established and enforced is a matter of but little importance and chiefly depends on administrative convenience. 
'L'he protective measures should, however, be undertaken as early as possible, because the longer they are deferred the more burdensome will become the prescriptive rights and others acquired over the land. These will eventually have to be defined, regulated, and provided for before the forests can become estates in the legal sense of the word. Until this is done the universal and populan idea, especially amongst natives, that the forests generally belong to no one in particular and that, with certain exceptions, almost anyone is entitled to a share of their produce will continue to prevail, and in the end result either in great difficulty being experienced in limiting the rights acquired by custom or in the latter becoming so extensive as to hardly make it worth while attempting to regulate them, and the forests as such will then, for all practical purposes, cease to exist.

Indeed the very existence of numerous rights (especially those to the collection and utilization of forest produce) of this character is a certain indication that the forests are much wanted by the local right holders (in West Africa usually the members of the native communities jointly owning the land), and it then becomes the duty of the paramount Government to see that these rights are satisfied both in the present and in the future. This can only be done by ensuring the preservation and increased productiveness of the particular forests concerned, and before that is possible it is absolutely essential to have the legal position of the latter clearly defined as to the ownership, boundaries of the land, and the extent and nature of the rights existing over them. Half measures in this respect are exceedingly unsatisfactory and end, owing to the umestricted damage done to the forests, by the latter ceasing to satisfy, and thus causing injury to the rery rights that it is intended to protect.

Hence, in the interests of the native communities themselves, quite apart from other considerations, it is highly desirable to secure the continuous and prosperous enjoyment of such rights, and for this purpose alone, if for no other, it becomes incumbent on the paramount Government to ensure, either directly or indirectly, the legal protection and proper management of the forests.

In this connection I cannot do better than quote the following from the work of B. H. Baden-Powell on forest law :-

"There is not the least doubt that in the process of time every forest area (whether called 'protected' or not) in which various undetermined rights of user exist and in wich the matters above specified [viz., clear and defined boundaries, a settlement of rights -an authoritative decision as to what rights have to be exercised and to what extent, and a prohibition against all unauthorised diminution of area and abuse of the soil and growth, as well as against the gradual growth of new prescriptive rights] are not arranged will in time diseppear off the face of the country. It may take a century to do it, but the deterioration and ultimate complete destruction of such places is as certain as anything can be."

A misconception of this real nature of the meaning attached to the words " reserved forests" or "forest reserves" has, in some 
cases I know of in one of our West African Colonies and Protectorates, led to great difficulties in ridding the areas of burdensome rights acquired after the areas were obtained from the native authorities (by lease) and declared to be reserved forests. In one case the actual existence of the forest itself is rery seriously threatened by the large number of settlements that were allowed to spring up within its boundaries. The importance of clearly defining the boundaries of, and the extent and nature of anr rights existing within, an area that is to be permanently managed as a forest estate cannot be too strongly emphasised. Failure to ensure its legal status invariably results in a large crop of vague, undefined rights that eventually orerburden and destroy the dominant estate.

Rererting now to the possible methods by which such conservancy can be ensured in our West African Colonies, it is adrisable to recall the main purposes for which forests are required in those regions. They are :

1. As means for protecting and farourably altering the climatic factors.

2. For a constant and sustained yield of forest produce especially with a view to satisfying future increased demands.

3. For supplying wooded areas suitable for the exercise on them of those methods of practising agriculture now in rogue amongst the natives.

The last is an almost unirersal use to which such areas are put by not very highly civilized native tribes inhabiting the tropics. It is a native custom, and howerel wasteful and destructive it may be, as far as the forests are concerned, it should be respected till such a time as the tribes have been induced to adopt more modern and less wasteful systems of agriculture. The custom in West Africa is something with much more defined rights of a proprietary nature about it than the rague ownership claimed by nomad tribes practising shifting cultiration in other parts of the world where they return to the same area only, if ever, after a very long number of years.

On the Gold Coast and in Southern Nigeria the fellings of the bush are carried out in a more or less regular rotation, the latter extending over periods from three to twelve years in duration, and are sometimes confined to restricted areas, the limits of which are well recognised amongst the natives themselves. Unfortunately, however, there is a great tendency on the part of the inhabitants of those countries to alter from time to time the sites of their villages, especially the smaller ones, and the result is that new centres of forest areas are being constantly involved in destruction. It should be noted that the essence of this system is its wastefulness and large extent of land required in comparison with the wants of even moderately intensive cultivation. In India and Burma no difficulty is experienced in practising permanent cultivation, and it is almost the universal method adopted there. As a general rule the only extensive patches of really old forest now left in British West Africa are situated on land the ownership of which has been disputed amongst the tribes, or which are in places inaccessible to cultivation. 
In West Africa, then, the greatest danger threatening the existence of the forests is not their orer-exploitation for forest produce, but their wholesale destruction for farming purposes, and this is proceeding at a very rapid pace, so that no time is to be lost if sufficient old forest to meet all likely requirements is to be protected and maintained. With the land tenures in force in that part of the world, it is hopeless for the paramount Government to expect the handsome revenues from forest estates that are realized by the Indian Goremment, to which the bulk of the forests in that country belong. In our West African Colonies the best policy to adopt in matters of forest administration would rather appear to be that of selecting and managing for, and more directly with a view to their own pecuniary interests, the best wooded areas belonging to the native communities that we have to deal with. If this principle is adopted and practised I anticipate but few difficulties in getting the native tribes to agree to our managing the forests for them. The essence of such a method is, of course, the tangible and obvious recognition in the working of the system of the native rights to the land and its produce, for this is a point in regard to which the tribes are exceedingly sensitive and jealous.

Nevertheless, it is always advisable for the paramount Government to recognize, and, if necessary, in particular instances to act upon, the principle that where the interests of the public in general are concerned with regard to matters of forest policy it has the right to interfere, if by so doing it can ensure the adoption of any measures that are necessary for the public good; but even in such cases the advisability of sharing with the natives any revenues derived from the renture should not be overlooked. This right of the supreme authority to interfere, when necessary, in the interests of the public welfare, with forestry matters, is recognized. in every civilised State that has had to deal with questions of forest administration, and moreover it is being constantly practised with regard to private forests and those belonging to communes, municipalities, \&c., and feudatory native States. Examples of circumstances calling for such direct interference on the part of the supreme Government are, of course, dependent on the inability of, or direct refusal on the part of, the bodies concerned, whether they be municipalities, corporations, communes, native communities, protected states, or even private individuals, to carry out the measures required.

Whenever it is necessary for the good of the public to protect extensive forest belts with a view to preserving or improving the climatic factors of the locality or to act as protective barriers against other dangers, the direct interference of the State is justifiable if the measure cannot otherwise be ensured; and the same holds good in the matter of preventing the extermination of valuable species of plants and otherwise regulating their exploitation (both as regards major and minor forest produce) when this is desirable for the public welfare of the countries concerned. The necessity of such interference from the Imperial standpoint becomes obvious when it is recalled that the protection or destruction of certain forests in, say, one native State may be of rital importanre to the inhabitants of adjacent or even remote States 
when the same river flows through all of them, and the forests in question are situated at the sources of the stream (which latter may not, in the particular State in which they are situated, be considered of much importance) the waters of which are required for such purposes as irrigation, navigation, \&c., in the other States. Similar examples occur when the existence of an article of forest produce which, though of great demand in many States, is only to be found in one or a few of them, is threatened br overexploitation or the reckless destruction of the forests.

Adopting the principle, then, that the native communities are entitled, except in the case of Crown lands or others leased from the natives under conditions that do not imply the exercise of this obligation, to a share of the revenues derived from the rooded areas managed as forest estates, the chief measures to adopt with a view to ensuring forest conservancy are :-

(a.) The enactment of a principal proclamation, ordinance, or whatever else it may be called, that empowers the Governor in Council to regulate forestre matters generally within the limits of the colony and protectorate, and provides, amongst other things, for the legal constitution of reserved forests.

(b.) The passing of "orders" and "rules" under the above authority from time to time, as the necessity arises, with a view to making the provisions of the principal enactment operative.

(c.) The employment of executive measures with a view to selecting and managing the areas required as reserves, and for the purpose of supervising the application of the rules and orders and enforcing them.

Before proceeding to a detailed consideration of the proclamation, orders, and rules that are required for the purpose of establishing forest conservancy on the Gold Coast, it will be convenient to mention briefly the manner and agency by which it has been provided for in the different feudatory and dependent States of India in which the British Government is either not the general owner of the land, or, if it is, does not exercise the privileges of ownership.

Taking the extreme case of native chiefs in the N.W. Himalayas, where the law of British territory does not apply, and where some excellent timber forests exist which it was very desirable to protect, the latter were leased by the chiefs to the British Government either for a long term or in perpetuity. The forests are managed by forest officers of the Indian Government, and all arrangements regarding rights of user and penalties for forest offences, \&c., are carried out under the lease, the chiefs agreeing to enforce rules.

Again in the case of the mative States near Simla and in Cashmere the chiefs have by agreement and under the influence of the political officers been inducer to "allow or undertake a certain conservancy.'

The hest example perhaps, howerer, for the purpose of this report is the case of the Southern Shan States of Burma which, 
though technically a part of British India, are administered by the Shan Chiefs or Sawbwas under the general supervision of the chief political officer, known as the Superintendent of the S. Shan States, and his assistants.

Is I was for several vears in charge of the forests of these States, and was in part instrumental in eventually getting their management put on a sound footing, I had ample opportunities of seeing how the arrangements worked. The Sawbwas are allowed to govern their own States subject to certain restrictions regarding the more serious criminal offences and civil suits in which property over a certain value is involved: such cases are brought to the courts of the political officers and are tried there, or, if tried in the native courts, the judgments are revised and confirmed or not, as the case may be, in the British courts. The chief political officer also controls the amount of revenue raised, its allotment to the different heads of expenditure, and the manner in which it is utilized. Each State submits an annual budget estimate, which has to be confirmed by the superintendent before it can be used as a basis to work on. Otherwise the chiefs have complete control over the management of their States, and their customs are not interfered with unless they are repugnant to civilized ideas of law and justice. The British Government exercises a certain amount of control over the succession of the native chiefs.

In all these resperts it will be seen that the Shan States are in rery much the same position with respect to the suzerain power that our protectorates in West Africa are.

Now, as regards forestry in those States, the Upper Burma forest regulation No. T. of 1908 was, during my tenure of office as Divisional Forest Officer for those States, in theory applicable to them, as they formed part of the territories of Upper Burma, but in actual practice only a few rules relating to the protection and regulation of the exploiting of teak timber, which in Burma is a " Royal tree," and as such the property of the British Government, were directly applied to them; they were in respect of the other rules framed under the regulations especially exempted from their operations. The paramount Government thus, whilst formally reserving to itself the right (in the regulations, which correspond to the principal ordinance or proclamation of our West African Colonies and Protectorates) to control the question of forest conservancy in the States, actually did not do so, except in the few cases indicated above. Nevertheless, as the measures for legally creating reserved forests are contained in the principal enactment itself and not in the subsidiary rules, they were always directly applicable at any time when, on the arlvice of the forest officer in cluarge, it appeared desirable to take up any particular wonded area as a reserve. Since I left that comntry the pines, P'. Thasya and P. Merkusii, extensive forests of which exist in those States, and the protection of which was urgently called for, have been declared as "reserved trees" and specially protected under the forest rules. Al] other measures of forest conservancy were carried out by the chiefs themselves under the advice of the divisional forest officer, backed up, if necessary, by that of the 
superintendent, who occasionally had to exercise considerable pressure to ensure their adoption. The arrangement eventually come to, partly by means of legal enactments and partly by administrative steps, pure and simple, was in brief :-

1. That the Sawbwas administered the forest laws in their States and maintained subordinate forest establishments for that purpose, which were in certain matters under the control of the divisional forest officer.

2. The latter with a suitable staff of Europeans and natives to help him exercised general supervision over the protection and management of the forests, more especially with a view to seeing that the native establishments maintained by the chiefs were carrying out their duties in an efficient manner.

3. All forest taxes and the revenues derived from the sales of timber were collected by the supreme Government, and the net proceeds divided up in the following proportion :-

$\frac{1}{3}$ to the British Government.

$\frac{2}{3}$ to the native chiefs.

Under this system the annual forest revenue went up by leaps and bounds during my tenure of office. It was Rs. 15,000 when I assumed charge of the division, and Rs. 120,000 when I left at the end of six years, and the chiefs in the end were more than satisfied with the arrangements. It seems to me that such an arrangement, by which Government reserves to itself, in the principal enactment, the right to interfere in matters of forest policy and administration whenever it is absolutely necessary to do so, yet at the same time allows considerable freedom on the part of the chiefs and native communities to carry out the necessary measures in their own way, is well suited to the requirements of our West African colonies.

The forest laws of old Southern Nigeria were based on this conception of the extent to which the suzerain power should interfere in matters of forest administration in that Protectorate. In these laws, as will be seen presently, native rights and customs were adequately safeguarded, and the principle was recognised all through that the chiefs and communities were entitled to a share of the taxes levied on, and other profits accruing from the exploitation of, forest produce. Unfortunately, when the amalgamation of the Colony and Protectorate of Lagos with old Southern Nigeria took place, it was found that the forest proclamation enacted in the former, though otherwise more or less suitable for local requirements, was completely nullified in its operations by containing a clause that left the decision as to whether the laws were to come into force in any particular native State with the communities themselves as represented by their respective native rouncils. Government thus virtually abandoned all control over directing and determining the forest policy to be pursued in those countries.

It now rests, from the legal point of view, with the native councils alone to decide whether forest conservancy, which is preeminently concerned with the public welfare and good of those 
countries, is to be adopted or not. It is true that some good can be and has been done by the district commissioners and political officers in getting the chiefs to make some attempt at preserving the forests, but this is an uncertain method by which much is left to chance and the personal influence exercised by a few officials, and in any case is a slow process; meanwhile the forests are being rapidly destroyed. It may be confidently asserted that no real progress has or ever will be made in forest conservancy unless the supreme Government reserves to itself the rignt to direct and regulate its application. The measures necessary for the realisation of sound forest administration are difficult enough, as it is, to put into practice when undertaken directly by Government itself; the results likcly to follow from leaving such measures to the caprice of the native councils can be imagined.

In none of the ordinary affairs of life is that continuity of policy and action required for the realisation of sound administration of such vital importance as it is in forestry. It is the very life and essence of its successful application.

Forest crops often require centuries before they mature and can be reaped. The majority and best of the various approved methods of treatment and arrangement cannot be realised before generations have lapsed, and in most cases not within the lifetime of the persons initiating them. The longer the interval between the sowing and reaping of the crop the greater the opportunity and temptation to interfere with its growth, and the greater the chances against its ever maturing under any particular method of treatment. Again, the temptation for private individuals, communes and such bodies to reap prematurely the crop at the expense of the generations to come is very great. For all these reasons it is recognised in civilised States that the supreme power is the only agency suitable for directing and carrying out a sound forest policy.

In short, nothing but that grim tenacity of purpose and action that can alone be exercised by the paramount Government can ever safely carry the forests through the dangers and vicissitudes to which they are exposed during the long years that must elapse before they can be reaped and brought into an organised condition capable of ensuring a sustained and increasing yield of produce in the future.

D.-Forest laws suitable for the Gold Coast and its two dependencies, Ashanti and the Northern Territories.

For our WVest African Colonies and Protectorates I think the most suitable kind of forest legislation is that embodied in the Forest Laws contained in pages 1312 to 1344 of Volume II. of-

"Laws of the Colony of Southern Nigeria," edited, by authority, by E. A. Speed, M.A., LL.B., AttorneyGeneral of the Colony of Southern Nigeria, and J. E. Green, Solicitor-General of the Colony, 1908; published by Stievens \& Sons, 119 and 120, Chancery Lane.

The laws are based on those of the Indian Forest Acts, and have been modified to suit local requirements. They have been 
simplified, and are not so elaborate in character as the Indian ones. They contain all that is necessary, for the present, to put Forest Conservancy on a sound footing within our West African Territories, and as mentioned above the success attending their application will depend mainly on the method and agency by which they are directed and enforced. As long as Section 21 of the Southern Nigeria Forestry Ordinance remains in force, no real progress can be expected, as the question of accepting or rejecting the laws depends, in accordance with the powers given in that section, on the will of the native communities as expressed by their councils, and, in some cases, on the personality of the political officers. This arrangement involves an uncertainty and reliance on chance that is absolutely fatal to good forest administration.

The exact legal or administrative machinery necessary for applying the forest laws is a matter of convenience and choice resting with the particular administrations concerned, and is immaterial as long as it is recognised that the enforcement of the main provisions for conserving the forests should not be left to chance, but, on the contrary, absolutely ensured. The native councils possess neither the knowledge nor the experience that is essential for coming to correct decisions on such broad questions affecting the general and public welfare of the whole country. If sufficient pressure can be, and is actually, when necessary, employed, without resorting to direct legal interference with the powers of the native councils, to accomplish the conservancy called for-well and good. But the history and past experience of such methods of enforcing forest rules show that they have invariably been followed with but little success.

In Sections IV., VII., and VI., respectively, of the three Orders of His Majesty the King in Council, dated the 26th September, 1901, viz., the Gold Coast Order in Council, the Ashanti Order in Council, and the Northern Territories Order in Council, the Governor of the Gold Coast is given the power to provide by Ordinance "for the administration of justice, the raising of revenue, and generally for the peace, order, and good government" of those Possessions.

As Forest Conservancy is above all things a matter concerning the welfare of the inhabitants of those countries, and is undoubtedly of benefit to the public, there appears to be sufficient legal authority for carrying out such arrangements as are necessary to establish it. One would certainly include it amongst the measures necessary for good government.

The Southern Nigeria Forest Ordinance, orders, and rules are, with some modifications that will be suggested presently, suitable instruments for ensuring the amount of Forest Conservancy necessary on the Gold Coast during the immediate future.

Taking these enactments in order, I will briefly indicate the modifications and additions that appear desirable in order to meet the requirements of the Gold Coast, Ashanti, and the Northern Territories. 


\section{The Southern Nigeria Forestry Ordinance.}

(No. 14-1902, and Proclamation No. 28-1901, with subsequent amendments-see pages 1312 to 1319 of the new 1908 edition of the laws of that Colony and Protectorate.)

This, as modified below, should apply to all three of those Administrative Divisions of the Gold Coast.

Sections 1, 2, and 3 of the Ordinance can remain unaltered, as they deal with definitions and the power to appoint officers to carry out the provisions of the Ordinance. The definition of "native lands" should be made more comprehensive and clear by adding the words "unoccupied and uncultivated" after the word "waste."

Section 4.-Another sub-section should be added to this, to the effect that the Governor can, whenever it may appear desirable in the interests of the native communities concerned, of the public, or of both, to constitute any waste native land Native Forest Reserves, on the following conditions:-

(a) That the Reserves are constituted more particularly for the benefit of the native communities owning the land.

(b) That they shall be managed by Government agency or under its supervision with that object, and that the Governor may make rules for regulating this management of Native Forest Reserves, prescribing the conditions under which the forests may be exploited and the community or group of communities for the benefit of which any such forest is constituted may be provided with forest produce or with pasture, and their duties in respect of the protection of such forest.

(c) That the net profits (i.e., after the cost of management has been deducted from the revenues) shall be paid to the native communities owning the land which has been constituted a Reserve.

(d) That the titles to the ownership of the reserved lands are not altered by such reservation.

In suggesting these additions to Section 4, I have endeavoured to distinguish between the following ideas, and to provide for their expression in the Ordinance:-

(1) That whenever the necessity arises for doing so, in the interests of the native communities and of the general public, the Government should exercise its prerogative as the paramount Government of making certain by legislative measures of being able to establish the Conservancy of any particular forest growing on lands owned by the natives, and to do this without disturbing their titles to the ownership of the land. Such areas would then, of course, have to be in fairness managed for the benefit of the native communities concerned.

(2) The acquisition of land for reservation by special agreement with the native communities, under the conditions embodied in the agreements, these conditions not necessarily being such as to preclude Government from managing the Reserve mainly for its own particular purpose or in the general interests of the Colonies. 
The main difference between the two arrangements is that in the former case the reserration may be compulsory, as far as the natives are concerned, whereas in the latter case it is optional.

Section 5.-This may stand.

Section 6.-Ditto. This provides for the determination of any rights affecting the land that it is proposed to reserve.

Section 7.-To stand as it is.

Section 8.-Ditto.

Section 9.-Ditto.

Section 10.-This will require some modification in the case of Native Forest Reserves (vide the addition proposed to Section 4) to the effect that the titles to the ownership of the land on behalf of the native communities claiming them shall be enquired in io and defined.

Section 11.-To renrain unaltered.

Section 12.-The order constituting the land a reserve should also state whether the land has been acquired by agreement, lease, \&c., or under the powers given the Governor in the additional sub-section to Section 5 (proposed by me) for constituting Native Forest Reserves.

Section 13.-To stand, but the titles of the native communities to the ownership of the reserved land must be omitted from the rights that become extinct.

Section 14.-To stand.

Section 15.-Ditto.

Section 16.-Ditto.

Section 17.-Should be modified in accordance with local requirements as to who the most suitable officials are for the purposes of this section.

Section 18.-To stand.

Section 19.-Ditto.

Section 20.-Ditto.

Section 21.-Omit the clause in which the native councils are given the power to accept or reject any orders and rules passed under the Ordinance. See my remarks on pages 113-115, re this clause. Also alter the last paragraph of this section, to the effect that all rules and orders shall apply to all Crown lands and lands leased or held by the Crown, except to Reserves, unless the orders or rules are specially declared to apply to Reserves. The latter require a more thorough protection than non-reserved areas, and are put under a more elaborate management.

Section 22.-To be modified in accordance with local practice and requirements.

Section 23.-To stand.

Section 24.-Ditto.

Section 25.-Ditto. Omit reference to Section 21. 


\section{The Scriedule.}

\section{1.-Rules relating to Rubber.}

The Southern Nigerian Rules should, with the modifications indicated below, be applied to the Gold Coast Colony and Ashanti, but not to the Northern Territories, as but little is known about the rubber-producing plants of that region.

Rules 1 and 2 of the Rules may stand.

Rule 3 should be modified to suit local arrangements.

Rivule 4 should be altered to the effect that these Rules do not apply to Reserves, which, as I have mentioned before, should be manarged under rules specially framed for that purpose.

Ruie 5 to stand; the titles of the officials mentioned in the Rule may require alteration in accordance with local procedure.

Rule 6.-To stand.

Rule 7.-Ditto.

Rules 8, 9, 10, and 11 can stand ; the title "District Commissioner" may be replaced by the general term "Commissioner."

Rules 12, 13, 14 ean remain unaltered.

Rule 15.-The minimum girth may, I think, be reduced to 24 inches.

Rule 16 should be completely altered and replaced by one in which the following are provided for instead:-

(1) That the trees are not tapped during the months December to. June.

(2) That under no circumstances should the cuts penetrate deeper than the cambium layer, and on no account must they enter the wood.

(3) No tapping shall be done higher up the tree than 12 feet from the ground.

(4) That tapping be undertaken only in the early morning, and not later than nine o'clock, provided that on cloudy or rainy days, when the sun is obscured, it may be carried on up to a later hour.

(5) That the system of tapping followed is that known as the "half herring-bone" method, which may be described as follows:-

A vertical, very shallow channel, not more than $\frac{1}{4}$-inch wide, is cut from the base of the tree up its trunk to a height not exceeding 12 feet. From this channel, branch channels are cut at an angle of $45^{\circ}$ with the main channel, and on one side only of that channel. The branch cuts should be at intervals of 6 inches, and should not go more than a quarter round the tree. 
(a) When the wounds caused by making one complete series of cuts, as described above, have completely healed, another series of tappings can be carried out on the opposite side of the tree, and, when these in their turn have healed, on one of the two remaining sides of the tree that have so far not been tapped. The fourth series should then (after the cuts from the third series have completely healed) be carried out on the remaining uncut side. Subsequent tappings on each section of the trunk should be carried out so as not to tap any portion of the bark a second time until the whole of the untouched surface of the bark on that section has been tapped. The tappings, of course, should on each occasion be limited to the proper season of the year.

Experience has shown that complicated methods are, in the absence of adequate supervision, unsuited for the tapping of wild trees growing in the forest, however desirable such systems may be for plantation trees where the operations can be properly directed and checked. Funtumia elastica is, in comparison with the Para rubber tree, far less resistant to injuries caused by tapping, and, consequently, such operations should be carried out very lightly on it, special care being taken not to cut down to the cambium zone of tissues. For this reason, the method of removing successive thin shavings of bark off the sides of the channels on alternate days is to be discouraged.

Rule 17 should be abolished, and the following substituted for it:-

Vines are not to be tapped during the period December to June. In tapping them the stem should be severed by a clean cut flush with the ground and the latex then collected from the severed portions of the vines by cutting the latter into small sections and collecting the latex from each piece.

The latex collected from vines must be strained through muslin or wire ganze or otherwise cleaned in order to get rid of extraneous matter before it is coagulated.

Rule 18 should be modified to the effect that on no account are the latices of Funtumia elastica, Ficus Vogelii, and Landolphia owariensis to be mixed one with another, and the mixtures then coagulated for the preparation of rubber. Each of the three kinds of latex must be kept pure and coagulated separately. Any licence-holder found guilty of preparing rubber adulterated with dirt or other extraneous matter, or actually found preparing rubber from latices mixed with those of the three species men. tioned, will be liable to have his licence forfeited.

Rule 19 should, I think, be abolished, as experience has shown that with proper management and encouragement the native communities, as a rule, readily undertake such planting operations.

Rule 20 should stand, but the licence fee should be a nominal one, sufficient to cover the cost of printing the licences. The royalties payable to the native communities, however, should remain unaltered. 
Rule 21 can stand.

Rules 22, 23, 24, 25, and 26 can stand.

Form A (Rubber Licence) should stand.

With regard to the difficult problem of ensuring the preparation of a purer grade of rubber, and putting a stop to the large amount of adulteration of that product that is at present practised, the following methods of dealing with it may be mentioned :- -

(1) Prohibit the export of inferior grades. This is most easily done by imposing a prohibitive export tax on the poorer qualities.

(2) Enforce the Adulteration of Produce Ordinance, and confiscate all impure rubbers.

(3) Prohibit the tapping of all latex-yielding trees other than I'untumia elastica, Landolphia owariensis, and Ficus Vogelii for the purposes of preparing rubber from the latex.

'The drawback to all these methods is the fact that the inferior' grades of rubber are readily saleable, but at a reducerl price, in the home markets, and it becomes a matter for serious consideration whether it is advisable to interfere with an established trade of that sort. The real remedy, of course, lies with the merchants who purchase the produce from the natives. They can, if they combine together, easily effect a very great improvement in the quality of rubber offered for sale, by simply rejecting the inferior kinds.

Something can also be done by teaching the native better methods of preparation, but no great success is likely to follow such measures, as the main practice objected to is the act of adulteration, which the majority of natives know very well, without being taught, to be detrimental to the quality of the rubber. Besides, the adulteration is very frequently carried out with the direct intention of cheating.

Some good may be done under Rule 18 (as altered in this Report), because the fear of having their licences confiscated may induce some of the collectors to abandon this practice.

In the French West African Colonies, the different grades of rubber are sorted at the port of shipment; they are put into separate bags, which are then sealed up and the grade or quality distinctly marked on them before they are exported. The very inferior grades are often completely rejected by the Government inspector's.

There is no objection to the latices of species rielding an inferior product being mixed together before coagulation is brought about, but it is highly desirable to keep the latices of Funtumia elastica, Landolphia owariensis, and Ficus Vogelii quite pure and separate one from the other.

As any arrangements that may be made for regulating the exploitation of rubber will necessitate the employment of a fairly 
large staff to carry out and supervise the measures necessary for raising the quality of the rubber and protecting the trees against over-exploitation, the advisability of imposing a small export tax on rubber should be carefully considered.

The average annual export of that produce, computed from the figures of the last nine years, is $3,511,332 \mathrm{lbs}$, valued at $\$ 316,995$. An export tax of one halfpenny per lb. would on this quantity bring in an average revenue of $£ 14,630$. The average value of the rubber exported during those years is $1 s .9 d$. per lb., which makes the incidence of taxation equal to $\frac{1}{42}$ of the value, or a little under 21 per cent.

Such a tax would, of course, fall unequally on the different grades, but it would tend to improve the quality of the poorer kinds, and thus help to raise the general average quality all round. Moreover, it is a very light tax, that can be easily borne without interfering with the trade; and its collection would present no great difficulty. For these reasons I strongly advise the adoption of this method of raising revenue. The rubber trade is of great importance to the Colony, and it is not asking too much of it. (the trade) to pay a small tax such as this in order to improve the quality of the produce and protect the trees from destruction.

We now come to

D. The Orders setting forth the acts prohibited under Section 18 of the Forest Ordinance.

Para. (1).' The species mentioned here should be replaced by the following:-

(a.) All species of maloganies of the geuus Khaya (native names Dubini and Kwabaho).

(b.) All species of cedars of the genus Pseudocedrela (native names Penkwa or Punkwa, and Tiama-Tiama).

(c.) The Odoum or Iroko (Chlorophora excelsa).

(d.) The Baku (1Kimusops Djave).

(e.) The Kwatanuro or Pebedum (Lovoa Klaineana).

(f.) Cedars belonging to the genus Guarea (native name Bossè).

(g.) The Kaku (Lophira sp.).

The paragraph about ebony should be omitted.

The above list contains all those species of trees that yield timber of the first quality, fit for export to Europe, and that it is desirable to protect against over exploitation.

A clause should be added to this paragraph to the effect that the owners of native lands cannot "take" timber for export except in accordance with conditions prescribed in the timber rules. The concluding sentence but one of para. (1) of the Soutbern 
Nigerian Order will require correction in accordance with this alteration.

Para. (2.) Replace the list of plants mentioned here by those I have mentioned above, and add the following:-

(a.) F'untumia elastica.

(b.) Landolphia owariensis.

(c.) The oil-bean trees, Pentaclethra macrophylla (native name Athawah), Ricinodendron africanus (native name Awama), and trees of the genus Carapa.

(d.) Gum copal trees of the genus Cyanothyrsus (native name Hyedua).

(e.) The shea butter tree (Butyrospermum Parliii).

The remaining paragraphs (3), (4), (5), (6), and ( $(\tau)$ of the Order can stand.

The above Order thus modified would he suitable for the Gold Coast and Ashanti. For the Northern l'erritories I would substitute a simple one somewhat as follows.

The following acts are prohibited:-

The taking on native lands of the mahogany tree (Khaya senegalensis), the cedar (Pseudocedrela Kotschyi), the shea butter tree (Butyrospermum Parkii), the Opapao (Afzelia africana), and Landolphia owariensis for use in the Colony and Protectorates of the Gold Coast, except in accordance with the rules relating to timber for the time being in force.

So very little is known about the rubber-yielding plants of the Northern Territories that I have not attempted to protect them under the Order. The question can be deferred till more information about the species and the trade done in rubber in those countries has been procured.

Meanwhile the protection suggested above for the best three timber trees and the shea-butter tree will suffice. It may be necessary to add to the list of timber trees in the future when more is known about them. The sass wood tree (Erythrophloeum guineense) and the balsam copaiba tree (Daniella thurifera) may, if necessary, be added to the list of protected trees, as they both yield useful timber.

\section{Rules Relating to Timber.}

These Southern Nigeria rules appear suitable for the Gold Coast of Ashanti, and should be adopted for them with the following modifications. The titles of the officers referred to in the rules can be altered in accordance with local requirements and custom. I have not attempted to correct them.

The rules that require to be modified are:-

Rule 20.--Alter sub-section (1) (a) as follows:-

"The girth of the tree at a height of 4 feet 6 inches from the ground, or, when it possesses buttresses, at the level at which they all merge into the stem" 
Rule 25.-Alter as follows:-

"No mahogany trees of the genus Khaya (known to the natives as Dubini and $K$ wabaho), and no cedar trees of the genera $P$ seudocedrela (known to the natives as Penkwa, Punkwa, and TiamaTiama), and Guarea (native name Bossè), and no tree of the species Lovoa Klaineana (native name Pebedum), and no tree of the species Baku (1/imusops Djave), and no trees of the genus Cyanothyrsus (gum copal trees, native name Hyedua), and no tree of the species Chlorophora excelsa (Odoum of the natives) of a less girth than 12 feet at a height of 4 feet 6 inches from the ground, or, when buttressed, at the height at which the buttresses merge into the stem, and no trees of the species Funtumia elastica, Pentaclethra macrophylla (the oil-bean tree, native name Athawah), Ricinodendron africanus (native name Awama), and trees of the genus Carapa of less than 6 feet in girth at a height of 4 feet 6 inches from the ground, or, if buttressed, at the height at which the buttresses merge into the stem, shall be felled: Provided that the Governor may by Order reduce these dimensions jn any district or locality named in such Order, where the trees do not attain such dimensions."

This rule protects undersized trees of the above-mentioned species against felling by timber licensees.

Rule 38.- The fees payable on application for a timber licence and on execution of the same should stand.

Rule 39. - The fees payable under (a) for mahogany and cedar trees should be altered as follows:-

$\begin{array}{llllll}\text { (1) For each mahogany tree } & \ldots & \ldots & \ldots & 50 s .\end{array}$

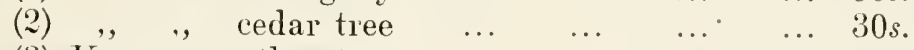

(3) Upon any other tree $\quad \ldots \quad \ldots \quad \ldots \quad \ldots \quad \ldots 20 s$.

The rest of the rile in question can stand as it is.

Rule 40.- Omit the words "inspection fees" from the first sentence of this rule;

And replace $(a)$ and $(b)$ by the following:-

(a.) "Three-fifths of the fees (i.e., 30s. in the case of mahoganies, 18s. in the case of cedars, and 12s. for other species) for any of the above-mentioned trees shall be paid into the nearest local treasury, and shall form part of the revenues of the Colony.

(b.) "Two-fifths of the fees (i.e., 20s. for mahoganies, 12s. for (eelars, $8 s$. for other species) payable on mahoganies, cedars, and other species of trees shall be paid to the Commissioners of the districts in which the lands included in the licence or the greater part thereof are or is situated and distributed by them among the grantors of the licence in the proportion to which they are entitled."

Sub-section (c.) of this rule can stand.

In Rule 39 the fees have heen charged per tree instead of per $\log$. Experience has shown in Southern Nigeria that the former arrangement prevents the wholesale waste of timber that used to go on when an export tax per log was charged. Trees of the prescribed girth used to be felled right and left, and only one or two 
of the choicest logs were selected from each for export, the balance were left to rot in the forests. Sometimes no $\operatorname{logs}$ at all were selected from the felled trees, and the latter needlessly destroyed and their value as seed bearers lost to the forests.

Similarly, experience has shown that in the case of mahoganies, cedars, and the Odoum (Chlorophora excelsa) the average yield of logs per tree of individuals possessing a larger girth than 12 feet is three, and the Government's share of the revenue is based on the all-round sum of $10 \mathrm{~s}$. per $\log$ of trees belonging to those species. Including the share that goes to the native communities (grantors of the licence), the incidence of taxation amounts to 16s. $8 d$. per log, which is by no means heavy, as the following estimate will show.

It is based on low figures for the superficial contents of the $\operatorname{logs}$, their lengths, and the price obtained in the home markets. Experience has shown that trees 12 feet and over in girth yield at least three logs of the low dimensions given below-viz., logs 10 feet in circumference, or, what amounts to the same thing, logs having the sectional area equal to that of a circle of the abore circumference.

The length of such a log would on the average exceed 16 feet, but the latter figure will be taken so as to give the merchants the benefit, and the cubical content would in each case equal $\left(\frac{10}{4}\right)^{2} \times$ 16 cubic feet, which is equal to 100 cubic feet. This is equivalent to 1,200 superficial feet. As the merchant gets credit at Liverpool for only two-thirds of the total superficial contents of a $\mathrm{log}$, he will be paid only for $\frac{2}{3} \times 1,200$ or 800 superficial feet. Now fair all-round mahogany and cedar wood sell at an average price of $3 d$. per superficial foot, so on this assumption the merchant will realise $£ 800 \times \frac{3}{12} \times \frac{1}{20}=£ 10$ per $\log$, on which he has to pay a tax of $16 s$. $S d$. This amounts to an incidence of taxation equivalent to $\frac{16 \frac{1}{2}}{20}$ or $8 \frac{1}{4}$ per cent.

With larger logs and the same price the taxation would be lighter, but the case has been purposely put in the worst possible light from the point of view of the merchant to show that even under those conditions the tax is by no means an excessive one. I think in actual practice it will be found to be about equal to a 5 to 6 per cent. ad valorem tax.

Of course, the imposition of such a tax will be strongly opposed by timber merchants of the Gold Coast, but it has been found to work very well, despite protests on the part of the merchants, in Southern Nigeria, and timber concessions are as eagerly sought for there now, since this duty was levied, as they were before under the old rates. These woods are a valuable asset to the natives and the paramount Government, and are worth to them as sources of revenue every bit of the tax proposed. Another point is that the timber industry of the Gold Coast is greatly in need of being placed on a sound footing; at present a large number of undesirable persons of little or no financial stability, and who have in addition become heavily involved in mining speculation, are engaged in it, and have given it that hand-to- 
mouth character inseparable from the conditions mentioned above, in the wake of which has followed the theft of timber which is so much complained of and which is practically absent from Southern Nigeria. The imposition of the proposed tax will help to weed out the undesirables and regulate their operations on a more satisfactory basis.

Another danger in fixing the Gold Coast timber tax at a lower figure than that in force in Southern Nigeria is the probability in such an event that attempts will almost certainly be made to bring pressure to bear on the Government of the latter in order to reduce the tax in force there. I have already explained that the Southern Nigeria arrangements are working satisfactorily, and that no changes are called for at present.

As there is certain to be an outery against the high minimum felling girths of 12 feet proposed for some species in Rule 25, it is advisable to mention here the reasons that have necessitated the adoption of that size.

I have, when describing some of the forests of the Gold Coast and Ashanti, called attention to the unsatisfactory condition of the age classes, or gradations, of the more important species to be found in them.

Now in order that a forest should yield an approximately equal quantity of major produce (timber) every year in the future, it is necessary that it should, as near as possible, be in that condition known technically as the "normal forest," in which the age gradations, or what amounts to the same thing as the girth, are for all practical purposes proportional to the age, the girth gradations are so represented in the numbers of trees and the volume they contain as to enable that annual yield of mature timber to be realised. Any deficiency in the "normal" number of trees that should exist in each girtl class, especially those corresponding to the younger age gradations or classes, necessitates an alteration in the annual yield so as to enable the surplus stock in the well-represented classes to be utilised in such a manner as to permit the fellings to tide over the long period necessary before the forest can be converted into the normal state. Now the majority of the West African forests are in the irregular condition in which the age or girth classes are not evenly graded, large gaps occur in the gradations, and some of the latter, especially the older ones, are, on the other hand, represented by a greater number of trees than is necessary; hence if the yield was based on this last factor alone, without considering the abnormal condition of the younger classes, more than the amual wood increment would be removed, and the wood-producing capital would be encroached upon. In fact the greater the deficiency in the younger classes as compared with the older ones the longer the period required to transform the forest into the normal state, and the longer the period over which the surplus stock of the older classes would have to be utilised in order to ensure an approximately equal yield during that time.

If $S=$ the stock arailable for exploitation, or which will become available during the $N$ years required to transform the 
forest into the normal state, the annual yield is proportional to $\stackrel{\mathrm{s}}{\mathrm{s}}$.

The greater $\mathbf{N}$ is, i.e., the longer the time (which is dependent on the amount of deficiency in the younger classes) required to change the forest to the normal condition, the smaller will $\frac{8}{5} \mathrm{or}^{\circ}$ the yield become, or, in other words, the fewer the number of trees that can be felled. The easiest and most convenient method at present for ensuring a smaller number of trees being felled is to fix the minimum felling girth at a considerably higher figure than the average girth of the older age classes. It is a rough and ready felling prescription easy to adopt and sufficiently accurate to prevent the forests from being over-exploited. In time, when larger and better trained establishments can be employed for carrying out the important duties of framing "working plans" for the forests, a more exact prescription will be possible.

Meanwhile the great thing to guard against is over-exploitation of the growing stock, or in other words, an encroachment on the wood-producing capital. For the above reasons I strongly recommend the girths suggested by me in that Rule being adopted. Any reduction will be attended by grave risks to the wood-producing capital of the forests.

It is as well to recall here the great danger that attends the exploitation of a forest unless such operations are carefully regulated. It is due to the fact that in removing the wood increment in the form of trees, the wood-producing capital, which also consists of trees, may be removed as well or greatly reduced. The producer and the produce are identical in character, and the accurate determination of how much of the former can be utilized without exceeding the annual quantity of wood produced by the whole forest is beset with great difficulties. The universal tendency is to over-exploit the material produced by forests.

Rule 43.-This should be modified to the effect that the grantors can, without obtaining permission from anybody, fell or cut any trees for their own domestic uses, but not for sale or barter, provided the trees are of the size specified in Rule 25. (b) should stand as it is.

\section{Rule 44.-Sub-rules (1) and (2) should stand.}

Sub-rule (3) should be modified to the effect that the owner has to pay the following fees:-
(a) Upon each mahogany tree
... $30 s$.
(b) Upon each cedar tree ...
... $18 s$.
(c) Upon any other tree ...
... $12 s$.

The concluding paragraph of the principal Rule should remain as it is.

Rule 45 should stand, but fees payable by persons other than the owner should be:-
(a) For each mahogany tree
… 20 .
(b) For each cedar tree ...
... $12 s$.
(c) For every other tree....
$8 s$. 


\section{Miscellaneous.}

Rule 48 should be altered to the effect that such timber as may be required locally for domestic, agricultural, or other like purposes, or for the construction or repair of canoes, ressels, buildings, bridges, tramways, railways, or other like works, but not for purposes of sale, may be felled by the owners of the lands or by any persons authorized by them, provided that fellings for farming purposes are not made within a distance of 100 yards of either bank of a peremnial stream, or on the crests of hills or on their slopes in the immediate vicinity of where such streams have their source, without the consent of the nearest Commissioner or European Forest Officer.

Also add a clause to the effect that trees of any species can be felled, without restrictions as to girth or the payment of fees, on all mining property for purposes of fuel and the ordinary requirements of the mines, but not for sale or barter.

\section{Rules 49 and 50 can stand.}

Rule 51.-This should be altered to the effect that the rules shall apply to all Crown lands and lands leased to the Crown and to native lands, but not to reserves acquired by Government nor to native forest reserves. Also add a clause to the effect that the Governor may, if he thinks fit, exempt any particular locality, by notification in the Gazette, from the application of such rules.

The question as to whether timber concessions already granted and being worked should have the Rules extended to them is a rather difficult one to decide. As the bulk of the most suitable areas have already been taken up, I should adrise their being included under the operation of these Rules, otherwise the best areas and the ones most desirable to protect will be left out in the cold, so to speak, and probably suffer very considerably in consequence, especially if it becomes known that timber Rules are about to be introduced. I would suggest one year's grace being allowed from the date of the Rules coming into force to enable concessionaires to make such arrangements as may be necessary for the altered conditions embodied in the Rules. Meanwhile the ordinance for the protection of immature trees, which is already in force, should be strictly applied to the timber concessions now being exploited.

Some additional Rules for the control and protection of forest produce in transit will be required. They have not been included in the Southern Nigerian Rules because the theft of timber there, except in the Western Province, where the majority of the native councils will have nothing to do with the Rules, is not practised to any serious extent.

The additional Rules should be based on the following, which is an exact copy of part of the Upper Burma Forest Rules (1899).

"1. Marks of two linds only, namely property marks and classification marks, may be impressed by others than forest officers on unconverted or roughly hewn timber. The former denote that the timber belongs or will, after all purchase money or royalties due to Government and the grantors of licences shall 
have been paid, belong to the owner of the mark. The latter denote the origin or the quality of the timber or by whose agency the timber was handled.

“ 2. 'Classification marks' may be impressed only on timber bearing registered property marks. Classification marks may only be impressed upon the authority of the person whose registered property mark has already been impressed on the timber.

"3. All property marks and classification marks and all transfers of such marks shall be registered in the manner hereinafter provided.

“4. Except by the authority of an officer in charge of a forest division, no person shall impress a property mark on any unmarked timber unless he acts under the authority of the owner or licensed extractor of the timber and impresses the registered property mark of such owner or extractor on such timber before it is launched in a floating stream.

" 5. Except by the authority of an officer in charge of a forest division no person shall-

"(a) Mark any timber save with a hammer, the possession of which has been licensed in Form XIX. or XIX. a., and subject to the conditions of that license; or

"(b.) Impress any marik on timber save a mark registered in manner hereinafter provided.

"6. Except by the authority of a person in charge of a forest division no person shall alter or efface any mark on timber and except by like authority no person shall impress a property mark on timber already bearing any mark, unless the timber bears a mark denoting that all money payable to the Gorernment" (to this should be added the word "Grantors" for the Gold Coast Rules) " in respect thereof has been paid and the person acts under the authority of the owner of the timber and uses the registered property mark of such owner.

“7. No person shall possess or carry marking hammers or other implements used for marking timber save under and subject to the conditions of a licence in Form XIX. or XTX. $a$. issued by the officer in charge of a forest division.

"8. No person shall import timber and no person shall for trade purposes move in transit unconverted or rough-hewn timber extracted for trade purposes, unless each log or piece of such timber is distinctly stamped with a registered property mark.

"Exception.-This rule does not apply to bamboos, canes, or firewood in billets or to timber extracted by or on behalf of Government for its use or sale.

"9. Registration of a classification mark or a property mark shall be effected by the owner at a Divisional Forest Office. The forest officer in charge of such office may refuse registration of any mark. After registering any mark the forest officer shall send copies thereof to the offices of other forest divisions where the mark is used.

"10. If the forest officer refuses the registration of any property mark or classification mark he shall record his reasons in 
writing and furnish a roug to the applicant for registration, who may appeal within one month from the date of such refusal to the Conservator of the Circle.

" 11. Whenerer a property mark has been found affixed to any standing tree or to timber which bears traces of the obliteration, alteration, or defacement of some other property mark or has been used to mark or supermark timber in contravention of any of these rules, or whenever the registered owner of a property mark or his agent or serrant has been convicted in a criminal court of making a dishonest use thereof, the divisional forest officer mar cancel the registration of such mark. The forest officer shall record his reasons in writing, and his order shall be subject to appeal to the Conservator of the Circle, if appeal be made within one month from the date of cancellation of such mark.

"12. Whenever any classification mark has been found affixed to any standing tree or to any timber that did not previously bear the property mark to which the classification mark is subsidiary or has been used for obliterating, altering, or defacing other marks, the divisional forest officer may cancel the registration of such mark. He shall record his reasons in writing and his order shall be subject to appeal to the Conservator, if such appeal be made within one month from the date of cancellation of such mark.

"13. Registration and each renewal of registration of a property mark or classification mark shall hold good from the date thereof until the following thirty-first day of ILarch and for the next succeeding two years.

"14. A registration mark mar be borne by one or more hammers. When a mark is borne br several hammers, a number may be borne by each such hammer to denote that it forms one of a series of hammers bearing the same mark, without payment of additional fee. But any modification or alteration in the form or character of a mark shall be separately registered.

*15. Registration effected under any law for the time being in force in Lower Burma shall hold good in the territcries to which the Tpper Burma Forest Regulation, 1S9S, extends as long as it holds good in Lower Burma.

Tote.-Some provision of this sort mas become necessary in the event of different Forest Ordinances being in force in the Gold Coast, Ashanti, and the Northern Territories.

"16. (1) The registration of classification marks is free of fee. Fees for the registration of property marks shall be levied according to the following scale:-

\section{"Property Mark \\ (a) for tenk timber}

Rs.

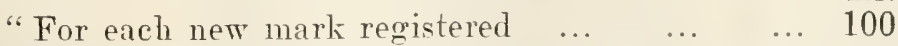

"For renewal of registration of a mark before it has lapsed or within three months after it has lapsed 
For renewal of registration of a mark after the expiration of three months firom the date on which the registration lapsed $\quad \ldots \quad \ldots$

$\begin{array}{llllll}\text { “For transfer of a mark } & \ldots & \ldots & \ldots & \ldots & 10\end{array}$

Rs.

" (b) for other timber

" For each mark registered or transferred

" For renewal of registration of a mark before it has lapsed

"For renewal of registration of a mark after it has lapsed

‥ $\quad \ldots \quad \ldots \quad \ldots$

". (2) The fee prescribed in sub-section (1) of this rule shall ordinarily be levied before the mark is registered, but the divisional forest officer may, for reasons to be recorded, permit the fee to be paid in instalments. In the latter case the registration of the mark shall cease to hold good if default is made in any of the instalments. 'The registration of marks used by Government contractors shall be free.

Note.-Fifteen rupees are equivalent to twenty shillings, or $\mathfrak{f}^{\prime} 1$.

"1i. Timber of which the ownership is not indicated by a registered property mark shall not be entitled to a pass under Rule :35."

The above quoted Rule is as follows:-

“(1) No per'son shall move timber in transit without a pass from the deputy commissioner of the district or forest officer of the forest division in which the timber is, or from an officer empowered by such deputy commissioner or forest officer in that behalf, or otherwise than in accordance with the conditions of snch prass. Provided that this rule shall not apply to-

* (a) Bamboos or firewood in billets.

"(b) Timber collected under a licence granted in accordance with Rule i2.

"(2) The pass shall be in the form of Appendix XVI.

" (3) Such pass shall be producerd on the demand of any forest officer or police officer.

" (4) Timber for which such a pass is not produced may be detained by any forest officer or police officer."

Tnder the Burma Rules fees are levied on timber for which such passes are given, but I do not recommend this being done on the Gold Coast, for the present at all events.

This pass will usually be given when the timber is marked with the Government Pass mark (denoting that all fees and roralties parable on the timber have been paid), ride Rule 20 (4) of the Sonthern Nigeria Timber Rules.

In Bnrma timber stealing has been reduced to a fine art, and the above quoted Rules have been found sufficient to meet all roquirements for protecting timber against theft.

Similar rules should, I think, be enforced on the Gold Coast, especially in the Axim distriet, where, I understand, stealing of such produce is rery prevalent. 
In the above Rules the divisional forest officer corresponds to a Provincial forest officer of Southern Nigeria, and deputy commissioner to a district commissioner in our West African Colonies and Protectorates.

Additional Rules will be required:-

1. To regulate the size of rafts and the minimum number of men in charge of them. This will depend on local conditions and the presence or absence of dredgers and launches in the water-ways.

2. To provide for the establishment of timber depots at-

(a.) The mouth of the Ankobra River;

(b.) The terminus of the railway at Sekondi,

for the purpose of examining all timber before it is exported to Enrope.

The particular spots at which the depots are to be formed should be left till a forest department has been formed on the Gold Coast.

The Customs authorities will have to see that no logs are shipped for Europe that do not bear the Government Pass mark.

Timber imported from Europe might be exempted from the rules relating to hammer marks and Passes.

Rule 14 of the Southern Nigerian Timber Rules will require alteration in accordance with the above quoted rules regarding the registration of hammer marks.

"Classification marks," I may explain, are marks used by timber merchants and others for their own private information with a view to indicating from what forest, stream, or contractor, \&c., the timber is procured.

3. A rule to the effect that-

No person shall convert, cut, burn, or conceal any timber in respect of which any money is parable to Government or the native communities.

4. A rule to the effect that-

No person shall establish or convert timber at a saw-pit or saw-mill within a distance of 1 mile from any river used for floating timber in rafts or of 10 miles of any railway, save under and subject to the conditions of a licence in the form given below, granted by the district commissioner or forest officer of a district or by an officer empowered by either of them.

The licence form should be as follows:-

Book number

Licence number

Licence to establish and convert timber at a sawpit or sawmill has been granted under Rule of the Timber Rules to (name of person) of (residence) for a period of (months) under the following conditions from the (date) to the (date).

(1) That the sawpit is established within the following boundaries

(2) That this licence is not transferable and must he in the possession of the person to whom it was granted or of his agent, when such person or his agent is using the sawpit. 
Breach of any of the above conditions will render the holder liable to the forfeiture of the licence as well as the punishment prescribod in the Timber linles.

'The (date)

Signature and designation of

Officer granting the licence.

The licence forms for the registration of property marks and classification marks should be as below:-
Book number
Licence number

\section{Licence to possess and carry a marking hammer.}

\section{(Name) . . . . of (residence)}

is permitted under Rule of the 'Timber Rules to possess, carry, and use within the under-mentioned limits the marking hammer or implement bearing the impression shown on the reverse of this licence and subject to the conditions noted below. 'The limits above referred to are . . . (the district, forest, stream, de., as the case may be, or the area covered by the timber licence).

The time for which permission to use the hammer-mark hereby licensed is from

The conditions subject to which this licence is granted are:-

(1) That the licensee shall at all times have the licence in his possession when using the hammer.

(2) That the licence is not transferable, but the licensee may make over the licence and the hammer to which it refers temporarily to any person in his own employ or in the same employ as himself, provided that the name of the transferee and the date of transfer are endorsed on the licence. Breach of any of the conditions of this licence will render the licence liable to forfeiture and the holder thereof to the punishment prescribed in the 'T'imber Rules.

Date

\section{Provincial Forest Officer, Province.}

\section{Book number \\ Licence number}

\section{Licence to use a Classification Mark.}

(To be issued only to owners of registered property marks or their servants and only for mahogany and cedar timber.)

Name

is permitted under Rule of the Timber Rules to possess, carry, and usc within the under-mentioned limits the classification hammer mark or implement bearing the device shown on the reverse of this licence from the . . (date) to the . . . (date), subject to the conditions noted 
- (1) That the mark shall only be impressed on mahogany and cedar logs already bearing the registered property mark.

(2) That the person using the hammer shall carry the licence.

(3) That the licence is not permanently transferable, but may be temporarily transferred to a servant or fellow-servant of the licensee, if the transferee's name and date of transfer are endorsed on the licence.

The limits referred to are

$$
\text { (District, forest, \&c.). }
$$

The time for which permission to use the hammer mark hereby licensed is granted is from

Date

Provincial Forest Officer,

Province.

The Timber Remocal L'ass should be in the following form :Book number Pass number

Pass to remove timber has been granted under kule of the Timber Rules to

(1) Owner's name;

(2) Destination ;

(3) Kind of timber;

(4) Hammer mark;

(5) Amount of timber';

(6) Place at which Pass must be presented ('Timber depôt);

(i) Date of expiry.

Any one noving timber without a pass in this form is liable to a fine of $£ \quad$ or months' imprisonment.

Date

Signature and designation of Officer granting the pass.

Tote.-The depôts to which timber has to be taken should be notified from time to time in the Official Gazette. They should be placed at the termini of the various lines of export unless a large local trade between one district and another springs up, in which case they should be established at the most convenient places on these local lines.

Lastly, as regards the question of drift timber, I cannot do better than quote in extenso the Burma Forest Rules on this subject. They should be closely followed in any adaptations made for the Gold Coast:-

"46. Timber falling under any of the following descriptions, namely:-

"(a.) Timber found adrift, heached, stranded, or sunk:

"(b.) Timber bearing marks that have not been registered under rules made under Section 43 ;

"(c.) Timber which has been super-marked or on which marks have been obliteraterl, altered, or defirced by fire or otherwise; and 
"(d.) In such areas as the Local Government directs, all unmarked timber;

" shall be deemed to the the property of the Government unless and until any person establishes his rights thereto, as provided in this chapter." (See quotations of sections following this one.)

"(2.) Such timber may be collected by any forest officer or other person entitled to collect the same, and may be brought to such stations as a forest officer, specially empowered in this behalf, may from time to time notify as stations for the reception of drift timber.

“(3.) The Local Government may, by notification in the local (1)icial Gazette, exempt any class of timber from the provisions of this section.

"47.-(1.) Public notice will from time to time, as occasion may require, be given by a forest officer, specially empowered in this behalf, of timber collected under the last foregoing section.

"(2.) Such notice shall contain a description of the timber and shall require any person claiming the same to present to such officer, within a period not less (? more) than one month from the date on which such notice is given, a written statement of such claim.

"48.-(1.) When any such statement is presented as aforesaid, the forest officer may, after making such enquiry as he thinks fit, either reject the claim, after recording his reasons for doing so, or deliver the timber to the claimant.

"(2.) If such timber is claimed by more than one person, the forest officer may either deliver the same to any such person whom he deems entitled thereto, or may refer the claimants to the Civil Court, and retain the timber pending the receipt of an order from the Court for its disposal.

“(3.) Any person whose claim has been rejected under this section may, within six months from the date of such rejection, institute a suit to recover possession of the timber claimed by him, but no person shall recover any compensation against the Government or against any forest officer on account of such rejection, or the detention or removal of any timber, or the delivery thereof to any person under this section.

"(4.) No such timber will be subject to the process of any Civil Court until it has been delivered or until a suit brought under this section has been decided.

" (5.) Every suit instituted under this section shall be subject to the provisions of Section 424 of the Code of Civil Procedure.

"Provided that the notice required by the said prorision shall l,e given within three months from the date of the rejection, under Sub-section (1), of the intending plaintiff's claim.

"49. Where no statement is presented in the manner and within the period prescribed by notice issued under Section 47, or where such statement haring been so presented and the claim rejected the claimant omits to institute a suit to recover posses- 
sion of such timber within the further period mentioned in Sectiou 48, the ownership of such timber shall vest in the Government free from all incumbrances or, when such timber lias been delivered to another person under Section 48, in such person free from all incumbrances not created by him.

“50. To person shall be entitled to recover possession of any timber collected or delivered as aforesaid until such sum as may be due for salving, collecting, moving, storing, and disposing of the timber has been paid by him to the forest officer or other person entitled to receive the sum.

.51.-(1.) The local Government may make rules to regulate the following matters, namely:-

"( $($.) The salving, collection, and disposal of all timber mentioned in Section 46 ;

*(b.) 'The use and registration of boats used in salving and collecting timber;

"(c.) The amount to be paid for salving and collecting, moving, storing, and disposing of such timber; and

" $(d$.$) 'The use and registration of hammers and other imple-$ ments to be used for marking such timber.

“(2.) The Local Government may by rule under this section attach to the breach of any rule under this section any punishment not exceeding imprisonment for a term which may extend to six nonthis, or fine which may extend to five hundred rupees, ol both."

The above-quoted sections belong to the Upper Burna Forest Regulations: which rorrespond to the forest ordinances of Southern Nigeria, and as the latter in Sections 20 (11) and $20(12)$ does give the Governor in Council the power to make rules to regulate the "transport of timber by land and water," and the "salving and disposal of drift timber," these sections of the Lpper Burma forest regulations can be taken as a basis on which to frame the rules that the Southern Nigerian ordinance provides for. The Upper Burma regnlations have merely expressed in more detail in the regulations itself what would ordinarily be expressed in rules framed under the principal ordinances of our Colonies.

'The Upper Burma forest mles relating to the salving, collection, and disposal of drift, strander, or other timber are:-

"Rule 68. In Rules 69 to $\tilde{i} 4$, the following words have the following meaning:-

"Log-means a piece of timber which is 4 feet 6 inches or" more in mean girth (i.e., the girth taken at the middle of length of the $\log$ ).

" $Y$ atthit-means a piece of timber 15 feet or more in length and having a mean girth of 2 feet or more but less than 4 feet 6 in shes.

"Piece-means a piece of timber that is neither a $\log$ nor a yatthit.

" 69. All timber found adrift, beached, stranded, or sunk may be salved by any person, and shall either be secured on a bank or, 
at the discretion of the salver, be taken to the next station down stream notified under Section 46 of the Upper Burma Forest Regulations, 189S, as a station for the reception of drift timber.

" 0 . (1) The salver shall be entitled to the following banksalvage for the securing of the timber:-

\begin{tabular}{ll|r|r|rr|r}
\hline & & Per log. & Per yatthit. & Per piece. \\
\hline & & & & & \\
\hline
\end{tabular}

and in addition thereto a payment at such rates as may from time to time be prescribed by the Conservator for delivery of timber at stations notified as aforesaid.

“(2.) When rafts or compartusents of a raft which hare been abandoned by raftsmen are salved only half the bank-salvage shall be payable." (Note-One anna = one penny.)

"71. The salver shall not deliver any timber salved by him to any person but a forest officer or a person entitled under a licence to collect such timber, and may refuse such delivery until the full payment to which he is entitled under the last foregoing rule has been tendered.

“72. (1.) No person other than a forest officer shall collect salved timber without a licence or otherwise than in accordance with the conditions of the licence.

"(2.) Such licence shall be granted by the officer in charge of the forest division, and shall be in the form of Ippendix XX. to these rules.

"73. For all salved timber delivered to owners from stations notified as aforesaid the following fees shall be paid in addition to the salvage charges prescribed in and under Rule $\% 0$.

\begin{tabular}{|c|c|c|c|c|c|}
\hline- & & & Per log. & Per yatthit. & Per piece. \\
\hline $\begin{array}{l}\text { Teak ... } \\
\text { Other timber }\end{array}$ & $\begin{array}{l}\cdots \\
\cdots\end{array}$ & $\cdots$ & $\begin{array}{rrr}\text { Rs. } & \text { a. } & \text { p. } \\
1 & 8 & 0 \\
0 & 8 & 0\end{array}$ & $\begin{array}{rrr}\text { Rs. } & \text { a. } & \text { p. } \\
0 & 12 & 0 \\
0 & 4 & 0\end{array}$ & $\begin{array}{rrr}\text { Rs. } & \text { a. } & \text { p. } \\
0 & 6 & 0 \\
0 & 2 & 0\end{array}$ \\
\hline
\end{tabular}

“74. On timber stored or left at a station notified for the reception of drift timber for more than one month after the timber has been delivered by a forest ofticer to a claimant under Section 45 of the regulations, a fee of two annas per log shall he levied for each month or fraction of a month during which the log remains at the station. Provided that no fee shall be leviable until after the expiry of fourteen days from the date of issue of notice in writing to the owner or other person interested in the timber, requiring him to remore it. The period of fourteen days shall 
count trom the date of notice whether the notice reaches the owner or person interested or not. It shall be the duty of the owner or person interested in timber stored or left at a drift timber station properly to secure it and keep it in safety, no responsibility in respect thereto being undertaken by the Iorest officer in charge or by Gorermment.'

Such are the provisions that it has been found necessary to make in Burma for the protection of forest produce in transit. Similar enactments, modified to suit local requirements, should be made in the timber rules for the Gold Coast. The spirit and essential points of the above quoted rules and regulations should, however, be preserved in the local rules, as they have been based on a long experience of timber exploitation and the dangers that have to be guarded against in a country where the conditions are somewhat similar to those prevailing in West Africa.

It remains now to mention that stations for the reception of drift timber will have to be notified from time to time in the ()fficial Gazette: a few of them along the course of the Ankobra River and one at Sekondi should suffice for the present. In the event of the forests in the lower Tano drainage being much exploited a station will have to be formed at the mouth of the canal leating from that river to Half Assini.

The licence to collect sulvel timber should be in the following form:-

Book number

Licence number

incence to collect salved timber under Rule of the 'Timber Rules has been granted to of who is permitted to pay bank-salvage and collect logrs bearing the marks noted below within the undier-mentioned limits from the (date) to the (dute) both days inclusive, subject to the following conditions:-

(1.) That bank-salvage shall be paid at the rate fixed by Rule of the Timber Rules.

(2.) That no timber bearing marks other than those noted below shall be collected.

(3.) 'That only the person in whose name the licence is issued shall collect timber under the licence. and that at the time of collection the liceuce shall be in his possession.

(4.) That the timber shall be brought to and reported at one other of the following places. mamely :-

The limits above referred to are-

The marks above referred to are-

Breach of any of the conditions of this licence will render the licence liable to forfeiture and the holder thereof to the punishment prescribed in the following rules.

Date.

Signature of officer granting the licence. 
Lastly, when, in accordance with Section 49 of the Upper Burna Forest Regulations (quoted above), the ownership of cer. tain timber vests in the Goverument, this ownership should refer to the native rommunities from whose lands the timber in question was extracted. If such ownership cannot be ascertained, then the timber should become the property of the Gold Coast Govermment.

As regards timber rules for the Northern Territories, I think that a few simple rules to the following effect will suffice for the present.

Rule 1.-That no trees of the species specified below and of less girth than that provided for in this rule shall be felled by any person without the permission of a District Commissioner or Forest Officer.

The speries and their minimum felling girths measured at a height of 4 feet 6 inches from the ground are:-

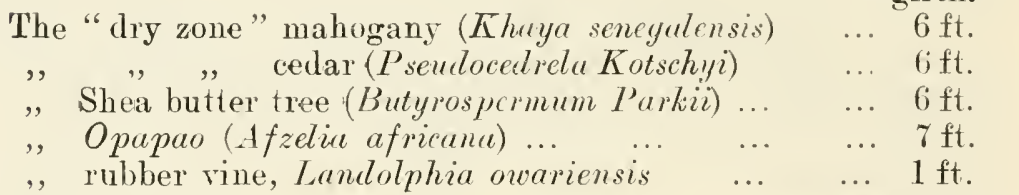

$\begin{gathered}\text { Minimum } \\ \text { girth. } \\ \ldots \quad 6 \mathrm{ft} . \\ \ldots \quad 6 \mathrm{ft} . \\ \ldots \quad 6 \mathrm{ft} . \\ \ldots \quad 7 \mathrm{ft} . \\ \ldots \quad 1 \mathrm{ft} .\end{gathered}$

Rule 2.-That no person shall "take " for the purpose of trade or barter any timber except in accorlance with the conditions contained in the licence form appended to these rules.

Rule 3.-That the forests are not to be cleared for farming purposes within 100 yar!s of either bank of a perennial stream, except with the permission of the District Commissioner or Forest Officer. The same rule to apply to regetation growing round the sources of streams and aloug the summits and crests of the hills.

The licence form should be somewhat as follows:-

$$
\text { Trade Licence to take Timber. }
$$

\section{Book number Licence number}

Licence to fell the trees specified on the reverse and to remore the timber to (locality where it will be sold) is granted under Rule 2 of the Northern Territories Timber Rules for months from this date to (person) of (residence) subject to the following conditions:-

(1.) That only trees of the number, spccies, and size specified on the reverse are felled.

(2.) That no trees are felled in such a manner as to cause injury to any trees of the species mentioned in Rule 1 of these rules.

(3.) That all branch pieces and other débris left after a tree has been felled shall be removed to a distance of not less than 20 feet from any species of tree mentioned in Rule 1. 
(4.) That no trees are felled or mored after the time for which this licence is granted shall have elapsed.

(5.) That royalty at the under-mentioned rates shall be paid on the timber, and that the timber shall not be removed, converted, or utilized until such royalty has been paid in full.

(6.) 'Ihat if all dues on the timber are not paid on or before the day of , 19 , the timber mentioned will lapse to Govermment.

(7.) That unless the licence be obtained expressly for such purposes as providing house or bridge posts or the like, none of the following trees, the "dry zome", mahogany (Khaya senegalensis), the "dry zone" - cedar (Pseudocedrela Kotschyi), the Opapao (Afzelia africana) shall be felled of less than 6 feet girth in the case of the two former species, and 7 feet in the case of the latter, at a height of 4 feet 6 inches from the ground.

(8.) That no shea butter tree is felled.

(9.) That the licensee shall mark all timber felled under the authority of this licence with a hammer mark duly registered at the office of the District Commissioner or Forest Officer.

Breach of the above conditions will render the liolder liable to forfeiture of his licence, and confiscation of the timber, as well as to the punishment prescribed in the Timber Rules.

\section{(Reverse of Licence.)}

Tumber and Girths of Trees to be felled.

\begin{tabular}{c|c|c|c} 
No. & Species. & $\begin{array}{c}\text { Girth below which } \\
\text { trees may not be } \\
\text { felled. }\end{array}$ & $\begin{array}{c}\text { Mark of } \\
\text { licensee's registered } \\
\text { hammer. }\end{array}$ \\
\hline & & & \\
\hline
\end{tabular}

Limits within which trees may be felled or boundaries of area).

(name of forest

Dated the

District Commissioner or

Forest Officer,

District. 
Account of T'imber brought out.

\begin{tabular}{c|c|c|c|c}
\hline Date & Logs. & Cubic feet. & Remarks. & $\begin{array}{c}\text { Initials of } \\
\text { officer }\end{array}$ \\
\hline & & & & \\
\hline
\end{tabular}

Rule 4.-The royalties paid on timber extracted under a licence for trade or barter shall be distributed as follows by the District Commissioner: -

Three-fifths shall be paid into the local Treasury.

Two-fifths to the native communities on whose lands the timber is cut.

Rule 5.- Native communities in receipt of timber royalties shall help the District Commissioner to enforce the conditions under which a licence to trade in timber is granted.

some rules providing for penalties to breaches of the above should be added.

The protection of the trees specified in Rule 1 will cause little or no hardship to the native farmers in the open savannals in which they grow, and with the exception of Afzelia africana they cast very little shade.

The protection of the belts of regetation found growing along the banks of streams is of very great importance in the dry zone, and the same remark applies to forest growing round the sources of the streams, on the tops of ridges, and along the crests of hills.

It is verr probable that other trees may have to be eventually put under the protected list when more is known about the forest regetation of the hinterland.

\section{General considerations regarding Timber Rules.}

It will be seen, from the proposals put forth regarding the legislation that is considered necessary in the form of rules, that a certain amount of protection has been afforded to forest areas in general and their exploitation under proper restrictions prorided for. Such measures are, however, of a tentative nature and are only necessary till such a time when the best forests and a sufficient extent of wooded land has been placed under the intensice protection aftorled by reservation. Reserves are the permanent estates from which the demands for forest-produce will have to be met in the future, and they therefore require different treatment from the generally protected areas, which latter are only protected in order to give sufficient time within which to complete the selection and reservation of the forests that it is considered necessiny to manage solely as estates for the supply of forest produce.

The procerlure involved in reservation is a long one, and many years must lapse before enough wooded lands have been taken 
up for that purpose. Neanwhile, unless a cortain amount of protection is afforder to the forests in general, there is risk of thein being destroved or sererely damaged hefore the choice of areas that it is considered desirable to reserve has been completed. As a measure suited to the uncertainty that must exist for very many years whether permanent forests will be required in some areas, or whether it will not be hetter to give up such areas to cultivation and agriculture in general, this type of limited protection is invaluable.

When the reservation of the quantity of wooded land considered necessary for meeting all the demands for forest produce likely to be made in the future has been completed, and when the permanent existence of a sufficient extent of forest has been ensured with a view to protecting and improving the climatic factors of the country, then and then only will it be advisable to remove all restrictions from the unreserved areas. It is difficult to estimate what percentage of the forest lands should be reserved, because future requirements camnot be accurately allowed for. In India about 39 per cent. of the area of forest lands has been reserved and the area brought under this treatment is still increasing in extent almost every year.

\section{Rules relating to Forest Reserves.}

We now come to the consideration of the orders and rules necessary for the regulation and management of forest reserves, which expression includes the native forest reserves provided for in the Southern Nigerian Urdinance as amended by me for the purposes of the Gold Coast.

The Southern Nigeria Rules relating to forest reseres consist of :-

A. Prohibitions.

3. Rules and regulations, and

An appendix containing licence forms for use in reserved forests.

The corresponding reserved forest rules for the Gold Coast should be identical with those enacted for Southern Nigeria, and they will, in that form, be found to meet all the requirements of the case.

As mentioned before, reserves should be looked upon as estates that are to be protected and managed solely nith a riew to supplying forest produce hoth for local use and, if necessary, for export, as well as for the purpose of ensuring that beneficial action on the climatic factors associated with the presence of large masses of forest regetation.

The necessity for placing such areas on a proper legal footing. by defining their boundaries (as pieces of property) and the rights to be exercised in them, \&c., has already beeu explained, and it is only necessary now to remark that unless this legal protection has been properly secured it is useless to anticipate any good results from a system of forest conservancy in which an essential guarantee of that sort is manting. It is not wortl while going to the expense of introbucing measures for the treatment and 
exploitation of the forest, such management being necessarily based on the assumption that it can be exercised without hostile interference for at least several generations, if not centuries, when the very existence of the forest as such is not guaranteed for a sufficient length of time to realize the object of the management. It is sheer loss of time and money to the State. On the other hand, it is absolutely certain that without the legal protection afforded by roservation, the forests will in time cease to exist. No property of this sort regarding which the rights of ownership and prescription have not been legally defined, limited, and regulated, can exist for very long, more particularly in countries like our West African Colonies and Protectorates. Whatever measures may be adopted for the general protection afforded to the forests under enactments such as the Timber Rules, it will be found in course of time that they are quite insufficient to meet the demands of forest conservancy. The latter, without the power to legally constitute reserved forests, is a mere ghost and caricature of what it should be.

\section{PART II.}

13.-Suggestions as to the Forest Policy and Administration to be adopted on the Gold Coast.

Having lealt with the question of legislation, the next points to consider are the means by which the provisions of the Ordinance, Orders, Rules, \&c., should be put into practice, and the general policy to be followed in regard to Forest Conservancy and Administration on the Gold Coast.

These matters can be most conveniently dealt with under the following heads :- -

A. Establishments necessary for carrying out the provisions of the Forest Laws and for the systematic protection and management of the forests.

B. The selection of areas for reservation.

C. The collection of data for the preparation of "Working Plans" and the methods under which the forests should be managed.

D. The botanical survey of the forests.

E. The training of the subordinate staff.

F. Forest plantations.

G. The inspection and supervision of timber concessions and licensed areas.

H. General forest policy.

Taking these in the order mentioned, as regards

\section{A.-Forest Establishments.}

The Forest Administration of the Gold Coast should be carried out by means of the staff, European and native, shown below:.- 


\section{European Staff' (superior Forest Service) 'This should consist of :-}

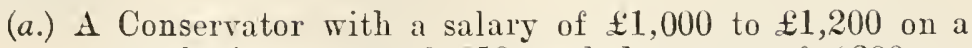
yearly increment of $\$ 50$, and duty pay of $₫ 200$ per annum.

(b.) A Deputy Conservator on a salary of $£$ r00 to $₫ 900$, with a yearly increment of $₫ 50$ and duty pay of $₫ 140$ a year.

(c.) Senior Assistant Conservators (1st grade) with salaries of $₫ 450$ to $₫ 650$ per annum, a yearly increment of $£ 25$, and duty pay at the rate of $£ 90$ per annum.

(d.) Junior Assistant Conservators (2nd grade) with salaries

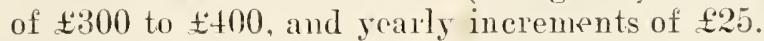

The Deputy Conservator will act for the Conservator when the latter is absent on leave, and will be his second in command.

'The Senior Assistants will ordinarily hold charge of the larger Administrative Divisions, such as the Gold Coast, Ashanti, and the Northern Territories.

The Junior Assistants will hold charge of groups of Districts corresponding to the Political Divisions known as Provinces.

The Conservator, Deputy Conservator, and Senior Assistants should, as far as possible, be recruited from professionally trained men who have already had some experience of actual executive and administrative mork.

The Junior Assistants should be recruited from amongst men who have just passed through University or other similar courses of instruction in Forestry.

In proposing the above salaries, I have been guided mainly by the urgent necessity that exists for procuring trained men to fill the appointments, and the lowest existing market rates at which good men with those qualifications can be obtained. When the peculiar nature of the duties involved, the special training necessary, and the opportunities that exist for careless or improper treatment (the effects of which very often cannot be ascertained till generations have passed, and the officers concerned also gone) to seriously damage the forests are recalled, I think it will be admitted that the scale of salary proposed above is none too liberal.

Applications should be made to the India Office to induce men from the Indian Imperial and Provincial Forest Services to accept the higher-paid appointments. If necessary the appointments may be offered for three years to begin with, with the option of making them permanent at the end of that period by mutual consent. This may induce persons who are loath to leave India permanently for residence in unhealthy climates like that of West Africa to defer their decisions on this matter till they have artually had experience of the climate on the Coast and their reactions towards it. I am confident that once it is generally known in India that the climate of the West Coast of Africa is not quite so black as it is painted, and that the general 
conditions of life out there for Europeans have vastly improved of late rean's, many persons will be willing to risk it, at all events for three years to begin with, if by doing so they can better their prospects to any appreciable extent.

In this connection, it will be useful for purposes of comparison to give a list of the Indian Forest Establishment, so far as the Upper Comptrolling Staff is concerned.

It consists of

One Inspector-General, on Rs. 2,650 per mensem or $₫ 2,120$ per annum.

Two Chief Conservators, each on Rs. 2,150 per mensem or $£ 1, \pi 20$ per anmum.

Nineteen Conservators-

Six of 1st grade, on Rs. 1.900 per mensem or $£ 1,520$ per annum.

Seven of 2 nd grade, on Rs. 1,700 per mensem or $£ 1,360$ per annum.

Six of 3rd grade, on $\mathrm{Rs}$. 1,500 per mensem or $£ 1,200$ per annum.

136 Deputy Conservators.

i2 Assistant Conservators.

9 Foreign Service (four temporary).

One Assistant Inspector-General.

Five Ufficers at the Imperial Forest College and Research Institute, Dehra-Dun (who each draw in addition to their pay a special allowance of $\mathrm{Rs} .150$ a month).

Assistant Conservator's start on a. salary of $R_{s}$. 380 per mensem ( $₫ 304$ per annum), which rises by annual increments of Rs. 40 per mensem ( $£ 32$ per annum) to Rs. 700 a month or $£ 560$ a year, and after that (they then become Deputy Conservators) by increments of Rs. 50 a month ( $\& 40$ per anmum) to Rs. 1,250 per mensem or $\mathfrak{f 1 , 0 0 0}$ a year in the twenticth year of service.

The salaries of the Provincial Staff are on a much lower scale, though its members are for practical purposes equaliy rapable; it is from this branch that I anticipate applications for transfer to West Africa.

The promotion is thus continuous up to the twentieth year of service, and a first grade Deputy Conservator then draws a pensionable salary of $\mathbb{1} 1,000$ a year.

An officer can retire on pension after 25 years' service.

As regards the number of Assistant Conservators that will be required for the Gold Coast Establishment, the following staft should be gradually worked up to:-

One senior Assistant Conservator for each of the three administrative divisions, namely, the Gold Coast. Ashanti, and the Northern Territories, together with an addition of two more to act for the former when they are absent on leave.

Of the junior Assistants, three will be required for the Gold Coast, three for Ashanti, and two for the Northern Territories. 
This will bring the Forest Establishment up to the following strength :-

$\begin{array}{lcccc}\text { One Conservator } & \ldots & \ldots & \ldots & 1,000-50-1,200 \\ \text { Duty pay } & \ldots & \ldots & \ldots & 200 \\ \text { One Deputy Conservator } & \ldots & \ldots & 700-50-900 \\ \text { Duty pay } & \ldots & \ldots & \ldots & 140 \\ \text { Five Senior Assistant Conservators... } & 450-25-650 \\ \text { Duty pay } & \ldots & \ldots & \ldots & 90 \\ \text { Eight Junior Assistant Conservators } & 300-25-400\end{array}$

The cost of this Establishment will for the first year amount to $\mathfrak{i} \tau, 140$, a sum that will be more than covered by forest revenue.

2. Native Staff (Subordinate Forest Service). This should consist of :-

Forest Rangers.

i. Forest Rangers of the first gralle, with salaries of E72 per annum.

ii. Forest Rangers of the second grade, or Deputy

Foresters. Rangers, on salaries of $₫ 60$ per annum.

i. Foresters, first grade, on $\mathfrak{E} 48$ per annum.

ii. Foresters, second grade, on $£ 36$ per annum.

Forest Guards.

i. Forest Guards, first grade, on $£ 24$ per annum.

ii. Forest Guards, second grade, on $£ 18$ per annum.

The actual number of men required cannot be estimated for with any accuracy at present, and the matter can be deferred till the European Staff has been appointed. An annual expenditure of $£ 1,500$ on the Native Staff should provide for all the men that will be required during the first few years.

\section{B.-Selection of Areas for Reservation.}

The exploration of the forest areas, with a view to selecting the best for Reserves, will form the most important duty of the European Staff. As the process is one that takes a long time to complete, it should be started as soon as ever a department has been established; it is of the utmost importance that as much as possible of the richest forests should be reserved before they have been damaged by the native farmers or over-exploited for the export trade. Every dry season the forests should be systematically explored, and proposals submitted for the reservation of the best ones, and this selection should be left to the more experienced Senior Assistant Conservators.

Special attention should be paid first to areas covered with high forest that shows few, if any, signs of having been modified by the action of man during the past. Of such areas, those should be selected for reservation that contain a fair proportion of any or all of the following species of valuable plants:-

$\left(a^{1}\right.$.) Mahoganies, of the genus Khaya.

$\left(b^{1}\right.$.) Cedars, of the genus Pscudocedrela.

$\left(c^{1}\right.$.) Cedars, of the genus Lovoa. 
(d $d^{1}$ ) The Odonm or Iroko (Chlorophora excelsa).

(e $e^{1}$ ) The Balin (Kimusops / jace).

( $f^{1}$ ) The $K$ aku (species of Lophira).

$\left(g^{1}.\right)$ The Kolioti (Pynaertia ealaensis).

$\left(h^{1}\right.$.) 'The $N^{\prime}$ yanliom. (Heritiera utitis).

(i.) The silk rubber tree (Funtumia elastica).

$\left(j^{1}\right.$.) The rubber vines, Landolphia onariensis and $L$. Thompsonii.

$\left(k^{1}\right.$.) The gum copal trees (species of Cyanothyrsus).

$\left(l^{1}\right.$.) The oil-hean tree (Pentarletlira macrophylla).

( $\mathrm{m}^{1}$.) Awama (Ricinodendron africanus).

$\left(n^{1}.\right)$ Trees the wood of which is used for making shingles, such as the Offram (Terminalia scutifera) and the Emril, another species of Terminalia;

and, finally, any other species of plant that furnishes raluable or durable timber or other produce of economic value.

It will generally be found that a large proportion of the abovementioned plants are to be met with in one and the same forest, so that its reservation will afford protection at the same time to a great many of the species that it is desirable to conserve.

When selecting areas for reservation, information regarding the sylvicultural peculiarities of the more important species should be carefully collected and recorded.

The time of flowering and seeding, whether annual or occurring at intervals of several years, the time the fruit remains on the tree before it falls (in some species the fruit remains on the tree for two or three years), should be noted, as well as:--

(i.) The kind of soil that suits each species best.

(ii.) In hilly country the aspect, i.e., the slope of the ground, whether north, south, east, or west, on which the species thrives.

(iii.) The relation of the more important species to the other plants in the forest; whether they are being dominated or likely to be suppressed by others, and the state of their natural regeneration.

(iv.) Whether the species is a light-demander or can stand dense shade.

(r.) Whether it is evergreen or becomes defoliated at periodical intervals, and so on.

The observations indicated above will take years to carry out thoroughly, but they should never, on account of their importance, be lost sight of, and every endeavour should be made to keep continuous reconds from year to rear on these points.

When selecting forests for reservation, it will be found that comparatively few tracts are covered with so-called primeral or virgin forest; the majority of forests on the Gold Coast and in Ashanti consist of secondary irregular growth that has sprung up on areas previously cleared for farms by the natives. In places, such forests have, since they re-occupied the abandoned farms, been left untouched for such a loug time that a sufficient interval has elapsed for the trees composing them to have grown into large trees of rery nearly as good growth as the original 
ones that were felled. Such forests should be selected in preference to those of younger age, commonly met with close to the larger native towns and villages.

Again, forests situated within a reasonable distance of "floating" streams (streams capable of floating out large logs), should be chosen in preference to those at present inaccessible to exploitation, unless, of course, the reservation is made with the object of protective belts of forest, with a view to the latter exercising its functions of preserving or improving the factors of the locality.

The strstem of farming in rogue with the natives is such that large tracts of forest-covered land are necessary for the successful carrying ont of these operations; very much more land, in fact, than would be sufficient in the case of permanent cultivation. It is, therefore, necessary that the forest officer should, when submitting proposals for reservation, first ascertain whether sufficient forest or scrub-covered land will still be available to the natives for farming purposes after the reservation has taken place. He should make enquiries regarding the size of the native villages and their rate of increase of population; the area required annually by each for farming purposes; the length of the farming rotation; the number of crops raised on the newlycleared farms before they are allowed to lie fallow, and the nature of the crops gromn.

Some of these points, especially the rate of increase of population, can be adequately dealt with only in the course of a proper anthropological surver; and if any such work is undertaken, it is desirable that the needs of the Forest Department should be kept in view when the scheme for such a survey is prepared. Information as to native forest laws and land laws in general should also be collected and put at the disposal of the Forest Department.

Details of this description should always accompany the reserve proposals.

All areas that are found sufficiently rich for reservation should be surveyed with the compass and rope, or the plane-table; more especially the boundaries of the reserves. which should consist, as far as possible, of easily identified features, such as ridges of hills (water-partings), the course of streams, roads, and paths. Thilst these traverses are being made, the "valuation surveys," referred to under " (C) The Collection of Data for the Preparation of "Torking Plans," in this chapter, should be carried out in conjunction with them. The valuation surveys will further help to fill in the interior details of the sketch map forwarded with the proposals for reservation. Such maps should have marked on them the positions of all villages that are likely to be directly affected by the reservation of the area concerned.

Rough surveys made with the aid of the compass and pacing, timing, \&c., should also be carried out along forest roads and paths not already shown on the maps of the Colony and Protectorates. The field sheets of such surveys ought to be forwarded to the Superintendent of Surveys, with a view to their being utilized in the preparation of later editions of the maps. 


\section{C.-The Collection of Data for the Preparation of Working Plans.}

This very important work should be undertaken concurrently with the exploration and selection of areas for reservation. In the early stages of forest conservancy in tropical West Africa, it will not be possible to undertake any refined and costly measures of this sort, but simple and approximate methods of the nature indicated below should invariably be adopted with a view to supplying some information regarding the actual condition of the growing stock in the forests, and for the purpose of framing simple and safe prescriptions for their exploitation till such a time as more detailed and accurate systems become possible. Reserves should invariably be exploited under some such simple prescription, that limits the fellings to a definite proportion of the mature timber they contain. For example, a prescription that limits the fellings during a specified period to one-third, say, of the number of mature trees standing in the reserve is both simple to understand and to apply. It merely means that ont of every three mature trees found in the forest, one is to be narked for felling. The person selecting the trees to be cut searches about in the forest and marks every third tree of the requisite girth that he comes across, and has them felled. If with such a prescription is combined the observance of simple rules that prohibit the felling of isolated trees of a particular species, and further limit the first choice to trees that are past their prime as seed-bearers, little or no harm will be done to the forests by the time that they can be placed under a more rigorous and accurate treatment. In any case it is much to be preferred to the ordinary haphazard methods that do not take into consideration the actual condition of the growing stock.

Before a simple plan of the nature indicated above, however, can be framed, it is necessary to ascertain:-

(a) the rate of growth, of the particular species exploited, at definite periods of their age; and

(b) the proportion (in number of trees) existing between the various age or girth classes.

As regards (a) the rate of grouth: The best and safest methor of ascertaining this, with respect to an particular species, is to actually measmre at regular intervals, say, of three, four, or five years, the girths or diameters of a good representative series of individuals of all sizes from that of the sapling to the mature tree. The same trees should be re-measured at the end of erery third, fourth, or fifth year, as the case may be, and the process continued till 15 or 20 vears have elapsed, by the end of which time it will be possible to obtain reliable data as to the rate of diameter growth of the species during the different stages of its growth. The latter is not uniform in rate throughout the lifetime of any particular species, hence the necessity for including individuals of all sizes (the girths are proportional to the ages) amongst those measured.

If the measurements are made on series of trees growing on poor, middling, and good soil, more accurate data still will be 
procured, and reliable averages for intermediate conditions of the soil can then be reached by estimation. Of course, very careful records will have to be kept of the measurements, and each tree marked with a distinctive number by which it can be identified, both in the forest and amongst the records.

The necessity for carrying out these olservations on trees that are not likely to be cut or damaged during the periods for which the experiments are to hold good is obrious.

Uther methods of ascertaining the rate of growth are, in the case of tropical trees, not so accurate as that mentioned abore. The usual one of counting the number of rings in the wood and calculating the growth from the data so obtained is only accurate when it is known for certain whether the rings are annual, or bear some definite proportion to the age of the tree.

As a general rule, trees with the deciduous habit strongly promounced at regularly occurring intervals, such as the dry season in the case of species inhabiting the mixed evergreen and deciduous forests, show well-marked differences in the appearance of the tissues formed during the dry and wet periods of the year, and these differences can be utilized in calculating the rate of growth.

Evergreen trees sometimes show the same regularity of difference, but there is in their case no means of ascertaining whether it is an annual occurrence or not, unless a check depending on historical information regarding the actual age of the tree is a vailable.

A safer method is to compare the number of rings in the rood of young trees with the age of the trees as estimated from other evidence, such as the number of rears that may have elapsed since the area on which the roung plants are growing was last cleared by the natives for farming purposes, and the time that has passed since the farm was abandoned as fallow land.

If the average number of rings, as shown on the wood of a large number of young plants, agrees pretty closely with the number of years estimated from the evidence of the natives regarding the period that has elapsed since the farm was abandoned by them, then it may be assumed with safety that the rings in such instances are of annual growth. Similarly. the correspondence between the rings and the age can be ascertained from planted trees the ages of which are known. It may happen that the average number of rings is some exact multiple of the age ascertained from other evidence; the inference then is that two or more rings, as the case may be, are put on annually by the tree, and such data will be sufficient for ascertaining the age of the latter from an ellumeration of the rings alone. The correspondence between the rings and the age having been found, then the age of any particular plant of the same species can be asrertained by counting the number of rings along two or three selected radii of a $\log$ or stump, and taking the average.

The rate of grouth is rot by counting the number of rings that occur along each inch of radius. In the same manner the rate of growth at the different periods of life of the tree can be found. 
Data of the kind mentioned above, to be of any scientific value, should be procured from the average of a large number of observations, and the peculiarities of each species ascertained separately.

\section{(6.) The Proportion existing between the various Age or Girth Gradations.}

Before proceeding to ascertain these ratios by means of linear valuation surveys, it will be necessary to adopt some system of classification of the gradations. The following will be found suitable for present purposes:-

In a well-stocked forest the girths of the trees may, with a fair degree of approximation, be taken as directly proportional to their ages; if, therefore, the girths of the various sizes be equally spaced out between the plants of smallest dimensions, and the average size of the mature trees, a convenient workable scale can be arrived at. 'This scale need not, for the rough approximations now being considered, be divided into more than three classes. For example, suppose the average girth of the mature tree to be $\mathbf{i} 2$ inches, or 6 feet, then the classes (if only three divisions are made), will be as follows:-

The third class (youngest trees) will consist of all plants up to 24 inches in girth.

The second class (middle-aged trees) will consist of all plants between 24 inches and $4 S$ inches in girth.

The first class (mature trees) will consist of all trees between 48 inches and 72 inches and over in girth.

In this example the girths have been equally spaced out at intervals of $\frac{72}{3}=24$ inches, and the various classes are multiples of this interval. The denominator always denotes the number' of classes it is proposed to adopt.

The actual size of the girth will, of course, depend in each case on the size selected as the average girth of the mature tree, and will vary with the species. Suppose the size of the mature tree is found to be only 48 inches, then if only three girth classes are required, the girths will be spaced out at intervals of $\frac{48}{3}=16$ inches. So the classes will be:-

Third class: All plants up to 16 by 1 inches in girth.

Second class: All plants between 16 inches and 16 inches by 2 inches or 32 inches in girth.

First class: All plants between 32 inches and 16 inches by 3 inches or 48 inches in girth and orer.

The whole object of this division into girth classes being to ascertain the condition of the aye gradations with reference to any particular species, the classification of the ages into the thiee divisions, young, midille-aged, and mature, and the subsequent determination of the proportions existing amongst the numbers of the plants found in each of these tasses will be quite 
sufficient to indicate whether the age gradations depart greatly from the normal type or not.

If the number of plants in the youngest and middle-aged classes is found to be less than that in the mature class, then the forest, so far as the particular species of plant under investigation is concerned, is certainly orer-mature, and great care will have to be taken in its exploitation; if, on the other hand, the number of plants found in the youngest class is very greatly in excess of that in the middle-aged class, and the number in the latter in its turn in excess of that in the mature class, then the age gradations approximate to the normal type and a larger number of the mature trees will be available for exploitation without any risk being run of encroaching on the wood-producing capital.

The method of counting the number of plants in each class that has proved to be the best and cheapest in the tropical forests of Burma for rough approximations of this kind is that known as the system of "Linear valuation surveys." It is quite accurate enough for the purpose of framing preparatory working plans and is the most suitable, under existing conditions at all events, for the dense forests of the West Coast of Africa. They are carried out in the following manner.

The person making the enumeration of the trees walks through the forest in a definite direction, say south-west, and in addition to measuring the distance walked orer counts all the plants of the particular species that it is intended to enumerate that he finds within one chain of either side of his line of march. $\mathrm{He}$ enters in his notebook all those that belong to the lowest girth class in the appropriate column for that class by means of a dot or a dash of his pencil and so on for the other girth classes. At the end of the surrey he counts up the number of dots or dashes made and thus ascertains the number of plants enumerated for each class. After a little practice the girth class that a tree belongs to can easily be ascertained by the eye alone without measurement; similarly, the distance of one chain on either side of the line can he estimated by the eye, any small error's made in this respect counterbalancing each other.

When making the linear raluation surveys, care should be taken in hilly country to carry them out along lines that are roughly more or less at right angles to the ridges forming the water-partings so as to include the trees growing at the various elerations abore the levels of the ralleys, and thus obtain a fairer arerage than could be got by keeping the survey at a uniform level above the streams.

At the same time that the countings are made the actual distance or length of line marehed over should be measured in chains by means of a rope. The total distance travelled over (in chains) multiplied by the width of the survey ( 2 chains when a distance of 1 chain on each side of the line of narch is adopterl or nnly nne chain when, as in very dense forest, only half a chain on either side is included in the survey), and divided by ten, will give the acreage of the area on which the trees were ellumerated. 
The area counted over should not be less than 5 per cent. of the total area of the forest.

It will often be found that the particular species that is being counted occurs in patches at very long intervals of a mile or more in such cases, and when calculating the area of the survey, the total length of distance chained over should be reduced by the number of chains travelled over in these blanks.

The results obtained from the valuation surveys should be utilized, not for the purpose of estimating the actual quantity of growing stock in the forest, but with a view to ascertaining the proportion that exists between the numbers of trees in the different girth classes. These proportions or ratios will furnish the most reliable guide as to the condition of the age gradations and their approach to or divergence from that existing in a normal forest.

Once the rate of growth is known and the condition of the age gradations, it will be possible to frame a simple prescription for the fellings.

For example, suppose the age gradations are fairly well represented and it has been found that it requires a period of forty-five years for a tree of the middle girth class to attain the dimensions of those in the mature or exploitable class, then if $G$ be the total number of trees in the latter class, the annual yield, $Y$, of the forest (in trees) will be-

$$
\mathrm{Y}=\frac{\mathrm{G}}{45}
$$

Now supposing the forest is leased for a period say of fifteen rears, then the prescription to cover such a period would be somewhat as follows:-

"The lessee shall not fell during the period of his lease more than $\frac{1}{4} \frac{5}{5} \times G$ mature trees or $\frac{1}{3} \times G$ trees, that is to say, not more than one-third of the total number of mature trees in the forest." This is a simple prescription to apply and check.

In a similar manner, suppose it is determined to work over the whole area in fifteen years and it is found that the particular species being exploited is found more or less uniformly distributed through the area. Then if the area is divided into fifteen annual coups, one of which is taken in hand each year in succession and one-third of the mature trees in each of these coups are removed, the prescription of felling $\frac{4 i}{45}$ trees annually will be satisfied.

For, the trees being uniformly distributed, on $\frac{1}{15}$ of the area there will be $\frac{6}{15}$ mature trees, and $\frac{1}{3}$ of this is equal to $\frac{6}{4}$, the annual yield.

If it happens, as is very likely to be the case with the West. African forests, that the age classes are deficient, especially the middle and younger ones, then the number of vears required to replace the surplus stock of mature trees will, in the example given, be much greater than forty-five years: say it is calculated from the rate of growth of the trees composing the younger classes that another $n$ years will be required to renlace all the mature trees, then the annual felling prescription will be enual to

G 
Such simple prescriptions do not require an exact estimate of the actual quantity of the growing stock in the forest to be made before they can be applied; by felling a definite and high proportion such as $\frac{1}{2}, \frac{1}{3}, \frac{1}{4}$, dc., of the actual number of mature trees met with in the forest, a sufficient check can be kept on the fellings to prevent over-exploitation during the time that must lapse before the forests can be treated under the provisions of more accurate working plans. 'The methods indicated above are well suited to the requirements of wild, imperfectly explored tracts of country sucli as the aftorested areas of British West Africa, where refined methods cannot be introduced at present.

The method under which the forests are to be exploited should be that known as the "selection system." It is the most elastic of all the systems and can be applied to all the rarying conditions to be found in the tropics. Moreover it is the only one that would pay under existing circumstances where ouly a very small proportion of the species composing the forest are worth exploiting.

Where fuel as well as timber for ordinary purposes is in great demand the "coppice with standards" method is the most suitable one to adopt, as it meets both requirements and ensures a certain amount of protection to the soil at all stages of the treatment-a matter of great importance in the tropics.

\section{1).-The Botanical Survey of the Forests.}

It is very important that the forests should be thoroughly explored with a view to eventually compiling a complete botanical inventory of their contents. During the examination of such tracts every effort should be made to secure specimens of the flowers, fruits, and leaves of the plants composing the forest vegetation, as well as to make collections of the different kinds of minor forest produce yielded by them.

In all cases each specimen should have a label attached to it, giving the following information:-

The date of collection.

Locality (district, name of forest, \&c.).

Whether growing in open or dense forest in the evergreen, mixed deciduous, or savannah forests; on hills or close to streams. The character of the soil on which the plant grows, \&c.

Colour of the flowers.

Native name of the plant.

Size to which it grows.

Lises to which it is put.

The specimens should be labelled and numbered serially, and the flowers, fruit, and leaves procured from the same tree should all bear the same number. On account of their bulk some fruits will have to be dried and then kept in boxes-separate from the flowers and leaves-in such cases the greatest care should be taken that the labels attached to the fruit bear the same number as the labels attached to the corresponding specimens of the 
Howers and leaves; otherwise very great confusion is liable to occur.

The specimens should, as soon as possible after being' thoroughly presserl and dried, be forwarded to the Director of the Royal Botanical Gardens, Kew, with a request that they be identified and a list of the identifications sent to the officer who made the collection. The latter person should keep duplicates of the specimens forwarded to Europe, and they should bear the same numbers as the originals. He will then have specimens that have been identified by specialists to refer to from time to time as the orcasion requires. The duplicates will of course be named in accordance with the identification lists sent from Kew. The duplicates should be kept with great care in some central office, like that of the Conservators or of the Provincial Forest Officers.

Representative samples of timber of all the forest trees of the Gold Coast are very much required for the purpose of making a comprehensive study of these woods. The samples should be procured from thoroughly seasoned timber and the botanical identification of the tree yielding the latter should in each case be ascertained from lew and placed absolutely beyond any shadow of doubt.

Certain species of trees to be found on the Gold Coast and Ashanti are so plentiful that every effort should be made to introduce them to and place them on the home markets, because, if a demand for them can be created, the supply is almost inexhaustible and a trade in them will enhance the value of the forests to a very considerable extent.

The most important species in this respect are the Waw-waw (Triplochiton. Johnsonii) and the Dahomah (Piptudenia africana). Both of them rield excellent timber, and that of the latter has lately attracted the attention of some timber brokers in the Liverpool market. It will be well worth the while of Government to place some carefully seasoned and good logs of these woods on that market with a view to introducing them to the notice of the timber merchants. Messi's. Elder Dempster \& Co., are always willing to carry such samples to Europe in their steamers free of all charges. Undoubtedly the best way of seasoning this and almost all tropical woods is to ring bark or girdle the trees and let then remain standing in the forest for two rears or so, till ther have died and the wood has become seasoned. The trees are by this method killed very gradually and the seasoning of the timber is thus carried out in a very effective manner. When "ringing" the tree, care should be taken to completely cut through the sap-wood all round and right into the heartwood. The slightest strip of uncut sap-wood mill often enable the tree to linger on for rears before it dies. In trees that possess no very distinct sap-wood the "ringing" will have to be carried out to a great depth all round and as far inwards as the zone of the dry dead wood, close to the centre of the tree.

It has been found in Southern Nigeria that by girdling or ringing mahogany and cedar trees not only is the fiuber properly seasoned and rendered easier to float, but it is far less 
liable to the formation of ring shakes and cracks when it is felled. The improrement in this respect is rery marked.

Reverting to the $\|^{r} a w-u a w$ and the Dahomah, these trees are so plentiful and universally distributed that it will be possible to place their woods, by the local use of mechanical appliances, on the home markets at a less cost than it is possible to do in the case of the rarer mahoganies and cedars. Even if they command such a low price as two-pence per superficial foot it should pay to extract them. Tow that American and other hardwoods are getting scarcer every year these two species should have a great future before them.

\section{E.-The Training of the Subordinate Staff.}

In early opportunity should be taken of opening a forest sehool to which members of the native staft can be sent for a consse of training in their duties. Such a school should be situated within a reserve in an easily accessible locality, and in the reserve practical lessons in plantation work, thinnings, girdling, felling, coppieing, $\mathbb{N c}$, should be given to the pupils as well as elementary instruction in the conditions affecting plant growth, in the measurement of timber, surveying, the forest lans, and the preparation and submission of forest reports.

Pending the formation of such a school, which is urgently required for the general use of all the Colonies and Protectorates of Britisl West Africa, the Assistant Conservators will have to undertake the training of the men placed under their charge. I few months' course of instruction at one of the botanical gardens would also be a very desirable thing for newly-joined men. The reserve selected as the site for the school should be specially managed with a view to furnishing examples of all the operations described above, and some very useful information can thus be collected regarding the reactions of the different species experimented on towards these various methods of treatment.

Plantations both pure and mixed of the timber-yielding species should be started and careful records kept of the methods of planting adopted and of the results, as well as a general history of all these operations from year to year.

"Regeneration fellings" to stimulate the natnral regeneration of the difterent species of trees should also be rarried out, and records kept of the results thus obtained.

In fact, the reserve selected should serve as a centre not only for teaching purposes, but for research work in connection with the sylvicultural requirements of tropical West African plants, of which but little is known at present.

The reserve should be situated somewhere on the SekondiKumassi Railway, for preference in Ishanti. say between Dunkwa and Oboase. Tnfortunately almost the whole of the land on either side of the railway has in that direction been leased for mining purjoses or as timber concessions. Norertherless it may be possible to romo to some arrangement with the. lessees and lessors with a riew to Government acquiring an area 
of twenty to thirty sipure miles for this purpose. The matter is an important one, and every effort should be made to acquire such a piece of land as a reserve.

Another good locality now that the Tarkwa-Prestea line has bern started is the trar.t of country drained by the Mansi River and its feeder, the Opon River. I reserve somewhere about here would be accessible from both railways. The forests in this district are very rich in mahoganies and cedars, but most of the land close to the streams nentioned above has been leased to timber merchants and contractors, and some difficulty may be experienced in acquiring a sufficient area for a reserve. The selection should be made with great care after full cousideration of the ronuirements, and had better be postponed till a Eorest Department has been established.

\section{F.-Forest Plantations.}

Plantations of all the more valuable economic species should be started in the reserves and augmented every year under the provisions of a well thought-out plan of operations. Efforts should also be made to induce the native communities to take up the planting of the indigenous rubber tree, Funtumia elustica, on a large scale, and the members of the native forestry staft should be freely lent out to the different districts for the purpose of instructing the inhabitants in the best methods of cultivating that species. This system has been attended with the happiest results in the Central Province of Southern Nigeria, where a large number of rubber plantations belonging to the natives are now in existence.

\section{G.-The Inspection and Supervision of Timber Concessions and Licensed Areas.}

It will be an important part of the duties of every forest officer to exercise adequate supervision over the working of timber concessions and licensed areas, and to check as often as possible the work done by their subordinates. In addition to this, which will require frequent tours of inspection, it will be necessary to keep a wateli on rubber nurseries and young plantations, and to make adequate provision for their annual extension and their protection. The various points requiring attention may be enumerated as follows:-

(a.) The infringement of the minimum girth rulc.-Any cases of undersized felling by concessionaires or licensees should be immediately reported to the Conservator.

(b.) C'arelessness of felling and the causing of injuryto young growth.-The concessionaire or licensee should be informed in writing of any cases of this sort that are brought to the notice of the forest officer, and he should be warned against recurrences of such acts. Cases of persistence in such carelessness should be reported to the Conservator. 
(c.) Wasteful logging.-This is inevitable to a certain extent, but attention should be drawn to any excessive and uncalled-for waste that may occur, and persistence in it should be dealt with as noted above under $(b)$.

(d.) The inspection of plantations made by concessionaires to replace the trees felled by them.-The forest officer should see that the species planted is really the same as that felled (cases have occurred where the seeds planted belonged to species different from those which they were intended to replace), and that they are planted close enough together to enable them to acquire a sufficient height in a few years' time to escape being suppressed by other growth.

If instead of planting, the freeing from dominant growth of seedlings that have sprung up naturally in the forests is taken in hand, then care should be exercised in ensuring that such seedlings are sufficiently cleared from growth to enable them to shoot up without further trouble.

(e.) Every opportunity should be taken to inspect the books of concessionaires and licensees and to check therein the number of trees and $\log$ s shown with the numbers actually found on the stumps in the forest.

(f.) Adequate supervision should be exercised over the work done by the subordinate staff, and any case of abuse on their part of the powers given to them should at once be enquired into and suitable punishment inflicted.

\section{H.-General Forest Policy.}

This question has been dealt with to some extent when discussing the legislative measures necessary for the establishment of forest conservancy on a satisfactory footing. It now remains to state briefly the forest policy that should be pursued with a view to consolidating the various measures proposed and guiding them along the proper channels.

I trust that I have sufficiently explained the importance of establishing reseres of a sufficient extent to meet all the demands for forest produce likely to arise in the future, and for the purpose of realising those beneficial effects on the climatic factors of a country that are usually associated with the presence of large masses of forest regetation.

The keystome to all forest conservancy is reservation. Tuless the paramount Government can ensure the thorougl: and legal protection afforded by reservation to estates that are meant to be managed as forests, real conservancy is out of the question, and the forests as such will gradually disappear off the face of the land. 
Reservation being ensmred, the forests should be managed with a view to supplying a sustained and increasing yield of produce, both for local requirements and for the home markets, and this can all be brought about with but little interference with the reognised rights and privileges of the inhabitants. The supply of their wants should be the first care of the management, and after that can come the exploitation of produce for the European markets. At present there are vast forests available for both purposes, but a time will come when they will be so restricted in size that the utmost difficulty will be experienced in supplying the various demands. It is, therefore, highly desirable that the best areas should at once be selected and marked oft as estates for the permanent supply of those wants before the former hare been much damaged or destroved; and if the two-fold character of the markets to be supplied is kept in mind, it will be realised that the creation of a few reserves will be totally insufficient to meet the requirements of the case. Nothing short of something like 40 per cent. of the wooded area will be required if the inhabitants of the country are to be provided with that share of forest produce for their daily and other requirements to which they are justly entitled.

Concmrently with this remoral of produce, measures will have to be taken, by the properly arranged cutting of the ripe material and by sowing and planting, to replace what has been remored from the forests, and thus ensure a continuous supply in the future.

None of the measures, however, will be of much avail unless they are continually exercised and enforced, any breaks in the continuity will be fatal both to the management and to the results originally contemplated. Continuity of purpose and action are the rery breath and life of sound forest administration. Frequent changes of policy, management, \&c., bring about that uncertainty and want of finality in the results that it is the main object of scientific forestry to aroid. A forest crop, as it is, takes a rery long time to mature; and the result of continually altering the treatment to which it is subjected can, under such conditions, be easily imagined. The loss of time alone is immense.

As regards the danger threatening the wooded areas of Aquapim, by the encroachment on them of the adjacent grass lands and sarannah forests, I fear that the damage alreadr done is too great to be repaired except by the expenditure of large sums of money, which the Administration will at present scarcely be able to aftord. It is, however, well within the means of the Government to stop the further spread of this damage and secure for the further cultivation of cocoa, rubber. and other tropical crops, land that must in time, under the present methods of farming, he lost for that purpose. Br preserving a broad belt of forest between the planting centres and the dry grass country, a suitable harrier against the spread of the latter can be provided for. This protective belt of forest should be strictly reserved. 
I understand that there is a fairly extensive piece of Crownland between Christianborg Castle and the cantonments. This should, I think, be re-atiorested, partly for the purpose of supplying Accra with cheap fuel and partly as an object lesson in how unfertile arid wastes can be reclaimed.

Indications are not wanting that the climate of the country round Winneba, Pram Pram, and Accra is gradually becoming drier and changing for the worse, and it may possibly become imperative some vears hence for Government to arrest this process of desicration by means of irrigation work and re-aftorestation; hence, timely experiments should be undertaken on a small scale to ascertain the most suitable plants for this purpose, and the best methods of growing them. The importance of preserving the forests corering the catchment basins of streams flowing through those dry districts should also be kept in mind, especially with a view to the utilisation of their waters for irrigation puiposes.

In conclusion, it is much to be hoped that adequate steps will be taken to secure the protection and proper management of some of the richer portions of the magnificent forests of Ashanti and the Colony, forests the like of which it would be rery hard to match anywhere in Africa, and which form a very valuable asset of the country and the Empire. Any sacrifices made to attain this object will be repaid a hundredfold in the future. The revenues derived from timber and rubber will amply suffice to cover the cost of all such undertakings.

\section{PART III.}

C.-CONCJUSION.-Brief description of the Climate and Physical Features of the Gold Coast and Ashanti._Short Acrount of the Conditions affecting Plant-grouth.-Classification of Plant formations.-Types of II est African formations and their characteristic Plants. - The distribution of the Forests.-Erports and Imports of Forest Produce.list of Ternacular. Tames of Plants.

The Gold Coast with its two administrative divisions or dependencies, Ashanti and the Northern Territories, comprises an area of something like 82,000 square miles. It is situated on the coast of Guinea, between the French possession of the Irory Coast and the German Colony and Protectorate of Togoland, with the frontiers of which its western and eastern boundaries coincide. It has a seaboard extending from $: 3^{\circ}$ west longitude to $1^{\circ}$ east longitude, and is hounded on the worth by the 11 th parallel of north latitude and the French Soudan and J)ahomer. The greatest length from north to south is about 450 miles. It is thus wholly situated within the northern tropic. 
Drainage Systems.

The chief rivers draining this extensive tract of country are :-

1. The Volta, with its two large feeders the Black and White Voltas-the former of which rises in the Mina Mountains of the Western Soudlan, and the latter some hundred miles due north of the important town of Wagadugu in the French Soudan. The Black Volta from the $11^{\circ}$ north parallel as far south as about $8^{\circ} 40^{\prime}$ north forms the boundary between our possessions and that of the French. It then flows in a south-easterly direction till within a long day's march of Kintampo, after which it makes a big loop to the north, is joined by the White Volta, and resumes it south-easterly direction; this it keeps as far as the small village of Epum on the north-eastern border of Ashanti, when it turns to the south, and after running in that direction for about a hundred miles, again, in the neighbourhool of Akusa, bends away to the south-east and finally empties itself into the Kitta and Adda lagoons.

It is a fine river, but unfortunately the channel is much obstructed in places with rapids. The Thite Tolta drains a considerable portion of the Northern lerritories. The most important tributaries on the right bank of the main or Black Tolta are, within our limits, the Tain, Pra, Sene, Sumi, and Afran Rivers, all of which, except the last, drain the northern portions of Ashanti.

2. The Tano River.-This rises in north-western Ishanti, and after flowing in a more or less north and south direction for nearly the whole of its course empties itself into the Tendo Lagoon on the extreme south-western border of the Colony, close to the coast town of Half Assini. It is also obstructed by rapids, but they are said to be not rerr formidable, and the obstructions causing them are capable of being remover. The Tano River drains the best forests of Ashanti and the Colony-a wooded area of several thousand square miles.

3. The Pra River.-Rising in the high hills of Okwawn and Eastern Akim, this river flows for the greater portion of its journey in a south-westerly direction; at Sarmang it turns to the south and flows into the sea close to the town of Shama. It drains an extremely hilly tract of country. and is. like the others, rendered unnavigable by the presence of rapids. The most inportant feeders on its right bank are the Anum River, which drains the country to the east of the sacred lake, and the Offin with its tributary the Adra. They both drain the southern and south-restern portions of Ashanti. On the left hank it is joined by two important feeders, the Inwi and the Birrim, the latter of which is much the larger of the two and drains one of the best cocoa-growing districts.

4. The Ankobra River.-This stream rises in the extreme northern portion of Tpper Denkira, close to the mining centre of Bibiani, and is confined for the whole length of its course to the limits of the Colony. It flows almost due north and south through a very rich mining and timber country, and falls into the sea close to Axim. 
Wher less important rivers are the Nakwa, in the Salt Pond dis. trict, the Amaso in Irimneba, and the Densu in the Accra district. These rise in the Atikwa and Aquapim hills, and all of them flow in a general north to south direction. In the neighbourhood of the sea they flow through open country covered with low scrub or savannal forest. In the eastern portion of Ashanti a small tract of densely-wooded country is drained by the Jia River, a tributary of the Komoe, which is the most important water-way of the French Irory r'oast.

\section{The Water-partings.}

Generally speaking, the country along the sea-board is undulating in character, especially to the east of Winneba, where extensive plains exist between the coast and the well-marked hill ranges of the interior, which approach on an average to within 15 to 20 miles of the sea shore. Wrestwards of the above-mentioned town the undulations are much more pronounced and give rise to low hills with abrupt slopes facing the sea. The coast line is on the whole bold and well defined, and the long stretches of low-lying mangrove swamps, so characteristic of the Southern Nigerian coast, are here a very subordinate feature of the country.

As one recedes from the coast line northwards the land becomes very hilly, well wooded, and rich in perennial streams, and these characters are maintained till the central plateau of Xorthern Ashanti is reached, when the dense forests gradually give way to the open sarannal formations in which the water supply during the dry season is poor and the contours of the country again assume an undulating character. These upland plains are, however, dominated here and there by well-marked rocky hills that sometimes reach an altitude of over 1,600 feet. The plateau is interrupted by the lower valley of the Black Volta River to the north, but reappears, I understand, a short distance inland from the left bank of that river, and gradually increasing in height culminates in the tableland on which Gambaga is situated. It must attain an altitude of close on 2,000 feet in that Province.

The approach to the Ashanti plateau from the east is much more gradual as the valley of the main Tolta leads up to it from that direction. This ralley is nerertheless rery much contracted in places where prominent hill ranges, running in a north-easterly direction, are in the ricinity of the village of Mem broken through by it: beyond this gorge the country opens out on to the Afram Plains, which gradually merge into the North Ashanti plateau. The Volta River is practically the only drainer of the latter, and the plateau is lowest in the north-east comer of Ashanti.

The most pronounced ranges of bills are:-

(1.) The water-parting between the Offin River and its tribuiary the Adra. 'To the north of N'Kwanta it culminates in a range over 1,600 feet in altitude.

(2.) The divide between the Tano River and the Ankobra; this also reaches a similar altitude. 
(3.) The Oboase hills forming the divide between the Offin and the Jim Rivers. They culminate in a peak that is close on 1,800 feet above sea level.

(4.) 'The Dampia and Moinsin ranges forming the divide between the Jim and Anum Rivers, both of them tributaries of the Pra.

(5.) The Bompata hills forming the water-parting between the main Pra and its feeder the Awere.

(6.) The Obo-Abetifi group forming the sources of the Pra and Afram Rivers. The highest peak reaches an altitude of 2,200 feet above the sea. This is the most prominent block of hills in the country, and it assumes the formation of an irregular plateau with steep escarpments on all sides, except to the north, where the descent to the Afram plains is in comparison rather gradual. 'The climate of these hills is delightfully bracing, and from the higher peaks magnificent views of the vast undulating plains to the north can be obtained.

(7.) The Bogora range forming the sources of the Birrim and Ahurum Rivers. IIt is a prominent lange, having an average altitude of about 1,800 feet.

(8.) The Kyebi hills, on which the Densu River rises. They reach an altitude of close on 2,000 feet.

(9.) The Aliwapem and Akropong hills, about 25 miles to the north of Accra. They culminate in peaks about 1,600 feet above the sea level.

(10.) The Krobo hills. These consist of some extraordinarily steep, isolated hills, situated to the north-east of Aburi, in the neighbourhood of Akuse.

(11.) In addition to the above there is a very prominent range of rocky hills on the north-western border of Ashanti in the Banda district, and some bold escarpments between N'Koranza and Chichewere and the neighbourhood of Mampon.

\section{Climate.}

The climate of the Gold Coast and its dependencies, so far as rainfall and the relatice humidity of the air are concerned-and these two factors after all have the most influence on plant growth in the Tropics - can be ascertained from the data given below. which have been compiled from statistics given in the Gold Coast anmual reports for the five rears, 1903 to $190 \%$. Those for the seaport town of Sekondi are basel on the figures for three rears only-namely, 1905 to 1907.

Arerage Rainfall and Relative Mumidity of the Air for the five years, 1903 to 1907.

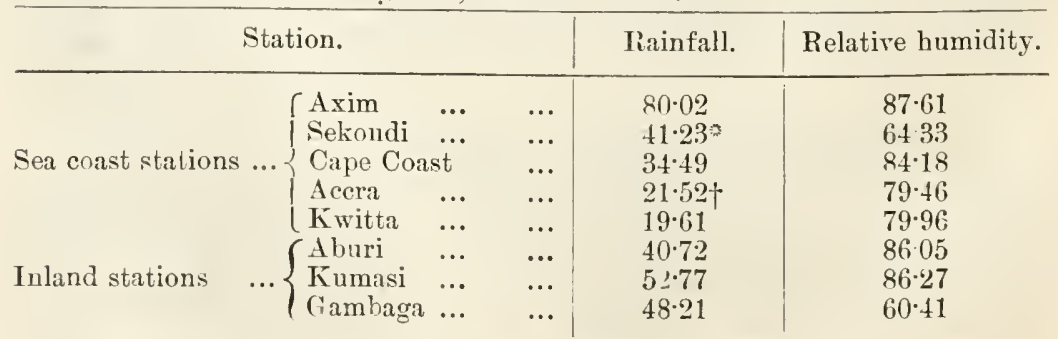

The mean of :' years' obser rations only (1905 to 1907).

$\dagger$ 'The mean of 20 years' obse: vations is $27 \cdot 35$ inches 
These figures show that the rainfall along the coast line decreases as one proceeds eastwards from Axim, where it is 80 inches, to Kwitta, on the extreme eastern extremity of the Colony, where it is only $19 \cdot 61$ inches. That of Kumasi, which is situated in the northern half of the forest region, is $52 \cdot \pi /$, and of Gambaga, the most inland station, close on the 11th parallel of north latitude, 4S.21 inches. Aburi being a hill station shows a climate characteristic of such localities, in its relatively high degree of humidity, which is 86.05 for a rainfall of only 40.72 inches, against $87^{\circ} 61$ for Axim, where the rainfall is as high as S0 inches.

Gambaga shows the extremes of a continental, tropical climate, and has the lowest relative humidity, viz., $60^{\circ} 41$, of those recorded. The coastal stations, on account of their proximity to the sea, possess a higher relative humidity than the recorded rainfalls would otherwise lead one to anticipate.

The maximum shade temperatures range from $91^{\circ} .56 \mathrm{~F}$. at Gambaga to $81^{\circ} \mathrm{F}$. at Aburi, and the minimum shade temperatures from $\pi 0^{\circ} \mathrm{F}$. at Kumasi and Axim to $\tau 6^{\circ} \mathrm{F}$. at Kwitta, and $75^{\circ} \mathrm{F}$. at Cape Coast. These temperatures are well within the normal range for tropical plants. The seasons of the year may be divided into the following groups, viz.:-

(a.) The wet season proper, extending from about the middle of May to the end of July.

(b.) The small rains, extending from the beginning of September to the middle of November.

(c.) The dry season proper, extending from the middle of November to the end of February.

(d.) The small dry season, which consists of a break in the rains and is practically confined to the month of August; and

(e.) The tornado season, from the beginning of March to the commencement of the heary rains in May. This is an intermediate season in which, though thunder storms and showers of rain are pretty frequent, yet the number of dry days is much in excess of those on which rain falls.

The limits given above are, of course, only approximate, and they are sometimes widely departed from, but, on the whole, they indicate with fair accuracy the sequence and character of the seasons

1)uring the months of December, January, and February a very dry, cold wind, known as the Harmattan, blows from the north and north-east at pretty frequent intervals, and sometimes lasts for a great number of days in succession. It is accompanied by a dust haze consisting of fine particles of quartz, diatoms, \&c., and its contact with the hot, moist air near the coast often brings about the fogs and mists so prevalent at that season of the year. The Harmattan is generally supposed to blow across the sandy wastes of the Soudan on its way to the sea, and to carry with it the finer particles of sand from those regions. Whatever its origin, it has a very marked effect on the regetation, and, to a 
large extent, determines the distribution of the different types. As one proceeds inland and northwards from the coast, the Harmattan is found to be more pronounced and to last for much longer intervals at a stretch till in the interior beyond the 10th parallel of north latitude it is the prevalent breeze at that season of the year. Rainfall has, of course, the most influence on the vegefation, hut at the same time the action is much modified by desiccating winds of the nature described above. Then these are practically a constant feature of the season for several months at a stretch, the country rapidly dries up, though the actual total rainfall may have been abundant enough to support luxuriant vegetation but for the prolonged dry weather brought about by such winds. Gambaga is a case in point; the mean annual rainfall, as far as available data go, is 48.21 inches, which is only 4.56 inches less than that of Kumasi, a station situated within the evergreen forest belt; but the difference between the mean relative humidity of the air in the two places is rery great indeed - 60.41 per cent. in the former place, and $86.2 \%$ per cent. in the latter. It is this reduced humidity, brought about by prolonged spells of dry weather, that accounts to a large extent for the rery pronounced difference in the regetation of the two localities.

There is but little doubt that the presence of extensive forests in the vicinity of Gambaga would considerably temper and diminish the drying action of the Harmattan winds and make the country moister than it is, though it may result in no very marked improvement in the rainfall, whilst conversely, the persistent destruction of the forests for a good distance round Kumasi rould result in the soil becoming drier. in the water supply being reduced, in the drying effect of the Harmattans being intensified. and in a change of the type of regetation.

Forests act as protective covering to the moisture in the soil: remove them and rou diminish the quantity of moisture in the soil. This decrease reacts in its turn on the forest regetation, and brings about a change in its character that makes it more suited to the altered conditions, and so on-the climatic factors and the forests act and react on one another, by mutual adjustments, but the continued destruction of the latter inevitably results in at diminished water supply.

But beyond this, forest rezetation is responsible for a high percentage of the total amount of water held in suspension by the atmosphere, and forests exercise a marked effect in increasing the relative humidity of the atmosphere in their neighbourhood. A high relative humidity means moister conditions all round, both as to soil, the water supply of the country, and greater resistance to desiccating influences, by its retarding action on eraporation.

When it is resollected that the amount of water vapour transpired from a large mass of forest regetation is several hundred times greater than that eraporated from a water surface of the same area, it will be understood that it does not require a very large portion of the earth's surface to be covered with forest vegetation for the amount of moisture transpired $\mathrm{by}$ it to exceed 
that from all other sources, the sea included. In fact, it is probable that a high proportion of the total rain precipitated on the surface of the earth consists of the condensed rapour transpired hy plants. The rapour may not always be condensed in the actual vicinity of the forests from which it is transpired, but it is in all probability condensed somewhere else, and that place has to thank the forests for their contribution to its rainfall.

In this connection a very interesting article in the October number (1908) of the "Indian Forester" should be consulted.

Kumasi is a good example of a locality in which a comparatively poor rainfall (52.7 inches) is assoeiated with the presence of extensive evergreen forests and a high relative humidity of $86 \cdot 27$ per cent.

There is but little doubt that here the high relative humidity, and the copious water supply which this ensures, are directly attributable to the existence of these immense forests. An annual rainfall of only 52 inches would, in the absence of such forests, be totally inadequate in a tropical region like that of the Gold Coast to support the type of regetation that actually does exist round Kumasi. The exposed soil (in the absence of the forests) would be rapidly deprived of its moisture during the Harmattan season, and this would re-act on the vegetation, and the latter would then acquire a more or less xerophilous habit.

For practical purposes it is immaterial to enquire whether in the first instance the humidity of the air favoured the growth of the forests or the growth of the forests produced the humidity. Humidity cannot be roluntarily influenced by any means known to man, except by aftorestation and deforestation; for the effects of irrigation are negligible in comparison with the effects brought about by forests, so far, at least, as the humidity of the atmosphere is concerned.

Forests, once they have been started, whatever their origin, to a large extent mould their own destinies, and gradually change the climatic and other factors of the adjacent lands in a manner suitable for the further spread of such regetation, provided, of course, that they are not interfered with by man.

No one who has actually experienced the change brought about in his sensations, when stepping from the cool and grateful shade of a tropical forest into the fierce dry heat of an adjacent treeless plain, can fail to realise what the existence of such a forest means to the locality, and can ever entertain any doubts afterwards as to its beneficial action on the soil and climate.

\section{The Soil.}

'The most prevalent soil of the country is a red sandy loam, coloured by the presence in it of ferric oxide. The amount of sand in the clay varies in different localities, but has no marked effect on the vegetation within the maritime forest zone and the heavy rainfall associated with it. Outcrops of laterite are also frequently met with in the same region, but the edaphic influences due to such changes in the soil are completely orn- 
shadowed by the very much more powerful action exercised on the vegetation by the copious rainfall.

Metamorphic rocks of a granitoid and schistose character, together with frequent outcrops of sandstone and quartz, form the chief materials composing the more important hill ranges; in the hinterland, where the rainfall is small or a pronounced dry season occurs, the regetation is much modified by the presence or absence of the different soils due to the weathering of the above rocks. Here, again, laterite reappears as extensive outcrops of a hard, stony, porous character, containing vitreous or cellular concretions of ferric oxide or ferric hydrate, and exercises a profound influence on the plant growth. Its presence is always associated with poor, gnarled, stunted regetation, exhibiting a very marked xerophilous character.

The sandy soil along the sea coast in the vicinity of Accra, for a considerable distance inland from the shore, is much impregnated with salt, which is blown up with the spray and carried a good way in by the strong sea breezes so prevalent in that locality. The vegetation about here, especially that of a slirubby or herbaceous character, has acquired the halophytic habit.

\section{The Influence of Climate on Vegetation.}

Before dealing with the distribution of the various types of forest to be met with on the Gold Coas., it will be convenient, and it will help to explain the reasons governing this distribution, if a brief description of the reactions on plant life of the climatic and other factors of the environment is given here.

The flora of the Gold Coast belongs to the zone known as the Tropical Zone, but the local distribution of the various types of regetation found there is determined, within the limits of the zone, by the amount of atmospheric precipitation prevailing in any one locality. According to the degree of precipitation, the areas may be divided up into climatic districts, with each of which is associated a particular type of vegetation; within the districts, again, rariations in the physical and chemical constitution of the soil give rise to other modifications due to cdaphic influences.

The districts may be grouped under three climatic types in accordance with the amount of atmospheric precipitation experienced in each. They are:-

(a) the Hygrophilous climate,

(b) the Xerophilous climate,

(c) the Tropophilous climate,

to which correspond the Hygrophilous, Xerophilous, and Tropophilous types, respectively, of regetation.

These modifications are brought about by the conditions known as physiological moistness and driness. which do not always coincide with physical moistness or dryness.

Anything that affects the arailable supply of moisture, so as to bring about this phrsiological moistness or dryness, is accompanied by hygrophilous or xerophilous regetation, as the case 
may be. When these condition alternate one with another with a regular periodicity, we get the third or tropophilous type.

The boundaries between these divisions are, however, not sharply marked in mature, and intermediate conditions are often met with. 'Those mentioned, however, correspond to the maximum adaptations acquired under pronounced conditions of physiological wetness or dryness, and their periodical alternations.

This relation of plants towards water is expressed by structural characters; where the latter is such as to farour the exit of the water absorbed by the roots we get the class known as Hygrophytes, and where it retards the exit of moisture, the class termed Yerophytes; Tropophytes are plants the structure of whose perennial parts is that of Nerophytes, and that of their parts (leaves) present only in the wet season that of hygrophytes.

Wherever moisture is abundant, and, therefore, the danger of desiccation absent, plants have, in order to prevent any possibility of stagnation in the water-current (transpiration current) that distributes nutritive salts to the various parts requiring them, acquired contrivances that hasten the exit of water; such plants are Hygrophytes.

Where, on the other hand, the supply of moisture is scanty and the strengtl of the transpiration current relatively to the water supply has to be regulated so as to guard against physiological dryness, the corresponding adaptations have brought about the plants known as Xerophytes.

Hygrophytes have a weakly-dereloped root system, elongated axes, large thin leaf-blades, and they but rarely develop thorns (not prickles). In moist tropical forests with a heavy rainfall, the plants often develop leaves with a loug "dripping point," and the leaves frequently have a velvety surface on which the water spreads out into an extremely thin layer that rapidly evaporates. The leaves, again, possess well-developed air-containing intercellular spaces that strongly promote transpiration, and they are, especially in the case of trees forming the moist tropical evergreen forests, rich in Hydathodes or organs for excreting liquid water. The heavy showers of the so-called "dew-drops," that are so often noticed late at night and in the early hours of the morning, to drip oft tropical forest trees in a moist locality, mainly consist of water excreted by these Hydathodes.

Finally, Hygrophytes, are to a large extent Ombrophilous or rain-seeking, and their foliage is capable of being wetted.

Xerophytes, on the other hand, have to accommodate themselves to conditions that involve the danger of physiological dryness. This may be brought about by increased transpiration (with respect to the available water supply) due to the following causes:-A dry atmosphere, reduced atmospheric pressure (rarefaction of the air), and strong light, or by reduced absorption due to the scarcity of free water in the soil, excess of soluble salts or humous acids in the soil, or to a low temperature of the soil. 
In nature, usually a combination of all these factors or the greater number of them has to be faced by xerophilous plants in the localities they inhabit, and their adaptations to these conditions have brought about the following adaptations of etructure.

Reduced transpiration is brought about by a decrease in the transpiring surface of the leaves for the same mass of plant substance by the formation of a thick cuticle on the exposed surfaces of the leaves, by the reduction in size of the intercellular air spaces of the leaf, by a sinking of the stomata, and by the presence of felted hairs containing much air.

In ardition to this, Nerophytes are often characterised by the presence of water-storing cells (double epidermis, aqueous tissue, mucilage cells, \&c.), an increase in the ressels and sclerenchymatous tissues, lengthening of the palisade cells of the leaf. a copious root system, underground stems, the power to orient their leaves so as to aroid insolation at the hottest and brightest time of the day and, in the case of those possessing pinnate leaves, the power to open or close them according to the degree of illumination: the production of thorns from reduced leaves and shoots, by being ombrophobous or rain-avoiding, and by the formation of thicker and more fleshy or proportionately more leathery leares, or by the reduction of the latter to rudimentary organs, in which case the axes become rich in chlorophyll.

These modifications are chiefly confined to the leaves, which are the organs most concerned with the act of transpiration; modifications of the axes (stems), howerer, are not rare. Those of plants belonging to the Cactus family become slort and thick and even spheroidal, and are filled with a mucilaginous sap. Similarly the stems of some Euphorbias become succulent, and even those of gigantic trees like the tropical African Baobab tree (Adansonin digitata) acquire a monstrous, gouty shape, and the rood, becoming soft, juicy, and spongy, forms at rast watel-reservoir.

Water-cells have a sinilar fumction; they rapidly fill up whenever the water supply is temporarily increased (during rainy weather) and vield their contents to the assimilating cells as the supply of moisture becomes reduced.

As regards ombrophoby, Xerophytes perish if they are exposed for a few days to continuous rain, and their leaves cannot be wetted except after prolonged exposure to water.

The most important natural habitats where Xerophytes thrive are:-

(1.) Districts with a dry substratum, dry air, occasional or persistent heat, and intense illumination.

(2.) The surfaces of the bark of trees (with reference to the growth on it of epiphytes), rocks, \&c.. where, owing to a want of sufficient depth of the substratum, any moisture deposited on them is rapidly eraporated.

(3.) Sandr, gravelly, and other similar soils which, owing to their permeability, are rapidly dried up. 
(4.) Sea-shores and some soils in which the supply of salt is abundant.

In all these habitats physiological dryness is a standing danger, and only Xerophytes can successfully occupy them.

\section{T'ropophytes.}

Plants occupying a habitat that is alternately hygrophilous and xerophilous in climate. have adapted their structure to these periodically different conditions, and are known as tropophytes. Such a climate is one in which a season of fairly abundant rainfall is invariably followed by a well-marked dry period of the year. Immense tracts of the earth's surface experience a climate of this sort, and it is immaterial to the plant whether the periodical dryness is due to a scarcity of atmospheric precipitation or to a low temperature of the soil, the latter condition being just as capable of inducing physiological dryness as the former. Hence, large portions of the 'Temperate Zones, where severe winters prevail, are occupied by Tropophytes as well as extensive areas in the Tropical Zone.

The difficulty of adapting the structure of plants so as to satisfy the requirements of these two very dissimilar periods of the year has been met by their perennial parts, such as the stems, branches, roots, \&c., being modified to withstand rerophilous conditions, and their temporary parts, the leaves, being adapted to hygrophilous conditions such as prevail during the wet season. When the dry period of the year comes round and transpiration has to be reduced, the leaves are shed, a simple and effective device to guard against all possibility of danger from excessive transpiration during the season of physiological dryness.

\section{Characteristics of 'Tropophytes.}

(1.) They sacrifice (by sherding their leaves) the greater portion of their transpiring organs at the beginning of the physiologically dry season, whether the latter is brought about by a dry climate or a cold one. Most of the woodr plants shed their leaves at this season. Many herbaceous plants lose all their sub-aerial parts and merely retain their subterranean ones, which transpire but slightly.

(2.) Periodically foliaged tropophilous woody plants have hygrophilous leaves, but xerophilous axes (stems, \&c.) and buds. The stems and branches are protected against drought by a well-developed bark or thick layers of cork, and the buds by hard and often lacquered scales.

(3.) Evergreen tropophilous plants have xerophilous foliage as well as xerophilous axes and buds.

The most obvious characteristic is the periodical foliation and defoliation which in some localities is most conspicuous, as the foliation is often very luxuriant during the ret season, and in marked contrast with the gaunt, bare-stemmed habit assumed during the dry season. 
A taint of the tropophilous habit is often to be observed in both relophytic and hygrophytic districts, but it is not pronounced, and is generally restricted to a thinning of the foliage merely, and does not extend to complete defoliation.

\section{Climatic Formations.}

The differentiation of the earth's vegetation is controlled by three factors-heat (determining the zones), atmospheric precipitation, and winds (determining districts), and soil; the latter of which is more local in its influence, and brings about edaphic formations.

'Two cecological groups are to be distinguished; they are:-

(1.) Climatic or district formations, governed by the atmospheric precipitations.

(2.) Edaphic or local formations, determined by the nature of the soil.

The climatic formations can all be traced back to three main types, viz., Woodland, Grassland, and Desert.

The first two types are closed formations, in which only such plants can thrive as have acquired an optimum adaptation to all the external factors, and this fact enables them to keep out. less favoured competitors. Here the struggle is keen, and numerous seedlings perish in consequence; more components cannot be admitted. Deserts, on the other hanl, are open formations, in which the conditions are so serere that only a few plants are able to occupy them, and there is plenty of space available for others if the latter could be found.

The components of woodland formations consist of roody plants, generally trees. The latter are cosmopolitan in their distribution, and their growth is entirely prevented only by such a degree of drought (due to scarcity of moisture in the soil or to its frozen condition) as excludes all kinds of plants, with the exception of the lower cryptogams. The depth of the root system of trees enables them to thrive in areas where long seasons of drought accompanied by great heat recur periodically. Providing there is a continuous supply of moisture within reach of the root-tips, it is immaterial at what season of the year the supply is renewed.

Dry winds, however, on account of their pronounced action in increasing transpiration, are decidedly hostile to tree growtl, as they tend to reduce the supply of moisture even at great depths of the soil, and their effect is more felt at the greater heights above the surface of the ground, that are usually attained by the tops of trees, than at lower levels closer to the surface.

Grassland, on the other hand, is mainly occupied by grasses and herbaceous plants; also, though less frequently, by shrubs and dwarfed trees. The latter are, however, very subordinate constituents of the typical formation. Owing to their shallow root systems, grasses are practically dependent on the supply of moisture in the upper superficial layers of the soil, and this supply is continually exposed to the danger of being considerably 
reduced by evaporation; hence, for their successful growth frequent, if even weak, showers of rain are necessary during the vegetative period, viz., the spring and early summer (March to May), and a moderate degree of heat during the same period. They are inditterent to the degree of moisture in the sub-soil or, during their resting periods, the winter months (November to February), to drought and exposure to dry winds. On account of their lower stature and the proximity to the surface of the ground of their vegetative organs, they are subjected to moister conditions of the atmosphere and do not suffer to anything like the same extent from dry winds as plants composing the woodland formations do. The most favourable conditions for the latter are a warm vegetative season, continuously moist sub-soil, and damp calm air.

Of great importance to grassland is, in the tropics, the formation of heavy dew during the early periods of vegetative activity and the indifference of the grasses to the fierce annual fires that sweep over the drier portions of West Africa during the winter season.

These two great formations of Grassland and Woodland are continually hostile to each other, and in the struggle that often takes place between them, the victory in any locality rests with the formation that is best adapted to the climatic and edaphic conditions prevailing there. Under the most favourable conditions for woodland, we have the hygrophilous trees; with less favourable conditions the tropophilous and xerophilous trees; and last of all, xerophilous scrub, which corresponds to the worst enviromment. The corresponding conditions for the existence of grassland are associated with the presence of pure savannal, savannah-forest, and small isolated patches of grass-land within districts with hygrophilous and tropophilous wood-land climates.

With reference to the attitude displayed by these two formations towards one another, it is important to note that in accordance with the climates now prevailing, the domain of each has become more or less defined and limited, but that very small changes of climate will suffice to renew the contest, and, above all, that in districts where the climate is such as not to lecidedly favour one or the other, the action of man is sufficient to start the struggle. Moreover, though in a decided woodland clinate, forest will generally succeed to destroyed forest growth, yet the new forest is almost invariably of a more xerophilous (dry) character. And if the process of destruction is repeated at pretty frequent intervals, it is followed first by savannah forest and then by pure sarannahs.

\section{Edaphic Formations.}

These are dependent on the character of the soil, and for the purpose of this report may be divided into the following types:-

(a.) Fringing Forests. - They are similar in character to a hygrophilous forest, but are dependent on a telluric supply of moisture, and are hence confined to the vicinity of the beds of streams and similar collections of water. 
(b.) Swamp Forests, the trees composing which are adapted to growth in stagnant water.

(c.) Mangrove Swamp Forests. - This is a formation that is confined to tropical shores where the climate is hot and humid. The plants composing it are restricted to the area comprised between the limits of high and low tide, where the water is not otherwise much agitated by constant strong winds and currents. They have adapted themselves to growth in a salty stratum that is alternately flooded by sea water and exposed to the air by the fluctuations of the tide. They are characterised by their stiltlike roots and the possession in the latter of pneumatophores and other devices for absorbing oxygen and transporting it to such subterranean parts of the trees as may require it.

Less important elaphic formations are represented by rock plants (Lithophytes).

Tropical Woodland, so far as it is dependent on climate and not on the eftects of the soil, may be divided into the following four kinds:-

(1.) The Rain Forest, or the moist tropical evergreen forest of Indian forester's.

It is an evergreen forest, hygrophilous in ehuracter, with an average height of more than one hundred feet, frequently much taller. It is rich in thick-stemmed lianes and in woody as well as herbaceous epiphytes, and is associated with a constantly or nearly constantly moist climate with precipitations more or less throughout the year, and with a dry season of short duration that is frequently interrupted by showers of rain.

(2.) The Monsoon Forest, or mixed deciduous forest of Indian foresters.

It is more or less leafless during the dry season, especially towards its termination, is tropophilous in churacter, usually less lofty than rain forest: rich in woody lianes and rich in herbaceous, but poor in woody, epiphytes. It is associated with a climate in which a more or less copious rainfall is followed by a well-marked prolonged dry season.

(3.) Savanmah Forest. the open deciduous forest of Indian forester's.

It is more or less leafless during the dry season, and but rarely evergreen, is xemphilous in eharacter, of less height than the two precediug types. bark-like, very poor in underwood, lianes, and epiphytes. and rich in terrestrial herbs, especially grasses. The corresponding climate is one that favours grassland, but not to the extent of excluding tree-growth in a pronounced degree.

(4.) Thorn Forest. - It generally resembles savannah forest, but is cven more xerophilous in character; is very rich in underwood and thorn plants; poor in terrestrial herbs, especially grasses, and usually has no epiphytes. The formation corresponds to a dry climate with an absence of precipitations during the vegetative season of the grasses.

In accordance with transitions between the various climates the abore types are often connected by intermediate forms. The 
commoner transitions are between the savannah forests anỏ Savannalis, the latter being a grassland type very poor in trees, and between thorn forest and open bush or thorny brushwood formations, which latter, in its turn, leads on the Tropical Desert formation.

As a general rule, really successful forests only occur where the annual rainfall is at least 40 inches, and rich luxuriant growth is limited to zones where the annual rainfall is much greater. Where the atmospheric humidity is greater than that of the kind of climate associated with thorn forest, and the amount of rain prespitated during the regetative period of the grasses fluctuates within moderate limits between adjacent localities, pure savannahs alternate with savammah forest. Terophilous woodland becomes established where greater heat and more prolonged rainless periods prevail during the vegetative period, whilst grassland succeeds when a milder temperature and a more even distribution of rainfall prevail during the vegetative season, or a windy dry season is a constant feature of the climate.

In general, with at least 70 inches of rainfall during the year, evergreen high forest prevails; with 58 to 70 inches, mixed deriduous forests; with 35 to 58 inches there is a struggle between xerophilous woodland and grassland. These limits are however, not infrequently departed from, and where the conritions (climatic) are not markedly in favour of any particular type, edaphic influences depending on the character of the soil uften decide the issue. The extensive high forests of Centra! Ashanti and of parts of the Ondo and Illesha Districts of Southern Nigeria, which are not by any means so rerophilous in character as to be classed with the typical monsoon or mixed deciduous forests, and which inhabit regions with an annual rainfall of only 5.5 to 65 inches, are cases in point. Perhaps the greater number of rainy days in the year, a condition characteristic of these extensive well-wooded areas, and a certain tendency in the soil towards swampiness, are responsible for the greener type of forest to be met with there. These regions are, moreover, very hilly, and, in consequence, the air has a higher relative humidity than it would have in the case of forests situated on a lower level. The luxuriant growth is probably accounted for by a combination of all these factors.

With a rainfall of 35 inches and less, xerophilous scrub and, in particular, thorn forest and, thorn bush prevail. If the precipitations are decidedly less than the above, both of these types pass into open scrub. Further reductions still in the annual rainfall lead to the Desert type.

Describing these types somewhat in more detail, especially with respect to their Tropical W $\mathrm{T}$ est African representatives, we hare as characteristics of

\section{A.-The Rain or Moist Tropical Evergreen Forests}

(1.) A poor development of bark on most of the tree stems.

(2.) A less developed branch srstem as compared with that of trees from temperate zones. 
(3.) A profusion of woody lianes, including several species of climbing palms (canes, rattans).

(4.) A large contingent of roody and herbaceous epiphytes that attach themselves to the truuks, branches, and even the extreme tips of the twigs of the forest trees.

(5.) The not infrequent development in several species of trees of "plank buttresses" on the stems, and the formation of cylindrical aerial roots that arise from the stems at some distance from the ground.

(6.) The occurrence of cauliflory, i.e., the formation of flowers from dormant buds in the old wood.

(i.) The presence of numerous epiphyllous epiphytes, such as small mosses, ferns, algæ, \&c., on the leaves of woody plants.

The features described above are common to a greater or less degree to all tropical rain-forests.

In the West African forests of this trpe, such as those found in Southern Nigeria and on the Gold Coast, the woody lianes are represented by various species of Landolphia (L. ovariensis, I. Klainei, and many others), Carpodinus, Clitandra, Strophanthus, Entada scandens, Artobotrys Thomsonii, species of Triaspis, Hippocratea, Lonchocarpus, C'ombretum, Musscenda, and scandent pahms such as Calamus and Ancistrophyllum.

The feebler and more succulent climbers are represented by Aroids of the genera Culcasia, Cercestis, and Raphidophora; they, however, are confined to the stems and larger branches of the trees.

Woody epiphytes are represented by various species of Ficus, aud the smaller herbaceous ones by sereral genera of orchids, the most conspicuous of which are species of Angraecum and Megaclinium.

Several species of ferns are also epiphytic in habit in these forests; the most noticeable belong to the genus Platycerium.

A fairly large number of the forest trees are provided with " plank buttresses." They include all the Khayas (mahoganies), with the exception of Khaya senegalensis from the savannah forests, most of the Pseudocedrelas, the silk-cotton trees Eriodendron anfractuosum and Bombax brevicuspe, TripTochiton .Johnsonii, Heritiera utilis, Piptadenia africana, Antiaris toxicaria, the Offram (Terminalia superba), and many others. The plank buttresses of Heritiera utitis have the peculiarity of separating from the stem of the tree shortly below the level from which they are given off, and in this respect represent an intermediate stage between the cylindrical, aerial " prop roots," and the typical plank buttresses.

The former type of ront is dereloped by the umbrella tree (Musanga Smithii), species of Garcinia, and an unidentified species of small tree known to the natives as the $N^{*}$ Kotan, from the mood of which they prepare charcoal.

Caulifiory occurs in the case of many species of Ficus, Cola cauliflora, and the huge trees of the genus Omphalocarpum, as well as amongst other species. 
The tropical rain forests of the Gold Coast and Southern Nigeria contain trees of very lofty growth scattered amongst those of more moderate dimensions. The outline of the top of the forest regetation is very irregular in shape, and is frequently interrupted by the crowns of these giants, which include the Khayas, Pseudocedrelas, the Odoum (Chlorophora excelsa), the IVau-uaw (Triplochiton Johnsonii), the Offram (Terminatia superba), the silk cotton trees, Eriodendron anfractuosum and Bombax brevicuspe, the Dahomah (Piptadenia africana), and another species of the same genus, the Baku (Mimusops Jjare), which is a reritable giant, Intiaris tovicaria, the gum copal tree (species of Cyanothyrsus), the Biunue (species of Detarium), the incense tree (Santiriopsis Klainei), and the Kolioti (Pynaertia ealaensis).

The other constituents of the forests are represented, amongst many others that have not ret been identified, by the Afram (probably a species of Parinarium), the Emril (species of Terminalia), the Athanah (Pentactethra macrophylla), the Asomah (Parlia species), the Essia (Combretum species), the Awama (RicinodenAron africanus), Tetrapleura Thonningii, Bertinia acuminata, Musanga Smithii, the umbrella tree, Monodora myristica, Monodora tenuifolia, the Afana and Apurro (unidentified, small trees), Toacanga africana, Rauwolfia vornitoria, Alstonia congensis, the silk rubber tree (Funtumia elastica), the Bossè (Guarea species), the Pebedum (Lovoa Klainesnu), Albizsia rhombifolia, the Olisibiri or "Flintwood tree," Myrianthus arboreus, the Kishia (Sarcoeephalus eseulentus), a new species of Afzelia, Heritieva utilis, Allanblaclia floribunda, Distemonanthus Benthamianus, Motandra guineensis, Bertiera montana, Combretum comosum, Diospyros species, Clevodendron violaceum, Mussaenda erythrophylla, species of Heckeldora, C'anarinm Schweinfurthii, C'arpolobia lutea, Usteria guineensis, species of Baphia, Berlinia auriculata, Trichilia species, Pentadesma butyracea, Irvingia Barteri, Acacia pennata, Cynometra Afzelii, Caesalpinia Bonducella, species of Acalypha, Macaranga, and the oil palm, Elaeis guineensis.

As a rule, the trees in the rain forests are connected one with another by a regular network of climbers. Epiphytes are crowded all over the stems and larger branches. Several tiers of regetation corresponding to the heights attained by the component species are to be met with, and under all a deep gloomy shade prevails, relieved only occasionally by spots of sunshine on clearings formed by the downfall of some forest giant. The air is saturated with moisture, and is, as a rule, remarkably still; conditions very favourable to luxuriant forest growth throughout the area inhabited by the rain forests. The dry season is of short duration, is frequently interrupted by showers of rain, and the Harmattan winds are feebly developed.

The virgin forests of this type are as a rule comparatively free of tangled undergrowth. The latter seems to be a secondary development brought about by the destruction of the regetation for farming purposes; in the older forests the undergrowth is straight and not very dense, so that it is possible to walk about in it without having to continually use the knife to clear a way through the forest. 
Quite a large proportion of the trees found in this type have a very wide range, and are to be met with all over extensive tracts of country that possess a climate with a much smaller rainfall; in such areas, howerer, owing to the greater humidity brought about by the hilly nature of the country and the existence of deep sheltered vallers that are frequently occupied by perennial streams and swampy soil, the trees in question are still able to thive, but with many of them the departure in habitat from the continually moist environment of the rain forest is associated with a more pronounced rerophilous habit and a greater periodical defoliation Some species remain evergreen throughout their range.

The following trees are found distributed about the country from the centre of the rain forest region (Lower Tano and Ankobra liver basins) right up to the borders of the savannah forest region in Northern Ashanti.

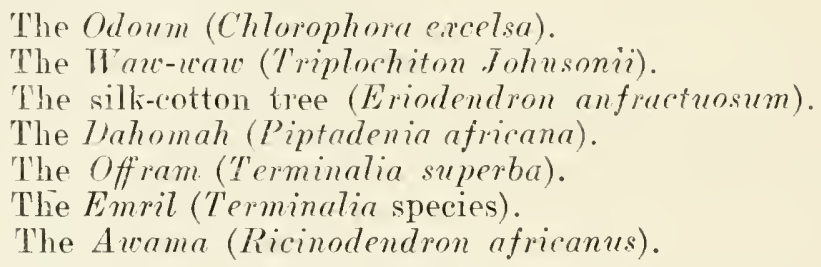

Other species with an almost equally extensive range are invariably associated with the presence of moister soil such as occurs near the beds of streams, edges of swamps and similar collections of water. Their distribution is governed by edaphic influences. and they keep reappearing throughout extensive stretches of country.

Including species that are common to most of the clinatic formations, the more raluable plants from the rain or moist tropical evergreen forests of the Gold Coast and Ashanti are arranged below in accordance with the character and comparative ralue of the products they yield.

(a.) Species yielding first-class timber fit for export to Europe and other countries.

i. Mahoganies.

The Dubini (a new species of Khaya).

ii. Cedars.

The Puntiva or Penkua (Pscudocedrela cylindrica).

The Tiama-Tiama (a new species of Pseudncedrela).

The Bossè (undescribed speries of Guarea).

The Pebedum (Loroa Kilaineana).

All the above trees belong to the natural order Meliacea. The timber of the Pebedum closely resembles teak in colour and structure.

The Odoum (Chlorophora excelsa).

iii. Other species:-

The $N^{\prime}$ yantion (Heritiera utitis).

The Binmè (a lofty species of Detarium). 
The Elhye or incense tree (Boswellia Klaineana?).

The Baku (Mimusops Djave).

(b.) Species yielding good timbers fit for local use.

The Koloti (Pynaertia ealaensis).

The Kishia (Sarcocephalus esculentus).

The Emril (species of Terminalia).

The Dahomah (Piptadenia africana).

Tlie Waw-waw (Triplochiton Johnsonii).

(c.) Species the wood of which is suitabie for the construction of shingles.

The Offram (Terminatia superba).

Another similar tree (Terminalia Brownei).

The Emril (species of Terminalia).

Cordia Irvingii, a tree from the rain forests of the Okwawu hill system.

(d.) Species the stems of which are suitable for mine props.

The Okisibiri or Flint wood tree (an undetermined species).

(e.) Species the fruit of which yields vegetable oils and fats.

The Awama (Ricinodendron africanus).

The Athawah (Pentaclethra macrophylla).

The Baku (Mimusops Djave):

Carapa guianensis.

Irvingia Barteri.

Pentadesma butyracea.

The oil palm (Elaeis guineensis).

From the above list it will be seen that this type of forest is very rich in oil-yielding species.

(f.) Rubber-yielding plants.

i. Good class rubber.

Funtumia elastica (more plentiful in the monsonn forests).

Landolphia Droogmansiana?

Landolphia owariensis.

ii. Inferior rubbers.

Carpodinus hirsuta.

Landolphia Klainei.

Besides species of Clitandra and other kinds of Carpodinus.

(g.) Fibre-yielding plants.

These are represented by small shrubs belonging to the genera Urena, Triumfetta, Hibiscus, \&c., and are weeds that spring up on cleared areas. They are more suitable for cultivation as an agricultural crop.

(h.) Plants yielding dyec.

The Nyi-Na-Kobin (Bombax brevicuspe), the bark of which yields a deep brown-coloured fas:? re.

Note.-The N'rankon is confined to the rain forests of the maritime zone, and is usually not found further inland than about 90 miles from the sea. 


\section{B. The Fresh-water Swamp Forests.}

This is an edaphic formation, and is composed of plants that have adapted themselves to growth in a permanently wet soil. They have much the appearance of plants inhabiting the rain forest, but are not so crowded. The formation is a comparatively open one. 'The swamps occur chiefly in the vicinity of the larger rivers, and are often caused by their overflow. They occur also in hilly country along some of the deeper valleys.

The vegetation most partial to such areas contains, amongst trees, the Kaliu. or red iron wood tree (Lophira procera), the Baya (Mitragyne macrophylla), Macrolobium Palisotii, Macrolobium stipulaceum, Cynometra Afzelii, Cynometra Mannii, P'terocarpus csculentus, the Nyamedua (Alstonia congensis), Treculia africana, and Anthocleista nobilis.

The palms are represented by the bamboo palm, Raphia Tinifera, and Calamus Barteri.

Shrubs by Sarcocephalus Russeggeri, Trophyllum hirtellum, and Anona palustris; water-lilies by $N y m p h a e a$ stellata, and $N$. Lotus; the Amaryllids by Crinum natans, and C. purpurascens.

Orchids by species of aquatic Lissochilus, such as L. longifolius and L. roseus.

The Aroids are represented by the West African "sudd or cabbage weed," Pistia Stratiotes, which often escapes into the streams and seriously interferes with navigation, and by largeleaved species such as Anchomanes dubius and Cyrtosperma senegalense.

A small balsam with pretty red flowers, Impatiens Irvingï, also occurs in the shallower places.

Amongst the trees some species, such as the Kaku and the $N$ yamadua, are often found along the edges of the swamps, and occasionally at a distance from water, but they are always at their best when either growing in the swamps or close to them. During the dry season they are practically defoliated.

In the savannah regions the fresh water swamps are generally fringed by a belt of Mitragyne africana, several species of Crinums, and the fibre plant Honckenya ficifolia. The most valuable species from the swamp formations of the rain forest and monsoon forest districts are :-

\section{For timber-}

The Kaku (Lophira procera), which, so far as is known, furnishes the most durable timber of the West Coast. As a fuel the wood has very high calorific properties. It is confined to the maritime zone.

The Baya (Mitragyne maciophylla) also vields a good timber that is said to have been exported to Europe as mahogany.

\section{Fibres-}

The valuable Piassava fibre is prepared from the rachis of the leaves of the bamboo or tombo palm, Raphia vinifera. 
Another good long fibre is yielded by the plant Honckenya ficifolia.

The seeds of Lophira procera are rich in vegetable oils.

\section{The Monsoon or Mixed Deciduous Forests.}

This is a formation that is very rich in plants of economic importance. It is inhabited by both Tropophilous and Hygrophilous plants in varying proportions, according to local fluctuations in the rainfall and edaphic conditions. The forests, on the whole, are greener than the typical monsoon forests of India, Burma, and Siam, and contain fewer species with the Tropophilous habit; nevertheless, owing to the complete, or nearly complete, defoliation of the latter during the dry season the West African type is easily distinguished at that season of the year from the true rain or moist tropical evergreen forests. Forests exactly similar in habit to the mixed deciduous forests of Eastern Asia are, as far as my experience goes, very rarely met with, and then only as insignificant belts in, tropical West Africa.

The Indian formation is more closely approached, on the other hand, by the denser stocked saramnah forests of this coast, but here the grasses form a more prominent feature of the formation than occurs in the case of the Indian type with which I am comparing it. Generally speaking, in Tropical West Africa the transition between the rain forests and the savannah forests is more abrupt than it is in those parts of Asia with which I am acquainted. This is probably accounted for by the prolonged dry season experienced over extensive areas in the former continent, whereas, on the Gold Coast and in Southern Nigeria, up to the $8^{\circ}$ parallel of north latitude at all events, that season is tempered by frequent showers of rain during the tornado months which coincide with the regetative periods of the grasses, and thus favours them at the expense of forest growth. In other words, owing to this feature of the climate, as soon as an area becomes, from the reduction in the annual rainfall, unsuitable for luxuriant forest growth, it is appropriated by the grasses instead of by the intermediate stage represented by the typical monsoon forests.

Perhaps good examples of the latter occur in the drier portions of the Northern Territories and Northern Nigeria.

A large number of the evergreens found in the mixed deciluous forests of the Gold Coast belong identically to the same species as those met with in the rain forest. They are, however, generally found growing in the moist soils close to the banks of streams, or in sheltered ravines, and on the northern aspects of the hills, whilst the deciduous-leafed speries occupy mainly the drier soils further back from the streams and the exposed southern and western aspects of the hills. The mixture of Tropophilous with Hygrophilous species is more one of groups of each type than of a true intermingling of individual trees of each kind.

It may be that the more pronounced, dry Harmattan winds met with in the higher latitudes (from $7^{\circ} 30^{\prime} \mathrm{N}$, and upwards) during 
the winter months (November to February), which is the resting season of the grasses (a period when they are absolutely indifferent to drought), and the prevalence of fierce fires at the same time, severely handicaps the woodland formations in their struggle with the grasses.

A peculiarity of the West African monsoon forests is the frequent occurrence in them of small but pure communities of herbaceous plants belonging to the order Scitamineae. Such patches are composed of species of Amomum, Costus, and Phrynium, the last of which supplies the natives with leares for thatching purposes, and the first mentioned genus a species that yields "the grains of Paradise." Each such patch is pure, and consists practically of one species.

The mixed deciduous forests of the Gold Coast and Ashanti, besides containing to a greater or less extent most of the valuable species whose headquarters are the rain forests, and which have been referred to when describing the latter formation, is composed of the following plants, amongst others, that have not yet been identified or named.

The Anonacere are represented by-

Monodora brevipes; a small tree.

Hexalobus grandifolia; a large tree.

Xylopia parviflora; small tree.

Xylopia aethiopica; a small tree.

The Bixinece by-

Oncoba dentata; a shrub or small tree.

Oncoba spinosa; a shrub.

The Hypericinea by-

Haronga madagascariensis; tall shrub.

The Malvacece by-

Many species of Sida, Urena, and Hibiscus.

The Bombacea by-

Eriodendron anfractuosum; a large tree.

The Sterculiacea by-

Sterculia cordifolia; a large tree.

Sterculia tomentosa; a medium-sized tree.

Sterculia Barteri; a large tree.

Sterculia tragacantha; a tree.

Cola laurifolia; a small tree.

Cola Afzelii; a small tree.

The Tiliacere by-

Grevia carpinifolia; a shrub.

Glyphoca grewioides; a shrub.

And species of Triumfetta.

The Malpighiacea by-

Flabellaria paniculata; a climber.

Acridocarpus Smeathmanii; a climber.

Heteropterys africana; a shrub.

The Rutacece by-

Xanthoxylum senegalense; a tree, 
The Simarubece by-

Harrisonia abysinica; a shrub.

'The Meliacea by--

Khaya anthotheca; a large timber tree.

Khaya grandis; ditto.

Khaya Punchii; ditto.

Pseudocedrela utilis; ditto.

Carapa guianensis; a small tree.

The Olacinea by-

Ximenia americana; a shrub.

A podytes beninensis; a shrub.

The Sapindacea by-

Lecaniodiscus cupanioides; a small tree.

Paullinia pinnata; a shrub.

Deinbollia insignis; a tree.

The Anacardiacew by-

Spondias lutea; a large tree.

Pseudospondias microcarpa; a tree.

The Connaracea by-

Cnestis ferruginea; a shrub.

The Leguminosea by-

Pterocarpus esculentus; a tree found near water.

Berlinia acuminata; a medium-sized tree.

Afzelia africana; a tree.

Albizzia fastigiata; a tree.

Albizzia Brownei; a tree.

Cassia fistula; a tree.

Millettia Thonningii; a shrub.

Cynometra species, close to $C$. Mannii; a tree found near rivers.

Lonchocarpus sericeus; a small tree.

Lonchocarpus cyanescens; a small tree.

Acacia ataxacantha; a scrambler.

Dialium guineense; a medium-sized tree.

Erythrina tomentosa; a tree.

Mimosa asperata; a shrub.

Piptadenia africana; a large tree.

Xylia Evansii; a tree.

Afrormosia laxiflora; a large tree.

The Rosacece by-

Parinarium robustum; a tree, and

Another species.

The Combretacea by-

Quisqualis indica; a climber.

Combretum Zenkeri; a shrub.

Combretum racemosum; a climbing shrub.

Terminalia superba; a tree.

Terminalia Brownei; a tree, and the

Emril, another species of Terminalia. 
The Rubiacea by-

Morelia senegalensis; a shrub.

Macrosphyra longistyla; a scaudent shrub.

Pavetta Baconia; a shrub or scandent shrub.

Cremaspora africana; a shrub.

Morinda citrifolia; a tree.

Morinda longiflora; a shrub.

Oxyanthus tubiflorus; a shrub.

Randia muculata; a shrub.

Musscenda tenuifora; a shrub.

Musscenda splendeus; a scrambler.

Musscenda erythrophylla; a scrambler.

The Sapotacere by-

Mimusops multinerris; a tree.

Chrysophyllum albidum; a tree.

The Apocynacere by-

Polyadoa umbellata; a small tree.

Holarrlena Wulfsburgii; medium-sized tree.

Funtumia elastica; a tree.

Funtumia africana; a tree.

Strophanthus hispidus; a climber.

Strophanthus sarmentosus; a trailer.

Strophanthus Preussii; a climber.

strophanthus gratus; an erect or climbing shrub.

CTitandra togolana; a climber.

Carpodinus hirsuta; a robust climber

C'arpodinus fulva; ditto.

C'arpodinus Barteri; a climber.

Landolphia owariensis; ditto.

Landolphia scandens; ditto.

Landolphia Thompsonii; ditto.

Landolphia florida; ditto.

Pleioceras Barteri; low shrub.

Callichitia Barteri; a small shrub.

Alafia Barteri; ditto.

Alafia landolplioides; a climber.

Toacanga africana; a shrub or small tree.

The Asclepiadere by-

Kamahia consimilis; a shrub; grown near water.

'The Bignoniacere by-

Spathodea companulatu; a tree.

The Acanthacea by-

Acanthus montana; a shrub.

The Verbenacere by--

Lantana camara; a shrub.

Lippia adoensis; a shrub.

Clerodendron splendens; a shrub.

And many others of the same genus.

The Urticacea by-

Chlorophora excelsa; a huge timber tree.

Ficus Vogelii; a tree: and many others of the same genus.

Myrianthus arboreus; a small tree. 
The Celastrucece by-

Hippocratea Welwitschii; a climber.

The Ebenacec by-

Diospyros mespiliformis; a large tree.

Diospyros monbuttensis; a tree.

The Myrtacece by-

Napoleona Voyelii; a small tree.

The Passiflorea by-

Smeathmannia pubescens; a shrub.

The Piperacea by-

Peperomia Vogelii; a herb.

The Palme by-

Elaeis guineensis; a tree.

Raphia vinifera; a tree.

$\left.\begin{array}{l}\text { Calamus species. } \\ \text { Ancistrophyllum species. }\end{array}\right\}$ scandent palms.

The Aroidece by-

Several species of Amorphophallus.

Anchomanes Hookeri; a herb, and

Others of the same genus.

'The Dioscoreacea by-

Dioscorea prehensilis.

Dioscorea Preussii.

Dioscorea alata and others.

The Liliacere by-

Dracaena maculata and others.

Sansevieria guineensis.

The Scitaminea by-

Amomum Melegueta.

Amomum latifolium.

Amomum Danielli.

Phrynium Benthami.

Phrynium brachystacliys.

Phrynium Danielli.

Costus afer.

And the Amaryllidea by speries of Crimum and Hamanthus.

Some of the trees common to the rain forests and the monsoon ones reach their optimum devolopment both in growth and numbers in the latter formation. This is most marked in the case of the following specres:-

The Waw-waw (Triplochiton Johnsonii).

The Dahomah (P'iptadenia africana).

The Offram (Terminalia superba).

The Emril (Terminalia species).

The Awama (Ricinodendron africanus).

The silk rubber tree (Funtumia elastica).

The Duakobin (Afrornosia laxiflora).

They are not only more abundant in this type, but they actually become somewhere or other within it the dominant species. 
Each of the above species has within its distributional range a particular area or series of areas in which it is at its optimum and aggressively dominant.

As a general rule the undergrowth in the drier portions of the monsoon forests is less dense than it is in the case of the rain forests, and the number of tiers of vegetation is also reduced.

The more valuable economic species to be met with in the monsoon forests may be arranged as shown below.

(a.) Species yielding first-class tumber fit for export.

i. Maloganies-

'The white mahogany (Khaya anthotheca).

The large-leafed mahogany (Khaya grandis).

Mr. Punch's mahogany (Kihaya Punchii).

In addition to these the Dubini (a new species of Khaya) from the rain forests is also frequently met with in the moister portious of the monsoon forests.

ii. Cedars-

Pseudocedrela utilis, the Effuokonkonti of the Ashantis, a grigantic species, as well as the Tiama-Tiama from the rain forests.

iii. Other species-

The Odoum (Chlorophora excelsa).

Mimusops multinervis.

The Dua-Kobin (Afrormosia laxiflora), which yields a very pretty yellow coloured satin-wood that has, when figured, sold for very high prices in Liverpool. So far it has only been exported (on a small scale) from Southern Nigeria.

The ebony tree (Diospyros mespiliformis).

(b.) Species yielding good timber fit for local use.

The Waw-waw (Triplochiton Johnsonii).

The Dahomah (Piptadenia africana).

Xanthoxylum senegalense, vields a yellow wood.

The Emril (Terminalia species).

The Papoa (Afzelia africana).

Albizzia fastigiata.

Albizzia Brownei.

Xylia Evansii.

Parinarium robustum.

(c.) Species the wood of which is suitable for making shingles.

The Offram (Terminalia superba).

The Emril (Termmalia species).

Terminalia Browner.

(d.) Species the fruit of which yield vegetuble oils and futs.

The oil palm (Elceis guineensis).

The Awama (Ricinodendron africanus).

Carapa guianensis.

(e.) Rubber-yielding plants.

Funtumia elastica. Most plentiful in this type of forest.

Landolphia owariensis.

Landolphia Thompsonii.

Landolplica forida.

Landolphia scandens.

Carpodinus hirsuta.

Ficus Vogelii, yields a fair quality rubber. 
(f.) Fibre plants.

In addition to the various species of Urena, Triumfetta, Sida, Hibiscus, \&e., that are herbaceous and suitable more for cultivation as agricultural crops than as forest ones, the following two trees yield very good fibres :-

Sterculia Barteri (from the bast).

Raphia vinifera.

(g.) Dyes.

Indigo is obtained from Lonchocarpus cyanescens.

'The above list shows how rich the monsoon forests are in valuable species. Doubtless many more will be discovered as the forests get better known.

On the whole the age gradations of the timber trees in this type are more satisfactorily represented than they are in the rain forests.

The species most characteristic of the monsoon forests are :Sterculia cordifolia.

Sterculia Barteri.

Sterculia tomentosa.

Cola Afzelii.

Spondias lutea.

Albizzia fastigiata.

Cassia fistula.

Lonchocarpus cyanescens.

Erythrina tomentosa.

A frormosia laxiflora.

Dialium guineense, \&c., \&c.

'Their occurrence anywhere is a certain index that the climate of that locality corresponds to the requirements of the monsoon forests.

\section{The Savannah Forests.}

This in brief is a park-like formation, rich in terrestrial herbs and more particularly in grasses. The tree growth is represented by arboreal tropophytes and evergreen serophytes, but the latter are not numerous, and form an insignificant proportion of the vegetation. The density of stock, so far as the trees are concerned, varies in accordance with the nature of the soil and its telluric properties. On stiff laterite formations the trees are dwarfed, gnarled, and widely scattered, whilst alluvial hollows and the narrower valleys are much more densely stocked, but never to the extent seen in the monsoon or mixed deciduous forests. Where the supply of telluric moisture is copious, however, fringing forests of great density occupy the soil, and they frequently contain species characteristic of the monsoon and even of the rain forests. The outcrops of laterite and metamorphic rocks so frequently met with in Northern Ashanti and in the Hinterland of Southern Nigeria are usually encircled by a ring of such fringing vegetation, the moisture in the soil bordering the outcrops of rock being supplied from the drainage off the latter. A peculiarity of the country occupied by the savannah forests is that during the rainy season extensive areas are under water for 
very long periods at a stretch; but they rapidly dry up at the end of the rains, and the soil is then thoroughly turned over by the action of the earth-worms. Literally hundreds of thousands of the latter must operate within the space of a few acres, for the surface of the soil is often for many square miles in succession absolutely covered with their custings. These, when dry and hard, render the act of walking over them a very fatiguing operation.

In such areas an impermeable pan of hard clay or sometimes of laterite rocks exists close to the surface of the soil and renders the latter swampy.

Another feature of the savannah forests is the annual prevalence in them, early in the dry season, of fierce grass fires that do all incalculable amount of harm to tree growth and keep it in check. The fires are generally most intense and destructive on the driedup swampy areas which are, as a rule, covered with tall, coarsf grasses belonging to the family Panicece.

A high proportion of the trees possess a very strongly developed protective layer of bark on their stems and branches, and this is not unfrequently accompanied by a corresponding increase in the thickness of their root system; in fact the latter is sometimes monstrous in its development. 'These appear to be contrivances to guard the trees against damage from the fires, as well as adaptations to a xerophytic climate.

The average height of the tree vegetation is much less than that characteristic of the monsoon, rain, and fringing forests, but occasionally gigantic specimens of the Odoum (Chlorophora excelsa), the silk cotton tree (Eriodendron anfractuosum), and the baobab (Adansonia digitata) are to be met with in the savannah forests.

The vegetation of the latter is very characteristic, and is enumerated below :-

The Anonacew are represented by-

The wild custard apple (Anona senegalensis), a woody shrub.

The Papaveracea by-

Argemone mexicana; a weed.

The Capparidacea by-

A species of Capparis.

Cleome ciliata

Gynandropsis pentaphylla $\}$ Tropical weeds.

'The Bixinea by-

Cochlospermum tinctorium; a characteristic shrub of this formation.

The Hypericinea by-

Species of Psorospermum; shrubs and trees.

The Malvacee by-

Various species of Sida, Urena, and Hibiscus. 'They are all weeds yielding good fibres. A species of the last genus (H. lunarifolius) is the best fibre-yielding plant amongst them, and is sometimes cultivated by the natires. 
The Sterculiacew by-

Cola cordifolia, a tree.

'The Tiliacea by-

Species of Triumfetta and Honckenya ficifolia; fibreyielding weeds and shrubs.

The Bombacee by-

Adansonia digitata, the baobab tree; fruit edible and wood rich in fibres.

The silk cotton tree (Eriodendron anfractuosum).

'The Meliacew by-

Khaya senegalensis, the Senegal mahogany. Grows to a medium-sized tree.

Pseudocedrelo Kotschyi, a medium-sized tree.

The Ampelidece by-

Species of Leea.

The Leguminose by-

The Senegal rosewood tree (Pterocarpus erinaceus).

Erythrina senegolensis; a shrub or small tree.

The "sass-wood" tree (Erythrophloeum guineense).

The "locust bean" tree (Parkia filicoidea).

Albizzia angolensis, a tree.

Afzelia africana, a tree.

Detarium senegalense, a tree.

Entada soudanica, a small tree.

Entada abyssinica, a small tree.

Dichrostochys nutans, a small tree.

Ormosia laxiflora, a small tree.

Mezoneurom Benthamianum, a shrub.

Bauhinia reticulata, a shrub.

Daniella thurifera, the "balsam copaiba tree."

Acacia Sieberiana, a tree.

Acacia Catechu (Willd.), the "cutch tree"; and another species close to $A$. nigrescens.

Tamarindus indica, the Indian tamarind.

In addition to the above there are various herbs belonging to the genera Indigofera, Tephrosia, Crotalaria, and Cassia.

The Rosacece by-

Parinarium polyandrum, a small tree.

Parinarium curatellifolium, a small tree.

P'arinarium Mobola, a small tree.

The Combretacece by-

Anogeissus leiocarpus, the "chew-stick" tree.

Terminalia macroptera, a tree.

Terminalia togoensis, a tree.

The Myrtacece by-

Eugenia owariensis, a small tree.

The Rubiacea by-

Crossopteryx Rotschyana, a small tree.

Randia malleifera, a shrub or small tree. tree.

Gardenia sp., probably $G$. ternifolia, a shrub or small 
Surcocephalus esculentus, a dwarf form of the rain forest tree (?)

Species of Oldenlandia; all herbs.

The Composite by-

Numerous herbs and weeds.

'The Apocynacea by-

A xerophilous form of Landolphia owariensis which has acquired a shrubby habit. It is rather rare.

C'arissa edulis, a shrub.

The Sapotacea by-

The shea butter tree (Butyrospermum Parkii).

The Bignoniacee by-

Kigelia pinnata, the "sausage tree."

'The Rhamnacew by-

Zizyphus mucronata and another species.

'The Verbenacea by-

Vitex megaphylla, a tres.

Vitex cuneata, a tree.

The Urticacea by-

(?) Ficus asperifolia, and others.

The Euphorbiacea by-

A species of Excoecaria, a shrub or small tree.

Bridelia micrantha, a shrub or small tree.

Phyllanthus reticulatus.

Antidesma venosum, a small tree.

Species of Hymenocardia.

The Jipterocarpea: by-

Lophira alata, a tree.

The Loganiacea by-

Strychnos emarginata and others.

The Palmce by-

Borassus flabelliformis var. athiopica.

The Doum or Fan Palm.

Phonix reclinata, the wild date palm.

The Liliacea by-

Asparagus Pauti-Guitelmi; climbing shrub.

Asparagus africanus; scrambling shrub.

Aloe Barteri.

Gloriosa virescens; a climber.

'The Smilacere by-

Smilax Kraussiana, a trailer.

The Orchidacere by-

Several species of Lissochilus, amongst which L. roseus and

L. Heudelotii may be mentioned.

The Amaryllidere by-

Crinum giganteum and others.

Haemanthus species.

Hymenocallis senegambica.

The Cyperacea by many genera aut species, including Bulbostylis barbata and B. laniceps. 
The Graminea by a large number of genera, amongst which the following may be mentioned-

Eragrostis, Andropogon, Punicum, and the bamboo Uxytenanthera abyssinica.

Amongst the more useful plants of the savannah forests the following may be mentioned :-

(a.) Timber trees.

Afzelia africana, the Opapoa of the Aquapim natives. Yields a first-class durable timber, and is often the dominant tree in some of the savamahs.

Daniella thurifera, the balsam copaiba tree. The wood is impregnated with a resin, but it is a useful timber.

Detarium senegalense. Yields excellent timber.

Khaya senegalensis, the Senegal mahogany. Does not reach a great size; timber of first-class quality.

Pseudocedrela Kotschyi, the dry country cedar. Tields a beautiful timber.

Erythrophloeum guineensis. Grows into a fine spreading tree. Wood hard and durable.

Lophira alata. Good wood, but usually of small dimension.

Pterocarpus erinaceus, the Senegal rosewood tree.

Tamarindus indica. Yields an ornamental wood.

The palm, Borassus flabelliformis, the wood of which, exclusive of the pith, is extremely durable.

(b.) Trees the fruits of which are rich in vegetable oils.

The shea butter tree, Butyrospermum Parkii; extremely abundant.

The so-called “ African Oak," Lophira procera.

(c.) Fibre-yielding plants.

Various species of Urena, Triumfetta, Hibiscus, and the woody shrub or small tree, Bauhinia reticulata, the bast fibres of which are long and very tough.

The wood fibres of the huge baobab tree, Adansonia digitata, are also of commercial value, and are from time to time exporteri to Europe from Senegal.

(d.) Wooc̉ oil.

This is yielded by the "Balsam Copaiba tree."

(e.) Gums.

By Acacia Sieberiana, Khaya senegalensis, and Anogeissus leiocarpus. They are, however, of but little commercial ralue.

(f.) Dyes.

Infusions of the bark of Bridelia micrantha yjeld a deep reddish-brown dye.

(g.) Mordants.

The ashes of Anogeissus leiocarpus are used by the natives for that purpose. The wood and bark of this sjecies is also fairly rich in tannin.

(h.) Kubber.

By the dry country form of Landolphia ovariensis. 
In addition to the above the numerous fringing forests found scattered about this formation are rich in valuable plants from the monsoon and rain forests. 'The plants most commonly met with, especially along the banks of the more important streams, are:-Carapa guianensis, which here attains fairly large dimensions, Ricinodendron africanus, a species of Cynometra close to C. Mannii, Pterocarpus esculentus, Mimusops multinervis, Diospyros mespiliformis, Polyadoa umbellata, Sclerebera golungensis, Sterculia Barteri, Sterculia tomentosa, Sterculia cordifolia, Chlorophora excelsa, Khaya Punchii, Khaya grandis, Eriodendron anfractuosum, Cola Afzelii, Xanthoxylum senegalense, Spondias Tutea, Terminalia superba, Albizzia Brownei, Albizzia fastigiata, Spathodca campanulata, the moist country form of Landolphia owariensis, Landolphia Thompsonii, Landolphia florida, Carpodinus hirsuta, the bamboo palm, Raphia vinifera, and the oil palm.

Taken all round, the savannah forests, together with the fringing forests, are fairly rich in useful plants, and since they cover very extensive areas in the hinterland of our West African possessions, they are by no means to be despised. As a general rule the natural regeneration of the trees is good and the age gradations satisfactory.

\section{E. Suvannahs.}

These consist of formations in which trees are practically absent and the dominant growth represented by the grasses. In the portions of West Africa with which I am aequainted they occur merely as local variants here and there of the savannah forests. I have seen no very extensive examples of them.

The thorn forests are also poorly represented and only occur in small patches, such as near Accra, and again in the Banda country of north-western Ashant, within the savamnah forest districts.

The most important of the Edaphic formations is the Mangrove Forest. It is not, however, very strongly represented on the Gold Coast, but in the Niger delta several thousand square miles of country are occupied hy this type. The species composing these forests are very gregarious, and are mainly composed of Rhizophora racemosa, R. Mangle, and Avicenmia africanc. The first two yield excellent firewood, and their bark contains a high percentage of tannin. The timber is hard and fairly durable. The maugrove forests occur at the mouths of the Tano, Ankobra, and Pra Rivere of the Gold Coast.

\section{Conversions.}

As a general rule the destruction of the regetation by the natives for agricultural purposes results in the following conversions, which invariably end in a drier type of vegetation succeeding the one removed. The stages are: Rain forest is converted into monsoon forest; monsoon forest into sarannạh forest: savannah forest into pure savannah, 


\section{Distribution.}

Only a general idea can be given of the distribution of these various types of forest within the limits of the Gold Coast and Ashanti. Accurate data for the preparation of a proper stock map would take years to collect; at present only rough approximations are possible.

The rain or moist evergreen tropical forests are in their typical form restricted on the coast line to the extreme south-west corner of the Colony in the neighbourhood of Axim. From there they extend northwards (with one marked break) along the valleys of the 'Tano, Ankobra, and Bia Rivers, through Wassaw, upper Denkira, and Sefwi, to just north of the seventh parallel of north latitude. They have a tendency to hug the western frontier during the greater portion of their range, and are interrupted between Asankagwa and TViawuso by a broad belt of regetation that possesses a drier strain and stretches across the country from the Tano River to the railway between the station of Imbrahim and a point a few miles south of Oboase. An extensive branch of the rain forest stretches from dxim in a north-easterly direction to Tarkwa, and the Pra River follows the valley of the latter a considerable distance inland, more especially along the upper course of its principal feeders the Anum and Birrim Rivers, and finally splits up into several detached belts occupying the deeper valleys of the Bompata, Abetifi-Obo, Bogora, and Kyebi hill systems.

The savannah forests, on the other hand, together with patches of scrub forest, are well represented along the opposite end of the coast line, viz., on the south-east sea-board, whence they extend in a gradually rlecreasing (narrowing) belt as far west as Sekondi. To the north of Acera ther follow the plain and occupy the country up to the foot of the hills, and then sweeping round to the north-still keeping away from the more pronounced hill systems-follow the valley of the Tolta River and gradually hroaden out till, at latitude $6^{\circ} 30^{\prime} \mathrm{N}$. approximately, they rapidly increase in area, and bending away to the north-west, occupy the whole of the northerm half of Ashanti (from east to west) right up to the Volta River, its large feeder, the Black Volta, and practically the whole of the Northern Territories on the opposite bank. They extend southwards as far as Puliamo on the west, and the neighbourhood of Chichewere in the centre (due north of Kumasi), and Ahetifi further eastwards.

The whole of the country not occupied by either the rain forests or the savannah forests is clothed with a rather green type of monsoon or mixed deciduous forest. The latter is, however, in the more hilly and well watered localities frequently interrupted by narrow belts of evergreen (rain) forest. No very sharp lines of demarcation exist between these types, and they usually merge into each other very gradually. An abrupt transition, however. exists just to the north of Abetifi, where one practically steps out from the moist forests of the hills on to the savannal forests of the Afram plains.

As far as it can he ascertained from data available. the distribution of these various types follows closely that of the climates 
characteristic of such plant formation. The correspondence of the extremes of climate with the extreme forms of vegetation is quite evident enough, as can be seen in the case of the rain forests, the savannah forests, and the thorn scrub; but the agreement is not so pronounced in the case of the intermediate conditions corresponding to the monsoon or mixed deciduous forests. In the district occupied by the latter alternations of narrow belts or small patches of rain forest with vegetation of a somewhat drier character, or with formations approximating closely to the typical monsoon forests, are frequently to be met with next door to each other, but this want of homogeneity is hrought about first by the hilly nature of the country, and secondly by edaphic influences, which become more pronounced in regions where the atmospheric precipitations are not heary enough to support the typical rain forests. The monsoon or mixed deciduous forests correspond to an unstable climate, the factors of which are such as not to decidedly farour either one or the other of the extreme forms of forest vegetation.

The attached sketch map (taken from the Gold Coast annual report of 1907) shows approximately the distribution of the various types of formations mentioned above.

\section{Exports of Forest Produce from the Gold Coast and Ashanti.}

The quantity of forest produce exported from the Gold Coast and Ashanti for the twenty years, $18 S 8$ to 1907 , together with its value, is shown in the attached table, which has been prepared from information given in the Gold Coast Civil List and the annual reports of the Colony.

The average annual output of such produce and its value, calculated from the mean of twenty years, is also given.

The figures show that the mean annual value of the forest produce exported amounts to $£ 576,942$, or considerably over half a million pounds sterling. There is no doubt that the trade in these products is capable of very considerable development, especially in the case of timber and palm oil.

With the opening up of the Tano and Pra Rivers to timber exploitation, by the removal of the obstructions in those streams, the forests are quite capable of more than quadrupling the present output of timber. Similarly there are vast areas in the Waw-saw, Denkira, and Sefwi districts, as well as in Ashanti, which are very rich in the oil palm, and practically untouched at present. In fact, the inhabitants are often so indifferent to the value of the tree that they frequently tap it for palm wine.

With a view to giving some indication of the potential timber wealth of the Gold Coast and Ashanti, the following estimate, based on very low figures indeed, has been prepared.

As timber can, under existing conditions, be extracted profitably only if the length of drag from the forest to the nearest stream capable of floating logs does not exceed three miles, that distance may be taken as the extreme width on either side of the 


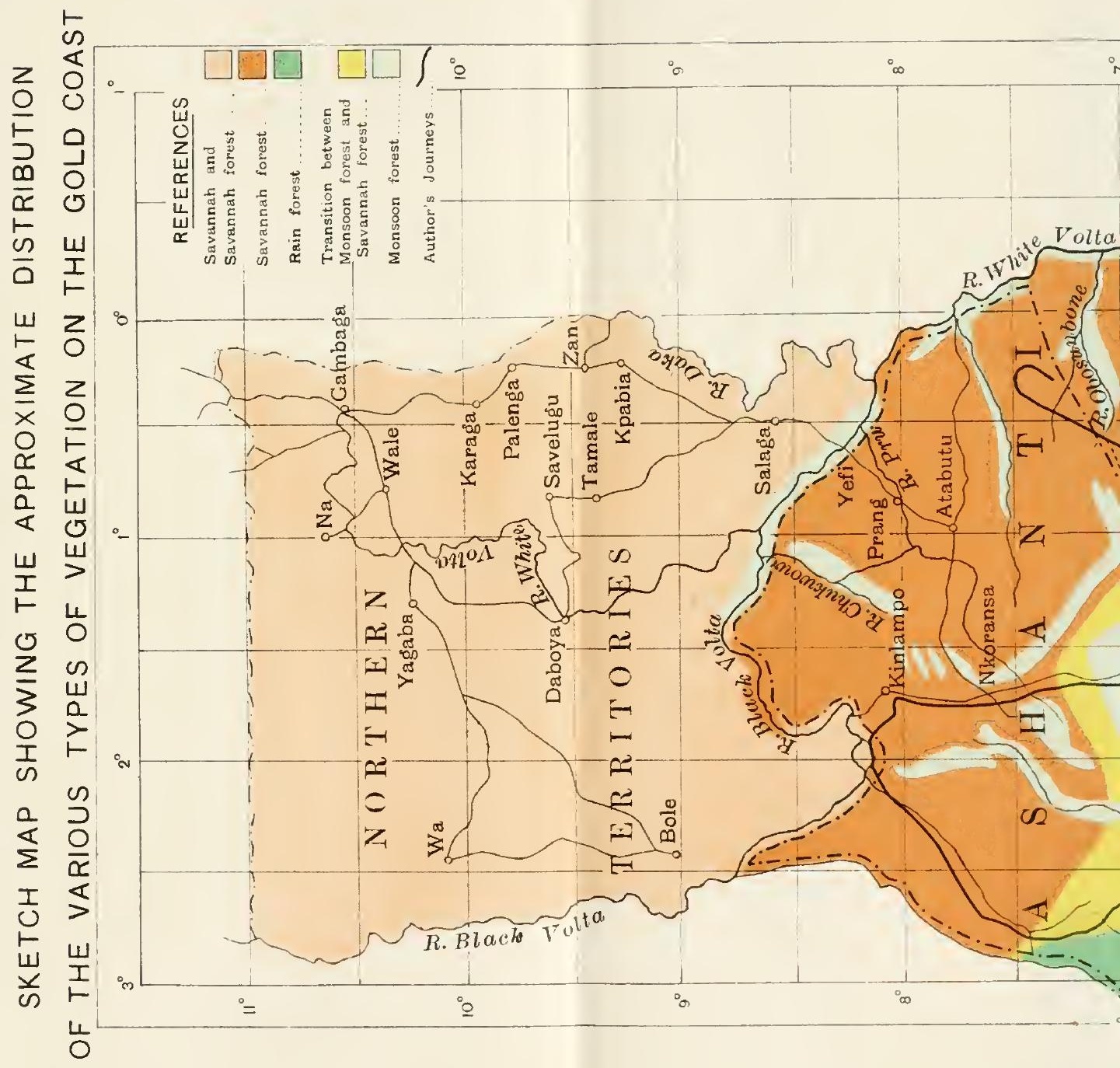




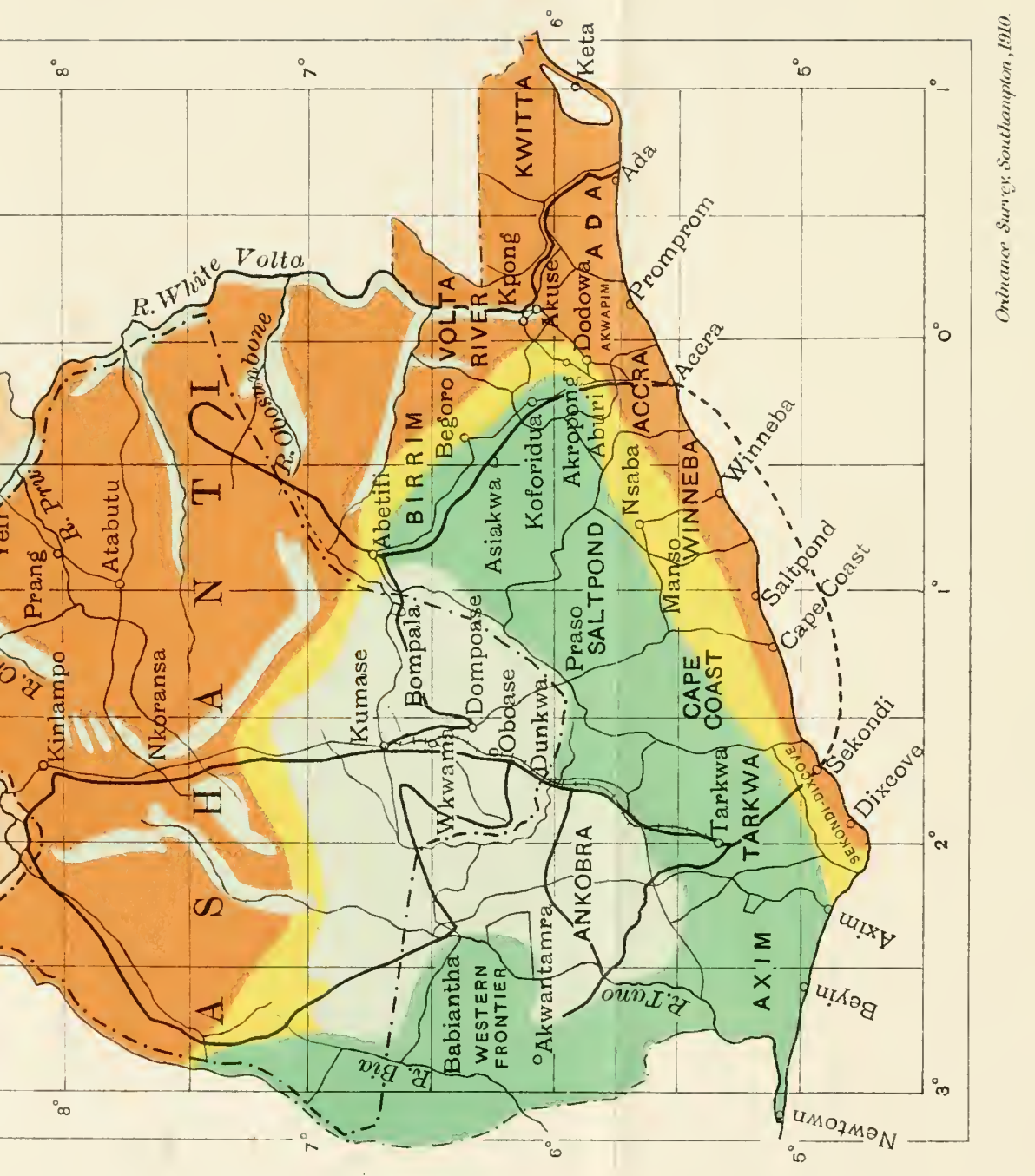




\begin{tabular}{|c|c|c|c|c|}
\hline \multirow{2}{*}{ 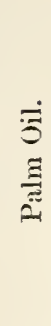 } & $\stackrel{\stackrel{\varrho}{\Xi}}{\stackrel{\Xi}{ٍ}}$ & 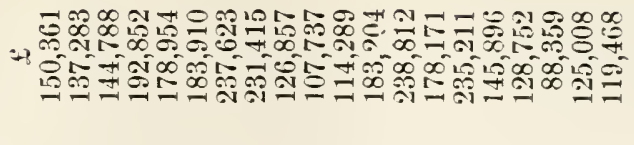 & 章 & 告 \\
\hline & 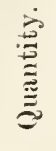 & 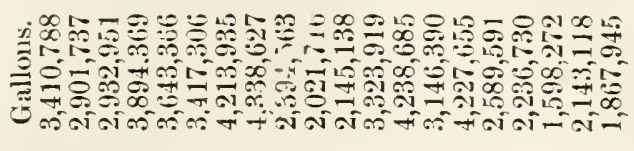 & $\begin{array}{l}0 \\
\infty \\
0 \\
0 \\
0 \\
0 \\
0 \\
0\end{array}$ & 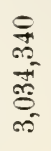 \\
\hline \multirow{2}{*}{ 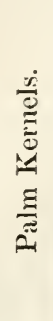 } & 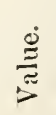 & 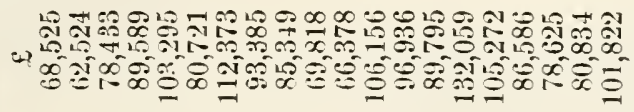 & 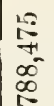 & 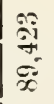 \\
\hline & 离 & 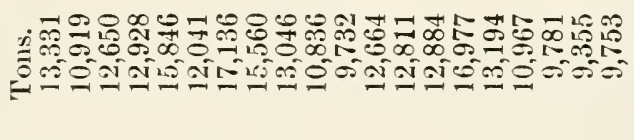 & Z & 勇 \\
\hline \multirow{2}{*}{$\stackrel{\mathscr{D}}{\mathscr{E}}$} & 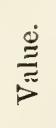 & 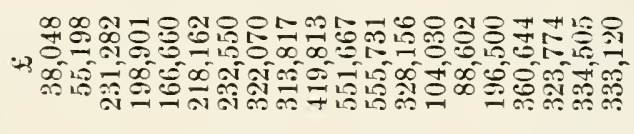 & 焉 & 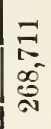 \\
\hline & 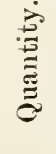 & 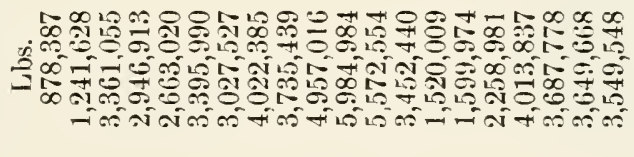 & 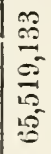 & 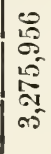 \\
\hline \multirow{2}{*}{ 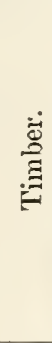 } & $\underset{⿱ 乛}{\stackrel{0}{J}}$ & 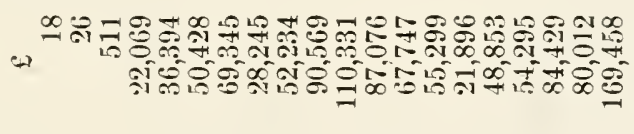 & : & $\mid \begin{array}{l}5 \\
0 \\
0 \\
0\end{array}$ \\
\hline & 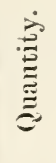 & 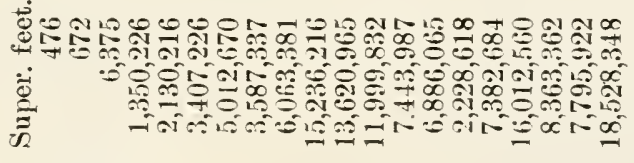 & 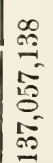 & 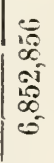 \\
\hline & & 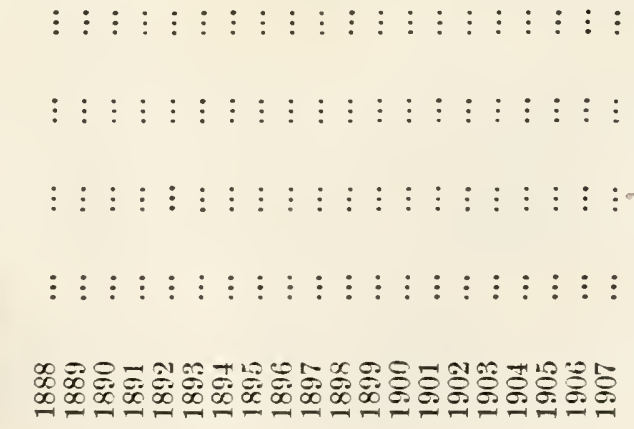 & 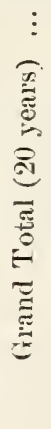 & 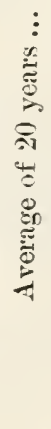 \\
\hline
\end{tabular}


floating streams and railways to which exploitation can extend. Again, the proportion of one mahogany and one cedar tree to every five acres may be accepted as a safe figure to go on. It is in all probability rather less than the actual proportion found in the forests. Taking the railways first, the area available for exploitation with human labour as the hauling power is as follows:-

$$
\begin{array}{r}
\text { Distance from Sekondi to Kumasi }=168 \text { miles. } \\
,, \quad \text { Tarkwa to Prestea }=25 \text { ", } \\
\text { Total }=\overline{193} \text { miles. }
\end{array}
$$

Consequently exploitable area $=193 \times 6$ square miles

$$
=1,158 \text { square miles. }
$$

Deduct $25 \%$ for clearings, farms, \&c. $=-289 \quad,, \quad$,

$$
\text { Total }=\overline{869} \quad, \quad, \quad,
$$

This area at the rate of one mahogany tree for every five acres, or 128 trees to the square mile, will contain $128 \times 869=111,232$ mahogany trees. And as the same number of cedar trees per square mile may also be assumed to exist, the total number of mahoganies and cedars arailable for felling will be twice the number given for mahogany, or $222,46+$ trees. Deduct from this 25 per cent. of the trees to provide for unsound, crooked, or otherwise defectice trees, and we are left with a balance of $222,464-$ 55,616 or 166,848 trees.

Now assuming that it takes thirty years for all the trees now between 10 and 12 feet in girth to reach the latter size, then the number of trees ( 12 feet and orer in girth) that should be felled each year amounts to $10.6,8+8$ trees, or 5,561 trees, which, on the assumption that one tree vields three logs, amounts to an ammul ontput of 16,683 logs.

Similarly the timber from the basins of the Lano, Ankohra, and Pra Rivers may be estimated as follows:-

Exploitable area on Tano and its larger feeders

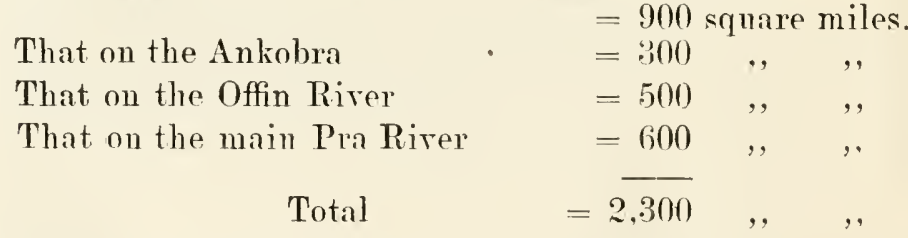

And the number of mahogany and cerlar trees on this area may be computed at $2,300 \times 128 \times 2$ trees $=588,800$ trees. Derheting 25 per cent. for defective trees, the number left for felling amounts to 441,600 trees. Hence, the annual outpnt will equal $4+\frac{1}{30}, 600$ trees $=14,720$ trees or 44,160 logs.

Therefore, the total output from both railways and streams shonld amount to $(16,683+44,160) \operatorname{logs}=60,8+3$ lngs. The calculation of the output from the streams, howerer, is hased on the assumption that the channels of the Tano and Pra Rivers are 
opened out to timber exploitation by the removal of the obstructions in them. Unless this is done, the annual output in logs cannot be expected to reach much more than 25,000 .

Every efiort, however, should he made to clear the abovementioned obstructions and at the same time to introduce mechanical appliances, such as traction engines, light tramways, \&c. for the haulage and transport of the timber. When this has been accomplished, the Gold Coast, with Ashanti, should he able, and that without any fear of encroaching on the woodproducing capital, to give an annual vield of something like $250,000 \operatorname{logs}$ a year.

Such an out-turn, even at a very mild rate of taxation, should be capable of bringing in an annual revenue of about $£ 60,000$.

These estimates do not include other first-class timbers such as are yielded by the Odoum (Chlorophora excelsa) the Baku (Mimusops D jave), \&e., and are based on the most unfarourahle assumptions. To my mind, the Colony, with Ashanti, has a great future before it, so far as the timber industry is concerned.

The imports of timber for the rears 1898 to 1906 were:-

\begin{tabular}{|c|c|c|c|c|c|}
\hline 1898 & & & & . & $\begin{array}{r}\text { uperficial } \mathrm{F} \\
1,470,125\end{array}$ \\
\hline 1899 & $\begin{array}{l}\cdots \\
\ldots\end{array}$ & $\begin{array}{l}\cdots \\
\ldots\end{array}$ & $\begin{array}{l}\ldots \\
\ldots\end{array}$ & $\begin{array}{l}\cdots \\
\ldots\end{array}$ & $1,225,795$ \\
\hline 1900 & $\ldots$ & $\ldots$ & $\ldots$ & $\ldots$ & $1,872,520$ \\
\hline 1901 & $\ldots$ & $\ldots$ & $\ldots$ & $\ldots$ & $2,823,440$ \\
\hline 1902 & $\ldots$ & $\ldots$ & $\ldots$ & $\ldots$ & $3,3 \pi 8,339$ \\
\hline 1903 & $\ldots$ & $\ldots$ & $\ldots$ & $\ldots$ & $3,125,168$ \\
\hline 1.904 & $\ldots$ & $\ldots$ & $\ldots$ & $\ldots$ & $3,554,850$ \\
\hline 1905 & $\ldots$ & $\ldots$ & $\ldots$ & $\ldots$ & $2,053,816$ \\
\hline 1906 & $\ldots$ & $\ldots$ & $\ldots$ & $\ldots$ & $1,841,698$ \\
\hline & Total & $\ldots$ & $\ldots$ & $\ldots$ & $21,345,751$ \\
\hline
\end{tabular}

which gives a mean annual import of 2,3i1,750 superficial feet, or' nearly one-third of the mean annual export. There is no doubt that the larger portion of the timber imported should be replaced hy local woods, of which there are several kinds arailable that are in every respect suitable for the purposes for which the former are used. Before this can be done, lowever, it will be necessary to establish modern saw-mills along the main lines of export in the Colons, to convert the timber strictly in accordance with the specifications, and to use nothing but properly seasoned wood. It is the custom of placing unseasoned West African woorls on the market that has in so many instances given the former a had name. In fact. it is a matter for consideration whether it would not he advisable for Government to prohibit the felling of trees that have not been previously ring-barked or girdled and killed by the process; this would ensure a proper seasoning of the wood before it is felled.

The establishment of saw-mills with a riew to supplying local demands for converted timber will enable a great deal of timber to be utilised that is at present allowed to lie waste in the forests. 
The fluctuations in the quantity of timber exported from the West Coast of Africa are mainly due to the fluctuations in the prices offered at the home markets. The unstable prices are the most disturbing elements in the local industry, and sererely handicap small capitalists who have embarked in the trade.

$$
\text { List of Vernacular Names of Plants. }
$$

The following list of the native names of plants found on the Gold Coast and in Ashanti, together with their botanical equivalents so far as known, may prove of some use to officials interested in forestry matters:-

$$
\text { Native Name. }
$$

Abousandua (Twi name) ... Ficnss species.

Adadawa (Tassaw name) ... Targe species of Piptadenia (pl. 17 ).

Afana (Twi) ... $\quad \ldots \quad \ldots$ A small unidentified tree.

Affram (Twi) ... $\quad$... $\quad \ldots \quad$ A species of Parinarium.

Ahedua (Twi)... ... ... Cyanothyrsus ogea, the gum copal tree (pl. 15).

Ahedua (Fanti)

Akata (Twi from Denkira) ... Bombax, buonopozcnse, the rerlflowered silk cotton tree.

Akwabohori (Fanti)...

Nkwantanuro (Fanti)

Akwantanuro (Fanti)

Anchi (Fanti)

Appapayi (Twi)

Appayayi (Fanti)

Apurro (Twi)...

Asoma (Fanti)

Asoma, Assomal (Twi)

Assoro (Twi) ...

Atawah, Althawah (Twi)

Anabima (Twi. Denkira)...

Awama

Baku (Fanti. Twi) ...

Baya (Twi)

Biunwè (Tri)

Bosse (Twi)

Bowimasi (Fanti)
Khaya anthotheca, the white mahogany (pl. 4).

Lovoa Klaincana, a good timber tree (pl. 9).

Khaya anthotheca, the white mahogany (pl. 4.)

Pynaertia calacnsis, nood timber tree.

Khaya grandis, mahogany from the shores of the sacred lake (pl. 5).

... A small undescribed tree from the mixed forests.

... Ticinotendron africanus.

... Species of Omphalocarpum :

... The oil-bean tree, Pentaclethra macrophylla.

Heriticra utilis. A good timber tree (pl. 3).

Ricinodendrom africamus.

... Mimusops Djave, a rery good timber tree (pl. 20).

Vitragyne macrophylla.

.. Species of Dctarium, a gigantic forest tree: good timber.

... Speries of Guarea; good timber tree. abore.
... Species of Detarium mentioned 
Native Name.

Bowiwunua (Twi)

Dahomah ('l'wi)

Dahumah ('Twi)

Denya ('Twi) ...

Deinya (Ashanti, Twi) Duakobin, Duabayi ...

Dubin ...

Dubini

Duamenyi (Fanti)

Effuo kon konti (Ashanti) Efuobrodidwa (Twi)...

Emil ... ... ...

Emril ... ... ...

Emiri ... ... ...

Ehyedua (Twi)

Eku (Twi)

Ekusawa (Fanti)

Ekuana (Fanti)

Esseah...

Essia ...

Eye (Fanti) ...

Honum ('Twi)...

Kaku (Twi) ...

Kishia...

Kokotswi (Twi)

Kube (Akrapim) ...

Makube (Ashanti) ...

Kuntunkun (Twi) ...

Kunkuntuni (Denkira)

Kusia (Twi) ... ...

Krubna (Twi)..

Kwabaho (Ashanti) ...

Trwabahori (Twi)

Kwantanuro (Ashanti)

Makube (Ashanti) ...

Meinchin (Apollonian)
Botanical Name.

Species of Deturium, a grigantic forest tree; good timber.

Piptadenia africana, a common forest tree (pl. 16).

The same.

... Large species of Piptadenia (pl. 17).

... A frormosiu laxiftora; good" timber tree; red and white bark.

... The ordinary Khaya (mahogany)

... of the moist evergreen forests.

... Sterculia cordifolia.

I'seudocedrela utilis, the largest

... species of "cedar," a fine timber tree.

... Species of Terminalia; wood good ... for shmgles.

... Gum copal tree (Cyunothyrsus ogea) (pl. 15).

Bombax buonopozense; redflowered silk cotton tree.

Sarcocephalus esculentus (pl. 18).

... The oil bean tree (Pentuclethra macrophylla)

... I Species of Combretum, the "stink-

... W wood "tree.

... Species of Ancistrophyllum, a large kind of rattan.

Anthocleista magnifica, a small tree with very large leaves.

.. Lophira procera, vields a very durable timber.

Sarcocephalus esculentus (pl. 18).

... Pynaertia ealaensis.

... The fan-palm, Borassus fabelli-

... formis.

... I Bombax brevicuspe, a new species

.. i of silk cotton tree (pl. 1).

... Sarcocephalus esculentus (pl. 18).

... Khaya? species.

... Thaya anthotheca, the white mahogany (pl. 4).

... Lovoa" Klaineana, a good "timber tree (pl. 9).

The fan palm, Borassus fabelliformis.

Species of Peltophorum? 
Native Name.
Botanical Name.

Mousandua (Fanti) ... ... Species of Ficus.

N'ku (Ashanti and Tanti) ... Butyrospermum Parlii, the shea

Nya-me dua ... butter tree (pl. 19).

... Alstomia congensis.

N'yankon $\quad \ldots \quad \ldots \quad \ldots \quad$ Heritiera utilis.

Odahuma (Fanti) ... ... Piptadenia ufricana, a common timber tree (pl. 16).

Odenya (Fanti) $\quad \ldots \quad$... Large species of P'iptadenia from evergreen forests (pl. 1i).

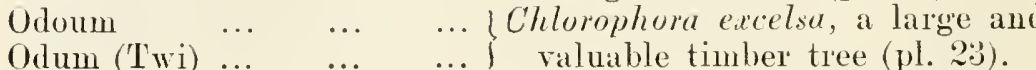

Odupon (Fanti) $\quad \ldots .6$.

Odupin (lenti) $\quad . . \quad \ldots\}$ of the moist evergreen forests.

Offram ('Twi and Fanti) ... Terminalia superba, wood userl for shingles.

Ofu

$\begin{array}{ll}\text { Ohonton (Fanti) } & \cdots \\ \text { Okisibiri (Fanti) } & \ldots\end{array}$

Okitsiwanfu (Fanti)...

Okunmankra (Fanti)

Ongina (T'wi)... ...

Onyina (Fanti) ...

Opapao

Opapea ('Twi)

Opepeh (Fanti)

Osuabise (Akwapim)

Osupawa (Fanti) ...

ute

Owama

Owawa (Fanti)

Pebedum

Penkwa

Prekese

Protodon (Ashanti Akwapim).

Punkwa

Samanta

Samantawa (Fanti) ...

Sese (Fanti) ...

Takwadua (Fanti) ... Takwadua (Twi)
... $\}$ Antiaris toxicaria var. africana.

... The "Flint-wood" tree, not identified.

... Species of Ficus.

... Species of Khaya?

... The "silk cotton tree" (white

... flowered kind), Eriodendron anfruetuosum.

... Afzelia ufricana, a valuable timber tree (pl. 14).

... $\}$ A species of Mimusops?

... Carapa yniunensis.

... Species of Sarcocephalus ?

... Species of Myristica? or Santiriopsis.

... Ricinodendron africunus.

... Triplochiton Johnsonii (pl. 2).

... Lovoa Klaineana (pl. 9).

... Pseudocedrela cylindrica, the cedar, a good timber tree (pl. 10).

... Tetrapleura Thonningii.

and Erythrophloeum guineense, a timber tree from the savannah forests.

... Pseudocedrela eylindrica (pl. 10).

... Xylia Evansii.

... The bastard rubber-tree, Funtumia africana.

... B Blighia sapida. 
Vative Name.

'liama-Tiama...

\section{Botanical Name.}

... New species of l'seudocedrela close to l'. cylindrica, a raluable timber tree of the "cedar" group (pl. 12).

Tombo (general W. coast The wine or bamboo palm, name).

Raphia vinifera.

Wansanwah ('Twi) ... ... Khaya grandis, the species of mahogany found near the Sacred Lake (pl. 5).

Wawa... $\quad \ldots \quad \ldots \quad \ldots$ Triplochiton Johnsonii, a good

Waw-waw $\quad \ldots \quad \ldots \quad \ldots .6$ timber tree (pl. 2).

Wawapupuo $\ldots$... $\quad \ldots \quad$... Sterculia cordifolia

$\left.\begin{array}{llll}\text { Yankom } & \ldots & \ldots & \ldots \\ \text { Yankun } & \ldots & \ldots & \ldots\end{array}\right\}$ Heritieru utilis (pl. 3).

$\left.\begin{array}{llll}\text { Ya-ya ... } & \ldots & \ldots & \ldots \\ \text { Yar-yar } & \ldots & \ldots & \ldots\end{array}\right\}$ Hitragyne macrophylla.

The identification of some of the plants is rather uncertain; such have a note of interrogation placed after their names.

H. N. Thompson,

Conservator of Forests,

Southern Nigeria.

\section{EXPLANATION OF 'THE PLA'TES.}

\section{Plate 1. \\ Bombax brevicuspe.}

Figs. 1 and ״, branchlets; 3 , fruit ; 4 , central axis of fruit, and calyx; 5 , seed ; 6 , hair from immer wall of fruit.-Figs. $1-5, \times \frac{2}{3} ; 6, \times 2$.

Plate 2.

Triplochiton Johnsonii.

Fig. 1, flowering branch ; "2, flower with part of calyx and pelals cut off : 3 , petal ; 4, apex of gonophore, witl two staminodes and all but one pair of stamens removed; 5 , pair of stamens; 6 , longitudinal section of carpel.Fig. $1, \times \frac{2}{3} ; 2, \times 3 ; 3, \times 2 ; 4, \times 4 ; 5, \times 5 ; 6, \times 8$.

\section{PLATE 3.}

\section{Heritierce utilis.}

Fig. 1, flowering branch ; 2, upper part of leafy braneh ; 3, tetramerous flower ; 4 , pertamerous flower laid open ; 5 , pistil ; 6 , carpel : 7 , peltate scale from carpel : 8 , fruit ; 9 , seed ; 10 , section through sced.-Figs. 1-2, $\times \frac{2}{3}$; $3-4, \times 3 ; 5-6, \times 8 ; 7, \times 50 ; 8-10, \times \frac{2}{3}$.

\section{Plate 4.}

Khaya anthotheca.

Fig. 1, leaf ; 2, lcaflet; 3, empty capsule ; 4, seed ; 5, cross section through sced.-Fig. $1, \times \frac{1}{2}: 2, \times \div 3, \times \frac{2}{5}: 4-5, \times \frac{2}{3}$. 
Plate 5.

Khaya grandis.

Fig. 1, leaf; 2 , leaflet; 3 , open capsule with some of the seeds removed; 4 , seed ; 5 , cross section through seed.-Fig. $1, \times \frac{1}{6} ; 2, \times \frac{2}{3} ; 3, \times \frac{1}{2} ; 45, \times \frac{2}{3}$.

\section{Plate 6. \\ Khayee Punchii.}

Fig. 1, flowering branch; 2, flower with eorolla removed; 3, portion of stamilal tube from within; 4 , pistil; 5 , longitudinal seetion of pistil.Fig. $1, \times \frac{1}{2} ; 2, \times 4 ; 3-5, \times 5$.

\section{PLATE 7.}

Khuygu senegulensis.

Fig. 1, flowering branch : 2, fruiting braneh : 3-6, male flower :-3, expanded ; 4 , with the corolla removed; 5 , part of staminal tube from within ; 6 , abortive pistil ; 7-8, female flower: -7 , part of staminal tube from within; 8 , calyx and pistil : 9, cipsulc ; 10, seed : 11, cross seetion through seed.-Fig. $1, \times \frac{2}{3} ; 2, \times \frac{1}{7}$; 3 , natural size $; 4-6, \times 2 ; 7-8, \times 3 ; 9-11, \times \frac{2}{3}$.

\section{PLATE 8 .}

\section{Kherye sp. "Dubini" of the Fantis.}

(Thompson, o. 17).

Fig. 1, fruiting branch ; 2, leaflet; 3, empty capsule.-Fig. $1, \times \frac{1}{3} ; 2-3, \times \frac{2}{3}$.

\section{Plate 9.}

\section{Lovou Klaineanu.}

Fig. 1, fruiting branch: 2, portion of a lower leaf; 3, portion of young inflorescence : 4 , flower ; 5 , flower with petals removed; 6 , portion of upper' part of staminal tube from within ; 7, pistil ; 8 , fruit ; 9, central axis of fruit ; 10, seed ; 11, embryo.-Fig. $1, \times \frac{1}{2} ; 2-3, \times \frac{2}{3} ; 4, \times 4 ; 5, \times 5 ; 6, \times 9 ; 7, \times 6$; $8-11, \times \frac{2}{3}$.

\section{PLA'TE 10. \\ Pseudocedrele cylindrice.}

Fig. 1, fruiting branch : 2, leaf : 3 , a small fruit; 4 , central axis of a large fruit; 5 , seed from small fruit.-Figs. $1-2, \times \frac{1}{2} ; 3-5, \times \frac{2}{3}$.

\section{Plate 11. \\ Pseudocedrele Kotschyi.}

Fig. 1, flowering branch ; 2 , flower ; 3 , flower with petals removed : 4, portion of upper part of staminal tube from within; 5 , pistil ; 6 , fruit; 7 , sced ; 8, embryo.-Fig. $1, \times \frac{2}{3}: 2, \times 4 ; 3, \times 3 ; 4, \times 8 ; 5, \times 5 ; 6, \times \frac{1}{2} ; 7-8, \times \frac{2}{3}$.

\section{Plate 12.}

Pscudocedrela sp. (near $P$. cylindricu).

(Thompson, No. 36.)

Fig. 1, leaf ; 2 , fruit.-Fig. $1, \times \frac{1}{2} ; 2, \times \frac{2}{3}$.

\section{PLATE 13.}

\section{Pseudocedicle utilis?}

(Thompsoll, No. 48.)

Fig. 1, fruit; :2, ralve of fruit; 3 , secd ; 4, embryo.-Figs. 1-4, $\times \stackrel{2}{*}$.

\section{PLATE 14.}

\section{-1jะelia afiricunu.}

Fig. 1, flowering branch; 2, flower ; 3, interior of calyx-tube, upper parts of scpals, petal, stamens and ovary cut off ; $\frac{1}{2}$, valve of fruit from within, showing seeds. - Fig. $1 . \times \frac{2}{3} ; 2, \times 2 ; 3, \times 4: 4, \times \frac{2}{3}$. 


\section{Plate 15.}

Cyanothyrsus ogeu.

Fig. 1, fruiting branch ; 2, leaf ; 3, bud ; 4, flower ; 5, flower with sepals and one petal removed; 6 , a lateral petal ; 7 , an anticous petal ; 8 , longitudinal section of pistil and calyx-tube.-Figs. $1-2, \times \frac{2}{3} ; 3-6, \times 1 \frac{1}{2} ; 7, \times 2 ; 8, \times 1 \frac{1}{2}$.

\section{Plate 16.}

\section{Piptadenice africuna.}

Fig. 1, flowering branch ; 2, flower ; 3, section of flower ; 4, portion of corolla showing insertion of stamens; 5 , anthers; 6 , fruit; 7 , seed.-Fig. $1, \times \frac{2}{3}$; $2, \times 8 ; 3-4, \times 10 ; 5, \times 16 ; 6-7, \times \frac{2}{3}$.

\section{Plate 17.}

\section{Piptadeniu sp.}

(Thompson, No. 27.)

Fig. 1, flowering branch; 2 , bud ; 3 , flower ; 4, pctal ; 5 , pistil and dise with a single stamen $; 6$, authers $; 7$, fruit ; 8 , seed.-Fig. $1, \times \frac{2}{3} ; 2-5, \times 10 ; 6, \times 20$; $7-8, \times \frac{2}{3}$.

\section{PLATE 18.}

Surcocephulus esculentus.

Fig. 1, flowering branch : 2, flower; 3 , flower laid open ; 4, anthers ; 5 , longitudinal section of ovary; 6 , fruit ; 7 , seed.-Fig. $1, \times \frac{\pi}{3} ; 2-3, \times 2 ; 4, \times 4$; $5, \times 6 ; 6, \times \frac{2}{3} ; 7, \times 10$.

\section{Plate 19.}

\section{Butyrospermum Purkii.}

Fig. 1, fruiting branch; 2, inflorescence ; 3, flower ; 4, flower with corollit and stamens removed; 5 , corolla and stamens; 6 , seed.-Figs. 1-2, $\times \frac{2}{3}$; $3-5, \times 2 ; 6, \times \frac{1}{2}$.

$$
\text { Plate } 20 .
$$

\section{Mimusops Djare.}

Fig. 1, flowering branch; 2, calyx and pistil ; 3, corolla and stamens fron without; 4 , corolla and stamens from within ; 5 , anther ; 6 , transverse section of ovary ; 7, fruit; 8 , seed-Fig. $1, \times \frac{2}{3} ; 2, \times 1 \frac{1}{2} ; 3-5, \times 4 ; 6, \times 5$; $7-8, \times \frac{2}{3}$.

\section{Plate 21.}

\section{Funtumia elcestica.}

Fig. 1, flowering branch; 2 , pits on lower surface of leaf ; 3 , flower ; 4, section of flower; 5 , portion of ealyx with the pistil surrounded by the disc; 6 , an anther, front view ; 7 , a pair of open follicles, seen from the back ; 8 , seed.Fig. $1, \times \frac{2}{3} ; 2, \times 2 ; 3, \times 1 \frac{1}{2} ; 4-5, \times 2 ; 6, \times 5 ; 7-8, \times \frac{2}{3}$.

\section{Plate 22.}

\section{Landolphia owariensis.}

Fig. 1, flowering branch; 2, upper part of young fruiting branch ; 3, bud; 4, flower ; 5 , corolla, opened ; 6 , pistil ; 7, anthers ; 8, fruit.-Figs. $1-2, \times \frac{2}{\overline{3}}$, $3-6, \times 3 ; 7, \times 6 ; 8, \times \frac{2}{3}$.

\section{Plate 23.}

\section{Chlorophora excelsu.}

Fig. 1, flowering branch of male ; 2, flowering branch of female ; 3, male flower; 4, female flower ; 5 , pistil ; 6 , longitudinal section of pistil.--ligs $1-2, \times \frac{2}{3} ; 3, \times 7 ; 4-6, \times 8$.

\section{Plate 24.}

\section{Mlusunge Smithii.}

Fig. 1, male inflorescence and young leaf ; 2 , branchlet bearing female in florescences; 3 , head of male flowers ; 4 , male flower and bracteoles ; 5 , female flowers ; 6 , seed; 7, longitudinal section of seed.-Figs. $1-2, \times \frac{2}{3} ; 3, \times 4$ $4, \times 8: 5, \times 12: 6-7, \times 8$. 


\section{APPENDIX.}

\section{C'hAPTER CXXVIII.}

FORESTRY.

(No. 14-1902, and P. No. 28-1901, with subsequent amendments.)

\section{Short Title.}

1. This Ordinance may be cited as "The Forestry Ordinance."

\section{Definitions.}

2. In this Ordinance and in any Rules and Orders made thercunder unless the context otherwise requires :-

(1) "Tree" includes palms, bamboos, stumps, brush-wood and canes ;

(2) "Timber" includes trees when they have fallen or have been felled, and all wood whether cut up or fashioned, or hollowed out for any purpose ;

(3) "Forest Produce" includes :-

A. The following, whether found in or brought from a forest or not, that is to say, timber, charcoal, rubber, gutta percba, wood oil, resin, natural varnish, and bark lac.

B. The following, when found in or brought from a forest, that is to say :-

(i). Trees and leaves, Howers and fruits, and all other parts or' produce not hereinbefore mentioned of trees, and

(ii) Plants not being trees (including grass, creeper's, reeds and moss, and ail parts or produce of such plants);

(iii) Peat, surface soil, and other substances other than minerals to which the Mining Regnlation Ordinance or other law amending the same applies.

(4) "Lands at the disposal of the Government" mean any lands of which the Crown has acquired or may acquire the ownership by conquest, capitulation, treaty, grant or in any way other tban by agreement under the provisions of this Ordinance;

(5) "Native lands" means any waste, forest and other lands at the disposal of a Native community and not being the private property of any individual ;

(6) "To take timber" includes to fell trees and to carry away the timber from the lands upon which the trees have fallen or been felled;

(7) "Enquiry" means any enquiry by a Reserve Settlement Commissioner under this Ordinance;

(8) "Forestry Officer" means any officer appointed by the Governor under section 3 of this Ordinance;

(9) "Native Community" means any group of persons occupying any lands in accordance and subject to Native law, and subject to the control and authority of any Chief or Chiefs ;

(10) "Reserve Settlement Commissioner" "includes any person appointed by the Governor to act on behalf of or in succession to the Reserve Settlement Commissioner appointed by a notice under section 6 .

\section{Appointment of Forestry Ofjicers, dic.}

3. The Governor may from time to time appoint such officers as he may think necessary for carrying the provisions of this Ordinance and any orders and rules thereunder into effect, at such salaries and upon such conditions as be may think fit; and way revoke any such appointment. 


\section{Poucer to Constitute Reserves.}

4. It shall be lawful for the Governor to constitute any of the following lands rescrves, namely:-

(i) Lands at the disposal of Grovernment;

(ii) Lands acquired by agreement under section 5 (i) hercof ; and

(iii) Lands in and over which the Governor bas acquired by agreement the rights referred to in section 5 (ii) hereof.

\section{Acruisition of Lands und Rights by Agreement.}

5. It shall be lawful for the Governor to acquire by agreement from any Natives or Native communities owning the same:

(i) Any lands upon which trees and forest produce or any kinds thereof are growing or which are suitable for the production of trees and forest produce, together with such rights and powers as are necessary or expedient for the use and enjoyment of such lands and subject to such rights and reservations as are set forth or referred to in the agreement, for the use or benefit of the owners of the lands or any other persons ; and

(ii) The right to take timber and collect forest produce or any kinds thereof specified in the agreement, together with such additional rights and powers as may be necessary and advantageous for the exercise, enjoyment and continuance of the said rights by the Governor or his licensees, and subject to such rights and reservations as are set forth or referred to in the agreement for the use or benefit of the owners of the lands or any other persons.

\section{Notification of Intention to C'reate Reserve and Appointment of Reserve Settlement Commissioner.}

6.-(a) When it is proposed to constitute any lands a forest reserve a notice shall bc published in the Gazette,

(i) Specifying as nearly as may be the situation and limits of the lands;

(ii) Declaring whether the lands are lands at the disposal of the Government, or lands aequired by the Governor, or land in respect of which the Governor has acquired rights under the provisions of this Ordinance ;

(iii) Declaring that it is intended to constitute such lands a forest reserve, either for the general purposes of Govermment or for the particular use and benefit of the Native community within the limits of whose occupation the reserve is situated;

(iv) Appointing an officer, hereinafter referred to as the Reserve Settlement Commissioner, to enquire into and determine the existence, nature and extent of any rights claimed by or alleged to exist in favour of any persons or communities or brought to the knowledge of the said Commissioner affecting the lands or the rights in or over the lands which it is proposed to constitute a reserve.

(b) If owing to absence, illness or any other cause the Rescrve Settlement Commissioner appointed under this section is unable to perform his duties, the Governor by notice published in the Gazette may appoint any person to act on his behalf or in succession to him.

(c) Any notice published under this section may be varied, ameuded or revoked

$$
\text { Notice of Enquiry. }
$$

7. Upon publication of the notice aforesaid the Reserve Settlement Commissioner shall immediately cause the particulars contained thercin to be made known in the districts or district in which the lands are situated by causing the same to be read, and interpreted in the local Native language at the next meeting of every Native Court in the said districts or district, and also by orally informing the Chiefs of every community dwelling on or near the lands aforesaid, and shall also fix and in the manner aforesaid make a period within which and a place to or at which any person or community claiming any right affecting the lands or the rights over the lands which it is proposed to constitute a reserve shall either send in written statement of his or their claim to the Reserve Settlement Commissioner or appear before him and state orally the nature aud extent of their alleged rights. 


\section{Einquiry.}

8.-(i) At the expiration of the period fixed by the Reserve Settlement Commissioner, he shall enquire into and determine the limits of the lands specified in the notice aforesaid and the existence, nature and extent of the rights in respect of which he luas received any claims under section 7 and of any other rights alleged to exist or brought to his knowledge at the enquiry in favour of any persons or communities affecting the lands which it is proposed to constitute a reserve the rights acquired by the Governor over any lands under the previsions of this Ordinance.

(ii) The Reserve Settlement Commissioner shall keep a record in writing of all claims made in respect of any rights aforesaid and of any objection which may be made thereto, and also of any evidence given in support of or in opposition to any claim.

\section{Powers of Reserve Settlement Commissioner at Enquiry.}

9. For the purposes of the enquiry, the Reserve Settlement Commissioner shall hare all the powers conferred upon a District Commissioner by the Supreme Court Ordinance.

\section{Juelyment on Completion of Einquiry.}

10. Upon completion of the enquiry, the Reserve Settlement Commissioner shall deliver his judgment, describing the limits of the lands specified in the notice aforesaid and setting forth, with all such particulars as may be necessary to define their nature, incidents and extent, the rights in respect of which he has received claims under section 7 and of any other rights alleged to exist or brought to his knowledge at the enquiry in favour of any persons or communities, and admitting or rejecting the same wholly or in part.

11.-(1) Any person who has made a claim may within three calendar months of any judgment made under section 10 appeal from such judgment to the Supreme Court.

(2) The procedure and practice for the time being in force relating to appeals from District Courts to the Supreme Court shall apply to appeals from the Reserve Settlement Commissioner.

\section{Order Constituting Reserves.}

12.-(1) At the expiration of three calendar months from the date of the judgment made under section 10 , or, if any appeal has been made to the Supreme Court against such judgment, upon the decision of the Supreme Court, the Governor may make an order constituting the lands in respect of wbich the enquiry has been held a forest reserve. Such order shall set forth the limits and situation of the lands which constitute the reserve, and all rights affecting the same as set forth in the judgment of the Reserve Settlement Commissioner, or established by the decision of the Supreme Court.

(2) Such order shall be published in the Gazette and in the manner prescribed for making known the notice referred to in section 7 .

(3) Any order made under this section may be revised or modified.

\section{Extinguishment of light.}

13. Every right in or over any lands in respect of which no claim bas been made under section 7, or of which no knowledge has been acquired at the ellquiry shall be extinguished, unless the claimant has satisfied the Reserve Settlement Commissioner before the delivery of his judgment that he had good reasoll for not preferring his claim within the period fixed under section $\tau$, in which event the Commissioner may defer his juagment until he has decided such claim.

\section{Aequisition of Rights admitied by Reserve Settlement Commissinner.}

14. Where in the opinion of the Governor it is expedient that any right admitted by the lieserve Settlement Commissioner shall be acquired by the 
Government, the Governor may acquire the same by agreement with the owner thereof, or compulsorily under the provisions of the Public Lands Ordinance, which shall be deemed to be applicable for the acquisition of such rights.

\section{Power's of Natives to Grant Absolutely.}

15. Notwithstanding any Native law or custom to the contrary, any Natire, and the Chiefs of any Native community on behalf of such community shall be entitled to enter into any agreement to grant and convey absolutely any lands, and any rights in and over any lands owned by them which it is proposet to constitute a forest reserve under the provisions of this Ordinance.

\section{Power to Declare Lands no longer a Reserve.}

16. The Governor may by order direct that from a date named therein any lands or any part thereof constituted a forest reserve under this Ordinance shall cease to be a forest reserve or a part of such reserve, and thereupon from such date such lands or part thereof shalt cease to be a forest reserve or a part of such reserve; provided that the rights, if any, which have been extinguished therein shall not revive in consequence of such cessation.

\section{Colmial Secretary may Execute Grant.}

17. When the owner or owners have consented tc grant any concession, lease or licence under the terms of this Ordinance, or the rules made thereunder, the Colonial Secretary may execute any instrument making such grant on behalf of the owner or owners, and such execution shall bind the owner or owners and his or their successors in title as effective!y as if it had been duly executed by him or them, provided that at the time of such execution there shall be attached to the instrument a certificate in writing signed by the Colonial Secretary that the consent of the owner or owners has been obtained to the grant.

\section{Prohibitions.}

18. The Governor in Council may from time to time by any order prohibit the following things, or any of them, namely :-

(1) The taking and collection of timber, rubber, and forest produce or any kinds thereof specified in the order in any forest reserves and Native lands, either generally or for the purpose stated in the order, by any persons other than the holders of concessions, leases or licences granted in accordance with rules made under this Ordinance, or by any other persons or by any classes of persons specified in the order ;

(2) The taking and collection of timber, rubber and forest produce, or any kinds thereof specified in the order, in any forest reserves and Native lands during any period specified in the order;

(3) The sale, offering for sale, purchase and export of timber, rubber and forest produce, or any kinds thereof specified in the order, by any per'sons other than the holders of concessions, leases or licences granted in accordance with rules made under this Ordinance, or by any other persons or by any classes of persons specified in the order;

(4) The sale, offering for sale, purchase, possession and export of timber, rubber and forest produce, or any kinds thereof specified in the order, taken, collected or prepared in contravention of any order or any rules under this Ordinance;

(5) The sale, offering for sale, purchase, possession and export of timber, rubber and forest produce, or any kinds thereof, taken, collected, prepared, sold or purchased in any territories near or adjacent to the Protectorate in contravention of the law for the time being in force in such territories;

(6) The sale. offering for sale, purchase, possession and export of timber rubber and foresi produce, or any kinds thereof specified in the order, during any period prescribed by the order.

And the Governor in Council may from time to time by any order vary or revoke any order made under this section. 
Every order made under this section may be subject to such limitations, exceptions and conditions as may be thereiu prescribed.

Any person who shall contravene any order under this section shall be liable on conviction to a fine not exceeding one hundred pounds or to imprisonment for a term not exceeding twelve months.

\section{Fees, Royalties, dec.}

19. The Governor may with the consent signified by resolution of the Legislative Council make rules regulating-

(1) The fees to be charged on the grant and issue of concessions, leases and licences : the rent and royalties to be paid by the holders thereof ; export duties on timber, rubber and forest produce; tolls on timber, rubber and forest produce conveyed on any river or creek opened or improved by the Government; and the costs of surveys and demarcations.

(2) The collection, payment and disposal of fees, royalties, duties, tolls, and costs of surveys and demarcations.

\section{Rules.}

20. The Governor in Council may from time to time make, and when made, vary or revoke rules with respect to the following things or any of them, namely :-

(1) Application for grant and issue of (a) concessions, leases and licences, to take and collect timber, rubber aud forest produce on forest reserves and Native lands ; and (b) licences to sell, purchase and export timber, rubber and forest produce ;

(2) Conditions on which coucessions, leases and licences may be granted, and the forms of such concessions, leases and licences;

(3) Quantity of timber, rubber and forest produce which may be taken and collected by holders of concessions, leases and licences, or in any area or areas of the Colony or Protectorate ;

(4) Survey and demarcation of forest reserves and Native lands, and any areas the survey and demarcation of which is required for the purposes of this Ordinance :

(5) Marking of timber ;

(6) Use and possession of marking instruments ;

(7) Taking, collection and preparation of timber, rubber and forest produce ;

(8) Seizure, detention and disposal of timber, rubber or forest produce, taken, collected, prepared, sold, offered for sale, purchased, possessed, or not marked in contravention of any order or rule under this Ordinance;

(9) Returns and accounts to be furnished by holders of concessions and licences ;

(10) Termination, revocation and forfeiture of concessions and licences ;

(11) Transit of timber by land and water ;

(12) Salving and disposal of drift timber ;

(13) Establishment and maintenance of nurseries :

(14) Preservation and reproduction of timber, rubber and forest produce:

(15) Introduction of new species of timber, rubber and forest produce ;

(16) Management, utilization and protection of forest reserves;

(17) Duties and discipline of Forest Officers ;

(18) Generally any matter connected with the carrying of the purposes of this Ordinance into effect.

The Governor in Council may attach a fine not exceeding fifty pounds, or a term of imprisonment not exceeding six months, to auy breach of any rule made under tbis section.

\section{Publication of Orders and Rules.}

21. All orders and rules made under the provisions of this Ordinance shall be published in the Gazette, and shall upon such publication hare full force and effect, subject to disallowance by His Majesty. 
Provided that no order or rule made as aforesaid shall come into force in any district or province to which the Native Councils Ordinance applies, unless the same shall have been approved by the Native Council, duly constituted in accordance with the provisions of the said Ordinance for the district or province affected thereby.

Provided also that all rules and orders shall in erery case apply to all Crown lands and lands leased or held by the Crown.

\section{Jurisdiction of Commissinners.}

22. Proceedings under this Ordinance may be taken before any District Commissioner, who shall have full jurisdiction to determine summarily all such proceedings, or before any Native Council duly constituted under the Native Councils Ordinance.

\section{Forfeiture.}

23. In addition to any fine or term of imprisonment which any Court may impose under this Ordinance or any rule thereunder, such Court may order the forfeiture and give directions as to the disposal of the timber, rubber, forest produce, instrument or means in respect of which or by which the offence has been committed.

\section{Pronf of Krnouledge.}

24. Where a person is charged with the breach of any order, prohibiting the sale, offering for sale, purchase, possession or export of timber, rubber or forest produce, either taken, collected or prepared in contravention of any order or rule under this Ordinance, or taken, collected, prepared, sold or purchased in any territories aforesaid, near or adjacent to the Colony or Protectorate, in contravention of the law for the time being in force in such territories, such person shall be liable to be conricted of such breach, unless he shows to the satisfaction of the Court that he was unaware that such timber, rubber or forest produce was taken, collected or prepared in contravention of any order or rule aforesaid, or was taken, collected, prepared, sold or purchased in contravention of any law aforesaid, as the case may be.

\section{Drders and Rules in Schedule to be in Force.}

25. Unless and until further or other provision be made in the manner above prescribed, the rules and orders contained in the schedule hereto shall be and remain in force, subject to the provisions of section 21 hereof.

\section{THE SCHEDUT.E.}

\section{Rules relativg to Rubrer.}

Title.

1. The rules may be cited as "The Rubber Rules."

\section{Definitions.}

2. In these rules, unless the context otherwise requires,-

(1) "Head Chief" or "Chiefs" means any Chief or Chiefs having paramount authority over a Native community.

(2) "Headinan" or "Headmen" means any Chief or Chiefs having immediate control and authority over a Native community.

(3) "Licence" means a licence to collect rubber.

(4) "Native Lands" means forest lands belonging to Natives and Native communities.

(5) "District" means a district constituted under the provisions of the Supreme Court Ordinance, and any part of such district.

(6) Other expressions shall have the same meanings as are given in the Forestry Ordinance.

( 7 ) "Tapping" means either the process of extracting the rubber-producing latex, or the single act of cutting trees for the purpose of such extraction, according as the context requires. 


\section{Applications for Grant and Tssue of Licences.}

3. Applications for licences to collect rubber in any district shall be made to and licences may be granted and issued by, the District Commissioner or by any European Forest Officer of the District.

\section{General Ponrers of Licensee.}

4. Subject to the provisions of these rules a licensee shall be entitled to collect rubber on any Reserve and on any Native lands in the district named in his licence.

\section{Applicant whose Previons Application has been Refused.}

5. If any person who has been refused a licence or whose licence has been forfeited in any district shall apply for a licence in the same or any other district, he shall, upon making such application, inform the District Commissioner or Forest Officer to whom his application is made of the fact that he has previously applied for and been refused a licence, or that his licence has been forfeited and, if known to him, the reasons for such refusal or forfeiture.

\section{Right, to Refuse to Issue Licence.}

6. No person shall be entitled as of absolute right to the issue of a licence.

\section{Duration of Lience.}

7. Licences shall be granted for the period mentioned therein.

\section{Applicants to have Knovledge of Tapping.}

8. Any applicant for a licence may be required to satisfy the officer to whom the application is made that he has a competent knowledge of the proper method of tapping trees and preparing rubber.

$$
\text { Fees, dee to be Paid before. Issue of Lieence. }
$$

9. No licence shall be issued until the fees and commuted royalties prescribed by these rules have been paid.

\section{Form of Licence.}

10.-(a) Iicences shall be printed in triplicate, and may be in Form A appended hereto. Rules $2,12,13,14,15,16,17,18,24,25$ and 26 shall be endorsed thereon.

(b) Licence forms shall be bound into books. Every book shall contain 50 licences in triplicate, or such other number as the Conservator of Forests may direct. The books and licences in every book shall be numbered consecutively from 1 upwards. The duplicate and triplicate of every licence shall bear the same number as the original.

\section{Triplicate of Licences to be sent to principal Forest Officers for Filing.}

11. The District Commissioner and every Forest Officer of a district shall, upon issuing a licence, send the duplicate therenf to the Forest Officer in cliarge of the Register referred to in rule 23, or if the Forest Officer issuing the licence is also the officer in charge of the Register aforesaid, such officer shall retain the duplicate of such licence. Every duplicate received or retained by the officer in charge of the Register shall be filed by him in his office.

\section{Licences not Transferable}

12. Licences are not transferable 


\section{When a Licensee is not a Native of District Consent of Chiefs to Collection of} Rubber to be obtained.

13. When a licensee is not a member of a Native community of the district to which his licence relates, he shall, before collecting rubler on the lands belonging to any Native community of the district, obtain the consent of the Head Chiefs of the community to the collection by him of rubber on the lands belonging to such community.

\section{Production of Licences.}

14. Every licence shall be produced by the licensee at the request of any Chief or Headman of any community upon whose lands the licensee may be collecting rubber.

\section{Girth of Tiees to be Tapped.}

15. No tree of less girth than thirty-six inches at a height of four feet from the ground shall be tapped.

\section{Method of Tapping.}

16. In tapping trees the following or such other methods as may from time to time be prescribed by notice published in the Gazette shall be followed :-

(1) -

(a) The cuts shall be $\mathrm{V}$ shaped, the two arms of the $\mathrm{V}$ being each 2 in. long and separated at their widest part by 2 in., the apex of the $V$ to point downwards.

(b) The distance between any two adjacent V's must not be less than $2 \mathrm{in}$.

(c) The maximum width of any cut shall not exceed $\frac{1}{2}$ in.

(d) No tapping shall be done higher up the tree than twelve feet from the ground nor extend to a greater vertical distance than four feet.

(e) Tapping shall only be undertaken in the early morning and must cease by 8 a.m.

$(f)$ On the first day of tapping a series of V's of the prescribed size should be spaced round the tree at interval of not less than 3 in. between any two adjacent V's. The cuts made on the first day should be very narrow and should in no case penetrate deeper than the cambium layer and on no account must they enter the wood. No tapping should be done on the following day, but on the next day, the third from the commencement of the tapping, a very thin shaving should be pared off the lower side of each of tha V's cut on the first day, so as to expose a new surface, and the latex collected; on the fourth d ıy no tapping is done and the tree is given a rest; on the fifth day another thin shaving is pared off the lower side of each of the V's, fresh surfaces are thus exposed and the latex collected. This process of one day's tapping followed by a day's rest should be continued till the cuts have reached a maximum width of $\frac{1}{2}$ in., when another series of fresh V's can be startied; provided that the number of tappings (consisting of initial cutting of V's plus number of subscquent parings) docs not exceed ten in one year. That is counting from the first day of tapping not more than ten cuttings, and subsequent parings ean be done during the next twelve months. The cutting and paring should be done with the sharpest of knives.

(g) Trees already tapped shall not be again tapped until the old cuts on them have completely closed over and healed.

(h) The latex must be collected and coagulated in clean vessels, and on no account must dirt or any extrameous matter be allowed to contaminate the latex. The latter should be strained through fine muslin or wire gauze before it is coagulated.

\section{Alternative Method of Tapping.}

(2) The half herring bone method:-

(a) On the first day a channel is cut vertically from the base of the trunk to a beight of $3 \mathrm{ft} .6$ in. From this vertical channel branch channels are 
cut, at an angle of $45^{\circ}$ with the main channel, and on one side only of that channel. The branch cuts should be at intervals of 6 in. The side channels are not to go more than quarter round the tree.

(b) On the second day the tree is given a rest.

(c) On the third day each of the branch channels is reopened by taking a thin shaving off the lower side of the old cut. The vertical channel is not reopened.

(d) On the fourth day the tree is giren a rest.

( $\rho)$ On the fifth day the process described under $(r)$ is repeated, and this process of tapping on every alternate day is repeated till the side channels have been reopened nineteen times.

(f) The main channel should be shallow and not exceed $\frac{1}{3}$ in. in breadth.

(g) The side channels should start by being $\frac{1}{8}$ in. wide, then at each shaving not more than $\frac{1}{16} \mathrm{in}$. should be removed. Thus after six shavings the width of the side channels should not exceed $\frac{1}{2}$ in.

(1) After the successive tappings described above (seven in all including the first cutting) have been completed the tree should be given a rest for six months.

(k) At the end of six months another series of similar tappings may be carried out on the opposite side of the tree; an interval of at least six months' rest must then again be given.

(l) (Third tapping.) - At the end of six months' rest the process may be again repeated on a side on which the two tappings described abore were not undertaken. The next or fourth tapping is performed on the quarter of the trunk not yet touched, and subsequent tappings are to be carried out so as to leave each quarter of the circumference the maximum period of rest possible. Successire tappings on each section of the trunk should be carried out so as not to tap any portion of the bark a second time until the whole of the untouched surface of the bark on that section has been tapped.

\section{Collecting Rubber from Vines.}

17. In collecting rubber from vines the rine may be cut down, but two and a half feet at least of the stem shall be left intact, and no vine less than six inches in girth at two feet from the ground sliall be cut.

\section{Latex to be Strained.}

'The latex collected from vines must be strained through musliu or wir: gauze or otherwise cleaned in order to get rid of extraneous matter before it is coagulated.

\section{Licence Liable to Forfeiture when Rubber Adulierated.}

18. Any licence-holder found guilty of preparing 1 ubler adulterated with dirt or other extraneous matter will be liable to have his licence forfeited.

\section{Nurseries.}

19.--(1) Native communities entitled to royalties under rule 21 shall establish and maintain nurseries for rearing rubber plants, and plant out such plants in such manner and at such times and places as the Forest Officers may from time to time direct: Provided that such Native communities shall not be bound to expend greater amounts for the purposes aforesaid than one half of the sums receired by them as royalties.

(2) If any Native community shall for any period fail to comply with the conditions of this rule the Governor may make an order directing any Forest Officer to perform the same on behalf of sucl community until further order, and all royalties sball cease to he paid to the community until the amount of ruyalty unpaid shall equal the cost of planting, and the royaltits payable to such community during the continuance of the order aforesaid shall be applied in the performance of the said conditions. 
Fees.

20. The following fees shall be paid, namely :-

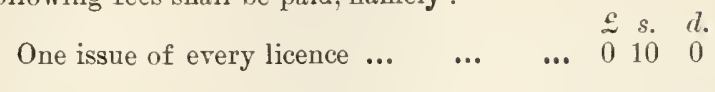

Royalties.

The following commuted royalties shall be payable, namely :-

By every licensee, other than a licensee who is a member of a Native community of $\begin{array}{llllllll}\text { the } \text { district } & \ldots & \ldots & \ldots & \ldots & 0 & 10 & 0\end{array}$

\section{Distribution of Royalties.}

21.-(1) Where the lands upon which rubber is collected under a licence are Native lands, the commuted royalties, if the lands are owned by one community, shall belong to such community, or, if the lands are owned by two or more communities, shall be allotted to such communities in such proportions as, having regard to the number of trees tapped or vines cut, the Forest Officer haring the supervision of such lands stall advise, and the royalties belonging to or allotted to each community shall be divided among and paid by the District Commissioner to the Chiefs, Headmen and other members of such community in such proportions as may be prescribed by Native law, or in the absence of a Native law, in such proportions as the District Commissioner may direct.

(2) Subject to the provisions of these rules all fees and royalties shall be paid into the Treasury and form part of the revenue of the Colony.

\section{Remission, de. of Fees, \&c.}

22. The Gorernor may, if he thinks fit, lessen or remit any fees or royalties prescribed by these rules, and if any fees have been paid into the Treasury may order their refund.

\section{Licence Register.}

23. The Forest Officer deputed in every district by the Conservator of Forests for the purpose shall keep a Register of all licences issued in the district. The Register, which shall be known as a Licence Register, may be in the Form B appended hereto, and may contain the particulars indicate 1 in the said form.

\section{Seizure.}

24. Any Commissioner or Forest Officer may himself, or by any person acting under his directions, seize any rubber collected, prepared, sold, offered for sale, purchased or possessed, or suspected of having been collected, prepared, sold, offered for sale, purchased or possessed in contravention of any order or rule made under the Forestry Ordinance, and may detain the same until the Court has given directions as to the disposal thereof.

\section{Forfeiture of Licence.}

25. Upon breach of rules $5,12,13,14,15,16$ or 17 the licence of the person committing the breach may be forfeited, and shall be delivered on deinand to any Commissioner or Forest Officer of the district in which the breach has been committed.

\section{Penalties.}

26. Any person who shall commit a breach of rules 5, 12, 13, 14, 15, 16 or 17 shall be liable, on conviction, to a fine not exceeding fifty pounds, or to imprisonment for any period not exceeding six months, with or without hard labour. 

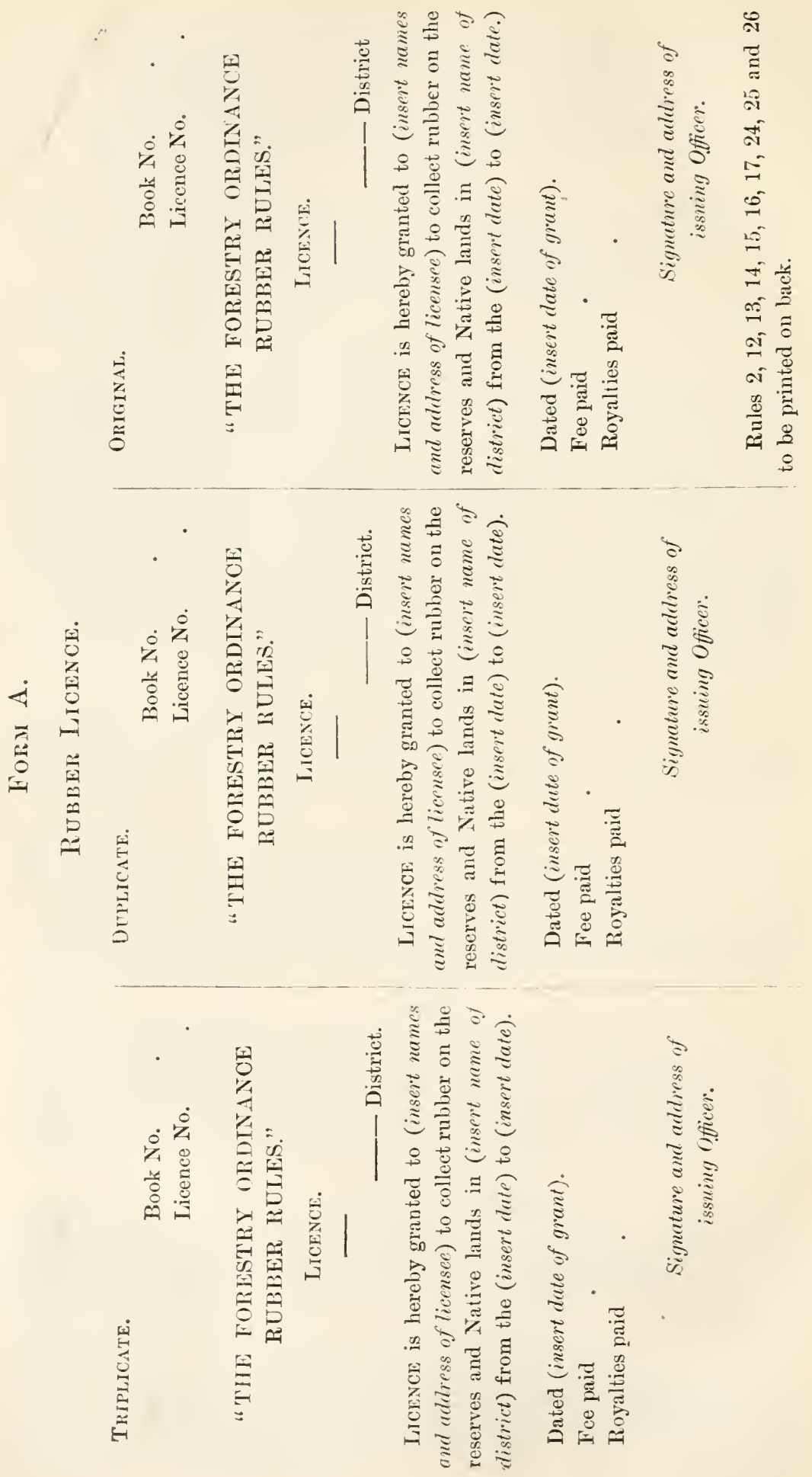
Form B.

Lidence Register.

(Insert nume of district) District.

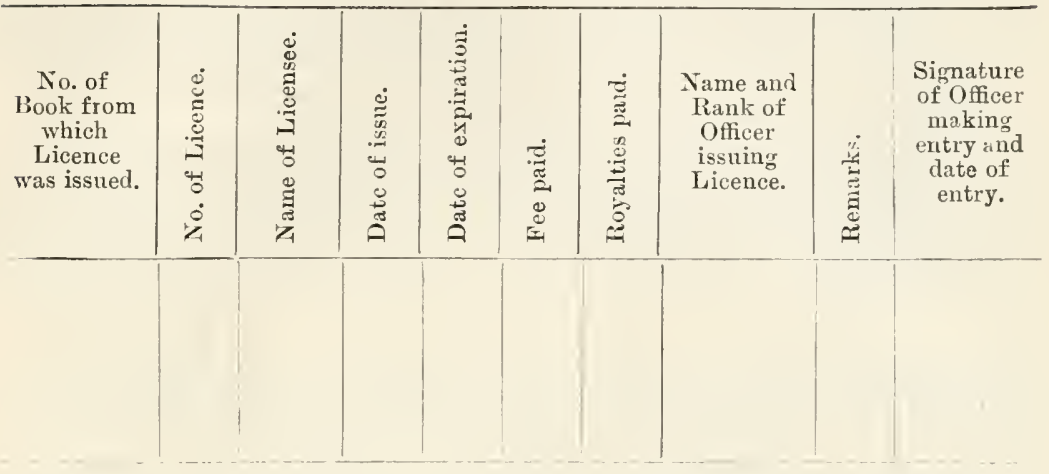

2. Order setting fortil tile ACts prohibited under Section 18.

The following acts are hereby prohibited :-

(1) The taking on Native lands of mahogany trees of the genera Khaya (known as the Oawango of the Benis and Gadeau of the Yorubas) and Entandrophragma (known as the Ikpwapobo and Onomokyukyu of the Benis and Ahtore of the Efiks), of so-called cedars belonging to the genera Trichilia, Pseudocedrel $a$ and Guarea (known as the Opobo, Opobonikwi and Opobonufwa of the Benis), and of ebony and orher timber for export by persons other than the holders of licences to take timber or the owners of such lands: Provided that this prohibition shall not apply to ebony on Native lands in the Calabar or Bende district.

(2) The taking of cedars of the genera Trichilia, Pseudocedrela, and Guarea, mahoganies of the genera Entandrophragma and Khaya, Funtumia elastica (known as Iyeri of the Benis), Landolphia owariensis, the vine rubler plant Clitandra elastica, Chlorophora excelsa (known as Oroko of the Benis), the oil bean tree (Pentaclethra macrophylla), the oil nut (Irvingia Barteri), the African oak (Oldfieldia africana), for use in the Colony or Protectorate except in accordance with the rules relating to timber for the time being in force.

(3) The collection of rubber on Native lands and forest reserves by persons other than the holders of licences to collect rubber.

(4) The collection of root rubber from the roots of Funtumia elastica (known as Iyeri of the Benis) and of any other rubber-yielding tree or plant, excepting such rubber-yielding species as may from time to time be notitied in the Gazette as exempted from the provisions of this Order.

(5) The sale, offering for sale, purchase and export of rubber collected, prepared, sold and purchased in any territories near or adjacent to the Protectorate in contravention of the law for the time being in force in such territories; and

(6) The sale, offering for sale, purchase, possession or export of rubber collected in contravention of the Forestry Ordinance or any rules or orders made thereunder.

(7) And it is hereby ordered that the onus of proof that any rubber has not been collected or acquired in contravention of this order shall lie upon the person in whose possession the same is found, and that in default of such proof the rubber and the person in whose possession the same is found shall be dealt with as if proof had been given that he had acquired such rubber in contravention of this order.

\section{Rules Relating to Timber.}

Applications for and Grant of Licences.

Title.

1. These rules may be cited as "The Timber Rules." 
2. In these rules:-

\section{Definitions.}

"Licence" and "Timber Licence" mean a licence granted under these rules to take timber ;

"Provincial Commissioner" and "District Commissioner" mean respectively the Provincial Commissioner of the province and District Commissioner of the district in which the timber referred to issituated;

"Holder of a Licence" includes the grantee and the assignee of a licence ;

"Conservator" means the Conservator of Forests :

"Owner" includes any Chief or Chiefs having the disposition of any lands, or rights thereover, belonging to a Native community, and any member of a Native community having authority from the Chief or Chiefs of the community ts take timber;

Other expressions shall have the same meanings as are given in the Forestry Ordinance.

\section{No Licence to be Grunted without Approvul of Governor.}

3. No licence shall be granted except with the consent of the Governor.

\section{Particulars to be Furnished by Applicant.}

4. Applicants for the consent of the Governor to a licence shall forward to the Provincial Forest Officer a statement (which shall be regarded as confidential by all concerned) in writing in triplicate, giving, as far as they are able, the full namez, addresses and occupations of the proposed grantees and their financial position, the species of timber to be cut, and the estimated area, positions and boundaries of the lands to be included in the licence.

\section{Procedure on Receipt of A pplication.}

5.- (1) The Provincial Forest Officer, as soon as he has received an application, shall forward such application, with his recommendations respecting the same, to the Provincial Commissioner. If applications have been received from other applicants for licences relating to the same area or any other portion thereof, he shall call attention to the fact, and shall state his reasons for recommending that the licence be granted to the one applicant in preference to the others.

(2) The Provincial Commissioner as soon as possible shall forward the application to the Conservator, and shall state the political reasons, if any, why the licence should not be granted; and the Conservator shall forward it to the Colonial Secretary fır submission to the Governor.

(3) If the Governor decides to approve the grant of licence provisionally, he shall direct the Provincial Commissioner to enquire into and advise as to the title of the proposed grantors and of any other persons claiming to have, or, in the opinion of the Provincial Commissioner, having a right to grant or oppose the grant of a licence, and to grant or refuse the licence accordingly, subject to an appeal to the Governor.

\section{Consent of Secretary of State required in Certain Cases.}

6. No licence over an area exceeding one liundred square miles shall be approved or granted except with the consent of the Secretary of State.

\section{General Rights conferred by Licences.}

7.-(1) Licences shall confer the right to fell and carry away the species of trees named therein, and shall not confer any exclusive right to the use of roads, waterways and river frontages within the area over which the licence is grauted.

\section{Mining Rights.}

(2) The grant of a licence to cut timber shall not preclude an exclusive or general mining licence or a mining lease being granted under the Mining Regulation Ordinance, or any law amending the same, to persons other than the holders of the licence. Provided that when it licence has been granted under 
these rules to take timber over an area in respect of which no such mining licence or lease is in force, the holder's of the licence to take timber shall have the right of applying under the said law for an exclusive or general mining licence over the area over which the said licence to cut timber has been granted, and this right shall give the holders a prior right to be granted such mining licence, which said prior right shall last for six months from the date of the said licence to cut timber.

\section{Duration and Renewal of Licences.}

(3) Subject to the provisions of this rule, licences shall be granted for five years with a right to renew for further periods of two years. Such renewal may be grantel on a certificite from the Conservator that the holders of the licence havs substantially complied with the conditions subject to which the licence is granted.

The refusal of the Conservator to grant a certificate shall be subject to appeal to the Governor.

Applications for renewal shall be made to the Conservator in writing nine months before the date on which the licence would elapse but for such renewal. The order for the renewal shall be endorsed upon the copy of the licence filed in the Land Registry, and a copy of such endorsement shall be sent by the Registrar to the Conservator for transmission to the holders of the licence.

If the applicants or the holders of a licence desire that their licence shall be granted for a longer period than above-mentioned in order that they may construct tramways, monorails or other works for working the timber to be included or included in their licence, they may apply at any time to have such period fixed by the Governor.

\section{Exclusive Water Frontages and other Rights.}

(4) If for any reason it appears to the Governor desirable for the proper working of the timber included in a licence that an exclusive water frontage should be granted, the Governor may issue an order conferring such exclusive frontage. Similarly, if it is conducive to the proper working of any timber that no roads, lines or timber tracks should be made over the lands to be included or included in a licence by the holders of other licences, the Governor may make an order restricting or prolibiting the making of such roads, lines or tracks.

\section{Effect of Provisional Consent to Application.}

8. If the Governor grants his provisional consent to an application for a licence, the fact shall be forthwith notified to the Provincial Forest Officer for the information of the applicant. Unless otherwise stated, the Governor's provisional consent shall mean that the licence sball be drawn in accordance with these rules. The Governor may, however, decide not to give bis consent unless the licence contains special clauses in modification of or supplemental to these rules.

\section{Referenee to Attorney-General for Report on Title of Grantors.}

9. In case there is any doubt as to the title of the grantors, the matter shall be referred to the Attorney-General for report.

\section{If Report be Adrerse.}

10. If such report be adverse the Colonial Secretary shall forthwith notify the Provincial Forest Officer, who shall inform the applicant of the nature of the report, so tbat the applicant may discontinue any expenditure which he m:ty be incurring or which may be incurred on his behalf with a view to obtaining a licence or so that be may endeavour to cure the defect in the title.

\section{Payment of Expenses.}

11. All expenses connected with the delimitation of the lands included in a licence, the marking off of the boundaries, the preparation of the plan of the area of the lands aforesaid and the preparation of and recording of the licence shall be borne by the applicants. 


\section{Delimitation of Lands.}

12. The limits of the lands included in the licence shall, when not in the opinion of the Provincial Forest Officer adequately shown by natural boundaries or by recognised roads, be marked out in the joint presence of the Forest Officer or other person appointed by him for the purpose and of the applicant or lis agent.

Such limits shall be marked out hy placing on trees at the limits of the lands the mark to be shown on the licence.

\section{Delimitution and Marks.}

13. As soon as practicable after the Governor has given his provisional consent to the licence, the Provincial Forest Officer shall settle with the applicant what mark is to be shown in the licence.

\section{Hemmer Marks.}

14. In addition to the marks referred to in the preceding rule the said officer shall also settle with the applicant what hammer marks are to be made on all timber coming from the lands included in the licence.

A register of such hammer marks shall be kept by the Conservator.

Distinctive hammer maris shall he settled in respect of each licence. In settling such hammer marks the Conservator shall 1ake care that no mark shall resemble the marks of any other exporter of timber.

$$
\text { Preparation of Plan. }
$$

15. A plan of the lands included in the licence shall be prepared by the applicant and shall be verified by the Conservator or Forest Officer, or other person appointed by the Governor for that purpose. Such plan shall be attached to the licence.

\section{Preparation of Licence.}

16. The licence sliall ve settled by the Provincial Forest Officer and the grautee. If the Governor has vot decided that the licence shall contain special clauses supplementing or modifying the effect of the rules, the licence may be made out in triplicate (each copy having a plan endorsed thereon) in the office of the Provincial Forest Officer, and after due execution (see next rule) by the grantors and grantees, shall be sent to the Attorney-General by or through the Conservator. If the licences are found to hare been duly executed and stamped and to contain the provisions required by these rules, they shall be forwarded by the Attorney-General to the Provincial Commissiover for signature and registration. One copy shall be filed in the Prosincial Lands Registry Office, and the other two copies shall be sent to the Conservator, who will file one copy in his office and transmit the other to the grantee.

If the licence has to contain special clauses, a draft licence only shall be settled as aforesaid, and this draft shall be sent to the Colonial Secretary for approval of such clauses. After such approval has been obtained the Colonial Secretar y shall return the draft, and further action shall be taken by all concerned, as in the case of an ordinary licence.

\section{Registration.}

When a licence is to be executed by an agent authorized by a power of atturney to execute licences relating to lands on behalf of his principal, such power of attorney should be registered in the same manner as other instruments relating to land at the same time as or before the licence is registered.

\section{Execution of Licence.}

17. Every licence (including all rules incorporated therewith) shall be read over, interpreted if necessary, and explained in the presence of a Commissioner of the clistrict in which the lands included in the licence or the greater part thereof is situated, to the parties thereto, and shall be executed by the parties in the presence of such Commissioner and attested by him, provided that this rule shall not apply to execution by the Colonial Secretary under the prers conferred on him by section 17 of the Forestry Ordinance. 


\section{Species of Timber to be stated in Licences. Sample.}

18. Every licence shall specify the species of trees which the holders of the licence are authorized to fell. Such description shall include the vernacular name of each species in the local dialect. Provided that the holder of a licence may, on giving notice to the Conservator or to any officer appointed by him, cut down and carry away a sample tree of any other species. Such sample tree shall not be liable to royalty or duty. Provided further that the holders of a licence may apply at any time to the Conservator for permission to fell and carly away any other species of tree, and if the Conservator advises that sucb species of tree may be cut, the holder of the licence may apply for a supplemental licence granting the right to fell and carry away such species, but only on condition that no such species of tree shall be taken except in accordance with such instructions regarding the minimum felling girth as the Conservator may in his diseretion prescribe.

\section{Ordinary Conditions subject to which Licences are Granted.}

\section{Commencement and Continuance of Work.}

19. The holders of a licence shall commence work within six months from the date when the Gorernor's assent to the issue of the licence is communicated to them, and during the continuance of such licence shall not discontinue work for any period of more than twenty-four weeks in the whole of any year, or for any consecutive period of more than sixteen weeks, provided that the licence shall not be liable to forfeiture, nor shall the holders thereof be liable to any penalty under these rules or to proceedings on the Bond, if such cessation from work has been, in the opinion of the Provincial Forest Officer, due to cause; bejond the control of the holders of the licence, or if such cessation shall in his opinion bave been desirable on any other grounds.

\section{Procedure to be adopted before Trees are Felled.}

20.-(1) The holders of licences shall mark all trees which they desire to fell, and shall from tire to time prepare a list of such trees describing :-

(a) The girth of the tree at a point 10 feet from the ground;

(b) The vernacular name of the tree intended to be cut;

(c) The situation of the tree; and

(d) The name of the Head Chief of the Native community owning the land on whicb the tree is growing, and the name of the nearest village of such Native community. Such list shall be made out in duplicate and shall be forwarded to the nearest Europexn Forest Officer of the Province. Each copy shall be certified in writing to be correct by the grantees or their agent.

On receipt of the lists the European Forest Officer shall endorse one copy with a statement that fermission is granted to fell the trees described in the list, and after signing his name and adding the date on which the statement is signed, shall return such copy to the holders of the licence or their agent. The other copy shall be filed by the Forest Officer in his office. Upon receipt of the copy of the list endorsed with the statement aforesaid the holders of the licence may fortbwith fell the trees described in such list.

\section{Inspection.}

(2) The European Forest Officer shall as soon as possible inspect, or cause to be inspected, the trees mentioned in the list, or the stumps of the said trees which have been felled in accordance with any permission granted as aforesaid.

\section{P'roduction of Lists.}

(3) The holders of a licence shall retain all lists aforesaid, and shall produce the same when required in order to show their authority for felling the trees.

(4) No timber shall be exported unless it bears the Government pass mark which the European Forest Officer will affix or cause to be affixed at such time and place as may be agreed upon with the licensee.

(5) Every European Forest Officer shall beep proper records of all trees on which he has granted a certificate of rebate under rule 39 . 


\section{Juju, Market and Village Trees.}

21. Notwithstanding the grant of any permiscion under rule 20, the holders of a licence shall not cut down any trees known as "Juju trees" on the lands included in their licence, or any trees within 400 yards of a market or village on the said lands without the previous consent of the Chiefs of such market and the District Commissioner of the district in which such market or village is situated.

\section{Remocal of Trees an Farm.}

22. Notwithstanding the grant of a licence, the grantors of the licence may farm or permit to be farmed any area or areas of the lands included in the licence over which they have the rights of farming. If any area aforesaid which the grantors intend to farm or permit to be farmed contains any species of timber which the holders of the licence have the right to fell under their licence, the grantor, prior to farming or permitting to be farmed such area, shall give not less than three calendar months' notice of their intention to the holders of the licence or their agent in, and the nearest European Forest Officer of, the district in which such area is situated, and if the holders of the licence shall not fell and remove the timber which they have the right to fell and remove from such area before the expiration of the said notice they shall not fel! and remore the same while the areat is being farmed,

\section{Water-wrys not to be Obstructed.}

23. The holders of a licence shall not allow any timber or other matter to fall or be thrown from the lands included in their licence into any waterway which passes through or along the boundares of such lands so as to obstruct the navigation of such waterway. Any logs found adrift or not properly formed into rafts and in charge of raftsmen in any waterway shall be liable to confiscation, provided always that the owner of such logs may re-obtain possession thereof upon payment of a penalty amounting to twenty-eight shillings per $\log$ in the case of mahogany and cedars, and ten shillings per log for other timber. But the payment of such penalty shall not release the owner of such $\log$ or $\log s$ from any civil or criminal liability for damage which he may have incurred.

\section{General Pouers of Grantees.}

24.- (1) The holder's of a licence may on the land included in their licence extend, dig and set up pits, stages and erections, and make such roads and ways as are necessary for dressing and currying away timber, and may erect such houses, offices, sheds and other buildings as are necessiry for the residence and use of their agents, workmen and servants. The holders of a licence shall not damage or allow damage to be done to any rubber or other trees, undergrowth or crops other than such damage as is incidental to and unavoidable in the exercise of the rights conferred by their licence.

\section{Farming.}

(2) No part of the land included in a licence shall be farmed by the holders of the licence unless and until the consent of the owner of such lands and of the nearest European Forest Officer has been obtained.

\section{Girth of Trees.}

25. No mahogany tree of the genera Klaya (known as Ogwango to the Benis and Gadeau to the Yorubas), or Entandrophragma (known as Ik pwapobo and Onomokyukyu to the Bents and Ahtore to the Efiks); and no cedar tree of the genera Pseudocedrela, Trichilia or Guarea (known as Opobo, Opobonikwi and Opobonufwa to the Benis) of a less girth than twelve feet at a point ten feet from the ground; and no tree of the species Chlorophora excelsa (known as Oroko to the Benis and Yorubas) of a less girth than nine feet at a point four feet six inches from the ground; and no tree of the species Oldfieldia africana (African Oak) of a less girth than eight feet at a point four feet 
six inches from the ground; and no ebony of less girth than ton feet at a point four feet six inches from the ground; and no tree of the species Funtumia elastica (known as Iyere to the Benis) of a less girth than six feet at a point four feet six inches from the ground; and no tree of the species Pentaclethra macrophylla of a less girth than five feet at a point four feet six inches from the ground; and no Dika nut tree or wild mango, Irvingia Barteri, of a less girth than six feet at a point four feet six inches from the ground shall be felled: Provided that these dimensions may be reduced by order of the Governor in any district or locality named in such order, where the trees do not attain to such dimensions.

\section{Marking Stumps and Logs.}

26.-(1) The stump of every tree felled and the logs from every such tree shall be marked as soon as possible after the felling thereof with the hammer mark of the holders of the licence and with numbers. The stumps shall be marked consecutively, and the logs from each tree shall bear (1) the stump number of such tree, and (2) log numbers running consecutively from one upwards.

\section{Removal of Stumps.}

(2) The holders of a licence wishing to remove the stump of a tree shall apply for permission to the nearest European Forest Officer and such Officer may with or without an inspection of the stump by himself or some other Forest Officer grant the necessary permission.

\section{Re-planting by Holders of Licences.}

27.-(1) The holders of a licence shall plant or tend young trees in every open space caused by the felling of a tree and along all disused timber tracks. The trees to be planted or tended in such open spaces shall be of the same species as the tree which was cut, and those to be planted in such tracks shall be mahogany or such other species as may be allowed by the Provincial Forest Officer.

The young trees aforesaid may be obtained by the holders of the licence transplanting from the adjacent forest. but if suitable trees cannot be thus obtained the holders of the licence shall establish nurseries from which to obtain the required seedlings.

The holders of the licence shall cultivate and keep clear from undergrowth to the satisfaction of the said Officer all young trees planted as above mentioned during the continuance of their licence.

\section{Grantors Cultivate Young Trees after Expiration of Licence.}

(2) Grantors who have received any royalties prescribed by rule 40 in respect of timber felled on the lands included in a licence shall after the expiration or determination of such licence cultivate and beep clear from undergrowth to the satisfaction of and subject to the direction of the said Officer all young trees planted by the holders of the licence under sub-section (1) of this rule for a period of two years after the licence has expired or been determined.

\section{Re-planting by Forest Officers on Holders of Licences or Grantor's failing to comply with Rule $2 \%$.}

28. If the holders of a Jicence or the grantors shall fail in whole or in part to perform the conditions of the last rule which relate respectively to them, the Governor may direct any Forest Officer to perform the same on their beh $\mathrm{Il}$, and all expenses incurred in so doing shall be paid by the holders of a licence or the grantors as the case may be, within iwo months after demand for payment has been made in writing by such officer. In the event of the holders of the licence or the grantors failing to pay the expenses rayable by them in the manner aforesaid the amount shall be recoverable as a debt by the Conservator.

\section{Workmen, Payment of.}

29. The holders of a licence shall make proper arrangements for the regular payments of all labourers employed by thea or by sub-contractors who are employed by the holders to carry out the work of felling timber or getting the same out of the lands included in the licence. 


\section{Accounts.}

30. The holders of every licence shall keep correct books of accounts showing the number of timber trees felled, and shall on the days appointed for the payment of the royalties and the permit fees hereinafter mentioned render to the Provincial Forest Officer a copy of the accounts for the preceding half-year, and shall verify such accounts by affidavit of themselves or their agent. The holders of every licence shall permit the Conservator and any Forest Officer and any person appointed by the Governor for the purpose to inspect the books of acconnts and take copies thereof and extracts therefrom at all reasonable times.

\section{Transfer of Licences.}

31. The rights conferred by a licence shall not be tranferred by the holders wholly or in part or for all or any part of the period for which they are granted or renewed except with the consent of the Governor in writing.

\section{Determination of Licence on Exhaustion of Timber.}

32. If, before the expiration of the term for which a licence is granted the holders prove to the satisfaction of the frovernor that the timber within the lands included in the licence is exhausted, they may determine the same on the 30 th day of June or 31st day of December in any year by giving six calendar months' previous notice in writing to the grantors.

\section{Determination of Licence if Timber not sufficiently rorked.}

33. If at any time the Governor is satisfied that the holders of a licence are not working the timber on the lands included in their licence with sufficient diligence, he may cause the latter to be warned that they must work the timber in a more satisfactory manner, and if at the expiration of nine months from the date of such warning no sufficient improvement is in the opinion of the Grovernor shown in the manner in which such timber is being worked the Gorernor may cancel the licence, and no compensation shall in such case be payable by the grantors or any other person to the holders of the licence or to any one claiming directly or indirectly through them.

In causing such warning to be given regard will ke paid to the market prices, to the seasons, and to the manner in which timber on lands similar to those included in the licence is being worked at the time of the warning.

Such warning shall be in writing, and shall specify the various reasons which cause the Governor to be dis:atisfied with the manner in which the timber is being worked.

Determination of Licence on non-payment of Royalties or Breach of Rules, ife.

34. Upon breach of rules $19,20,21,22,23,24,25,27,29,30$ or 31 or of any special conditions or clauses in any licence by the holders thereof or in default of payment by such holders of the royalties or permit fees set forth in rules 39 and 40 within six weeks from the date fixed for the payment thereof, or if the holders of the licence shall become bankrupt or shall compound or arrange with their creditors, or suffer their effects to be taken in execution, the Governor may by notice in writing determine their licence, and any person authorised by the Governor may thereupon take possession of the lands to which licence relates, in the name of the grantors. Provided that in spite of such determivation the Governor may direct that such further action as to him may seem necessary stall and may be taken on the Bond against the hulders of the licence or against any or all of the sureties to such Bond.

\section{Liabilities to Continue after Determination.}

35. The determination of a licence under the provisions of rule 33 or 34 shall be without prejudice to the rights and remedies of the grantors against the holders of such licence for recorery of royalties and in respect of any breach of these rules which may have been committed prior to such determination.

\section{Security.}

36. The Governor shall require the grantees and the subsequent holders of every licence to give security for the payment of the royalties and duties and performance of the conditions contained in these rules and in the licence either 
(1) by a Bond with two sureties or (2) by deposit of a sum of money in the Treasury. The amount for which the Bond shall be given or the sum which shall be deposited in the Treasury shall be four hundred pounds if the area is estimated by the Conserrator at one hundred square miles or under and one thousand pounds if the area is estimated by him to exceed one hundred square miles.

\section{Seizure.}

37. Any Forest Officer or any Commissioner may himself, or by any person acting under his direction, seize any timber cut in contravention of or not marked in accordance with these rules or any order or rule made under the Forestry Ordinance, and may detain the same until the Court has given directions as to the disposal thereof.

\section{Fees.}

38. Applicants for licences shall pay the following fees :-

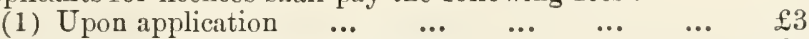
(2) Upon execution of the licence $\quad \ldots \quad \ldots . \quad \ldots \quad \ldots 5$

These fees shall be paid by stamps affixed to the application, or as the case may be to the licence.

\section{Fees}

39. Holders of licences shall pay the following fees :-

Upon each tree authority to fell which is given under rule 20 supra.

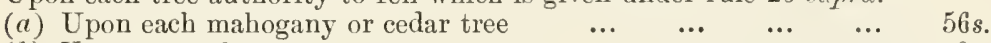

$\begin{array}{lllllllll}\text { (b) Upon any other tree } & \ldots & \ldots & \ldots & \ldots & \ldots & \ldots & 20 s \text {. }\end{array}$

Provided that such fees may be reduced by the Governor so as to permit the profitable working of the lower classes of timber.

And provided that in the event of a tree felled proving to be unsound the licensee shall forthwith notify the fact to the nearest European Forest Officer of the Province, who shall examine the tree or equse it to be examined, and if after such examination the tree proves to be unsound, and is passed as such by the European Forest Officer, the latter shall grant a certificate to that effect. upon production of which the Conservator or the Provincial Forest Officer shall grant to the licensee a rebate of forty-two shillings on the tree if mahogany or cedar, or of ten shillings if the tree be of any other kind.

\section{Disposal of fees.}

40. These fees, which include the export duties, royalties and inspection fees, shall be paid by the holders of licences to the Conservator or Provincial Forest Officer before they commence felling any of the trees authority to fell which is given under rule 20 supra, and shall be divided by the Conservator or Provincial Forest Officer as follows:-

(a) Forty-six shillings of the fee for mahogany or cedar and fourteen shillings of the fee for any other tree shall be paid into the nearest local treasury, and shall form part of the revenue of the Colony ; and

(b) Ten shillings of the fee for mahogany or cedar and six shillings of the fee for any other tree shall be paid to the Commissioner of the district in which the lands included in the licence or the greater part thereof are or is situated, and distributed by him among the grantors of the licence in the proportion to which they are entit'ed.

(c) Any rebate granted under rule 39 of these rules shall be allowed out of the fees payable under sub-rule $(a)$ of this rule, and shall be deducted from the fees payable upon the next authority to fell granted under rule 20 hereof.

\section{Penalties of Breach of Rules, ifc.}

41. If the holders of a licence shall commit any breach of any of these rules (including the clauses or conditions contained in the licence) they shall be liable to a fine not exceeding fifty pounds or to imprisonment for any period not exceeding six months with or without hard labour, and in addition to such fine or imprisonment the licence may be determined. 


\section{Form of licence.}

42. Licences may be in the form giren in the Appendix to these rules and all conditions and clauses in any licence (whether in such form or not) shall be regarded for all purposes as being prescribed by these rules.

\section{Reservations.}

43. Notwithstanding the grant of a licence under these rules there shall be reserved :-

(a) A right on the part of the grantors to fell or cut, with the Conservator's consent, any trees for their own domestic uses and not for sale or barter.

(b) A right on the part of the Government with the consent of the grantors of the licence to fell any trees when required for the construction or repair of Government buildings or works.

\section{Conditions upon wilch Owates of LANDS MaY Cut Timber.}

$$
\text { For export. }
$$

44. The owner of any lands in a district desiring to fell trees for export shall before commencing work :-

(1) Settle with the nearest Commissioner or European Forest Officer a hammer mark to be made on all timber coming from his lands ; and

(2) Mark with such mark all trees which he desires to fell, and prepare a list in duplieate of snch trees, giving the particulars set forth in paragraphs $(a),(b)$ and $(c)$ of rule 20, and forward the same to the nearest Commissioner or European Forest Officer, who shall authorize the felling of such trees in the manner and upon and subject to the provisions of the said rule 20, and subject to the payment of the fees prescribed by paragraph (3) of this rule. The hammer mark settled as herein provided shall be entered in the register to be kept by the Conservator, under rule 14 hereof.

(3) The owner of lands shall pay in lieu of export duty and inspection fee the following consolidated fees upon each tree authority to fell which is given under rule 20 supra.

(a) Upon each mahogany or cedar tree $\quad \ldots \quad 46 s$.

(b) Upon any other tree... $\quad \ldots \quad \ldots r \quad \ldots \quad 14 s$.

Provided that the Governor may reduce the latter fee so as to permit the profitable working of the lower classes of timber. These fees, which include export duties and inspection fee, shall be paid to the Conservator or Provincial Forest Officer by the owner of lands before he commences felling any of the trees authority to fell which is given under rule 20 supra and shall be paid into the nearest local Treasury and shall form part of the revenue of the Colony.

\section{For local use.}

45. The owner of any land or any person with the consent of the owner may fell trees thereon if the same be not for export but for sale as timber for use locally.

$$
\text { Fees. }
$$

The following fees shail be paid for each tree felleả under the provisions of this rule.

The owner or other person shall pay for each tree felled

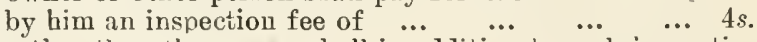

Any person other than the owner shall in addition to such inspection fee pay as royalties for the owners :-

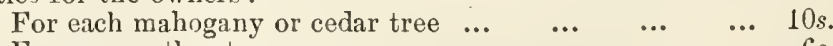

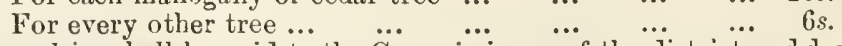

Such royalties shall be paid to the Commissioner of the district and dealt with by him according to the provisions of section (b) of rule 40 hereof.

The owner or other person desiring to fell trees under this rule shall before doing so comply with the requirements of sub-rules 1 and 2 of rule 44 hereof, except as regards the payment of fees provided by sub-rule 2 thereof. 


\section{Re-planting by Owners of Lands.}

46. The provisions of rules 27 and 28 relating to re-planting shall apply to owners of land felling trees, provided that such owners as fell trees for export shall not be compelled to cultivate and keep clear from undergrowth young trees planted by them after such young trees are four years of age.

\section{Certain Rules to Apply to Owners of Lands.}

47. The provisions of rules $21,23,25,26,37$ and 41 shall apply to owners of lands taking timber for the purposes aforesaid and to the timber taken by them as if they were holders of licences granted under these rules.

\section{Miscellaneous.}

\section{Cutting of Timber for Local Use.}

48. On native lands in respect of which no licence has been granted under these rules, such timber as may be required locally for domestic, agricultural or other like purposes or for the construction or repair of canoes, vessels, buildings, bridges, tramways, railways or other like works but not for purposes of sale may be felled by the owners of the lands or by any persons autborized by them, provided the consent of the nearest Commissioner or European Forest Officer be first obtained.

\section{Procedure for Receiring of Amount Due on Bond.}

49. In any proceedings which are taken on a Bond required to be given in accordance with these rules the amount due and recoverable in such proceedings shall be the amount (not exceeding that named in the Bond) which the Conservator may fix as and for liquidated damages.

\section{Duties of Chiefs and Grantors interested in a Licence.}

50. The Chiefs or grantors interested in a licence shall assist the Forestry Department in the work of inspection and sball report to the nearest European Forest Officer any instance in which any of these rules or any rule or order made under the Forestry Ordinance has been broken.

If the Chiefs or grantors fail in the fulfilment of this duty the Conservator or Prorincial Commissioner may recommend that the royalties due or becoming due to such Chiefs or grantors sball be paid into the gentral revenue of the Colony or to any Chief or grantor who has rendered raluable assistance to the Forestry Department, and the Governor may make an order to that effect accordingly : Provided that not more than one year's royalties shall be forfeited under this rule for any one failure.

\section{Application of Rules.}

51. These rules shall apply to all Crown lands and lands leased by the Crown, and to Native lands: Provided that they shall not, without the consent in writing of the parties interested, apply to any concession zranted before the rules came into force; but all such concessions shall be regulated by the rules in force at the time of the granting thereof.

\section{Appendix.}

\section{Timber Licence.}

Tils INDenture made the day of , 19 , BeTwEen of Grantors and their successors in title) of the one part and cereinafter successors in title) of the other part : 
WHEREAS the Licensees have given security by Bond for the performance of the conditions subject to which this licence is granted in the sum of

Now thHS INDENTURE WITNRSSETH :-

1. The Grantors hereby grant to the Licensees the sole and exclusive right to take on the lands situated at through the centres of the trees marked bounded by a line drawn at the limits of the said lands, which lands are delineated and surrounded with a red border line on the plan attached hereto, from the day of , 19 , for a term of five years, provided that after the expiration of the said term of five years the Licensees sball be entitled to renew the licence hereby granted for periods of two years in accordance with and upon and subject to the conditions set forth in the rules printed on the back hereof and upon and subject to such special conditiuns if any as the Governor may prescribe.

2. The Licensee; shall pay the royalties, and exercise the right hereinbefore granted upon and subject to the conditions set forth in the rules aforesaid.

(Here insert special clauses and conditions, if any.)

IN WITNESS WHEREOF the said parties have hereunto set their hands and seals or made their marks and set their seals the day and year first above written.

The above parties set their hands or made their marks and this Indenture was sealed and delivered in the presence of

Commissioner.

Assented to on behalf of the Government of Southern Nigeria this day of , 19 .

\section{Provincial Commissioner.}

Kules $2,7,19$ to 35 inclusive, and 37 to 44 inclusive shall be printed on the back hereof.

\section{Rulies relating to Forest Reserves.}

\section{A.-Prohibitions.}

The following acts are prohibited except in so far as they may be expressly sanctioned in the deeds constituting the reserves, or by the rules and regulations hereinafter set forth.

(1) The felling, tapping, barking or taking of any plant or the produce derived from it.

(2) The taking of earth, soil, stone, rock or minerals.

(3) The digging, cutting and turning over of soil.

(4) The lighting of fires, or smoking within specified areas (to be notified in the Gazette), at any time between 1st December and 30th April.

(5) The hunting, trapping, snaring and catching of beasts, birds or fish, the poisoning of water, and the use of any explosive for the purpose of killing fisl.

(6) The construction of dams or weirs across rivers or streams, and the obstruction of the channel of any waterway.

(7) The erection of any building.

$$
\text { B.-Fules and Regulutions. }
$$

1.-(1), (2) and (3) The acts prohibited may be allowed provided that a licence be obtained from the Provincial Forest Officer authorizing the same, and the conditions prescribed by the said licence be observed, and the fees paid as prescribed therem.

These prohibitions and provisions do not apply to lands let out for farming purposes as hereinafter provided.

(4) The lighting of fires within the prescribed period may be allowed provided that:-

(i) Due notice is given to the nearest Forest Officer.

(ii) The area immediately surrounding the spot where the fire is lit is sufficiently fire-traced to prevent the spread of fire to the adjoining areas.

(iii) In the case of villages or farms situated within the reserre, such villages and farms are sufficiently fire-traced to prevent the spread of fire to the adjoining portions of the reserve. 
(iv) In the event of any fire breaking out in the reserve, the inhabitants of any village or farm situated within the reserve are liable to be called out by any Forest Officer to help to extinguish the fire.

Smoking is prohibited except withiu areas that are sufficiently firetraced to prevent the spread of fire from such area to the adjoining portions of the reserve.

(5) Hunting and fishing withiu a Government reserve may be allowed provided that :-

(i) Such hunting or fishing is carried out in accordance witl conditions specified on a hunting or fishing licence, and that the prescribed fees for such licences are paid.

(ii) Such licences may prohibit altogether the hunting of amy or all animals or birds during certain seasons of the year, as, for instance, when fires are prevalent or during the breeding season, and may prohibit altogether the hunting of certain specified animals or birds.

Animals and birds so protected within reserves will be notified from time to time by publication in the Gazette.

In the case of fishing licenees, similar restrictions may be imposed.

Hunting or fishing licences may be obtained from the Provincial Forest Officer.

(6) Buildings or similar structures may be erected in reserves provided that :-

(i) Such buildings or structures are erected in accordance with the conditions of a licence and the payment of any fees prescribed by such licence.

(ii) The erection of villages in a reserve or farming may be allowed free of any fees if the inhabitants of such a village-

(a) Agree to plant up the farm lands allowed them when the latter have reached the fallow stage with any plants that the Conservator or Provincial Forest Officer may require to be planted out.

(b) Tend the young plants so planted out for such a period as the Conservator or Provincial Forest Officer may direct.

(c) Limit their farming operations to such areas as may from time to time be set aside for that purpose by the Provincial Forest Officer.

(d) Fire-trace their villages and help to put out any fires that may occur within the reserves.

A breach of any of the above conditions will render the inhabitants of the village liable to expulsion from the reserve.

2. The forms contained in the Appendix hereto shall be used as far as they may be applicable, and the fees shall be paid according to the rates set forth in the said licences, or according to rates which may hereafter be fixed by order made under section 19 of the Ordinance and published in the Gazette.

3. Whoever shall commit a breach of any of the provisious hereinbefore contained shall be liable upon conviction thereof to a penalty not exceeding 507 . or to imprisonment for a term not exceeding six months.

\section{APPFNidix.}

Licence Forms.

Fons $\Delta$.

Licence to collect. Major Forest Produes (Timber).

Permission is granted to [name of person] of [his resideme] to fell and take the timber procured from [number of] trees of the following kinds [mter number of each. lind to be folled] situated within the limits of block or compartment [number or name of block or compartment] of the [name of ] rescrve during the period [date of issue of licence] to [date of expiration of licence] on the following conditions :-

(a) That only such trees arc felled as lave heen marked by Government for that purpose. 
(b) That the following fees are paid at the rates indicated below for the different species and sizes on issue of this licence.

Rates:-

(c) That the felling of the trees is carried out with due care to prevent unnecessary damage to the young growth.

(d) That the timber is extracted along such lines of export within the limits of the reserve as the Provincial Forest Officer may direct hereon.

Date. [Lines of export to be utilized.]

\section{Signature \\ Forest Officer.}

\section{Form B.}

\section{Licence to collect and take Minor Forest Produce.}

Such as flowers, fruit, leaves, branches, bark, roots, fibres, dyes, gums, resins, subber, ashes and such other produce derived from plants as may be entered nereon.

Permission is granted to of to collect and take [name of produce] from [species of plant] situated in compartment or block of the reserve to the amount of [enter number of plants utilized or quantity of produce to le extracted] during the period to on the following conditi ns :

(a) That the following fee of is paid for [number of plants or lbs. weight or bundles or basket] the above produce at the rate of per [plant, bundle, lb. or basket, load, $d c$. .] on the issue of this licence.

(b) That only such plants are utilized for the collection of the produce as may be marked or otherwise set apart by the Forestry Department for that purpose.

(c) That the produce is collected in accordance with the instruetions entered on the back of the licence and is transported along such lines of export within the limits of the reserve as the Provincial Forest Officer may direct.

\section{FORM C.}

\section{Licence to hunt within a Reserved Forest.}

Permission is granted to reserve during the period

(a) That a fee of

of

to to hunt within the on the conditions mentioned below :

(b) That animals and birds of the following species are not to be shot or otherwise killed by the licensee.

Species

(c) That the following species of birds and animals only the number and sex, given below can be killed.

Species sex number to be killed.

\section{Form D.}

\section{Licence to Fish within Reserved Forest.}

Similar to above, but provide for restrictions as to season, and prohibit the use of poisons, nets and explosives. 
PL. 1.

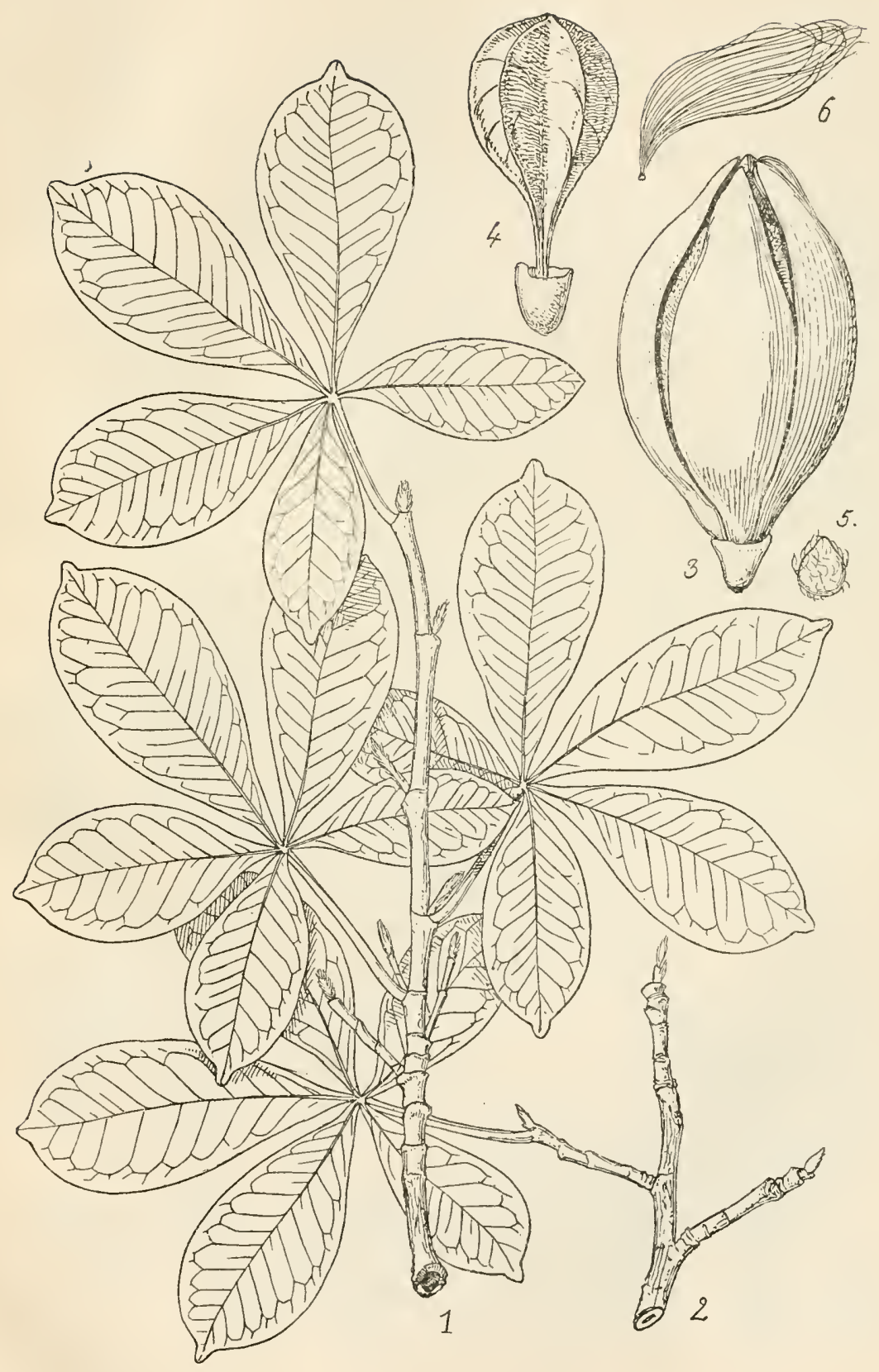

BOMBAX BREVICUSPE. 
PL. ‥

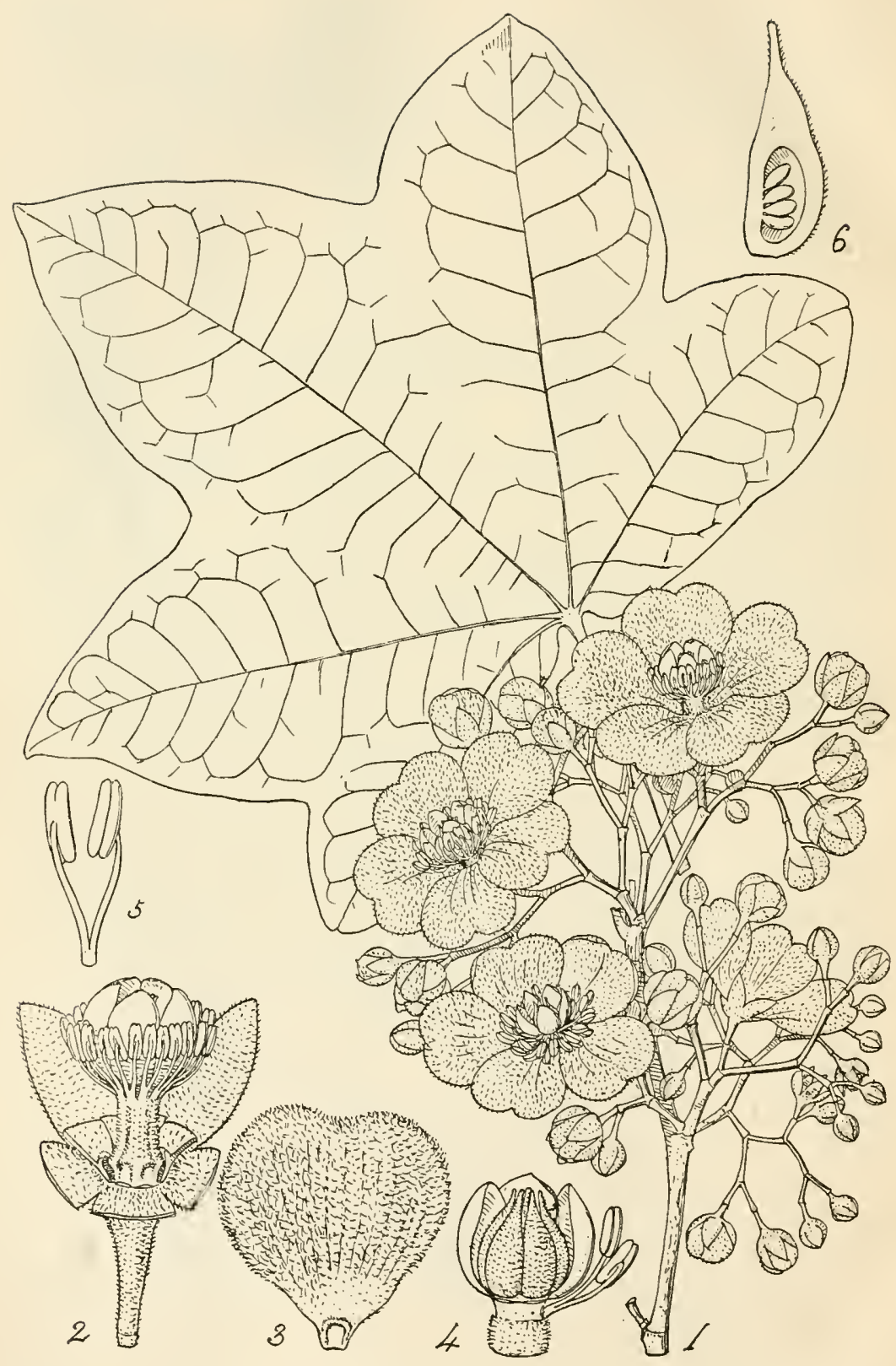

Triplochiton JoInsGnil. 
PL. 3.

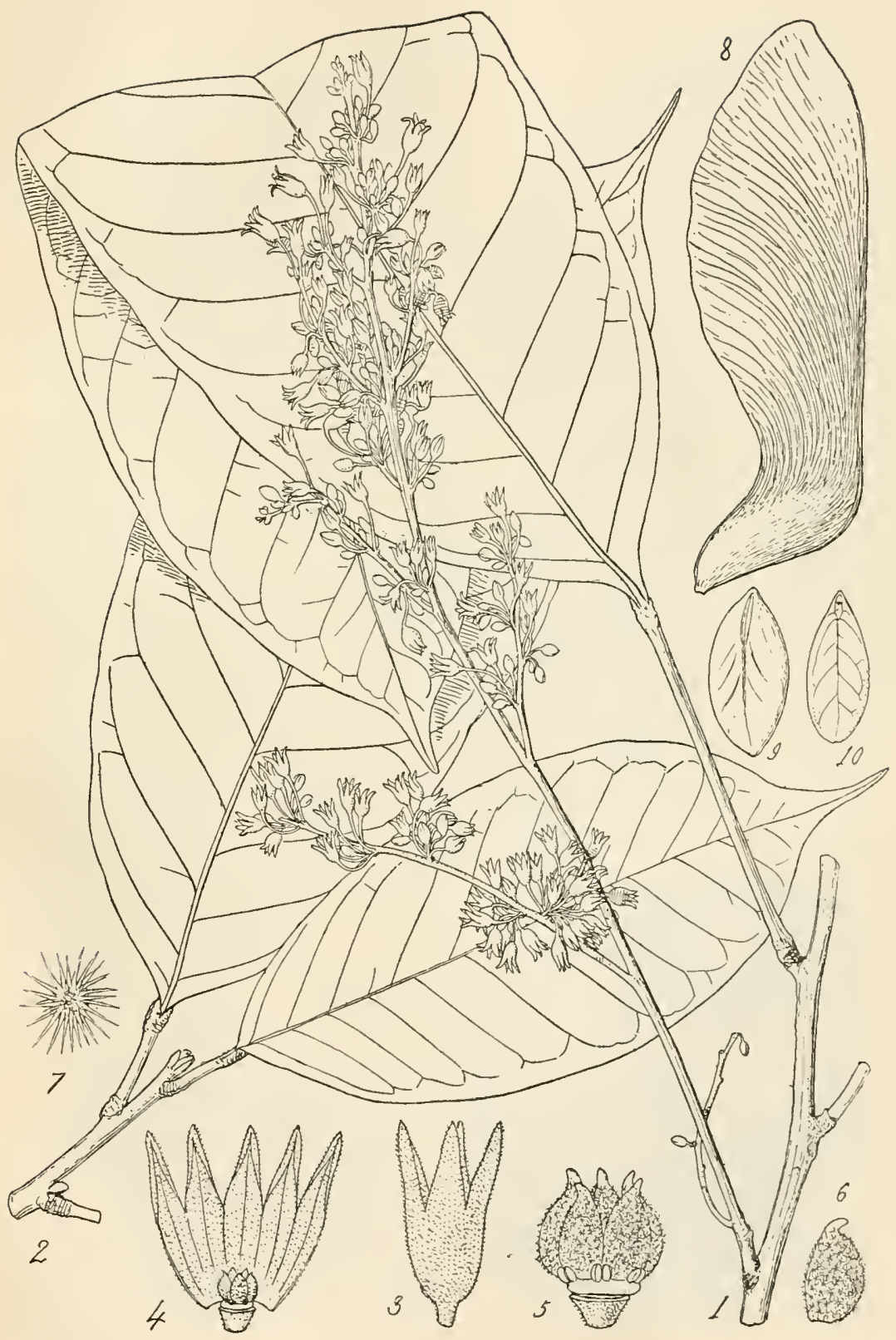

HERITIERA [TILIS.

12315 
PL. 4.

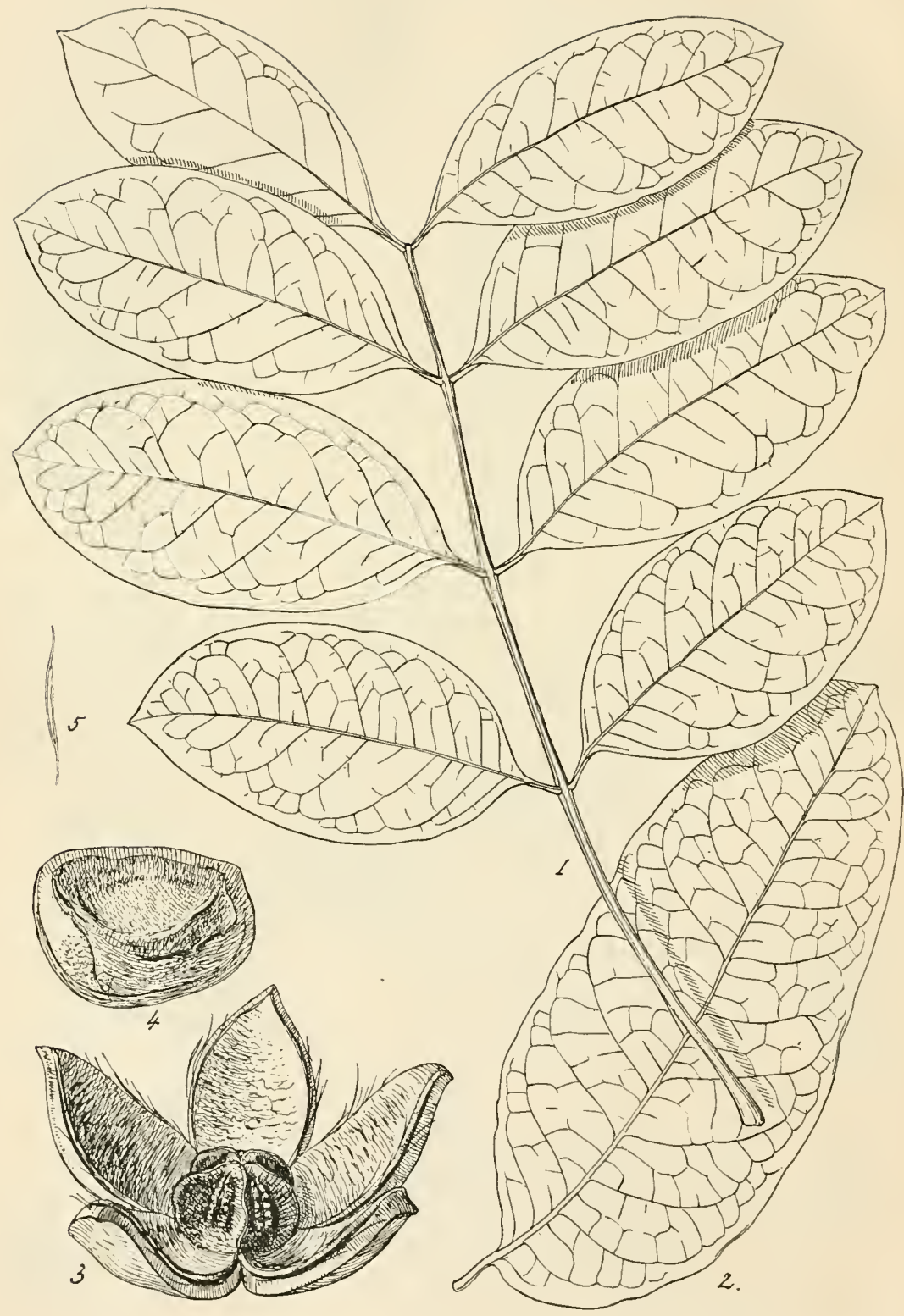

KHAYA aNTHOTHECA. 


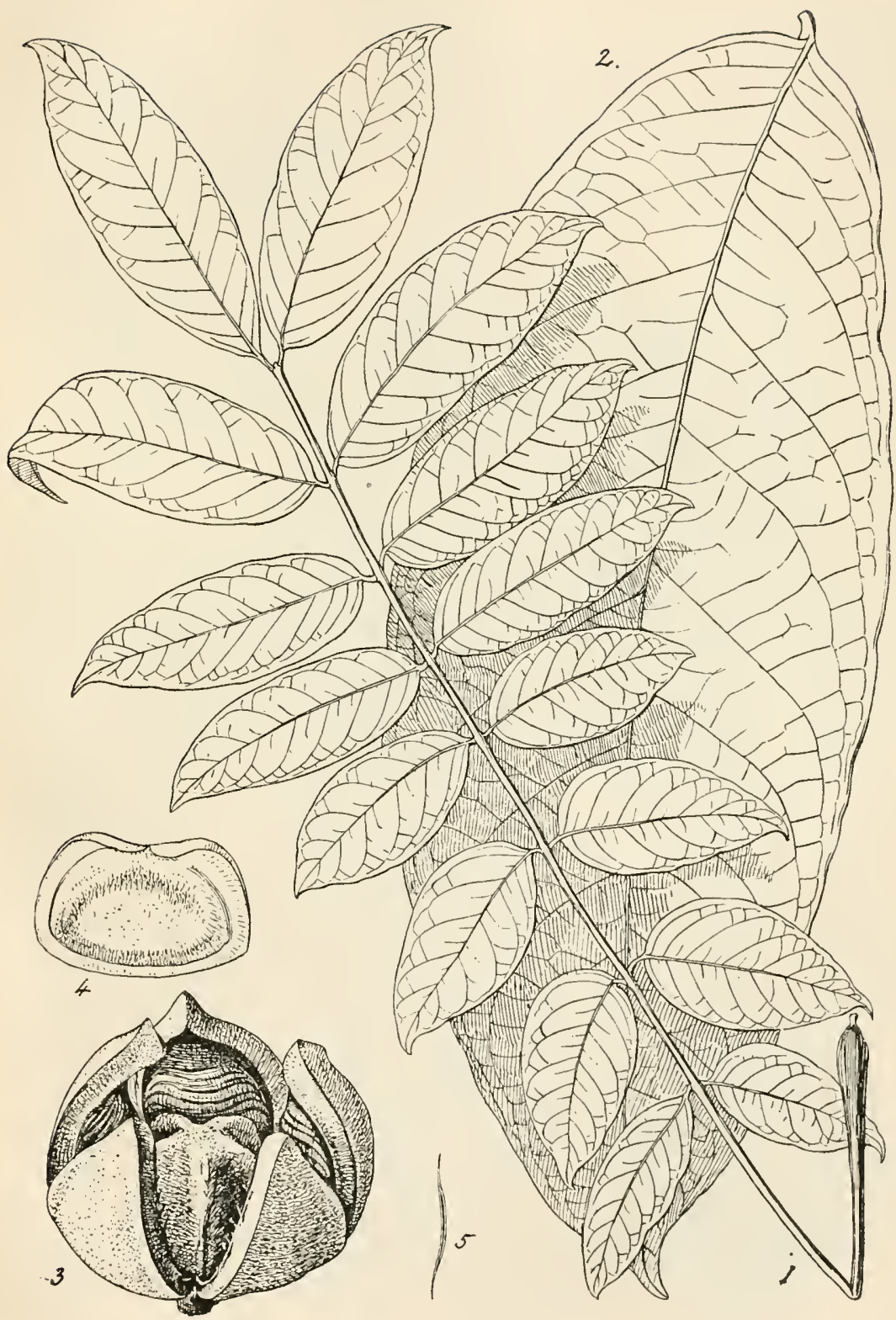

KHAYA GRANDIS. 
PI. 6.

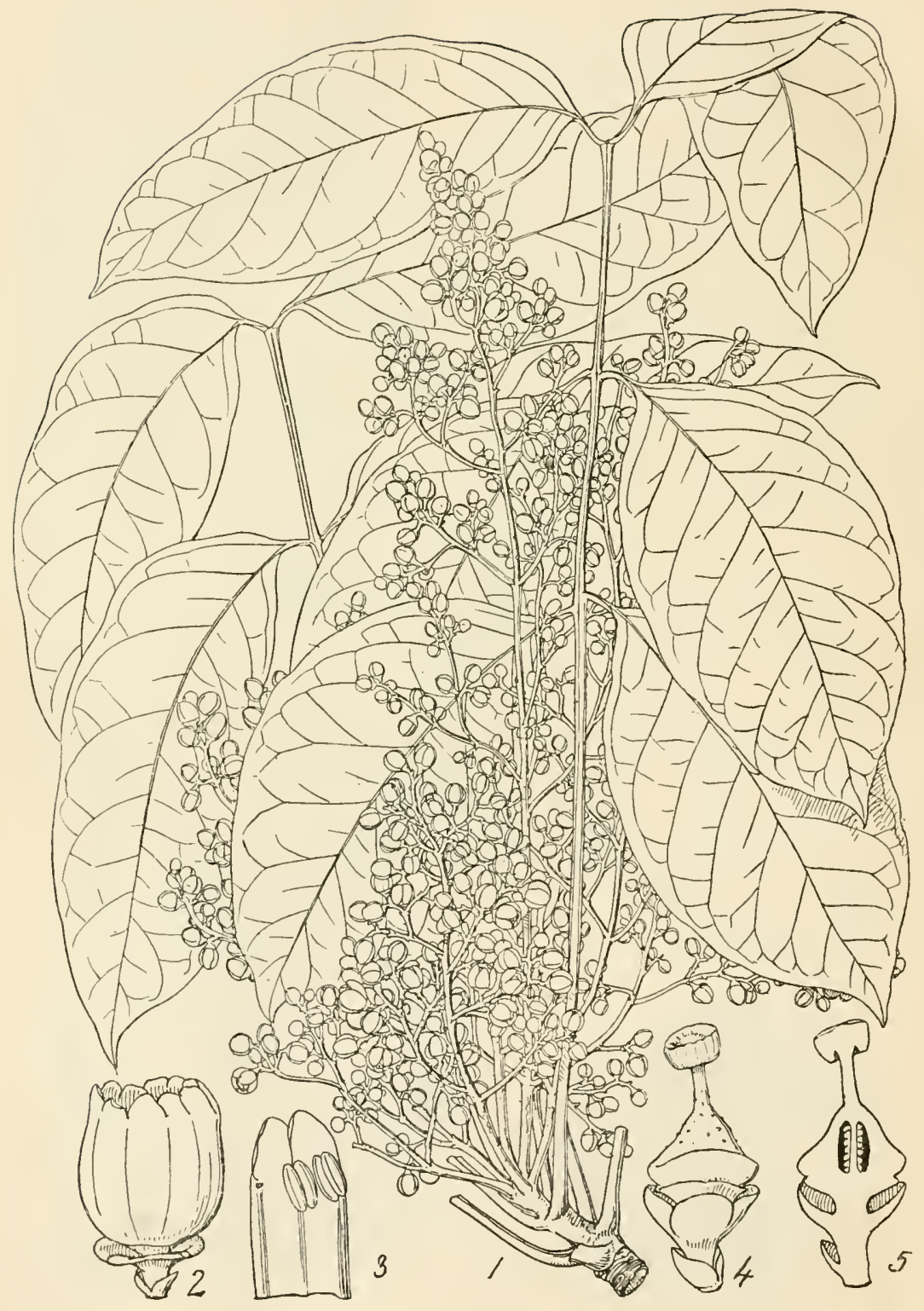

Kmaya Punchif. 
P.. 7.

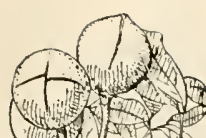

(4) 1 1) 10

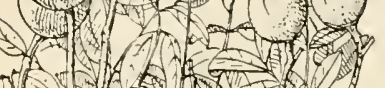

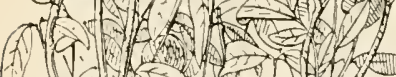

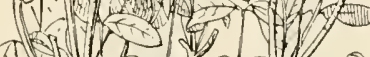

11)
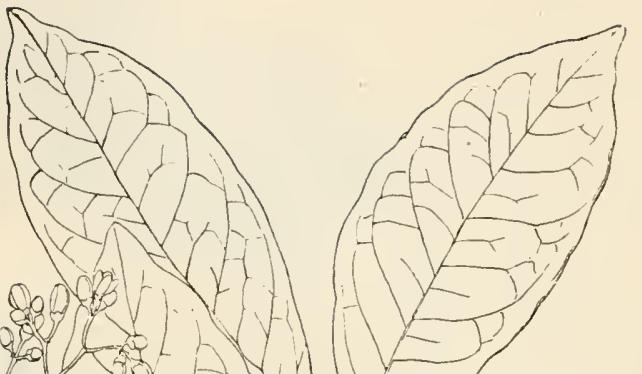

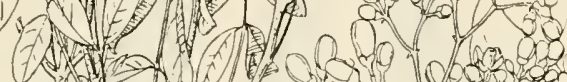

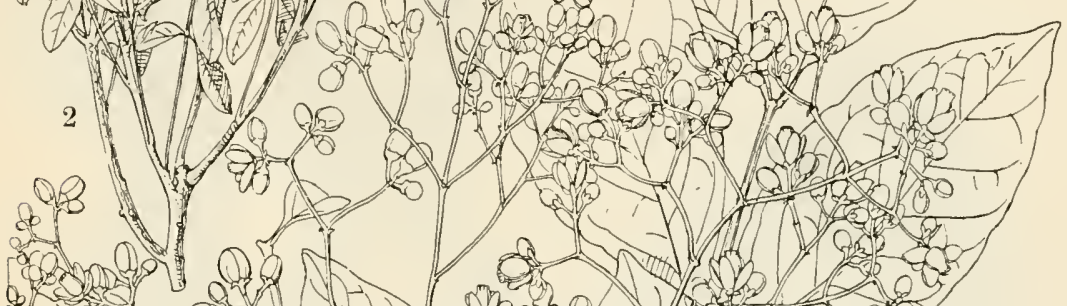
Q90 Q9 -

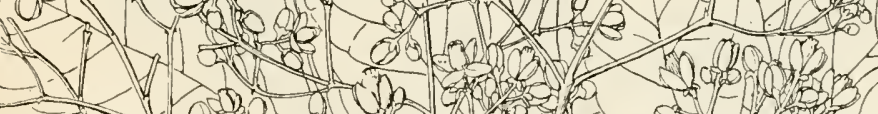

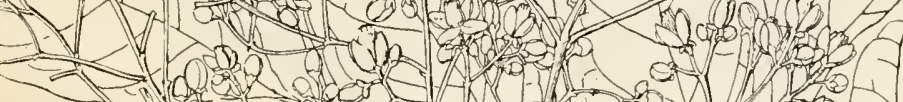
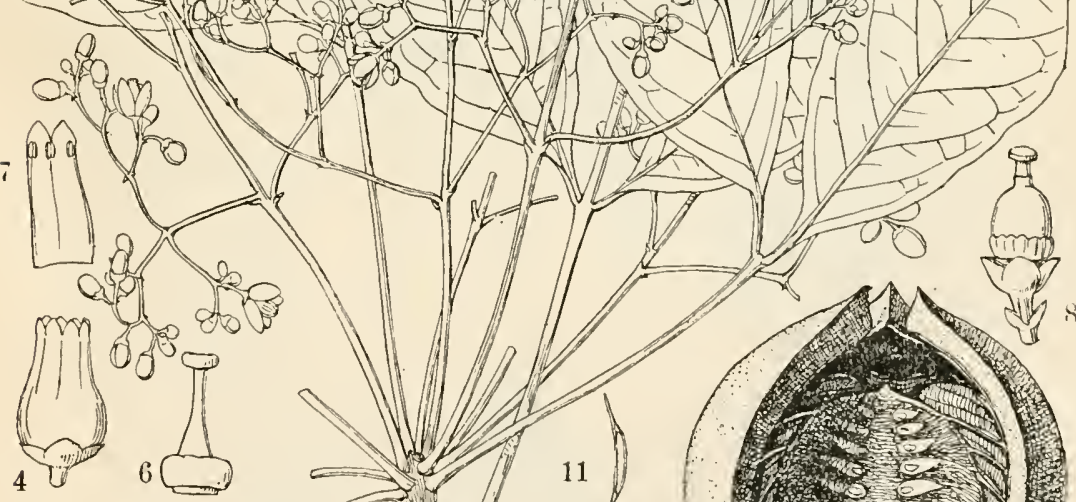

$\underbrace{(14,1)}_{3} 909$
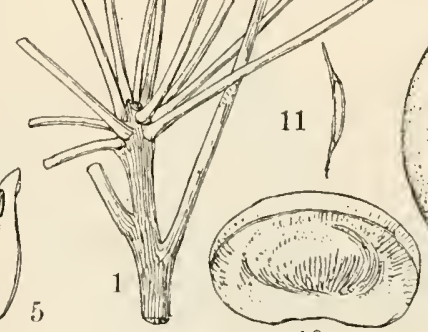

10 
PL. 8.
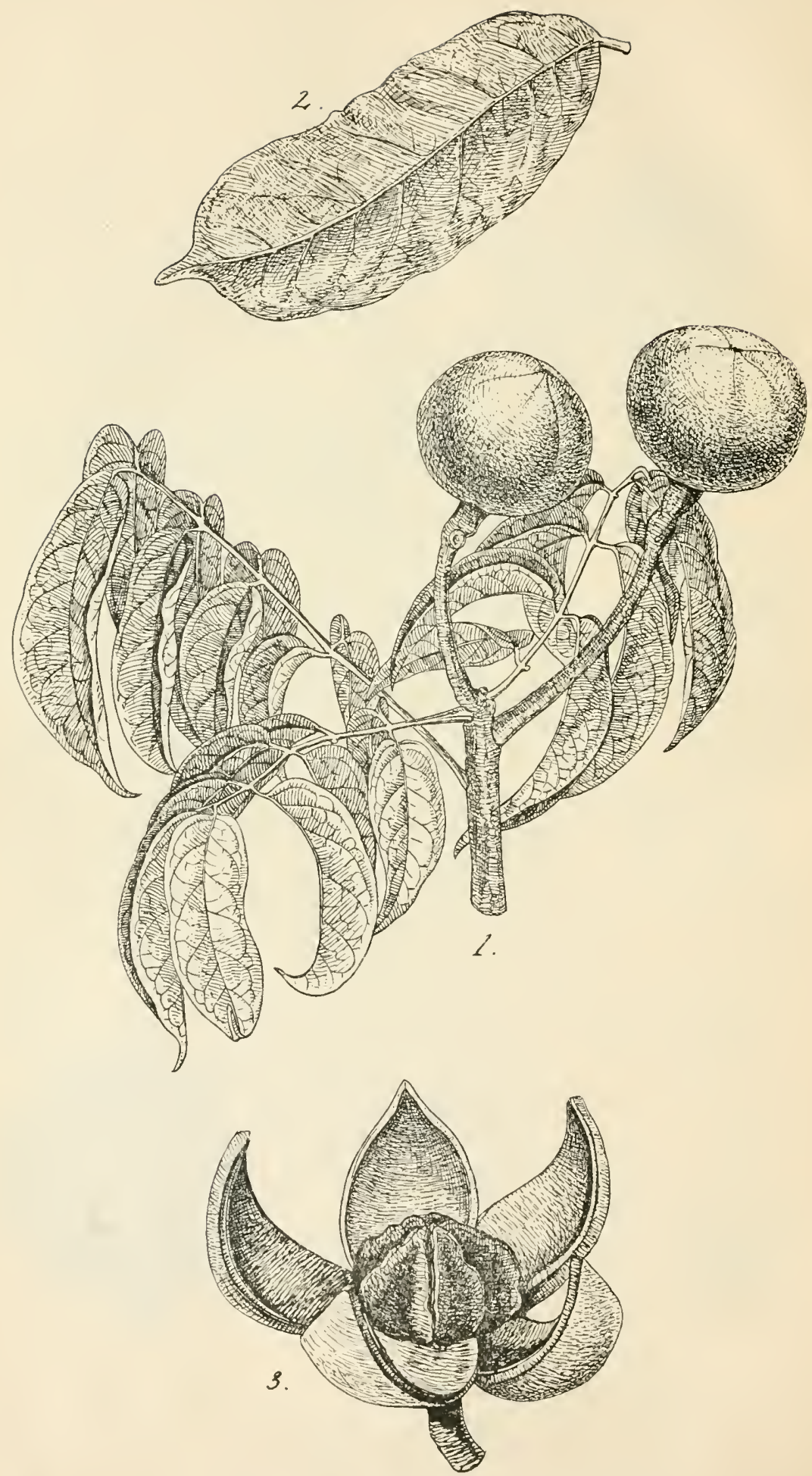

Khaya Sp. (The "Dubini " of the Fantis). 


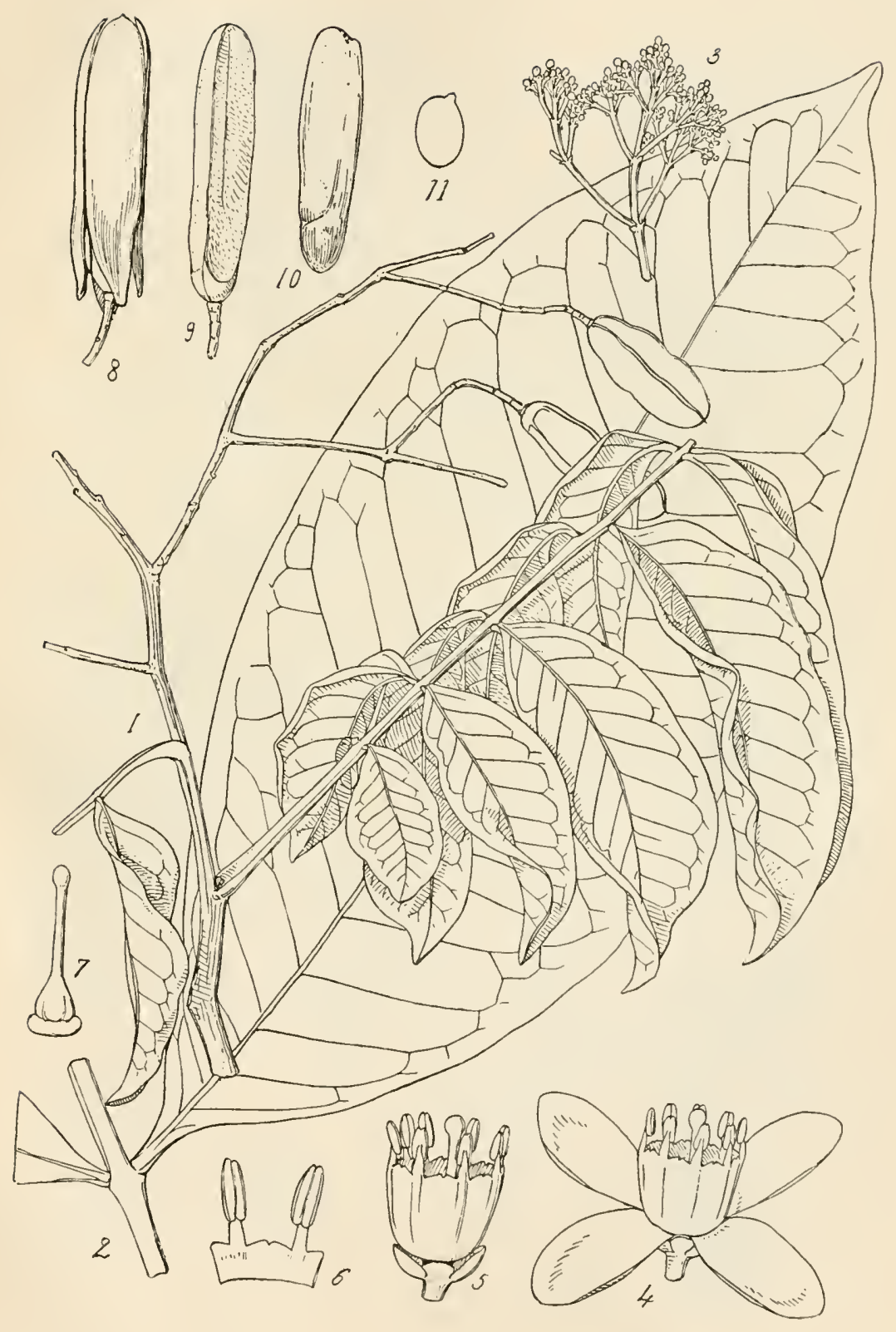

Lovod KLatneava. 
Pl. 10.

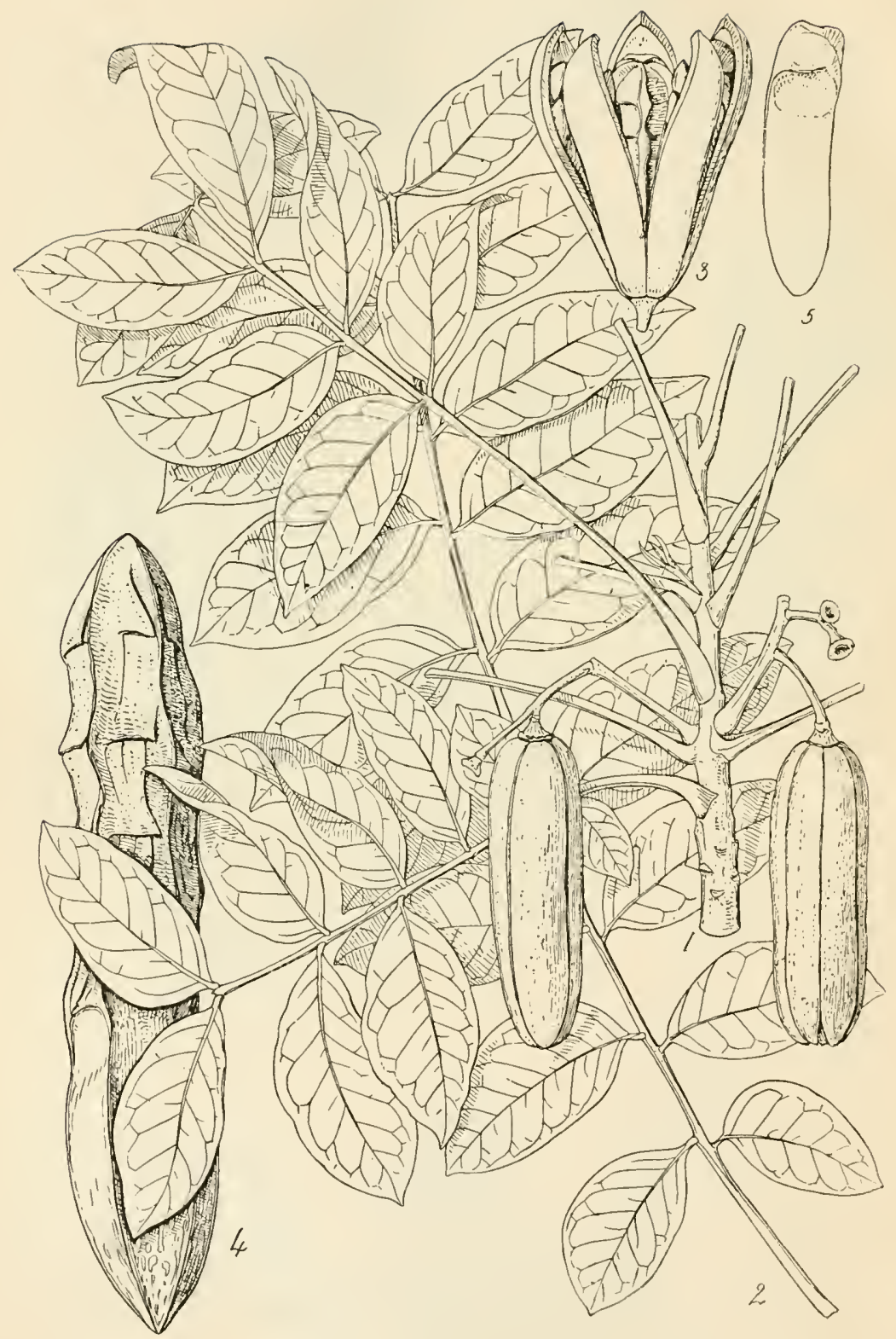


Pl. 11.

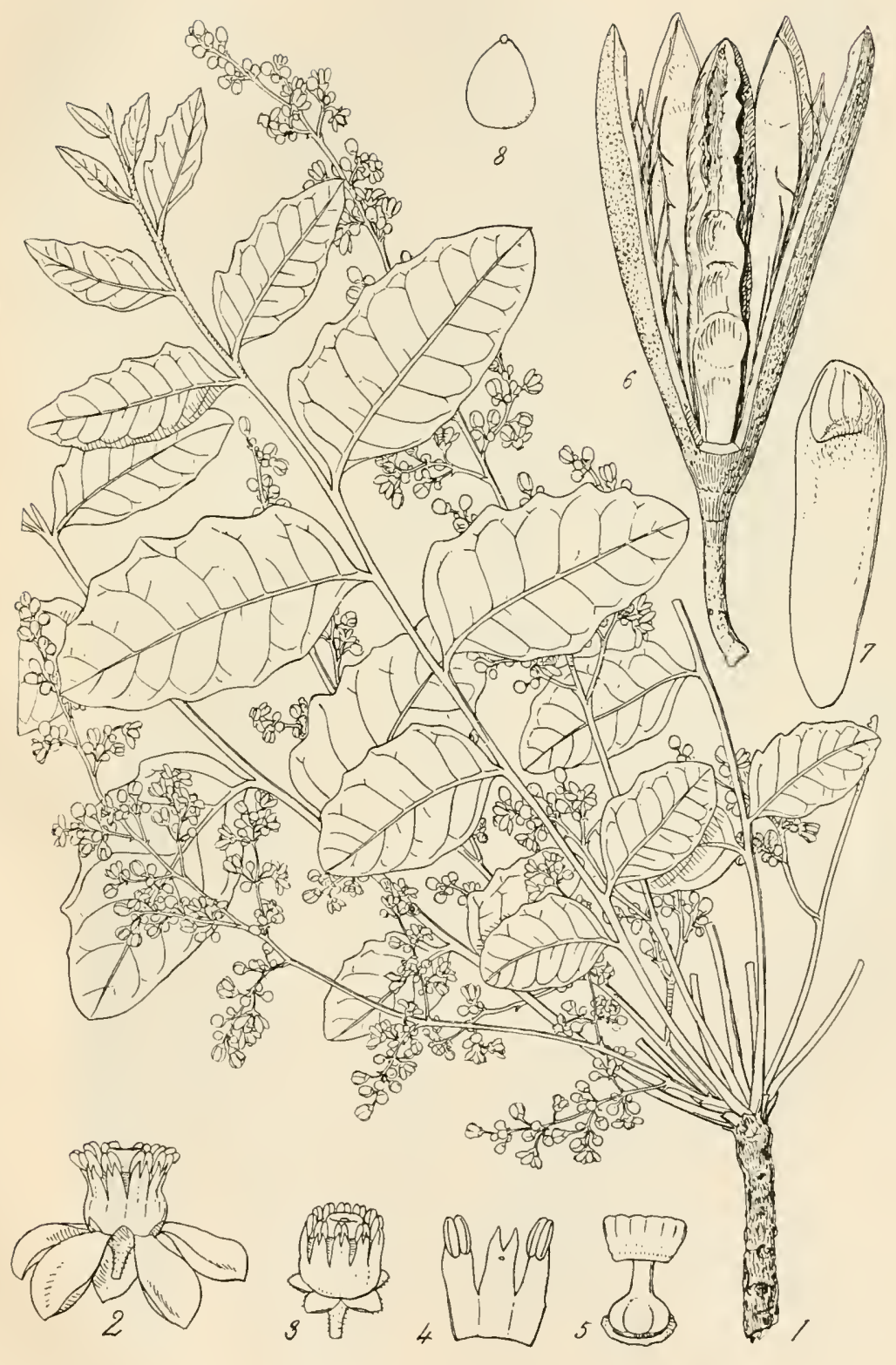

Pseunocedrela Kotschy 


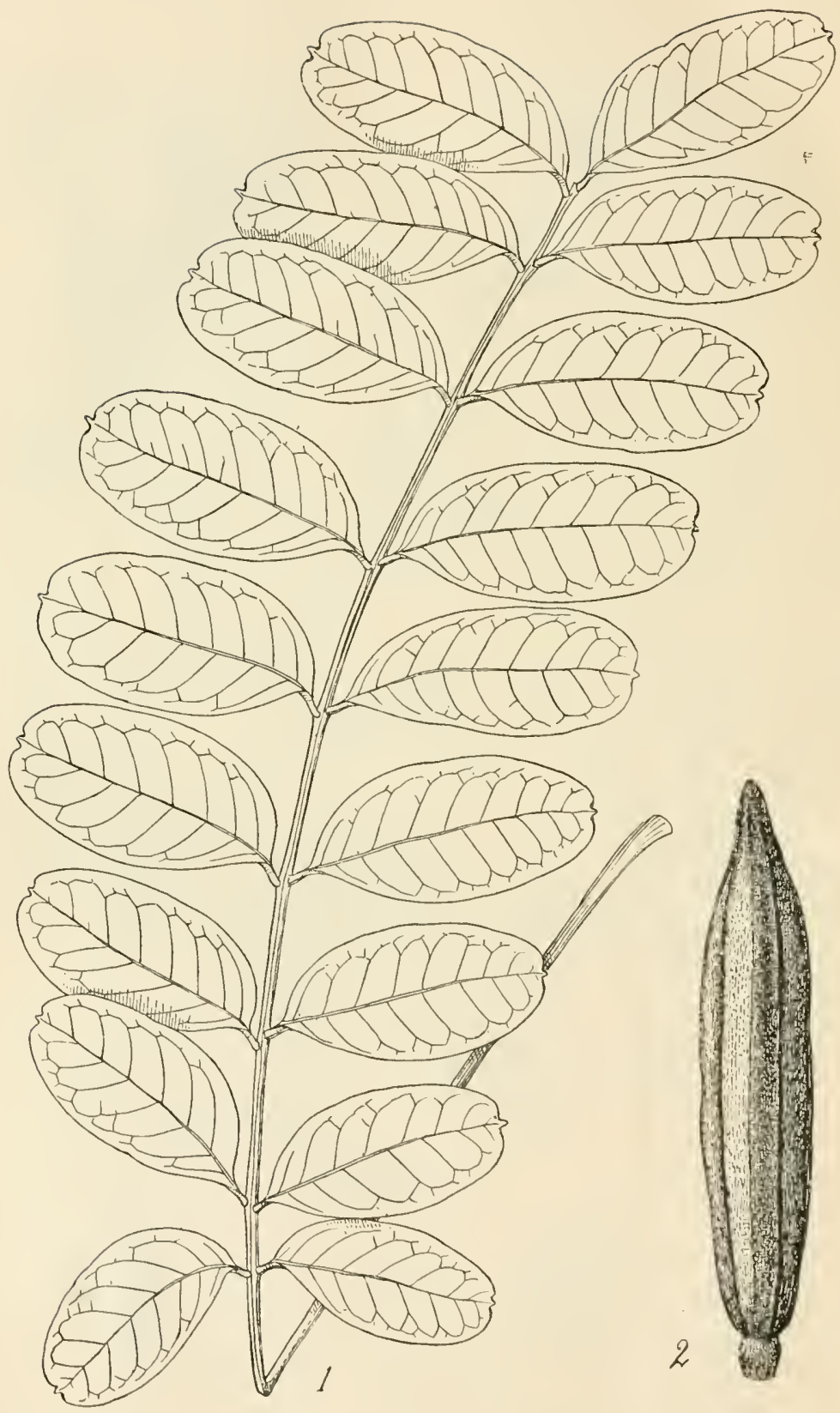

Pseudocedrela sp. (Near P. Cylindrica). 
P'L, 13 ,

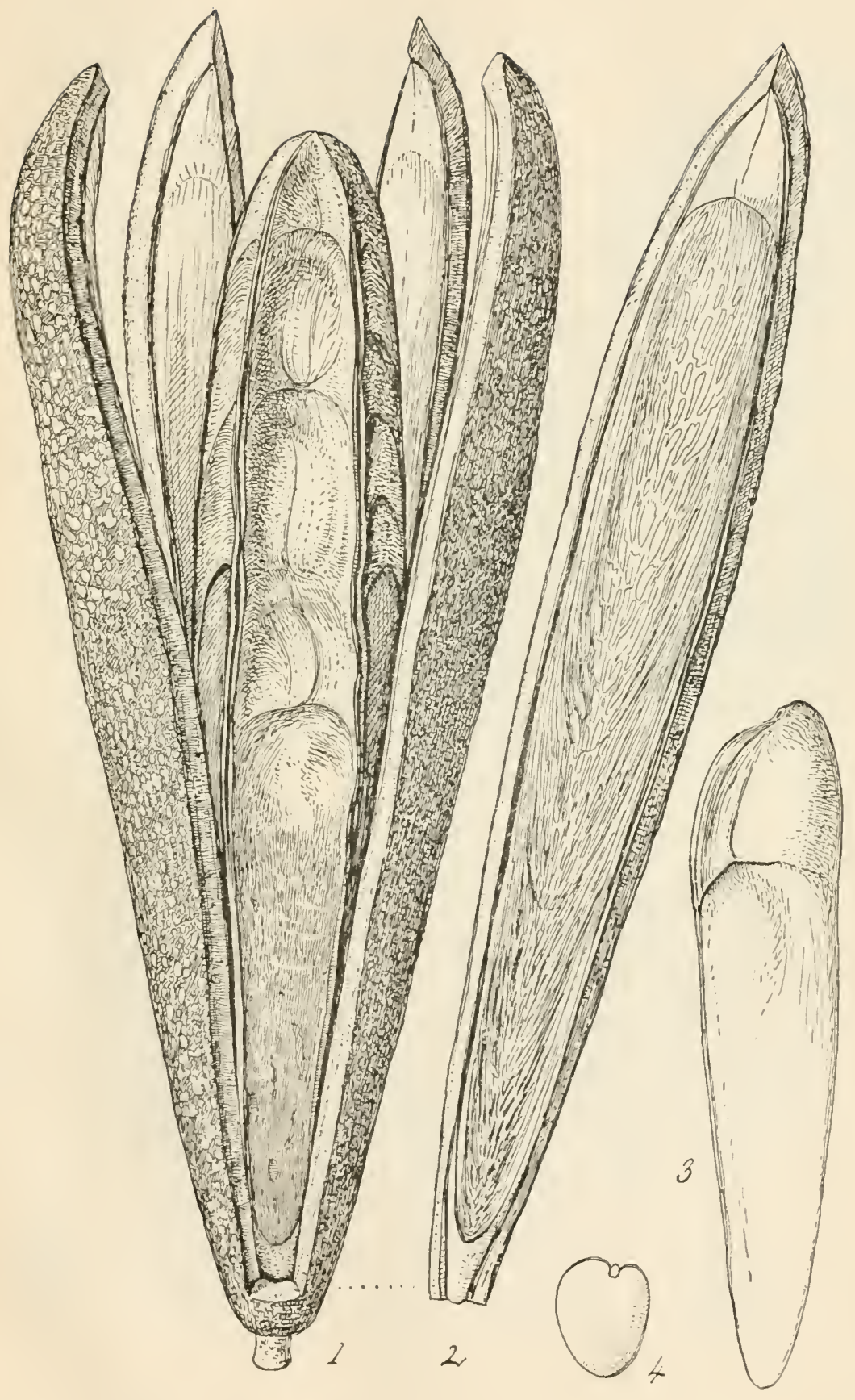


PL. 14.

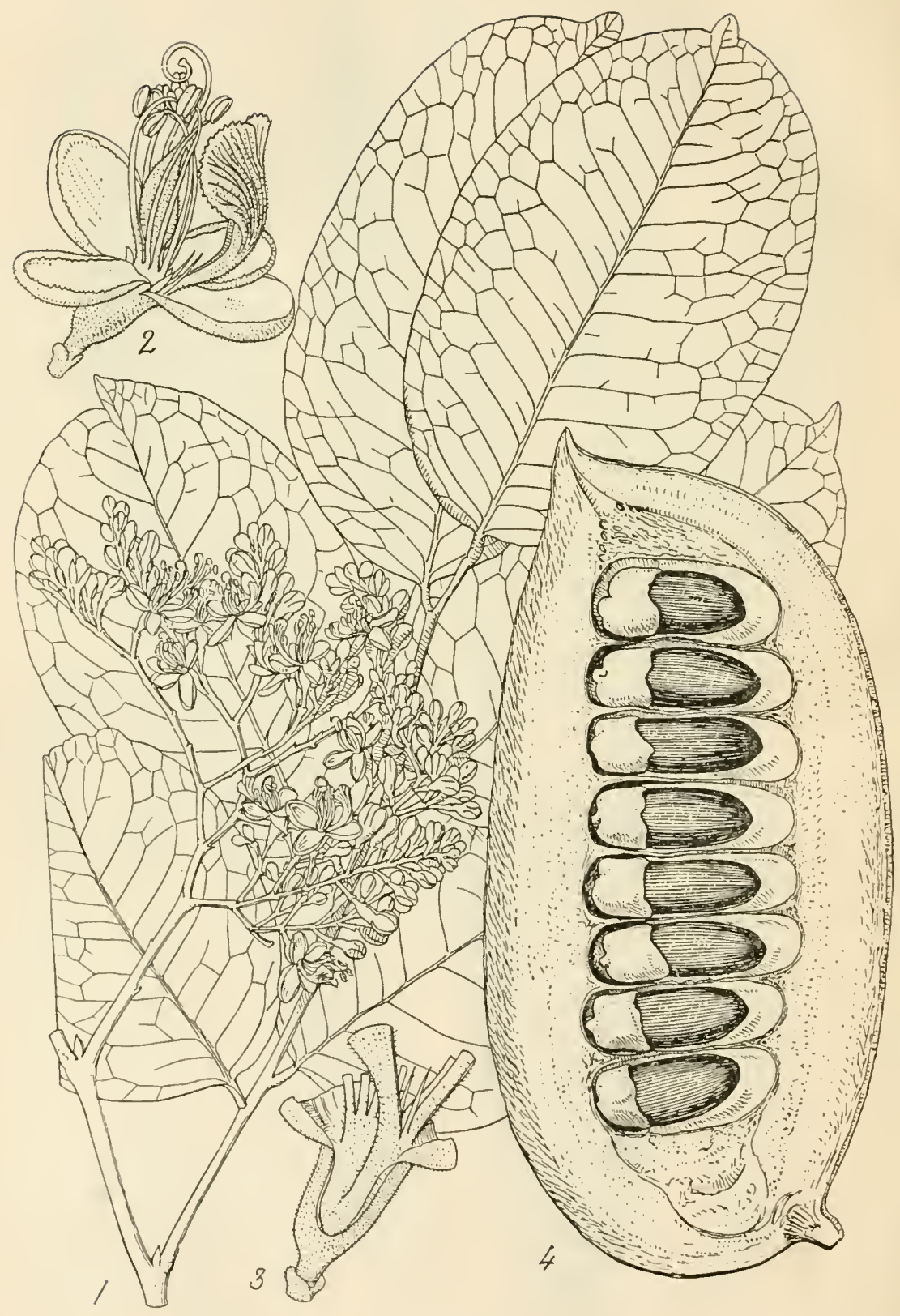




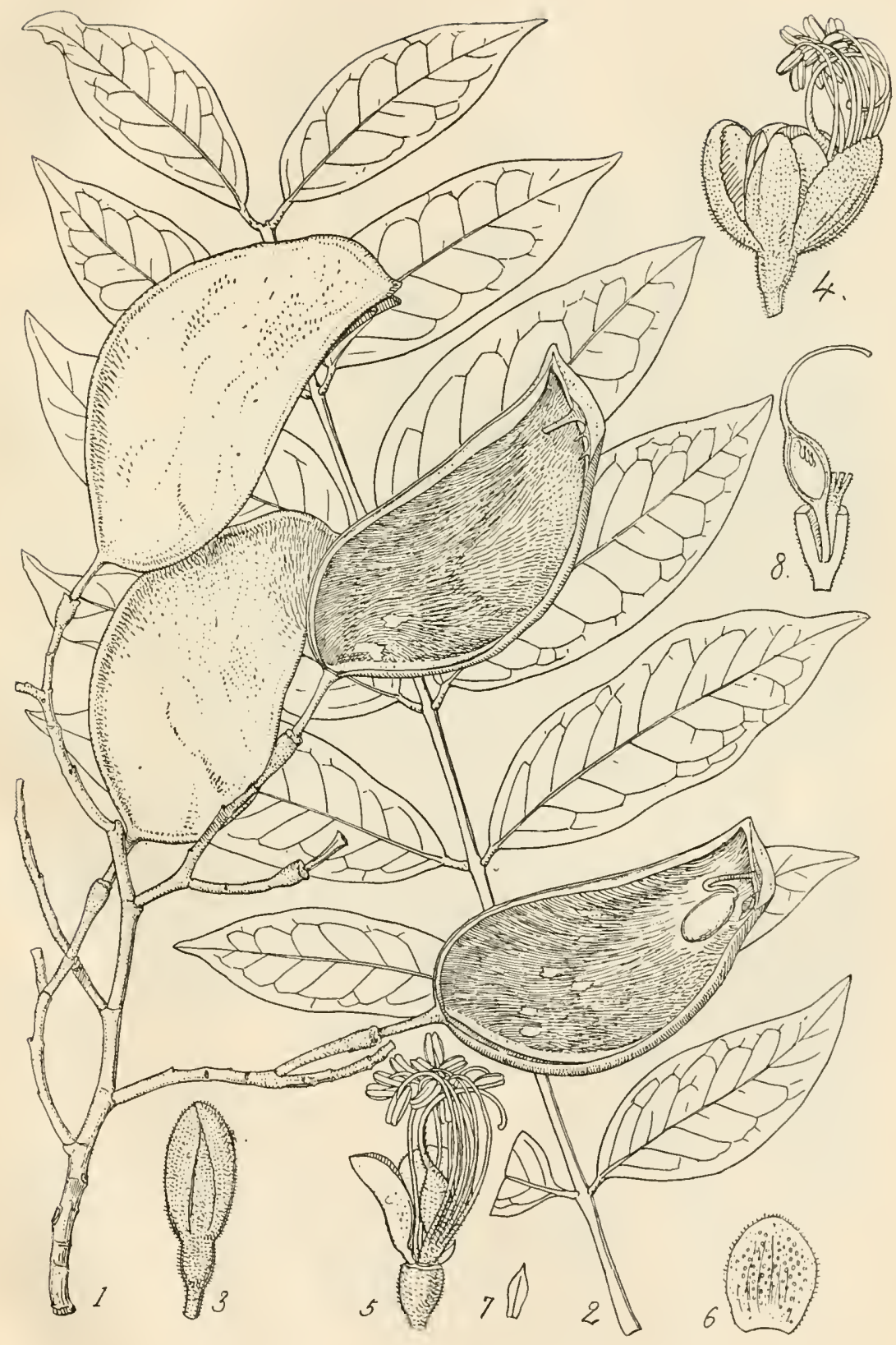


PI. 16.

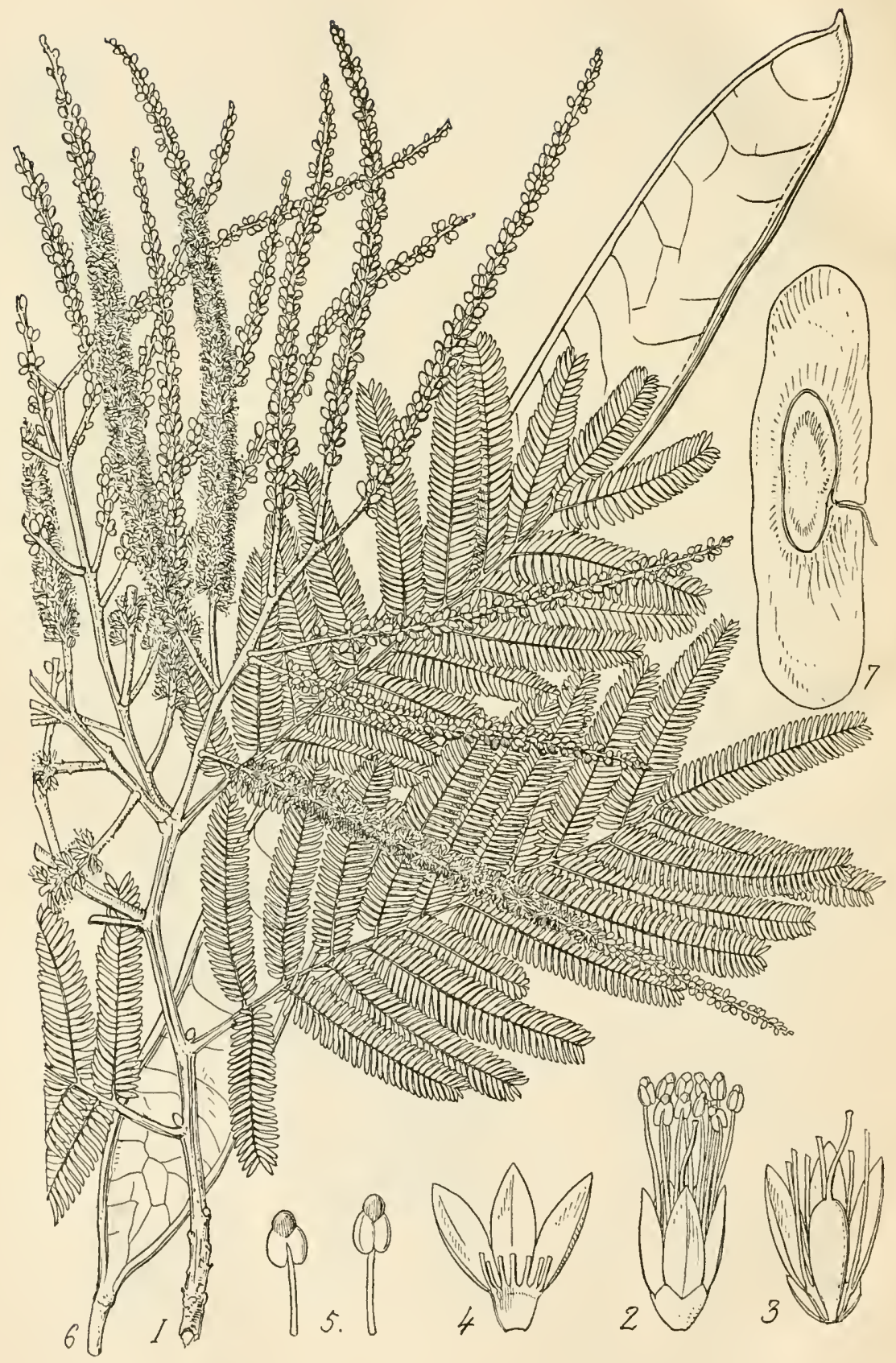


PL. 17.

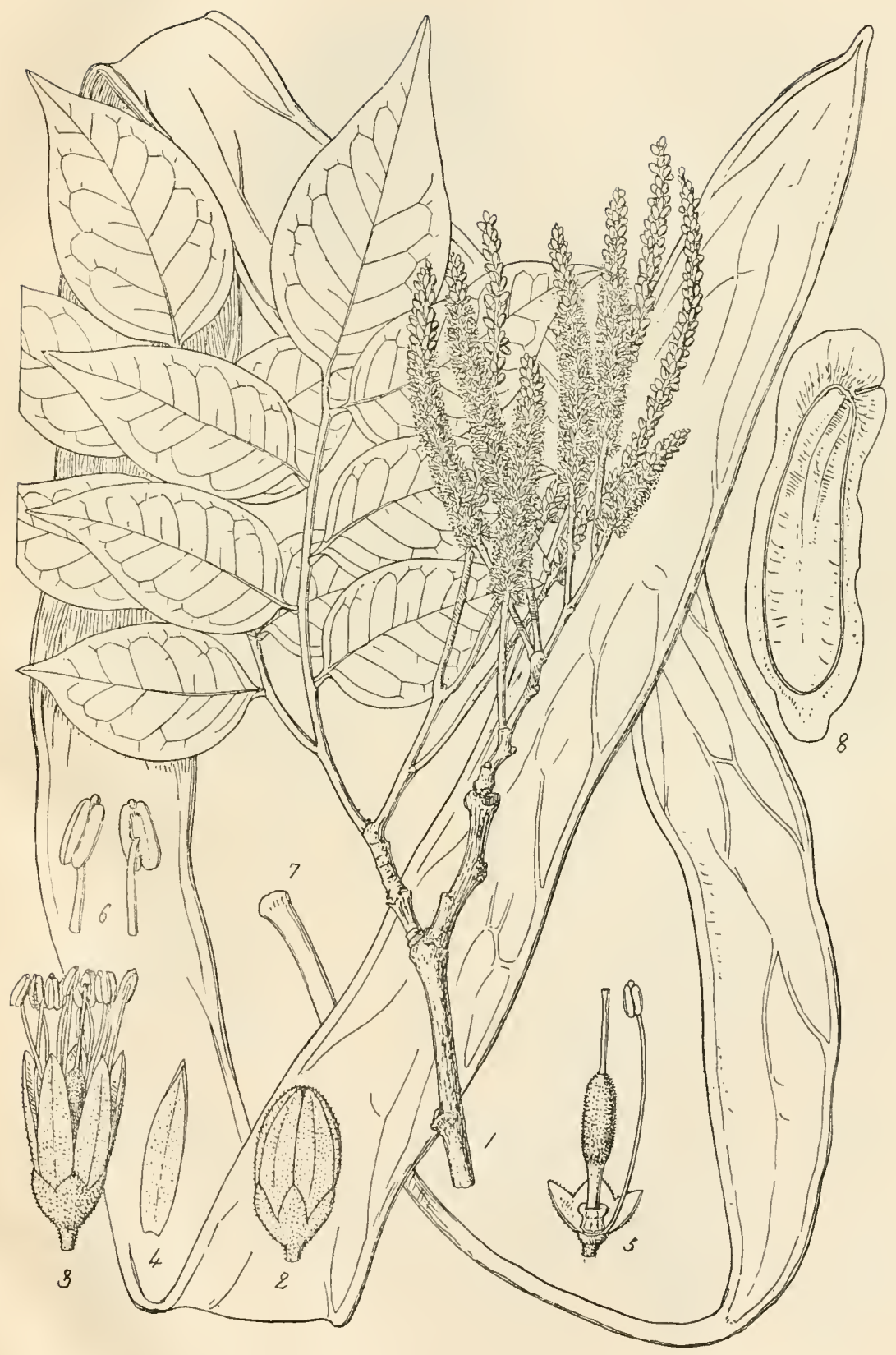


PL. 18.

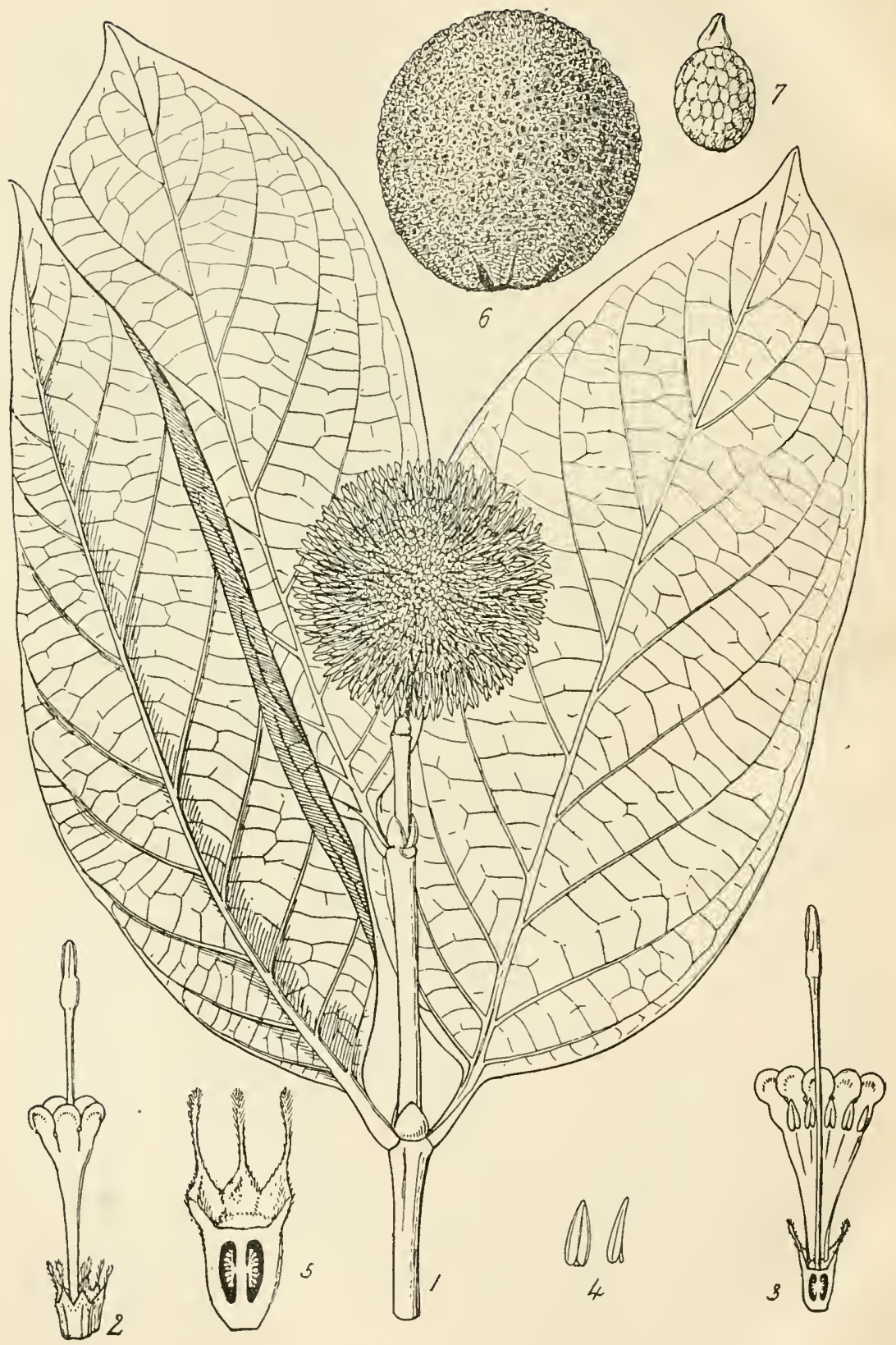


PL. 19.

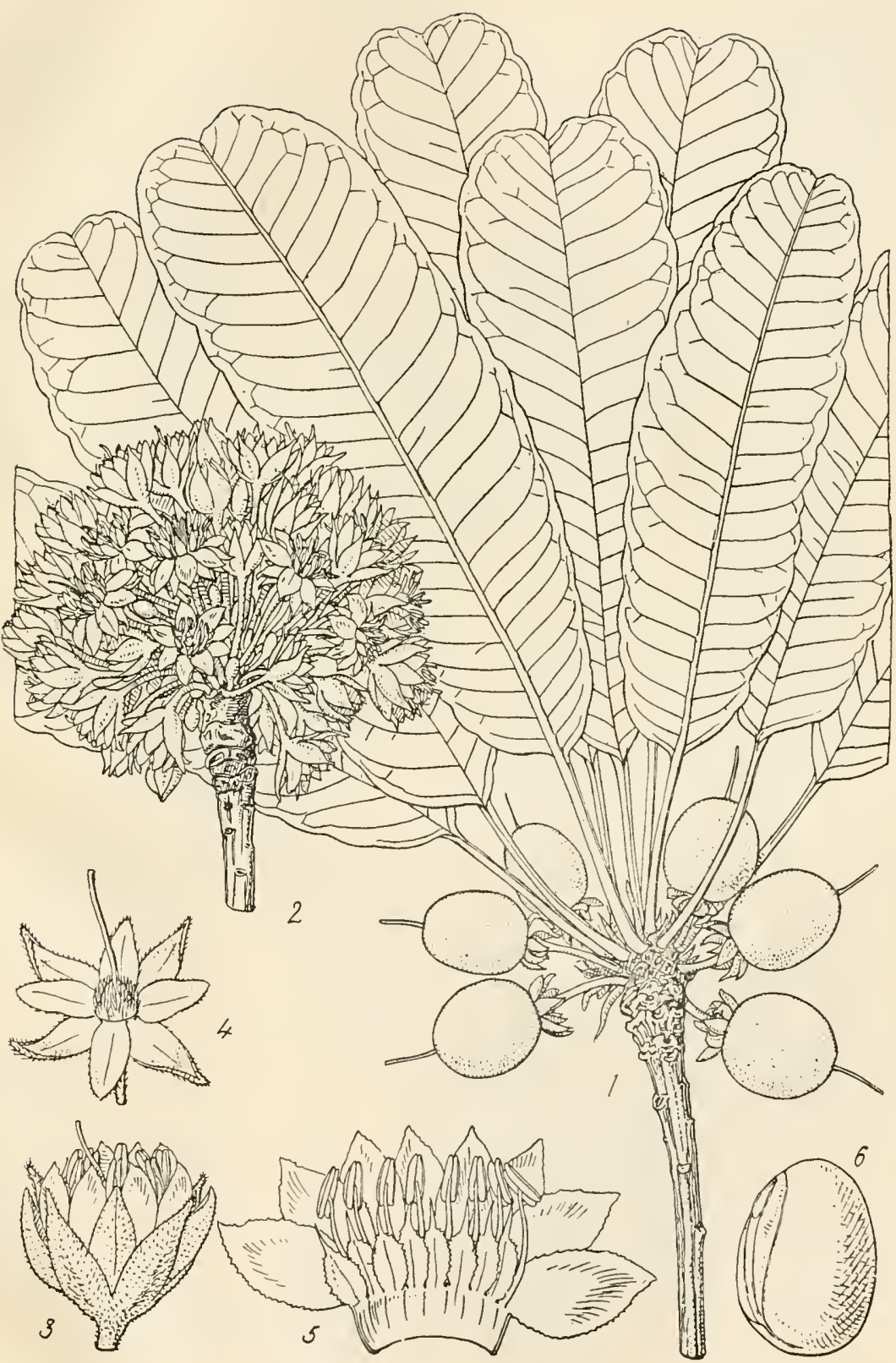


PL. 20.

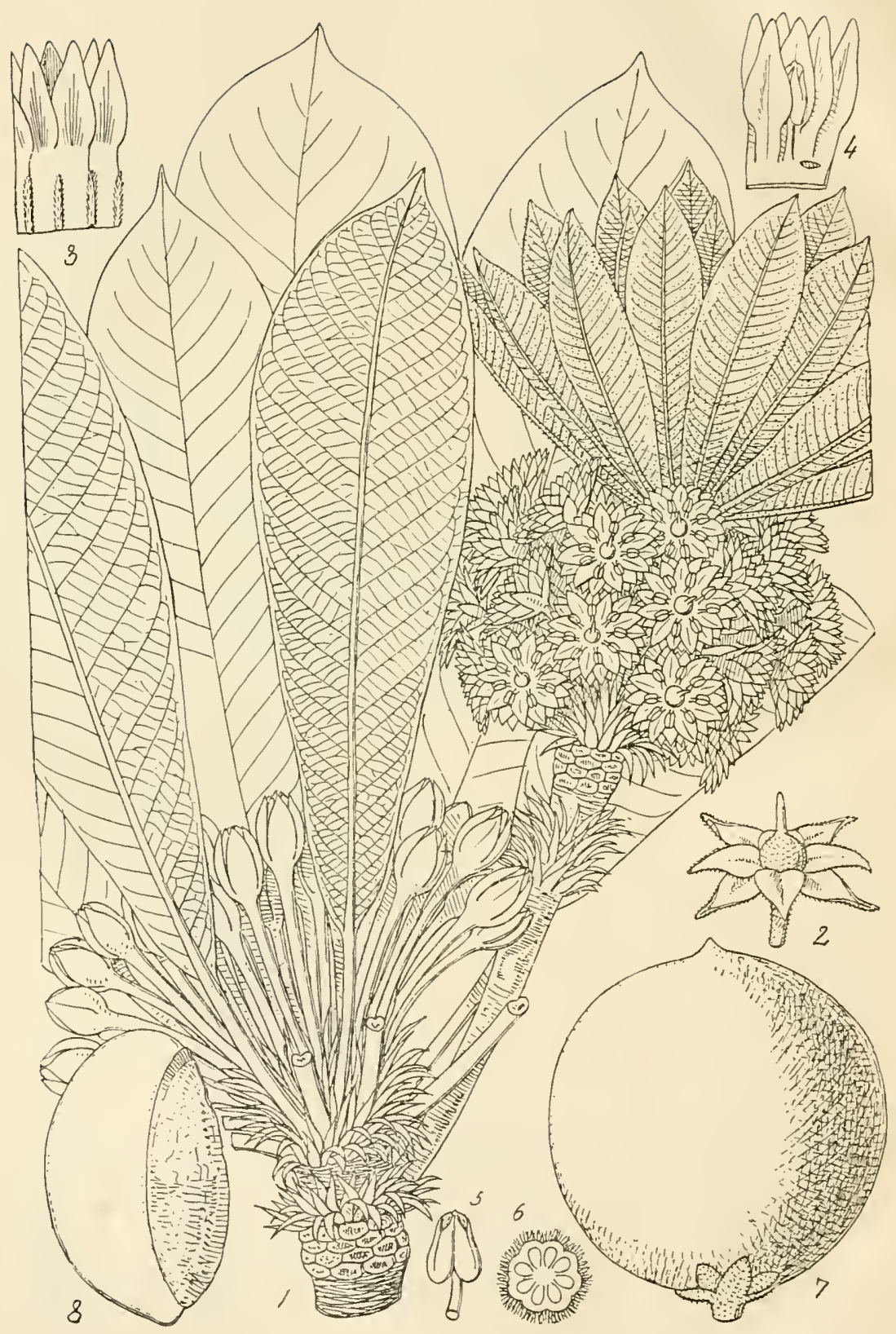

Mimusops DJave. 
PL. 21.

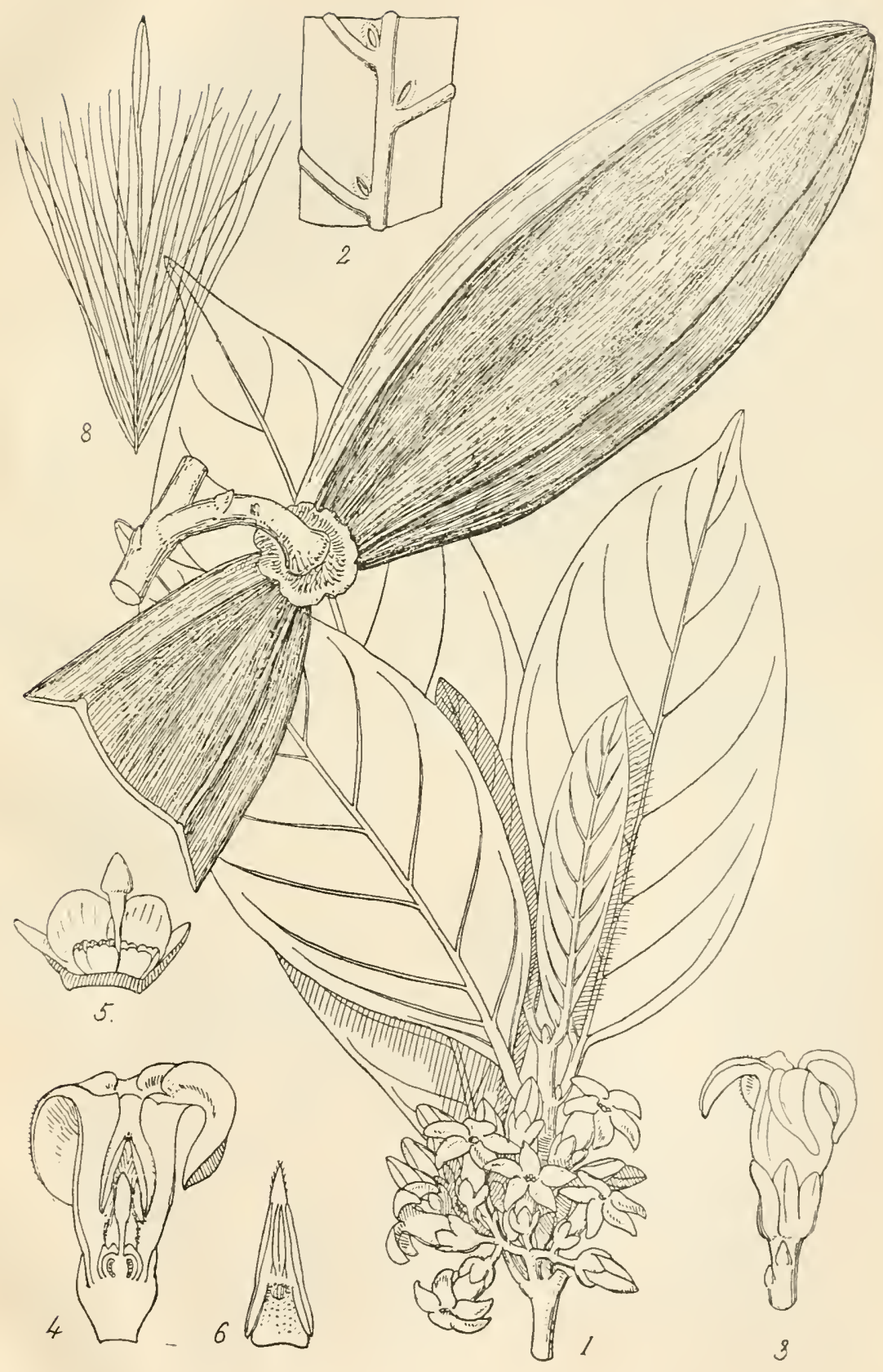

Funtomia elastica. 
PL. 22.

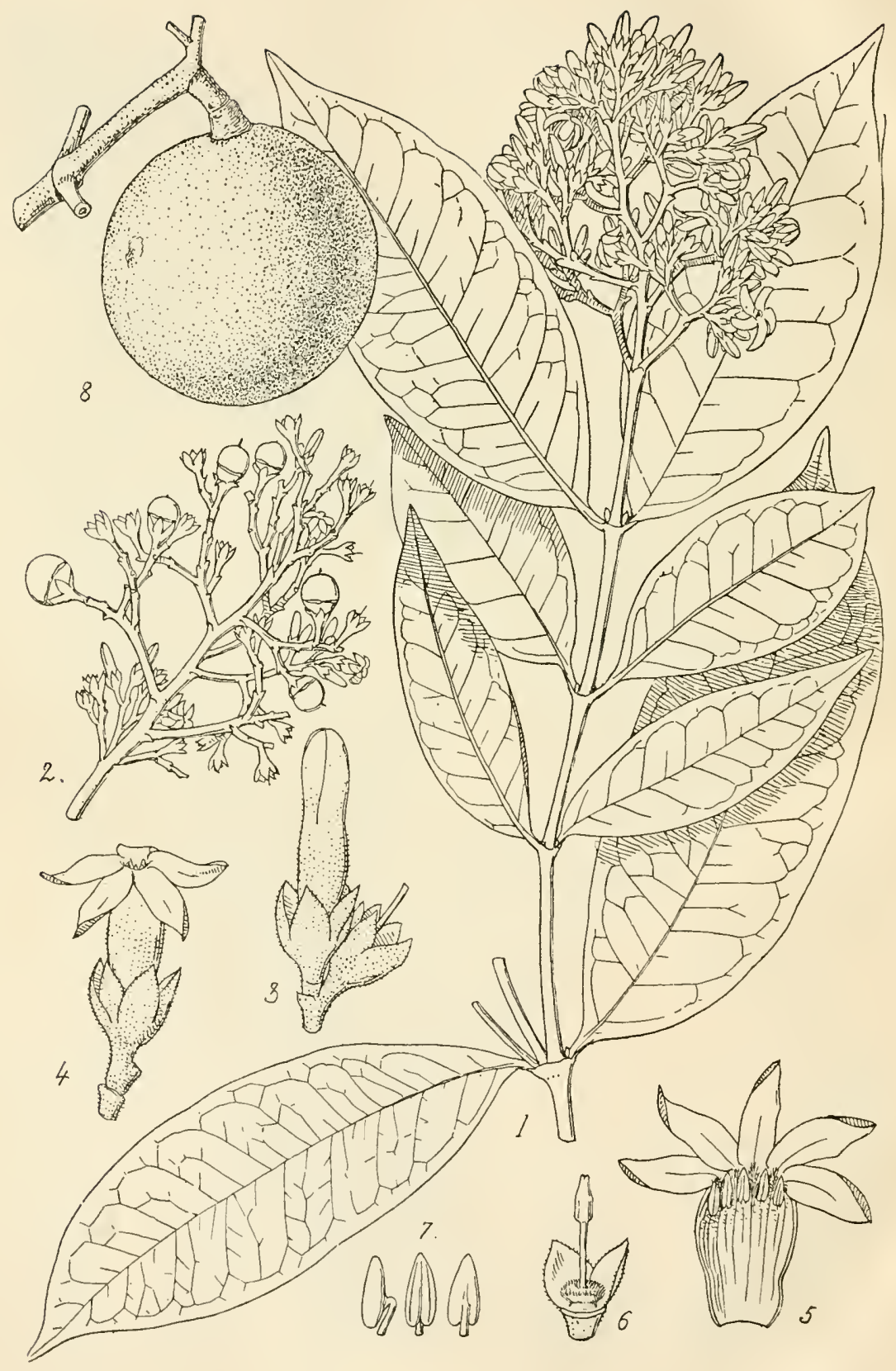


PL. 23.

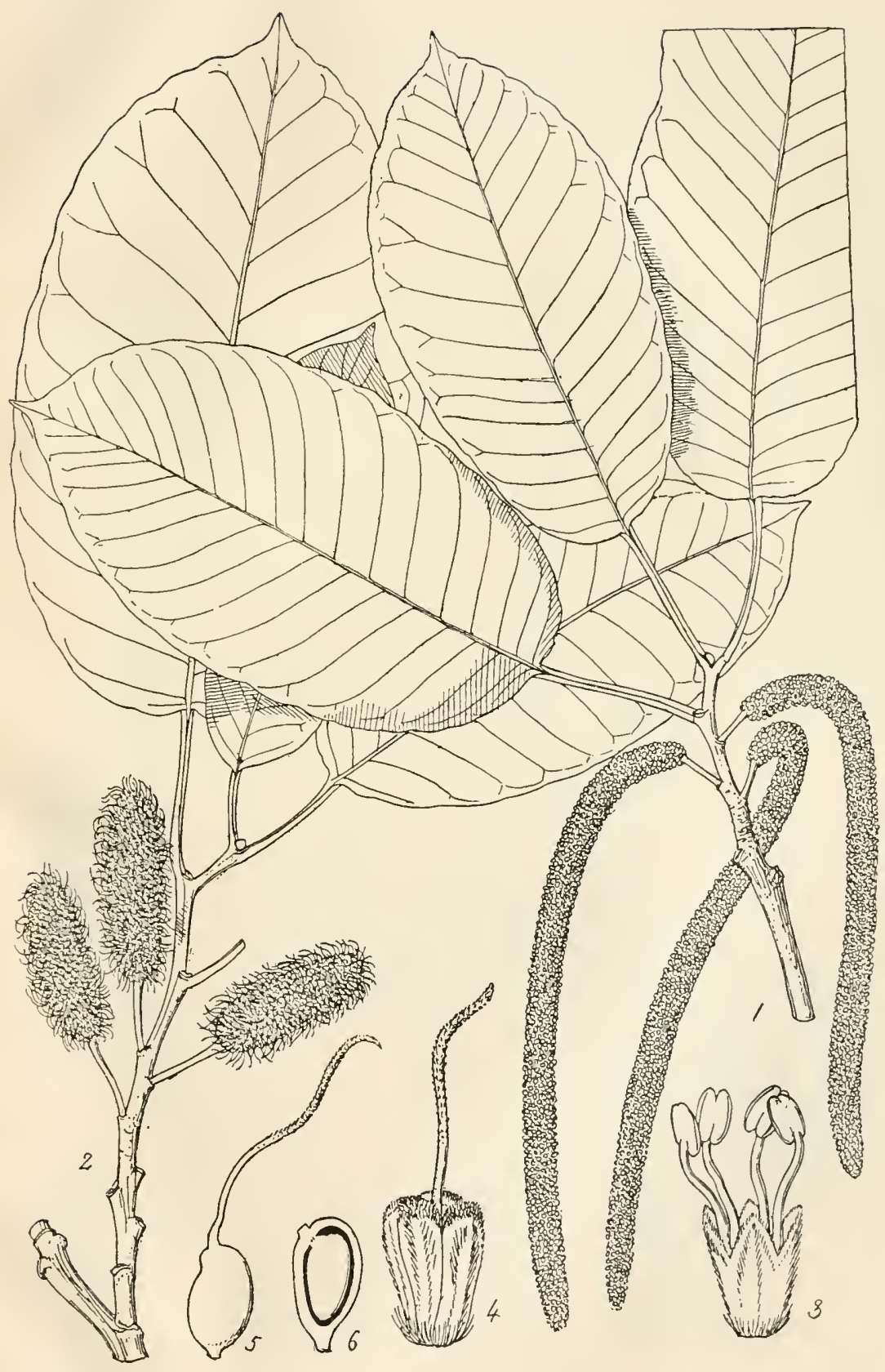

Chlorophora excelsa. 
PL. 24.

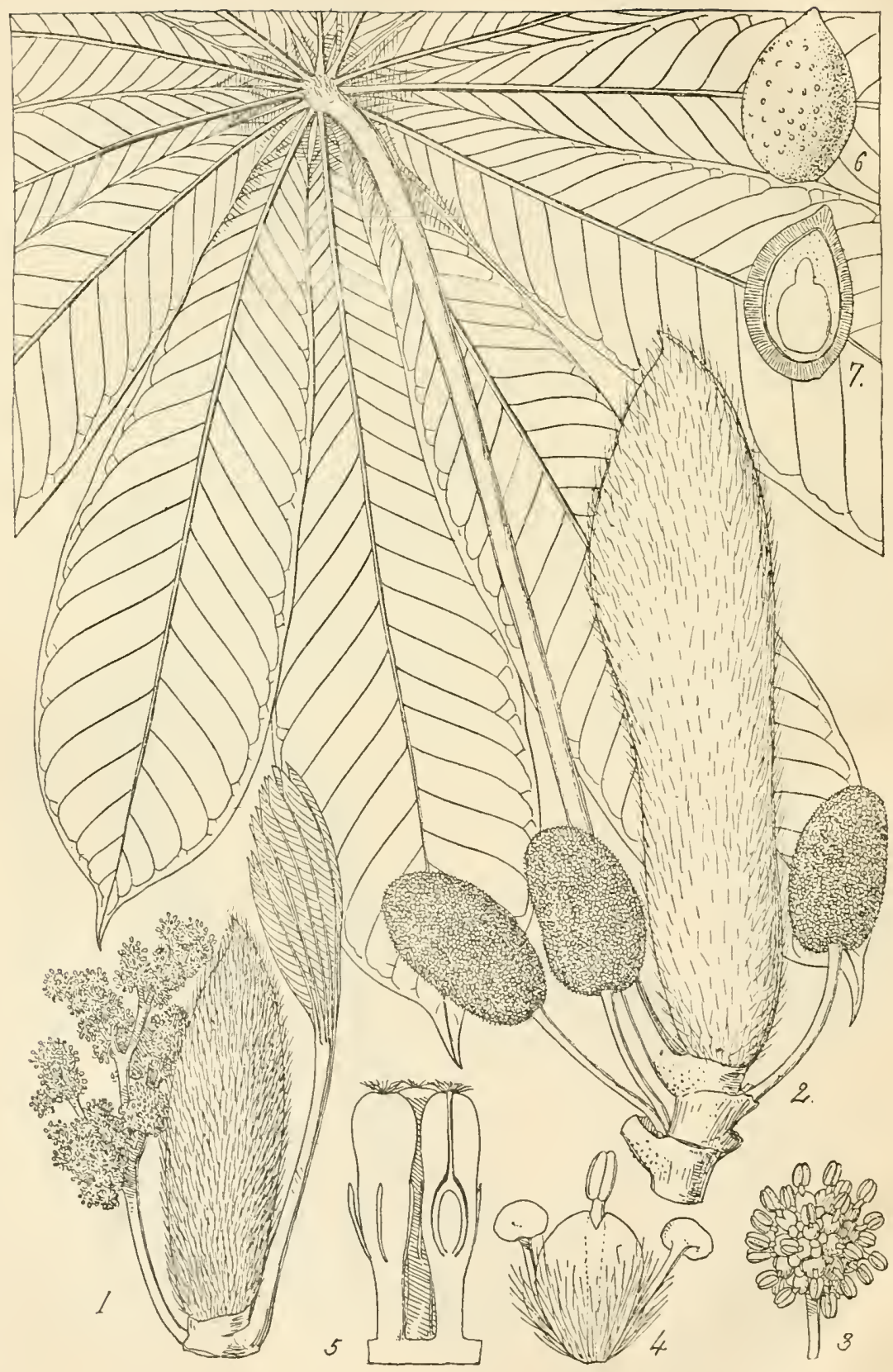




\section{N D E X.}

A.

A betifi

\section{Abetifi hills}

Abetinso

Abosso mines

Abotoasibi ...

Abousendua.

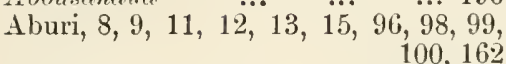

Aburi hills ...

$8,10,11$

Aburi hill forests ... $\quad \ldots \quad \quad \ldots \quad 10$

Acacia atexacuntha $\quad \ldots \quad 77,181$

A. Cateclue ... 8, 9, 66, 69, 73, 86, 91,

A. fastigiate

A. nigrescens.

187

A. pemate ... $\quad \ldots \quad \ldots 21,77,175$

A. Sieberiame, 9, 69, 86, 92, 187, 189

Acalypha ... $\quad \ldots \quad$... 21,175

Acanthacee $\quad$... $\quad \ldots . \quad \ldots 182$

Acanthus montana ... $\quad \ldots \quad \ldots 182$

Accra $\quad \ldots \quad \ldots \quad 7,10,15,162$

Accra-Aburi road ... $\quad \ldots \quad \ldots \quad 9$

Accra plains $\quad \ldots \quad \ldots \quad \ldots \quad \%, 9,97$

Acliyronthes $\quad \ldots \quad \ldots . \quad \ldots \quad 22$

Acridocarpus Smeathmanii $\ldots 180$

$\begin{array}{llllll}\text { A. sp. } \quad \ldots & \ldots & \ldots & \ldots & 51\end{array}$

$\begin{array}{llllll}\text { Adadawa } & \ldots & \ldots & \ldots & \ldots & 196\end{array}$

Adansonia ... $\quad \ldots \quad \ldots . \quad \ldots 8,9$

A. digitata, 70, 71, 73, 87, 91, 92, 168,

$186,187,189$

Adda lagoon $\quad \ldots \quad \ldots \quad \quad \ldots \quad 160$

$\begin{array}{llllll}\text { Adiemra } & \ldots & \ldots & \ldots & \ldots & \ldots\end{array}$

$\begin{array}{llllll}\text { Adjara } \quad \ldots & \ldots & \ldots & \ldots & 50\end{array}$

Adra river. 51, 52, 53, 55, 56, 59, 77,

Adubia $\quad . . . . .60,161$

$\begin{array}{lllll}\text { Adu-Kuma... } & \ldots & \ldots & \ldots & 57 \\ & \ldots & \ldots & \ldots & 58\end{array}$

Adwenyede village $\quad \ldots \quad \ldots \quad$... 47

$\begin{array}{llllll}\text { Aerua } & \ldots & \ldots & \ldots & \ldots & \end{array}$

Afunc $\quad \ldots \quad \ldots \quad \quad \ldots \quad 21,175,196$

Affram $\quad \ldots \quad \ldots \quad \ldots \quad 10,196$

Afram $\quad \ldots \quad \ldots \quad \ldots \quad 19,175$

Afram plain, $73,74,84,89,93,97,161$

Afram river, 90, 92, 94, 95, 160, 162

Aframsu $\quad \ldots \quad$... $\quad \ldots \quad$... 94

African oak $\quad \cdots \quad \cdots \quad{ }^{\prime} \quad \cdots 6,213,218$

Afrormosic laxiflore, $36,65,66,181$, $183,184,185,197$
PAGES

Afzelia africana (PI. 14), 9, 61, 62, 64, $66,69,73,74,86,88.94,122,138$, $139,175,181,184,187,189,198$ A. sp. $\quad \ldots \quad \quad \ldots \quad \ldots 38,50,51$ $\begin{array}{llllll}\text { Agave } & \ldots & \ldots & \ldots & \ldots & 8\end{array}$ Age Gradations $\quad \ldots \quad$... $\quad \ldots \quad 22$ $\begin{array}{lllll}\text { Ageratum } & \ldots & \ldots & \ldots & 22,70\end{array}$ $\begin{array}{lllll}\text { Agona } & \ldots & \ldots & \ldots & 46,47\end{array}$ thedue $\quad \ldots \quad \ldots \quad \ldots \quad \ldots \quad$... 196 $\begin{array}{llllll}\text { Ahframe } & \ldots & \ldots & \ldots & \ldots & 9\end{array}$ $\begin{array}{llllll}\text { Ahiraso } & \ldots & \ldots & \ldots & \ldots & 62\end{array}$ $\begin{array}{lllll}\text { Ahiraso-Ka... } & \ldots & \ldots & \ldots & 61\end{array}$ $\begin{array}{llllll}\text { Ahirisu } & \ldots & \ldots & \ldots & \ldots & 31\end{array}$ Ahirisu village $\quad \ldots \quad$... $\quad \ldots \quad 35$ $\begin{array}{lllll}\text { Altore } \quad \ldots & \ldots & \ldots & 213,218\end{array}$ Ahurum river $\quad \ldots \quad$... $\quad . .6162$ $\begin{array}{llllll}\text { Alata } & \ldots & \ldots & \ldots & \ldots & 196\end{array}$ $\begin{array}{llllll}\text { Akikere } & \ldots & \ldots & \ldots & \ldots & \end{array}$

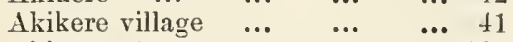
Akim, eastern $\quad \ldots \quad \ldots . \quad \ldots \quad 160$

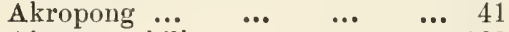
Akropong hills $\quad \ldots \quad \ldots . \quad \ldots \quad 162$ $\begin{array}{llllll}\text { Akusa } & \ldots & \ldots & \ldots & \ldots & 160\end{array}$ Akicabohori $\quad \ldots \quad$... $\quad \ldots 196$ Alwantanuro $\quad \ldots \quad \ldots \quad \ldots 196$ Akwapem hills $\quad \ldots . \quad \ldots . \quad \ldots 162$ $\begin{array}{llllll}\text { Akwasihu } & \ldots & \ldots & \ldots & \ldots & 83\end{array}$ $\begin{array}{llllll}\text { Akyam } & \ldots & \ldots & \ldots & \ldots & 85\end{array}$ Akyem $\quad \ldots \quad \ldots \quad \ldots 97,98,100$ Alafia Barteri $\quad \ldots \quad$... $\quad \ldots 182$ 1. landolphioides ... $\quad . . \quad \ldots 182$ Albizia $\quad \ldots \quad \ldots \quad 57,59,62,77$ A. angolensis $\quad \ldots \quad \ldots \quad \ldots 187$ A. Brownei, 37, 39, 41, $\dddot{3}, 58,634,66$, $72,181,184,190$ A. fastigiatu, 58, 72, 181, 184, 185, 190 A. rhombifolia $\quad$.. $\quad$... $\quad \ldots 175$

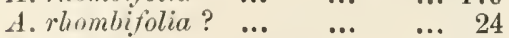

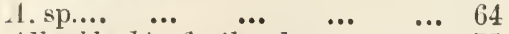
Allanblackia floribunda $\ldots . \quad \ldots \quad 175$ Aloe $\quad \ldots \quad$... $\quad \ldots . \quad \ldots .74$ A. Barteri ... $\quad \ldots \quad \ldots . \quad \ldots \quad 70,188$ Alstonia congensis, $10,20,34,37,44$, $47,56,59,67,83,87,175,178,197$ Amanchia ... $\quad . . \quad \ldots \quad 57,58$ Amuryllidece $\quad \ldots \quad 70,87,183,188$ Amaso river $\quad \ldots \quad$... $\quad \ldots 161$ Amomum $\quad \ldots \quad \ldots \quad \ldots \quad \ldots \quad \dddot{75}, 180$ A. Danielli $\quad \ldots \quad \ldots \quad \ldots 183$ 


\begin{tabular}{|c|c|c|c|}
\hline & & & PAGES \\
\hline A. Jatifolium & $\cdots$ & & ... 183 \\
\hline A. Melegueta & ... & .. & \# 183 \\
\hline Amorplinphallus & $\ldots$ & $\ldots$ & 21,183 \\
\hline Ampelinter & $\ldots$ & ... & ... 187 \\
\hline Anacarliacere & $\ldots$ & ... & ... 181 \\
\hline Anehi & $\ldots$ & $\ldots$ & ... 196 \\
\hline Anchomanes slubins & & $\cdots$ & ... 178 \\
\hline A. Hookeri & ... & .. & ... 183 \\
\hline A. sp. $\quad$. & $\cdots$ & . & ‥ 183 \\
\hline yllum. & & & \\
\hline Audropogon & $\cdots$ & & 70,189 \\
\hline Angraecum... & .. & $\ldots$ & 21,174 \\
\hline
\end{tabular}

Ankobra river, 24, 27, 31, 35, 37, 38, $39,46,47,48,52,160,161,191$

Ankobra river basin $\quad \ldots \quad \ldots 176$

Ankobra-Tano Water-Parting ... 41

Amgeissus beiocarpus, $70,73,87,91$, $92,187,189$

Anona palustris $\quad \ldots \quad \ldots \quad \ldots 178$

A. senegalensis, $9,16,70,87,92,186$ Anonacere ... $\quad . . \quad \ldots \quad 180,186$ Authocleistre mugnificu, ... 9, 10,197 A. mobilis $\ldots \quad \ldots \quad \ldots \quad 21,178$ A. sp. $\quad \ldots \quad \ldots \quad \ldots 6 \quad \ldots 67$ Antiaris toxicaria $10,39,81,174,175$ A. toxicaria var. africana, $10,20,35$, $36,41,45,57,67,84,198$

Antidesma renosum $\quad$... $\quad \ldots 188$ $\begin{array}{llllll}\text { A. } \mathrm{sp} . & \ldots & \ldots & \ldots & \ldots & 70\end{array}$ Anum forests $\quad \ldots \quad \ldots \quad \ldots 81$ Anum river $\quad \ldots \quad 80,160,162,191$

Anyinabirem village $\quad \ldots \quad \quad \ldots \quad 41$

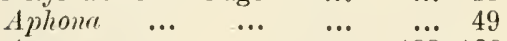

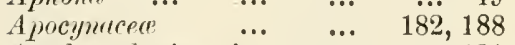
Apodytes beninensis $\quad$... $\quad$... 181 Appripriyi $\ldots \quad \ldots \quad \ldots \quad \ldots 196$ $\begin{array}{llll}\text { Apurro } \quad \ldots & \ldots & 21,175,196\end{array}$

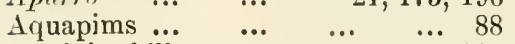
Aquipim hills $\quad \ldots \quad \ldots \quad \ldots 161$ Argemone mexiram $\quad \ldots \quad 70,186$ $\begin{array}{llllll}\text { Arridere } & \ldots & \ldots & \ldots & \ldots & 183\end{array}$ Aroids $\quad \ldots \quad \ldots \quad \ldots \quad 174,178$ Artobotrys Thomsomii $\quad$... $\quad$.. 174 Asankagwa... $\quad \ldots \quad \ldots \quad 42,191$ $\begin{array}{llllll}\text { Asare } & \ldots & \ldots & \ldots & \ldots & 67\end{array}$ Asare village $\quad \ldots \quad \ldots \quad \ldots 69$ Asclepiader $\quad \ldots \quad \ldots . \quad \ldots 0,182$ Ashanti stools $\quad \ldots \quad$... $\quad \ldots \quad 59$ Asiradue $\quad \ldots \quad \ldots \quad \ldots \quad 36,37,42$ Asome $\ldots \ldots, \ldots 196$ Asnmah, $19,20,23,26,37,48,84,175$ Asparrigus africremes $\quad . .70,87,188$ A.Prati-Guilelmi $\quad$.. $\quad \ldots 188$ Aspleninem $\ldots \quad \ldots \quad \ldots \quad \ldots \quad \ldots \quad 21$ Assawasè village $\quad \ldots \quad \ldots \quad \ldots \quad \ldots \quad 47$ Assolema tree $\quad \ldots \quad$... $\quad$... 9 $A \sin n \quad \ldots \quad \ldots \quad \ldots \quad 36,196$ Asuaso village $\quad \ldots \quad$... $\quad \ldots \quad 24$ A tabobo $\quad \ldots \quad \ldots \quad \ldots \quad \ldots \quad 90,93$ Atasi mines $\quad \ldots \quad \ldots \quad \ldots 48$ Athercale, 10, 20, 28, 36, 49, 122, 123, Atikwa bills Aricemia africana $\quad$... $\quad$... 190 Awabima $\quad \ldots \quad$... $\quad \ldots \quad \ldots 196$ A wrma, $20,23,27,36,37,122,123$, $146,175,176,177,183,184$

A were river

Axim $\quad$...

Axim district ... $\quad \ldots \quad \ldots 162$ $35,39,160,162,191$ B.

Ba river $\quad \ldots \quad \quad \ldots \quad \quad \ldots \quad 64,67$ Bulu, 10, 18, 22, 24, 26, 27, 28, 36, 38, $39,42,47,48,51,57,58,61,81$, $83,121,123,146,177,195,196$

Balsam copaiba tree, $9,69,86,88,92$,

122

Bamboo palm $\quad \ldots \quad \ldots \quad \ldots 190$

$\begin{array}{llllll}\text { Banana } & \ldots & \ldots & \ldots & \ldots & 93\end{array}$

Banda district $\quad \ldots \quad$... $\quad \ldots 162$

Banda hills $\quad \ldots \quad \ldots \quad 67,75$

$\begin{array}{lllll}\text { Bansu } & \ldots & \ldots & \ldots & 79,80\end{array}$

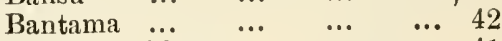

Bantama village $\ldots . \quad \ldots \quad \ldots \quad 41$

Bunbab, 9, 70, 71, 73, 87, 91, 168, 187 ,

189

Baphia mitidn $\quad \ldots \quad$... $\quad 87,89$

B. $\mathrm{sp}, \quad \ldots \quad \quad \ldots \quad \ldots \quad \ldots 175$

Bantimin reticulate, 9, $87,91,187,189$

Ваула, 10, 21, 26, 36, 43, 177, 178, 196

Begoniu sp... $\quad$... $\quad \ldots \quad$... 84

Begora range $\quad \ldots, \quad \ldots \quad \ldots, 99$

Berlinia ucominata, $21,72,87,89,175$,

B. anriculata $\quad$.. $\quad \ldots \quad \ldots 175$

Bertiera montana $\ldots . \quad \ldots . \quad \ldots \quad \ldots 175$

$\begin{array}{lllll}\text { Bery } \quad \ldots & \ldots & \ldots & 74,75\end{array}$

Bia ... $\quad \ldots \quad \ldots \quad \ldots, \quad \ldots \quad 51$

Bia river $\quad \ldots \quad \dddot{62}, 64,66,161,191$

Bia River Drainage $\quad . .6 \quad \ldots 63$

$\begin{array}{llll}\text { Bian } \quad \ldots & \ldots & \ldots & 74,93\end{array}$

Bibiani, $\quad \cdots 51,57,58,60,61,63,160$

Bidlens $\quad \ldots \quad \ldots \quad \ldots \quad 21,70$

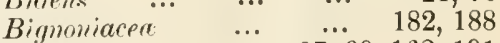

Birrim river, $\quad \cdots 11,97,99,162,191$

"Bitters" ... ... ... ... 40

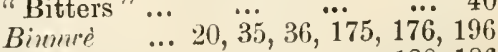

Bixinew $\quad \ldots \quad \ldots \quad \ldots \quad 180,186$

Black Volta river ... $\quad \ldots \quad 160,161$

Blighire sapide $\quad . . \quad$... $\quad 70,198$

Boprharia recendens $\quad \ldots . \quad \ldots 70$

$\begin{array}{lllll}\text { B. panicrelate } & \ldots & \ldots & \ldots & 70\end{array}$

Bogora range $\quad \ldots \quad \ldots \quad 162,191$

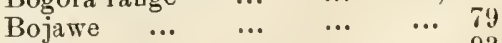

$\begin{array}{llllll}\text { Bola } & \ldots & \ldots & \ldots & \ldots & 93\end{array}$

$\begin{array}{llllrr}\text { Bole } & \ldots & \ldots & \ldots & \ldots & 74 \\ \text { Bombacer } & \ldots & \ldots & \ldots & 180,187\end{array}$

Bomlax brevicuspe (Pl. 1), 40, 50, 174,

$175,177,197$ 
PIGES

B. Lumeopozense, $9,10,20,38,39,196$.

B. malubaricum $\ldots \quad \ldots \quad \ldots \quad \ldots \quad 40$

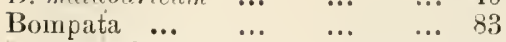

Bompata hills $\quad \ldots \quad \ldots \quad \ldots \quad 162,191$

Bonsa river $\quad \ldots . \quad \ldots . \quad \ldots \quad 25$

Boressus flubelliformis $\quad \stackrel{8}{8}, 16,70,92$, 189,197

B. flabelliformis var. rethiopiea, 9, 62, $74,87,90,188$

Bol'assus Palm ... ... ... 62 Bosse, 17, 35, 36, 41, 42, 48, 121, 123 , $175,176,196$

Bosumptwi Lake ...

Bosuellice ... ...

B. Klaineame $\quad \ldots \quad \ldots . \quad \ldots \quad 36$

Botanical Goule $\cdots \quad$... 37,177

Botanical Survey $\quad \cdots \quad$... 12

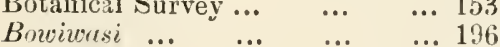

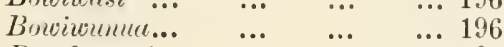

Brachystegiu $\quad \ldots \quad$... $\quad \ldots \quad 93$

B. sp. $\quad \ldots \quad \quad \ldots \quad \quad 27,2>, 48,55$

Braha $\quad \ldots \quad \ldots \quad 65,68,73,93$

Braha-Oboase range $\quad . . \quad \ldots .73$

Bridelia micrenthe, 70, 87, 91, 188, 189

Bricleliu sp. $\quad \ldots \quad \quad \ldots \quad \ldots 7,8$

Brimang $\quad \ldots \quad \ldots \quad \ldots \quad \ldots \quad 44,46,47$

$\begin{array}{llllll}\text { Bromase } & \ldots & \ldots & \ldots & 41 & \\ & \ldots & \ldots & 31\end{array}$

Bromase mines $\quad \ldots \quad \ldots \quad \ldots \quad \ldots \quad 32$

Bulbostylis barbute $\quad$... $\quad 70,188$

B. luniceps... $\quad \ldots \quad \ldots \quad 70,188$

Bunda river $\quad \ldots \quad \ldots \quad$... $85,87,94$

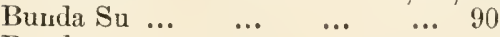

Bundasu $\quad \ldots . \quad \ldots . \quad \ldots . \quad \ldots .94$

$\begin{array}{llll}\text { Bunsu } & \ldots & \ldots & \ldots\end{array}$

Buttresses ... … ... ... 174

Butyrospermum I'rekii (PI. 19), 9, 70, $73,87,9 €, 122,138,188,189,197$

\section{c.}

Cabbage weed $\quad \ldots \quad$... $\quad \ldots 178$ Cresalpinia Bonducella ... ... 175 Calamus $\quad \ldots . \quad \ldots 21,46,56,59,174$

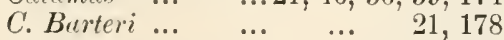
C'. sp. $\quad \ldots \quad \ldots \quad \ldots 62,67,183$ Cullichiliu Burteri $\quad \ldots \quad \ldots 182$

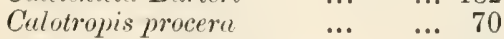
Camwood tree $\quad \ldots \quad \ldots . \quad \ldots \quad 87,89$ Cunurium Schweinfurthii... ... 175 Cape Coast... $\quad$... $\quad \ldots . \quad \ldots \quad 162$ Capparidecer $\quad \ldots . \quad \ldots . \quad \ldots 186$ $\begin{array}{llllll}\text { Capperis } & \ldots & \ldots & \ldots & \ldots & 87\end{array}$ C. sp. $\quad \ldots \quad \ldots . \quad \ldots 7,8,9,186$ C'urupa $\quad \ldots \quad \ldots \quad \ldots \quad 122,123$ C. guimensis, $\quad \dddot{62}, 72, \ddot{7} 3,87,89,91$, $177,181,184,190,198$

Corvissure edulix 87,188 Cupodimus.... $\quad \ldots \quad 45,77,174,177$
PAGES

C. Burteri ... $\quad \ldots \quad$... $\quad \ldots 18 \%$

C. fiulve $\quad \ldots \quad \ldots \quad \ldots \quad \ldots \quad \ldots 182$ C. hirsute ... 21, 36, 38, 44, 56, 64, 73, $87,177,182,184,190$

Crrepuloblice lutere $\ldots \quad$... $\quad . .175$

Cassava farms $\quad \ldots . \quad \ldots . \quad \ldots \quad 10$

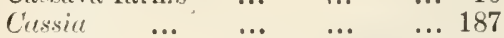

C. fistule, $\quad \ldots \quad \quad \ldots \quad \quad 72,181,185$

C. mimusuides $\quad \ldots \quad \ldots \quad \ldots \quad \ldots 87$

Castillon elasticu $\ldots . \quad \ldots \quad \ldots \quad 12,13$

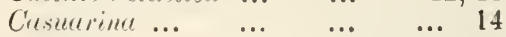

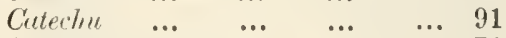

Cauliflory ... $\quad . . \quad$... $\quad \ldots 174$

$\begin{array}{llll}\text { Ceara rubber-trees } & \ldots & \ldots & 12\end{array}$

Cedar ... 18, 37, 48, 51, $56,62,69,75$, $77,79,81,83,86,88,121,122,123$. $126,145,176,184,213$

Cedar forests $\quad \ldots \quad \quad \ldots \quad \quad \ldots \quad 51$

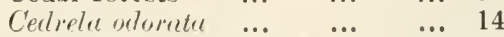

Celestrurer $\quad \ldots \quad \ldots \quad \ldots 183$

Cercestis $\quad \ldots \quad$... $\quad \ldots \quad 21,174$

Chasmophytes $\quad . . \quad \ldots \quad \ldots \quad \ldots 74$

Chen-rlen ... $\quad \ldots \quad 10,35,36,57,84$

Chew-stick tree $\quad \ldots \quad 70,86,87,92$

Chichawere $\quad \ldots \quad \ldots, 162,191$

Chloropleore exeelse (PI. 23). 10, 18, $20,23,32,36,37,41,42,51,56$, $58,60,61,66,72,75,77,78,84$, $121,123,124,146,175,176,18:$, $184,186,190,195,198,213,218$

Christiausbor'g Castle ... ... 7

Chrysophyllume albidum ... ... 182

$\begin{array}{llll}\text { Cleome iliutu } & \ldots & \ldots & 70,186\end{array}$

r'lervdendron splendens $\quad \ldots \quad$... 182

C. rioluceum $\quad \ldots \quad$... $\quad \ldots .175$

Climate $\quad \ldots \quad \quad \ldots \quad \ldots \quad 159,162$

C'liturelre $\quad \ldots \quad 10,38,45,77,174,177$

C. elastice ... $\quad$... $\quad$... $\quad \ldots .213$

C. toyolene $\quad \ldots . \quad \ldots . \quad \ldots 182$

Cinestis ferrugined ... $\quad$... $\quad . .181$

Cochlospermum timetorium 70, 87, 186

Cocoa $\quad \ldots \quad 76,78,79,82,93,97$

Cocoa farms $\quad$... ...

Coli $\quad \ldots \quad \ldots .78,79,82,97$

Colu Afselii $10,57,66,72,185,190$

C. cauliflora $\quad$... $\quad \ldots \quad \ldots 174$

C. cordifolie $\quad \ldots \quad \ldots 70,74,187$

C'. lemrifolie $\quad \ldots . \quad \ldots . \quad \ldots 180$

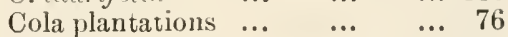

Collectors, hints to $\quad \ldots . \quad \ldots 153$

Combretucere $\quad$... 45, 70.181, 187

Combretum... ... 8, 10, 21, 77, 174

C'. comosum... $\quad$... $\quad \ldots . \quad \ldots 175$

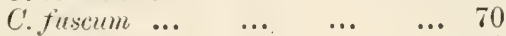

C. mueronutum $\quad \ldots \quad$... $\quad \ldots .70$

C. racemosum $\quad \ldots \quad \ldots . \quad \ldots \quad 70,181$

C. Zenlieri ... $\quad$... $\quad \ldots \quad$... 181

C. sp. $\quad \ldots \quad 20,37,81,175,197$

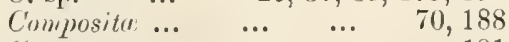

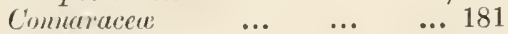

Conversions $\quad \ldots . \quad \ldots . \quad \ldots 190$

Corchorus ... $\quad \ldots . \quad \ldots . \quad \ldots \quad 70$

Condia Irvingii $\quad \ldots \quad \ldots \quad \ldots \quad 84,177$

$\begin{array}{llllll}\text { Corn } & \ldots & \ldots & \ldots & & \\ & & & \end{array}$ 


\begin{tabular}{|c|c|c|c|}
\hline \\
\hline Costus & & ... & 75,18 \\
\hline C. afer & & & \\
\hline \multicolumn{4}{|c|}{ Cremaspora africana } \\
\hline Crinum & $\ldots$ & \multicolumn{2}{|c|}{$87,178,183$} \\
\hline C. giganteum & $\cdots$ & & \\
\hline C. natans ... & ... & & 27 , \\
\hline C. purpurascen & ... & & \\
\hline \multicolumn{4}{|c|}{ Crussopteryx: Kotschyana ... 70, 87, 1} \\
\hline \multicolumn{4}{|c|}{ Crotalurice ... $\quad \ldots \quad \ldots 21,70,187$} \\
\hline Culcasia & .. & & 21,17 \\
\hline apple & & & \\
\hline e... & & & 86 , \\
\hline Cycenothyrsus & & 122 & 123,1 \\
\hline \multirow{2}{*}{\multicolumn{4}{|c|}{$\begin{array}{l}\text { C. ogea (Pl. } 15) \text {.. 27, 36, 37, 41, 42, } \\
\quad 45,55,56,57,61,77,81,84,196,\end{array}$}} \\
\hline & & & \\
\hline ... & $\ldots$ & & 10, \\
\hline$\ldots$ & & & \\
\hline & & $17 !$ & \\
\hline C. Mamii ... & 72 , & 178 & 181 , \\
\hline$\cdots$ & ... & $\ldots$ & \\
\hline Cyp & & & \\
\hline Cyrt & & & \\
\hline
\end{tabular}

\section{D.}

Dadiase $\quad \ldots \quad$... $\quad \ldots \quad$... 79

Dakomah, $\dddot{9}, 18, \ddot{19}, 20, \dddot{2} 2,23, \ddot{25}, 26$, $28,32,37,41,47,48,50,55,56,58$, $75,77,84,154,155,176,177,183$,

$\begin{array}{llllll}\text { Dahumah } & \ldots & \ldots & \ldots & \ldots & 197\end{array}$

Dalbergia latifolia $\quad \ldots \quad \ldots \quad 15$

$\begin{array}{llllll}\text { D. Sisso" } & \ldots & \ldots & \ldots & \ldots & 15\end{array}$

D. sp. $\quad \ldots \quad \ldots . \quad \ldots \quad 696,86$

Daleb palm... $\quad \ldots . \quad \ldots \quad \ldots \quad 16$

Dampia range $\quad \ldots 76,77,78,79,162$

Dampia Reserve ... ... ... 78

Daniella thurifera, 9, 69, 73, 86, 88, 92 .

Date palm 122, 187,189

Dendroeulamus He... Hiltomii $\quad 70,74,87$

D. sp. ? $\quad \ldots \quad \ldots \quad \ldots \quad 40,42,48$

Deinbollie insignis $\quad \ldots . \quad \ldots 181$

$\begin{array}{llllll}\text { Deinya } \quad \ldots & \ldots & \ldots & \ldots & 197\end{array}$

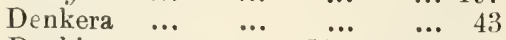

Denkira $\quad \ldots \quad \ldots \quad 51,76,160,191$

Densu river $\quad \ldots \quad 11,99,161,162$

Denya $\quad \ldots \quad \ldots . \quad \ldots \quad \ldots c 197$

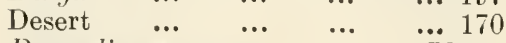

Desmodium... $\quad \ldots \quad \ldots \quad \ldots, \quad 70,87$

Detarium senegulense $73,86,88,94$, 187,189

D. sp. $\quad \ldots \quad 20,35,36,175,176,196$ Dialium grineense, $16,87,92,181,185$ 1). sp. $\quad \ldots \quad$... $\quad \ldots \quad \ldots r$ $\begin{array}{llllll}\text { Dianfutu } & \ldots & \ldots & \ldots & \ldots & 50\end{array}$ Dichrostuchys mutans $\quad \ldots 66,70,187$ Dido tree $\ldots . \quad \ldots \quad \ldots \quad$...
PAGES

Dikia nut $\ldots \quad \ldots \quad \ldots \quad \ldots \quad \ldots 219$

$\begin{array}{lllll}\text { Dioscorea alata } & \ldots & \ldots & \ldots & 183\end{array}$

D. prehensilis $\quad \ldots \quad \ldots . \quad \ldots 183$

D. Preussii $\quad \ldots . \quad \ldots . \quad \ldots 183$

Dioseoreacer $\quad \ldots . \quad \ldots \quad \ldots 183$

Diospyros mespiliformis, 72, 87, 89, 183

184,190

D. monbuttensis $\quad \ldots \quad \ldots \quad \ldots 183$

$\begin{array}{llllll}\text { D. sp. } & \ldots & \ldots & \ldots & \ldots & 175\end{array}$

Dipterocarpere $\quad \ldots \quad \ldots \quad \ldots \quad \ldots 188$

Dissotis prostrata ... $\quad \ldots . \quad \ldots \quad 70$

Distemonanthus Benthamianuss ... 175

$\begin{array}{llllll}\text { Domiabra } & \ldots & \ldots & \ldots & \ldots & 47\end{array}$

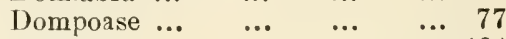

Doum Palm $\quad \ldots . \quad \ldots . \quad \ldots 188$

Draccence maculate $\quad \ldots . \quad \ldots 183$

Drainage systems ... $\quad \ldots \quad \ldots 160$

$\begin{array}{llllll}\text { Duabayi } & \ldots & \ldots & \ldots & \ldots & 36\end{array}$

Duakobin, $\dddot{36}, 64, \ddot{65}, 66, \dddot{1} 83,18 \ddot{8}, 197$

Ducumenyi $\ldots \quad \ldots \quad \ldots \quad \ldots 197$

$\begin{array}{llllll}\text { Dubima } & \ldots & \ldots & \ldots & \ldots & 40\end{array}$

$\begin{array}{llllll}\text { Dubin } & \ldots & \ldots & \ldots & \ldots & \ldots\end{array}$

Dubini, $10,20,27,28,32,36,40,42$, $45,47,49,51,55,64,121,123,176$,

184

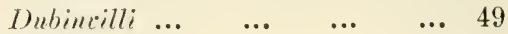

Dumanase village ... $\quad \ldots \quad \ldots, \quad 34$

Dunkwa $\quad \ldots \quad \ldots 43,46,48,49,51$

Dunkwa station ... ... ... 20

$\begin{array}{lllll}\text { Dye-plants ... } & \ldots & \ldots & \ldots & \ldots \\ & \ldots & & \ldots & 177\end{array}$

$\begin{array}{lllll}\text { Dyes } \quad \ldots & \ldots & \ldots & 185,189\end{array}$

\section{$\mathbf{E}$}

Ebenucer $\quad \ldots \quad \ldots \quad \ldots 6 \quad \ldots 183$

Ebony $\quad \ldots .72, \dddot{87}, 89, \dddot{121}, 1 \ddot{84}, 213$

Ebuta Mettı Gardens $\quad \ldots \quad 12,14$

$\begin{array}{llllll}\text { Edubir } & \ldots & \ldots & \ldots & \ldots & 59\end{array}$

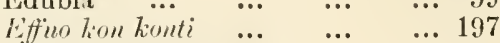

Effuokonkonti $\quad \ldots \quad \ldots . \quad \ldots \quad 60,184$

Efuobrodidwa $\quad \ldots \quad \ldots \quad \ldots 197$

$\begin{array}{lllll}\text { Lihye } & \ldots & \ldots & \ldots & \cdots\end{array}$

$\begin{array}{lllll}\text { Ehigeduce } & \ldots & \ldots & \ldots & 36,177 \\ & \ldots & \ldots & \ldots & 10,197\end{array}$

$\begin{array}{lllll}\text { liku... } & \ldots & \ldots & \ldots & 9,38,197\end{array}$

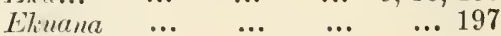

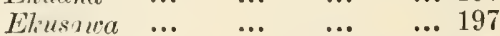

Elaeis guineensis, $\quad 175,177,183.184$

Emil $\quad \ldots \quad \ldots \quad \quad \ldots \quad 10,197$

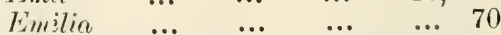

Emerit, $10, \dddot{20}, 28, \ddot{36}, 37,38,39,43,44$, $47,57,58,66,77,80,146,175,176$, $177,181,183,184,197$

Enema Krom Concession ... 23

$\begin{array}{lllll}\text { Engantan ... } & \text {... } & \text {... } & \ldots & 49\end{array}$ Entade ubyssinire... $\quad \ldots 69,87,187$ E. scandens $\quad \ldots \quad \ldots . \quad \ldots 174$ F. soudarica, $\quad \ddot{9}, 66, \ddot{69}, 73, \ddot{87}, 187$ Eintandropheragma ... $\quad \ldots \quad 213,218$ $\begin{array}{lllll}\text { Epiphytes ... } & \ldots & \ldots & \ldots & 174\end{array}$ 
$\begin{array}{llll} & & & \text { PAGES } \\ \text { Epum village } & \ldots & \ldots & \ldots 160\end{array}$

Eragrostis ... $\quad \ldots \quad$... $\quad 70,18$ ?

Exiodendron rufractuosum, 10, 19, 20, $24,37,56,62,66,70,72,73,80$, $81,82,84,87,174,175,176,180$, $186,187,190,198$

Erythrina senegalensis $\quad \ldots \quad 69,187$

E. tomentosa $\quad \ldots \quad \ldots 41,181,185$

Erythrophloem , mineense, 68, 69, 73, $86,87,89,122,187, \mathbf{3} 89,198$

Esea $\quad \ldots \quad \ldots \quad \quad \ldots \quad 81,83$

Esseah $\quad$.. $\quad \ldots \quad$... $\quad \ldots 197$

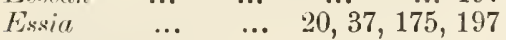

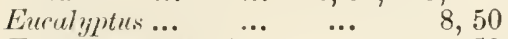

Eucalyptus citriorlora $\quad \ldots \quad$... 50

E. macrorhyncha $\quad \ldots \quad$... $\quad \ldots \quad 50$

E. marginatu $\quad \ldots \quad$... $\quad$... 50

$\begin{array}{lllll}\text { E. resinifer } & \ldots & \ldots & \ldots & 50\end{array}$

Eugeniu moariensis $\quad \ldots 70,87,187$

Enphurbia ... $\quad \ldots \quad \quad \ldots \quad \quad \ldots 8,74$

E. piluliferu $\quad \ldots \quad \quad \ldots \quad \quad \ldots \quad 70$

E. prostrata $\quad \ldots \quad \ldots . \quad \ldots \quad 70$

Euphorbiacece $\quad \ldots \quad \quad \ldots \quad 70,188$

Exeoecuria ... $\quad$... $\quad \ldots . \quad \ldots 188$

Exports of forest produce $\quad$... 192

Eye... $\quad \ldots \quad \ldots \quad \ldots \quad \ldots \quad \ldots 197$

$\mathbf{F}$

Fan palm ... 8, 70, 74, 87, 9ง, 94, 188

Fanti tribe

Fetish forest

Fibre plants

... $\quad \ldots \quad \quad \ldots \quad 19$

... $13, \ddot{177}, 18 \ddot{8}, 189$

Fibres $\quad \ldots \quad \ldots \quad \ldots . \quad \ldots 178$

Ficus, $\quad 10,12,39,45,7 \ddot{4}, 87,174,198$

F. asperifolire? ... $\quad \ldots \quad \ldots 188$

F. elastica $\ldots \quad \quad \ldots \quad \quad \ldots \quad 12,1$ ?

F. platyphylla $\quad \ldots \quad \quad \ldots . \quad 87,92$

$F$. Vogelii $\ldots \quad \ldots \quad$... 12, 182, 184

$F . \operatorname{sp} . \quad \ldots \quad \ldots 6 \quad 66,196,197$

Flabellavia эaniculatu $\quad$... $\quad$... 180

Flies $\quad \ldots . \quad \ldots \quad \ldots 6 \quad \ldots 66$

Flint wood tree $\quad \ldots 27,37,45,83,175$,

177, 198

Fomena $\quad \cdots \quad \ldots \quad \ldots \quad 77,78$

Formations, climatic $\quad . . \quad \ldots 170$

, edaphic $\quad \ldots . \quad \ldots 171$

Forest administration $\quad \ldots \quad$... 142

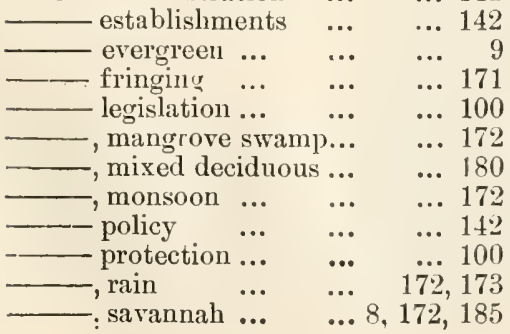

Forest, swamp $\quad 172,177$

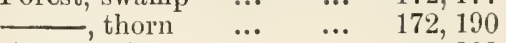

Forestry Ordinance $\quad$... ... 202

Frugivorous bats ... $\quad \ldots, \quad \ldots, 23$

Funtumia efricana, 10, 38, 45, 49, 182

198

F. elastica (Pl 21), 10, 12, 13, 15, 21, $37,41,43,44,47,49,50,51,57$, $58,61,62,64,66,77,78,79,82$, $83,84,87,122,123,146,175,177$, $182,183,184,213,219$

F. latifoliu... $\quad \ldots . \quad \ldots . \quad \ldots \quad 13$

$\begin{array}{lllll}\text { Fura Junction } & \ldots & \ldots & \ldots & \ldots \\ \end{array}$

\section{c.}

Gadean $\quad \ldots \quad$... $\quad$.. $\quad 213,218$

Gaiyin Krom Concession... ... 21

..___ saw-mills ... 16,17

Gambaga $\quad \ldots \quad \ldots \quad 161,102,164$

Garcinid $\quad . . \quad \ldots \quad \ldots \quad \ldots 174$

G. sp. $\quad \ldots \quad \ldots . \quad \ldots \quad \ldots \quad \ldots 26$

Gavdenia ternifolia? $\quad 70,87, \ddot{92}, 187$

Gloriosa superba ... $\quad \ldots \quad 10,87$

G. virescens $\quad \ldots \quad \ldots 70,87,188$

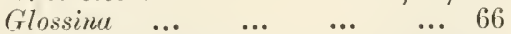

Glyphra grewioides $\quad \ldots \quad 72,180$

$\begin{array}{lllllll}\text { Grose } & \ldots & \ldots & \ldots & \ldots & 61\end{array}$

$\begin{array}{lllll}\text { village } & \ldots & \ldots & \ldots & 62\end{array}$

Grabossi $\ldots \quad$... $\quad \ldots . \quad \ldots \quad 49$

Grains of Paradise $\quad$... ... 180

Graminea ... ... ... 70, 71, 189

Grassland ... $\quad \ldots . \quad \ldots . \quad \ldots \quad 170$

Grevia carpinifolia $\quad \ldots . \quad \ldots 180$

Guarea, $17,35,36,41,121,123,175$,

$176,196,213,218$

Gum copal ...36, 41, 42, 56, 57, 61, 62, $77,81,84,122,123,146,175$

Gums $\quad \ldots \quad \quad \ldots \quad \quad \ldots \quad 92,189$

Grymandropsis pentaphylla $\quad 70,186$

X.

Hсемanthus... $\quad \ldots \quad 70,87,183,188$

Hienutoputa $\quad \ldots . \quad \ldots \quad \quad \ldots \quad 66$

Half Assini $\quad \ldots . \quad \ldots . \quad \ldots 160$

Harmattan wind ... $\quad \ldots \quad 163,164$

Haronga madayascarieusis, 10, 21, 77,

180

Harrisonia abyssinica $\quad$... $\quad$... 181

Heclieldora... $\quad \ldots . \quad \ldots \quad \ldots \quad$... 175

$\begin{array}{lllll}\text { Helichrysum } & \ldots & \ldots & \ldots & 22\end{array}$ 
PAGES

Heritiera utilis (PI. 3), 10, 17, 26, 32, $36,43,49,50,146,174,175,176$,

Heterupterys africune $\quad \ldots \quad \ldots 180$

IIccen brasilicusis ... $\quad \ldots \quad 13,31$

Heculobus yrandifolia $\quad \ldots \quad \ldots 180$

Ilibiscus, 70, 91, 177, 180, 185, 186, 189

II. lumerifolius $\quad \ldots \quad \ldots \quad \ldots 186$

Ilippocraten $\quad \ldots \quad \ldots . \quad \ldots \quad 77,174$

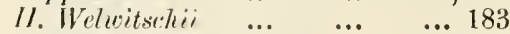

Hotarhene Wulfsburgii ... ... 182

Honclenya fucifolia $\quad 178,179,187$

Honum $\quad \ldots \quad \ldots \quad \ldots \quad \quad 9,197$

Hun village $\quad \ldots \quad \ldots . \quad \ldots \quad 55$

Huni river $\quad \ldots \quad \ldots . \quad \ldots \quad 25,27$

$\begin{array}{llllll}\text { Hunisu } & \ldots & \ldots & \ldots & \ldots & 27\end{array}$

$\begin{array}{lllll}- \text { village } \quad \ldots & \ldots & \ldots & 25\end{array}$

$\begin{array}{lllll}\text { Hydathodes } & \ldots & \ldots & \ldots & 167\end{array}$

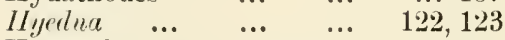

$\begin{array}{lllll}\text { Hygrophytes } & \ldots & \ldots & \ldots & 167\end{array}$

Hymenocullis senegambice 70,188

IIymenocardia $\quad \ldots \quad \ldots \quad \ldots \quad \ldots 188$

$\begin{array}{llllll}\text { H. sp. } \quad \ldots & \ldots & \ldots & \ldots & \ldots & 70\end{array}$

Hypericinece $\quad \ldots \quad \ldots \quad 180,186$

\section{I.}

Ilipurapubo ... $\quad$... $\quad \ldots \quad 213,218$ Imbrahim $\ldots . . . .38,43,50,51,191$

—— forests... ... ... 50

Imoi river ... $\quad \ldots . \quad \ldots . \quad \ldots .97$

Impasatia $\ldots \quad \quad \ldots \quad \ldots . \quad 57,60$

Impatiens livingii... $\quad \ldots \quad \ldots 178$

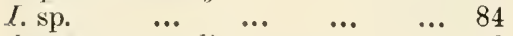

Imperata armulinaced $\quad \ldots \quad$... 72

Impriso $\quad \ldots \quad \ldots \quad \ldots . \quad \ldots \quad 96$

Incense tree, $\quad 36,37,57,175,177$

Indigo

$\begin{array}{llll}\text { Indigofera } & \ldots & \ldots & \ldots\end{array} \quad \ldots 70, \ddot{87}, 187$

Irolio $\quad \ldots \quad \ldots \quad 41,47,121,146$

Iringia Barteri ... 175, 177, 213, 219

Iyere $\quad$... $\quad \ldots \quad \ldots \quad \ldots 219$

$\begin{array}{llllll}\text { Iyere } & \ldots & \ldots & \ldots & \ldots & 219 \\ \text { lyeri } & \ldots & \ldots & \ldots & \ldots & 213\end{array}$

\section{J.}

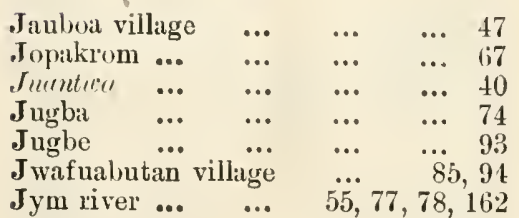

$\mathbf{r}$.

PAGES

Ka Krom $\quad . . \quad \ldots \quad \ldots \quad \ldots \quad \ldots 2$

Kulu, 10, 17, 19, 20, 21, 22, 23, 24, 26, $28,36,43,47,49,51,86,89,90$, $99,121,146,177,178,197$

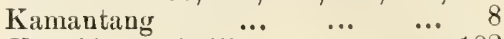

Kanchice consimilis $\quad \ldots . \quad \ldots 182$

Kankan $\quad \ldots \quad$... $\quad \ldots \quad 96,99$

Kemp's Peak $\quad \ldots \quad \ldots \quad \ldots \quad 55$

Kenyase Mohang ... ... $\quad 63,64$

Khayge, $17,26,28,35,37,38,39,40,41$, $42,44,51,55,56,62,64,66,77$, $80,81,83,121,123,145,174,175$, $197,198,213,218$

K. anthothecu (PI. 4), 58, 64, 75, 181, $184,196,197$

K. grundis (PI. 5), 61, 62, 72, 75, 79, $83,84,93,181,184,190,196,199$

K. Punchii (Pl. 6), 14, 20, 47, 72, 181, 184,190

$K^{r}$ senegulensis ( $\mathrm{Pl} .7$ ), b8, 69,70,73, $74,86,88,92,94,122,138,139$,

$174,187,189$

K. sp. (Pl. 8), 10, 20, 24, 32, 56, 57, $58,59,61,64,77,176,184,197$,

198

Kigcliu pinnuta $\quad \ldots \quad \quad \ldots \quad 70,188$ Kintampo $\ldots \quad \ldots \quad 67,75,93,160$ Kintampo forest ... ... .. 76 Kistice, $20,26,28,36,38,50,56,61$,

Kitta lagoon $\quad 70,87,175,177,197$

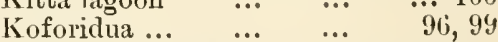

Kolioti, 10, 20, 24, 26, 2๙, 36, 37, 41, $47,48,49,57,61,64,81,83,84$,

$146,175,177$

Koliotsui $\quad \ldots \quad \ldots \quad \ldots \quad \ldots \quad \ldots 197$

Komoe river $\quad \ldots \quad \ldots \quad 64,161$

$\begin{array}{llllll}\text { Konkota } & \ldots & \ldots & \ldots & \ldots & 82\end{array}$

$\begin{array}{llllll}\text { Krachi } & \ldots & \ldots & \ldots & \ldots & 84 \\ & & \ldots & \ldots & \ldots & 94\end{array}$

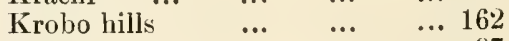

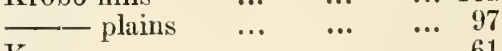

$\begin{array}{llllll}\text { Krom } & \ldots & \ldots & \ldots & \ldots & 61\end{array}$

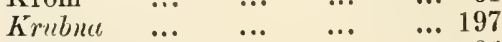

$\begin{array}{llllll}\text { Ки... } & \ldots & \ldots & \ldots & \ldots & 197 \\ \text { К } & \ldots & \ldots & \ldots & \ldots & 96\end{array}$

Kube $\quad \ldots \quad \ldots \quad \ldots \quad \ldots \quad 90,197$

Kukurantium $\quad \ldots \quad \ldots \quad \ldots 99$

Kumasi, $13,17,51,57,58,67, \dddot{7} 6,77$,

$162,164,165$

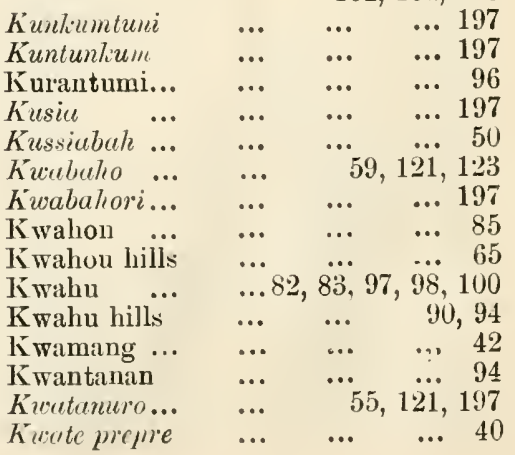


Kwisil $\quad \ldots \quad \quad \ldots \quad 76,77,78,79$

Kwitt: $\quad \ldots \quad \ldots, \quad \ldots, \quad \ldots 162$

Kyebi hills... $\quad \ldots \quad 99,162,191$

\section{I.}

Landolphire. $\quad \ldots \quad \ldots 10,45,77$

L. Drongneuresianea! $\quad \ldots \quad \ldots 177$

L. florida $\quad \ldots \quad$... 73, 182, 184, 190

L. Heudelotii $\quad \ldots \quad$... 70,185

L. Klaine ... $\quad 21,24,40,174,177$

L. omuriensis (PI. 2.2), 13, 36, 38, 40, $56,64,73,87,12 \cdot 2,138,146,174$, $177,182,184,188,189,190,213$ L. scundens... $\quad \ldots \quad \ldots \quad 182,184$ L. T7ompsonii, 62, 64, 73, 87, 182, 184 .

Lentisue camere ... ... ... 18:

Lecuniouliscus cupunivides _.. 181

Leeu $\quad$... $\quad \ldots \quad$... $\quad \ldots 187$

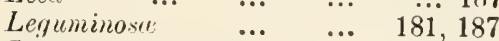

Liliucee $\quad \ldots \quad \ldots \quad 70,87,183,188$

Lippia udoensis $\quad \ldots \quad \quad \ldots \quad \quad \ldots \quad 18 \%$

Lissochilus ... $\quad \ldots \quad$... $\quad \ldots \quad 87$

L. longifolius $\quad \ldots \quad \quad \ldots \quad \ldots 178$

L. roseus $\quad \ldots \quad \ldots \quad 70,87,178,188$

Lithophytes $\quad \ldots \quad \quad \ldots \quad 74,172$

Locust bean $\quad \ldots \quad \quad \ldots \quad 87,187$

Locust bean tree ... $\quad \ldots .6 \quad \ldots \quad 69$

Lonchocurpus $\quad$... $\quad$... $\quad$... 174

L. cyanescens $\quad \ldots \quad \ldots \quad \ldots \quad 181,185$

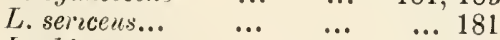

Lopkive $\quad \ldots \quad \ldots \quad \ldots \quad \ldots 146$

L. ulatu, 9, 70, 73, 86, 89,90, 188, 189

L. procere, $10,19,20,21,36,43,51,86$, $89,90,177,178,179,189,197$

L. procera? $\quad \ldots \quad$... $\quad \ldots \quad 17$

L. sp. $\quad \ldots \quad \quad \ldots \quad \quad \ldots \quad \ldots 121$

Lotoa $\quad \ldots \quad \ldots . \quad \ldots \quad \ldots 145$

L. Klaineanu (Pl. 9), 10, 17, 23, 36, 38, $55,78,121,123,175,176,196$,

Lower Denkira district ... 197, 198

IV.

Mucarcunget,... $\quad \ldots \quad \ldots \quad \ldots 175$ Vacrolubium I'ulisotii ... 21, 26, 178 II. stipulacenm $\quad \ldots \quad \ldots . \quad \ldots, 10,178$ Macrospleyra longistyla $\ldots . \quad \ldots \quad 182$ Mahogany, $37,48,51,62,69,72,75$, $77,79,81,86,88,92,121,123$, $126,145,176,184,213$

\begin{tabular}{|c|c|c|c|}
\hline \multicolumn{3}{|c|}{ Mahogany, West African... } & $\begin{array}{l}\text { PAGES } \\
18,21\end{array}$ \\
\hline Maize & $\ldots$ & $\ldots$ & 79 \\
\hline Ha Kube. & & & 90,197 \\
\hline ILalpighiacen. & . & & ... 180 \\
\hline Maleceser ... & ... & $\ldots$ & 180,186 \\
\hline Mampon ... & ... & ... & ... 162 \\
\hline langrove forest & ... & ... & ... 190 \\
\hline Wanikot Glarioei & i... & $\ldots$ & $\ldots$ \\
\hline M. precose ... & ... & .. & \\
\hline lansi river & & & $31,35,37$ \\
\hline Lanso & & & 46,47 \\
\hline Iansu N'Kwant & a... & & $56,57,58$ \\
\hline Mansu village & • & . & .. 2 \\
\hline Heryuclinium & .. & ... & 21,17 \\
\hline Meinshin ... & $\ldots$ & ... & $10,37,19$ \\
\hline Meluleucu ... & . & ... & ... 50 \\
\hline II. leucudendron & . & ... & $\tilde{e} 0$ \\
\hline Metustomacer & . & & $\pi$ \\
\hline Meliacew & & & 181,18 \\
\hline Mem & & & ... 16 \\
\hline lom Ber & 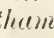 & (16) & ... 187 \\
\hline lesmis pulue & rula & & \\
\hline$M i$ & & $\ldots$ & \\
\hline
\end{tabular}

$\operatorname{Mim} \quad \ldots \quad 51,61,62,63,64,76^{2}$

Vimosu asperuta ... $\quad \ldots \quad 72,181$

Himusops Djuce (Pl. 20), 10, 18, 20, 27, $36,42,51,57,61,121,123,146$ $175,177,195,196$.

11. multinervis, $72,87,89,182,184,150$

II. sp. ؛ $\quad \ldots \quad \ldots \quad \quad \ldots \quad \ldots 198$

Mina mountains ... $\quad \ldots \quad \ldots 160$

Mirefuaso village ... _... _.. 81

Hitrugyne ufricane $\quad \ldots \quad 7 \pm, 178$

I. maeropleyllu, 10, 21, 36, 7:2, 177, 178 ,

Moliang 196,199

Molkang $\quad \ldots \quad$... $\quad \ldots \quad$... 63

Moinsin range $\quad \ldots \quad \quad \ldots \quad 78,162$

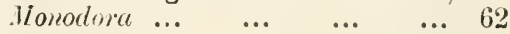

H. brexipes... $\quad \ldots \quad \ldots \quad \ldots 180$

MI. myristice $\quad$... $\quad \ldots \quad 21,175$

I. tenuifolia $\quad \ldots \quad \ldots \quad 21,175$

Monsoon folests $\ldots . \quad \ldots \quad \ldots \quad 179,185$

Mordants ... $\quad . . \quad \quad \ldots \quad \quad \ldots 189$

Iorelia senegalensis $\quad$... $\quad$.. 182

Morinda citrifoliu... $\quad$... $\quad \ldots 182$

II. longiflora $\quad \ldots . \quad \ldots . \quad \ldots 182$

Motandra guineensis $\quad$... $\quad \ldots 175$

Housanduc... ... ... $\quad$... 197

$\begin{array}{llllll}\text { Husanga } & \ldots & \ldots & \ldots & \ldots & 37\end{array}$

II. Smithii (Pl. 24), 10, 21, 25, 26, 29, $32,37,39,44,49,56,62,77,174$,

175

Mussaende...

21,174

M. erythrophylle ... $\quad$... $\quad 175,182$

M. splenders. $\quad$... $\quad \ldots . \quad \ldots 182$

II. temiflore $\quad \ldots . \quad \ldots . \quad \ldots 182$

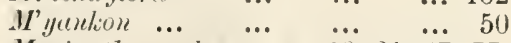

Myrianthus arboreses, $10,21,67,77$,

175,182

Myristica sp. $\quad \ldots \quad \quad \ldots \quad \quad \ldots \quad 20$

Myristice sp. ? $\quad \ldots \quad \ldots \quad \ldots \quad 10,198$

Myrtucer $\quad \ldots \quad \ldots \quad \ldots \quad \ldots \quad 183,187$ 
N.

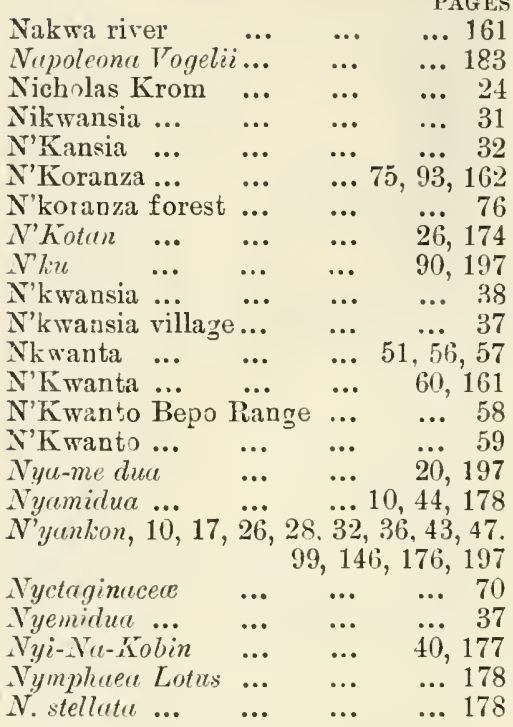

Oawengo $\quad \ldots \quad$... $\quad \ldots \quad \ldots 213$ Obo... $\quad \ldots \quad \ldots \quad \ldots \quad$... 93,97 Obo-Abetifi hills $\ldots . \quad \ldots . \quad \ldots 162$ Oboase $\quad \ldots \quad 51,55,56,68,74,93$ Oboase hills $\quad \ldots \quad \ldots \quad \ldots 162$ $\begin{array}{llll}\text { Obusumbone rirer } & \ldots & \ldots & 94\end{array}$ $\begin{array}{llllll}\text { ()dahume } & \ldots & \ldots & \ldots & \ldots & 198\end{array}$ $\begin{array}{llllll}\text { Udenya } & \ldots & \ldots & \ldots & \ldots & 198\end{array}$ Odoum, $10,18,20,23,24,26,27,32$, $36,37,38,39,41,42,44,47,51$, $55,56,57,58,59,60,61,62,64$, $72,75,77,78,79,80,81,83,84$, $121,123,124,146,175,176,184$,

$\begin{array}{llllll}\text { Odum } & \ldots & \ldots & \ldots & \ldots & 198\end{array}$ Odumase $\quad \ldots \quad \ldots . \quad \ldots \quad \quad \ldots 57,80$ Odumase village $\ldots . \quad \ldots \quad \ldots \quad \ldots 59$ $\begin{array}{llllll}\text { Odupin } & \ldots & \ldots & \ldots & \ldots & \ldots 9 \\ & \ldots & \ldots & \ldots & & \end{array}$ Odupon $\quad \ldots . \quad \ldots \quad \ldots \quad \ldots \quad \ldots 198$ Odwen $\quad \ldots \quad \ldots . \quad \ldots \quad \ldots \quad 89$

Cffin river, $48,49,51,52,53,56,58$, $59,60,160,161,162$ Ofform, 10, 19, 20, 22, 23, 25, 26, 28, $34,36,37,38,39,41,43,44,47$, $48,50,55,56,57,58,62,64,75$, $77,78,79,80,81.83,84,146,174$, $176,177,183,184,198$

Ofina stream

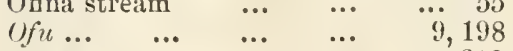
$\begin{array}{lllll}\text { Üquango } & \ldots & \ldots & \ldots & \ldots 218\end{array}$

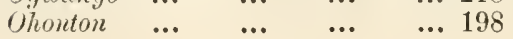

PAGES

Oil bean tree, $20,28,36,48,55,122$, $123,146,211$

Oil nut $\quad \ldots \quad \ldots . \quad \ldots \quad \ldots 211$

Oil palm, 10, 15, 37, 41, 74, 87, 175, 177. 184,190

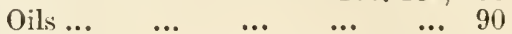

$\begin{array}{lllllll}\text { Olian } & \ldots & \ldots & \ldots & \ldots & \ldots & 35\end{array}$

Okisibiri $\quad \ldots 26, \dddot{3} \overline{7}, 83, \dddot{17} 5,17 \ddot{7}, 198$

Olitsiwanfu $\quad$... $\quad$... $\quad \ldots 198$

$\begin{array}{lllll}\text { Okpara river } & \ldots & \ldots & \ldots & 73\end{array}$

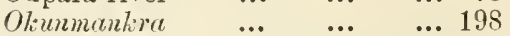

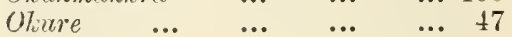

Okwawu hills $\quad \ldots \quad \ldots \quad \ldots \quad \ldots 160$

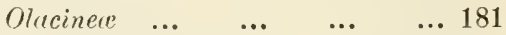

Oldenlandia $\quad \ldots \quad \ldots 70,87,188$

Oldfeldia africuna $\quad \ldots \quad 211,216$

Olnkemeji ... $\quad \ldots \quad \ldots \quad \ldots \quad \ldots \quad 14$

Olokemeji Gardens $\quad$... $\quad \ldots \quad 12$

$\begin{array}{lllll}\text { Ombrophoby } & \ldots & \ldots & \ldots & \ldots\end{array}$

Omphalocermem $\quad \ldots \quad \ldots \quad \ldots 174$

$\begin{array}{lllll}\text { O. sp. ? } & \ldots & \ldots & \ldots & 36,196\end{array}$

Oncobe dentute $\quad \ldots . \quad \ldots . \quad \ldots 180$

O. spinosit $\ldots \quad \ldots \quad \ldots \quad \ldots . \quad \ldots 180$

Onomokyulyue $\quad \ldots \quad \ldots \quad 211,216$

$\begin{array}{llllll}\text { Ongina } \quad \ldots & \ldots & \ldots & \ldots & 198\end{array}$

$\begin{array}{llllll}\text { Onyine } & \ldots & \ldots & \ldots & \ldots & 198\end{array}$

Opapea $\quad \ldots \quad \ldots \quad \ldots . \quad \ldots 198$

Opapoa $\quad \ldots \quad 9,69,88,122,189$

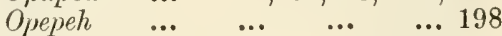

$\begin{array}{llllll}\text { Opobo } & \ldots & \ldots & \ldots & \ldots 1 & 198\end{array}$

Opobonikwi... $\quad \ldots \quad \ldots \quad 211,216$

$\begin{array}{llll}\text { Opobonufica } & \ldots & \ldots & 211,216\end{array}$

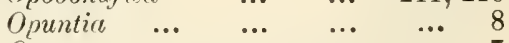

$\begin{array}{llllll}0 . \mathrm{sp} . & \ldots & \ldots & \ldots & \ldots & 7\end{array}$

Orchidacee... $\quad \ldots \quad \ldots \quad 70,188$

Orchids $\quad \ldots \quad$... $\quad \ldots . \quad \ldots 178$

Ordeal tree... $\quad \ldots \quad \ldots \quad \ldots \quad \quad \ldots 6,89$

Ormosic laxiftore ... $\quad 9,69,86,187$

$\begin{array}{lllll}\text { Oroko } & \ldots & \ldots & \ldots & 211,216\end{array}$

Osuabise $\quad \ldots \quad \ldots . \quad \ldots 99991,198$

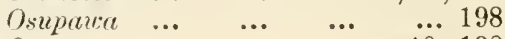

Ote $\ldots \quad \ldots \quad \ldots \quad \ldots \quad \ldots \quad 10,198$

$\begin{array}{llllll}\text { Otte } \ldots & \ldots & \ldots & \ldots & \ldots & 20\end{array}$

Oramu $\quad \ldots \quad 10,57, \dddot{58}, 59, \ddot{84}, 198$

$\begin{array}{llllll}\text { Ounerea } & \ldots & \ldots & \ldots & \ldots & 198\end{array}$

$\begin{array}{lllll}\text { Oxyanthus tubiftorus } & \ldots & \ldots & 198\end{array}$

Orytenunthera abyssinica ... 70, 70

$\mathbf{P}$.

$\begin{array}{llllll}\text { I'adank } & \ldots & \ldots & \ldots & \ldots & 15\end{array}$

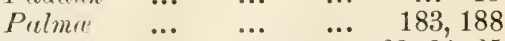

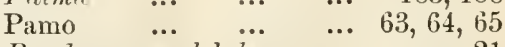

Pendenus candelabrum $\ldots . \quad \ldots 21$

$\begin{array}{lllll}\text { Panicum } & \ldots & \ldots & \ldots & 70\end{array}$

Papaieracer $\quad \ldots \quad \ldots . \quad \ldots \quad \ldots 186$

$\begin{array}{lllll}\text { Papoa } & \ldots & \ldots & \ldots & 86,184\end{array}$

Para trees ... $\quad \ldots \quad$... $\quad$.. 13 
PAGES

$\begin{array}{lllll}\text { Purinarium } & \ldots & \ldots & \ldots & 9\end{array}$

P. curatcllifolium ... $\quad \ldots .70,87,91$, 187

P. mobola ... $\quad \ldots \quad \ldots 70,87,187$

$\begin{array}{llll}P \text {. polyandrum } & \ldots & \ldots & \ldots, 87,187 \\ P & \ldots & \ldots & \ldots\end{array}$

P. robustum $\quad$... $\quad \ldots .181,184$

P. sp. $\quad$.. $\quad \ldots \quad 175,181,196$

P. sp. ? $\quad \ldots \quad \quad \ldots \quad \ldots \quad \ldots \quad \ldots, 19$

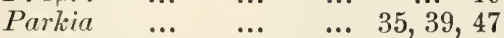

$P$ biglobnsa... $\quad \ldots \quad 10,57,67,84$

$P$. filicoidea $\quad \ldots 9,69,87,91,187$

P. sp. $\quad$... 9, 19, 20, 23, 26, 37, 39,

$41,48,175$.

Passitlorer ... $\quad \ldots \quad$... $\quad \ldots .183$

Paulluniq. pinnata ... $\quad$... $\quad$... 181

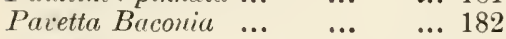

Pebèdoum ... $\quad$... $\quad \ldots \quad$ 23, 36

Pebedum ...17, 38, 41, 42, 55, 78, 121, $123,175,176,198$

Peltophorum, sp. ... ... 10, 62, 197

P. sp. ? ... $\quad$.. $\quad \ldots \quad \quad \ldots \quad 37$

Pentua, 10, 55, 83, 121, 123, 176, 198

Pentaclethra macropleylla... 10, 20, 26, $28,34,36,44,48,49,55,77,122$, $123,146,175,177,196,197,213$,

Pentadesina butyracea. $\quad \ldots \quad 175,177$

Pepedum ... $\quad$... $\quad$... $\quad \ldots \quad 10$

Peperomia Fugelii... _.. _.. 183

Phorix recliuata ... $\quad 70,74,87,188$

Phrynium ... $\quad \ldots . \quad \ldots \quad 75,180$

P. Benthaini $\quad$... $\quad$... $\quad \ldots 183$

$P$ brachystachys ... $\quad \ldots \quad$... 183

P. Dauielli... $\quad \ldots . \quad \ldots . \quad \ldots 183$

\begin{tabular}{lllll} 
Phyllanthus & $\ldots$ & $\ldots$ & $\ldots$ & 78 \\
\hline & & $\ldots$ & $\ldots$ & 70
\end{tabular}

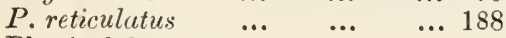

Physical features ... $\quad$... $\quad$... 160

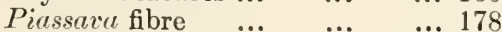

Piperacea ... ... ... ... 183

Piptadenia... 39, 41, 44, 56, 57, 62, 64

P. africumu (Pl. 16), 9, 10, 20, 28, 37, $39,50,55,58,62.67,72,77,81$, $84,154,174,175,176,177,181$, $183,184,197,198$

P. sp. (Pl. 17), 27, 35, 39, 42, 45, 48, $55,81,83,175,196,197,198$

Pistiu strutiotcs ... $\quad$... ... 178

Pithecolobium sumun $\quad$... $\quad \ldots \quad$ 7

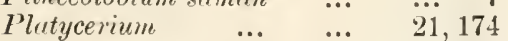

Plcioccras Burteri ${ }^{\ldots} \quad \ldots . \quad \ldots 182$

Polyadon umbelluta $\quad 72,182,190$

Potrodom ... ... 89

Pra river $\ldots 18,52,160,162,190,191$

Prah river ... $\quad . . \quad \ldots \quad 46^{\circ}, 48^{\circ}$

Prahso village $\quad \ldots \quad$... $\quad \ldots \quad 83$

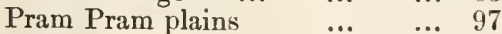

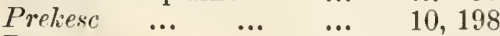

$\begin{array}{llll}\text { Prestea } & \ldots & \ldots & \ldots\end{array}$

Prestea mines $\quad \ldots \quad \ldots \quad 29,30$

Prestea mining camp $\quad \ldots \quad \quad 25,32$

Princessu ... $\quad \ldots \quad$... $\quad 47,48$

$\begin{array}{llllll}\text { Princesu } & \ldots & \ldots & \ldots & & \\ & \text { Prop } & & & & \\ & & \ldots & \ldots & \ldots & 46\end{array}$

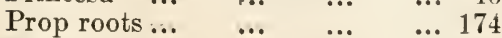

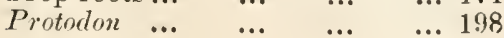

PAGES

Pru river ... $\quad \ldots \quad$... $\quad \ldots \quad 76$

Pscudocedrela, $\quad 26,28,34,35,37,38$, $39,40,42,44,47,51,55,62,64$, $66,77,79,80,121,145,174,175$, 213,218

P. cyliudricu (Pl. 10), 10, 20, 27, 36, $56,58,83,176,198$

P. Kotschyi (Pl. 11), 69, 70, 73, 86 . $88,122,138,139,187,189$

P.utilis? (Pl. 15), 60, 62, 64, 181, 184 ,

P. sp. (Pl. 12), 9, 10,32, 41, 45, 55, $58,61,66,67,77,83,84,176,198$ Pseudospondias microcarpa $\ldots 181$ Psorospermum ... ... $\quad$... 186 $\begin{array}{llllll}P . \text { sp. } & \ldots & \ldots & \ldots & \ldots & \end{array}$ Pterocarpus sp. $\quad \ldots \quad \ldots \quad \ldots \quad$ $\ldots 7,58$ $P$. erinaccus, $9,69,86,89,187,189$ $P$. esculentus, $\quad 72,87,178,181,190$ $P$. indicus ... $\quad . . \quad \ldots . \quad \ldots, 15$ Puliamo $\quad \ldots \quad 64,65,66,67,191$ Punkwu, 20, 36, 40, 41, 47, 58, 60, 61, $121,1 \% 3,176,198$

Pynaertia ealaensis, 10, 20, 24, 36, 49, $57,61,66,84,146,175,177,196$,

197

Puisqualis indica ... $\quad \ldots \quad$... 181

R.

Rainfall $\quad \ldots \quad \ldots . \quad \ldots \quad \ldots 162$

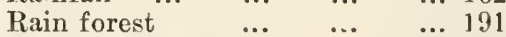

Rourtir nuruluta $\ldots . \quad \ldots \quad \ldots \quad 72,182$

R. malleifera $\quad \ldots \quad$... $\quad \ldots .187$

Rirplice $\quad \ldots \quad \ldots \quad \ldots 46,74,87$

Raphia palm $\quad . . . \quad \ldots \quad \ldots 67$

Rupleia vinifcre $\quad 39,56,62,178,183$,

$185,190,198$

Ruplidopliore $\quad \ldots \quad$... $\quad 21,174$

Ruuwolfia ... $\quad \ldots . \quad \ldots . \quad \ldots \quad 77$

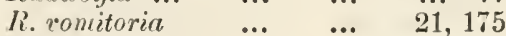

Red iron- wood $\quad \ldots \quad \quad \ldots \quad \quad \ldots \quad 19$

Rlummucex $\quad$... $\quad$... $\quad$... 188

Rhizophora rucemosi $\quad$... $\quad$... 190

R. mangle ... $\quad$... $\quad$... $\quad$... 190

Ricinodentron africums, 10, 20, 23, 27 , $34,36,55,57,58,72,77,80,83$, $84,87,90,122,123,146,175,176$, $177,183,184,190,196,198$

Rosacea $\quad \ldots \quad \ldots \quad \quad \ldots \quad 181,187$

Rosewood tree $\quad \ldots \quad \ldots . \quad \ldots \quad 69,89$ 
PIGES

Rubber $\quad \ldots \quad$... $\quad \ldots \quad$... 189 Rubber, rules relating to... $\quad \ldots 118$ Rubber-yielding plants ... ... 177 Rubiaces $\ldots \quad$... $\quad 70,182,187$ Rutuceu $\quad$.. $\quad \ldots \quad$... $\quad \ldots 180$

\section{S.}

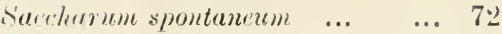
Surcherum spontuneum? ... $\quad \ldots \quad 37$ Sacred Forest $\quad \ldots \quad$... $\quad \ldots .50$ Śadang village $\quad \ldots \quad \quad \ldots \quad \quad 90,94$ Salt Pond district... ... ... 161 Samanta $\quad \ldots \quad \ldots 26,37,58,59,198$ Sennerevineu $\quad$... $\quad$... $\quad$... 198

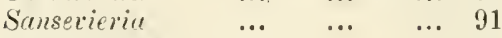
S. grineensis $\quad \ldots . \quad \ldots \quad \ldots 18$. $\begin{array}{llllll}\text { S. sp. } & \ldots & \ldots & \ldots & \ldots & 189 \\ & & \ldots & \ldots & \ldots & 70\end{array}$ Suntiriopsis Kluinci $\quad 36,57,81,175$ Sespindacer $\quad \ldots \quad \quad \ldots \quad \ldots 181$ Sitpotucer $\quad \ldots \quad$... $\quad \ldots \quad$ 18:, 188 Surcorepluilus esculentus (P1. 18), 9, 16. $20,26,36,70,87,92,175,177$. 188,197 Sarcocephalus Russeggcri... 21, 178 S. sp. $\quad \ldots \quad \quad \ldots \quad \quad \ldots \quad 56,198$ Sarmang $\quad \ldots \quad \quad \ldots \quad \ldots \quad \ldots \quad \ldots 160$ Sass wood ... $68,69,86,89,122,187$ Sausage tree $\quad$... $\quad \ldots \quad \ldots 188$ Savannahs ... $\quad \ldots . \quad \ldots . \quad \ldots 190$ Scitaminece... $\quad \ldots \quad 75,180,183$ Schrebera golungensis $\quad$... 72,190 S. sp. $\quad \ldots \quad \quad \ldots \quad \ldots . \quad \ldots \quad 72$

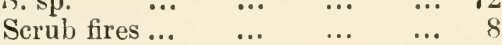
Seasons $\quad \ldots \quad \ldots \quad \ldots \quad \ldots 163$ \begin{tabular}{lllll} 
& $\ldots$ & $\ldots$ & $\ldots$ & $\ldots$ \\
\hline
\end{tabular} —- Small dry $\quad \ldots . \quad \ldots 163$ - Tornado ... $\quad$... ... 163 Sefwi $\quad \ldots \quad \quad \ldots \quad \quad \ldots \quad 97,191$ Sekondi $\quad \ldots \quad 16,17,49,53,62,162$ Sene.river ... $\quad . . \quad \quad \ldots \quad 94,160$ Sese... $\quad \ldots \quad \quad \ldots \quad \quad \ldots \quad \ldots 198$ $\begin{array}{lllll}\text { Shama } & \ldots & \ldots & \ldots & \ldots\end{array}$

Shea butter tree, $9,73,8 \ddot{87}, 90,91,94$, $122,188,189$

Shedua $\quad \ldots \quad$... $\quad$... $\quad \ldots \quad 77$ Shingle tree $\quad \ldots \quad \ldots \quad \ldots \quad 10,77,79$ Shingle-wood tree... ... 78,84 Sibiri stream, $\quad 31,38,39,40,4 i, 48$ Sidu... $\quad$... $\quad \ldots 70,180,185,186$ Sikas-siko $\ldots, \quad \ldots \quad$... $\quad \ldots \quad \ldots 68$ Sikassiko $\quad . . \quad$... $\quad$... $\quad \ldots \quad 73$ Silk-cotton tree, $19,27,37,38,40,41$, $70,72,73,81,87,174,176,186$, 187,198

Silk-rubber tree, 43, 61, 146, 175, 183 Simuruber ... $\quad . . \quad \quad \ldots \quad \quad \ldots \quad 181$ $\begin{array}{llllll}\text { Sirilio } & \ldots & \ldots & \ldots & \ldots & 181 \\ \text { Simall } & \ldots & \ldots & \ldots & \ldots & 40\end{array}$ $\begin{array}{lllll}\text { Small rains... } & \ldots & \ldots & \ldots & 403\end{array}$
I'AGES

Smerthmamia pubescens ... ... 183

Smilucere $\quad \ldots \quad$... $\quad \ldots \quad$... 188

Smilex Kranssiana $\quad$... $\quad 70,188$

Soil ... $\quad \ldots . \quad \ldots . \quad \ldots . \quad \ldots 365$

Sprethoder compunulutu $\quad 72,182,190$

Spilumes ucmella... ... ... 70

Spondirs luter $\quad \ldots$ 72, 181, 185, 190

Staff, European ... ... ... 143

_- Subordinate $\quad$... $\quad \ldots 155$

Sterculire $\ldots . \quad \ldots \quad \ldots . \quad \ldots \quad 59$

S. Burteri, 45, 55, 57, 58, 61, 64, 72, 81, $83,84,87,91,180,185,190$

S. curdifoliu, $10,37,43,45,55,56,57$, $58,62,6\rfloor, 66,72,81,83,84,87$, $180,185,190,197,199$

S. ionentosu, 57, 58, 61, 62, 64.72, 180 ,

185,190

S. tragucumitu $\quad \ldots \quad$... $\quad \ldots 180$

Sterculiacer $\quad \ldots \quad \ldots \quad$... 180,187

Stink-wood trees ... ... ... 37

Strophanthus $\quad \ldots . \quad \ldots 38,77,174$

S. grutus $\quad \ldots \quad$... $\quad \ldots \quad$... 182

S. hispidus ... $\quad \ldots . \quad \ldots \quad \ldots \quad \ldots 182$

S. Ireussii ... $\quad \ldots \quad$... $\quad \ldots 182$

S. surmentosus $\quad \ldots \quad \quad \ldots \quad \quad \ldots 182$

$\begin{array}{llllll}S . ~ s p . & \ldots & \ldots & \ldots & \ldots & 62\end{array}$

$\begin{array}{llllll}\text { Strychnos } & \ldots & \ldots & \ldots & \ldots & \\ \text { St. } & \ldots & \ldots & 74\end{array}$

S. pmatrginatu $\quad \ldots \quad \ldots \quad \ldots \quad 87,188$

Subinsu stream $\quad \ldots \quad$... $\quad \ldots \quad 55$

Sudd weed ... $\quad$... $\quad \ldots . \quad \ldots 178$

Sumin river $\quad \ldots \quad 8 \tilde{5}, 90,94,160$

Suminsu $\quad \ldots \quad$... $\quad \ldots \quad$... 94

Supon $\quad$... . ... $\quad \ldots \quad 46,47,48$

Swamp vegetation $\quad \ldots . \quad \ldots 21$

Swieteniu mucrophylla $\quad \ldots \quad$... 14

S. Mahogani $\quad$... $\quad$... $\quad$... 14

I.

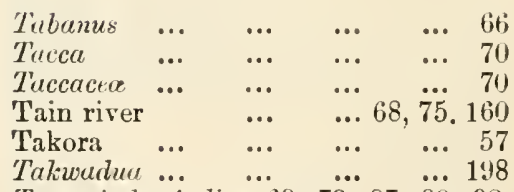

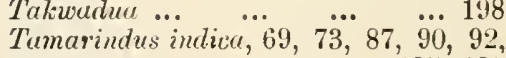
187,189

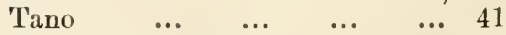

Tano-Ankobra water-paiting $\quad$.. $\quad 32$

Tano ricer, 24, 31, 38, 42, 43, 44, 45, $46,49,51,52,61,62,63,160,161$,

190,191

Tano river basin ... $\quad \ldots \quad \ldots 176$

Talloso $\quad . . \quad$... $\quad \ldots \quad 52,61$

Tarkwa $\quad \ldots \quad \ldots 13,24,25,83,191$

Tarkwa mines ... ... 49, 50

Teak tree, Eist Indian ... ... 14

$\begin{array}{llll}\text { Techerabini } \quad \ldots & \ldots & 64,65\end{array}$

Tectona grandis $\quad \ldots \quad \ldots \quad \ldots \quad 14,38$ 
Tendo lagoon $\quad \ldots \quad \ldots \quad \ldots 160$

Tephrosic ... $\quad \ldots \quad \ldots 70,87,187$

Terminalia... $\quad \ldots . \quad \ldots \quad \ldots 58$

1. Brownei... $\quad \ldots 72, \dddot{177}, 1 \ddot{181}, 184$

T. mercropter'i $\quad \ldots \quad$... 70,187

1. scutifer $\epsilon_{\ldots} . . \quad \ldots \quad \ldots 10,72,146$

T. superba, 10, 19, 20,34, 36, 66, 174,

$175,176,177,181,183,184,190$,

T. sp. $\quad \cdots \quad 10,20, \ddot{36}, 55, \ddot{5} 7,58$,

$66,77,81,86,146,175,176,177$, $181,183,184,197$

Tetrapleare Thomningii, 10, 20, 39, 55, $64,67,175,198$

Tieme-Tiame, $10,32,36,40,41,45$, $47,55,56,58,59,60,61,64,67$ $121,123,176,184,198$

Tiliecer. $\quad \ldots \quad \ldots . \quad \ldots \quad 180,187$

Timber, sules relating to... $\quad \ldots \quad 122$

Timber trees $\quad \ldots \quad \ldots \quad \ldots \quad$... 88

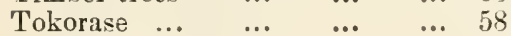

Tomba river $\quad \ldots \quad \ldots, \quad \ldots 8,74$

$\begin{array}{lllll}\text { Tombo } & \ldots & \ldots & \ldots & \ldots \\ \text { Tombo } & \ldots & \ldots & \ldots 198\end{array}$

Tombo palm $\quad \ldots \quad 21,39,62,178$

Tomento $\quad \ldots \quad \ldots \quad 42,43,44,52$

Tomento village $\quad \ldots \quad \ldots \quad \ldots \quad \ldots \quad 46$

$\begin{array}{lllll}\text { Tomme river } & \ldots & \ldots & \ldots & \\ \text { Tom } & \ldots & \ldots & 74\end{array}$

Tonkomia $\ldots \quad \ldots \quad \ldots \quad \ldots \quad 73,74$

$\begin{array}{lllll}\text { Totonso } & \ldots & \ldots & \ldots & 46,47,48\end{array}$

Treculia africana ... $\quad \ldots \quad$... 178

Triaspis $\quad \ldots \quad \ldots \quad \ldots \quad \ldots \quad \ldots 174$

Trichilia $\quad \ldots \quad \ldots \quad \ldots \quad \ldots \quad 213,218$

Trichilie sp. $\quad \ldots \quad \ldots \quad 42,175$

Triplochiton Johnsonii (PI. 2), 10, 19. $20,34,37,57,58,66,77,84,154$, $174,175,176,177,183,198,199$

Tristemma hirtum... $\quad . . \quad \ldots 70$

Triumfetta, 22, 91, 177, 180, 185, 187,

$\begin{array}{lllll}T \text {. corrlifolia } & \ldots & \ldots & \ldots & 70\end{array}$

$\begin{array}{lllll}\text { T. rhomboilen } & \ldots & \ldots & \ldots & 70 \\ & & \ldots & \ldots & 70\end{array}$

Tropophytes $\quad \ldots \quad \ldots \quad \ldots 167$

Tsifufu Forest ... ... 51, 55

$\begin{array}{llllll}\text { Tuna } & \ldots & \ldots & \ldots & \ldots & 66\end{array}$

\section{v.}

PAGES

Vegetation on clearings ... $\quad \ldots \quad 21$

Verbenacece $\quad \ldots \quad \quad \ldots \quad 182,188$

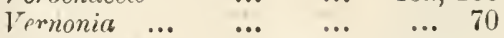

Vernonia frondose $\quad \ldots, \quad \ldots, 21$

Titex moneatu, 9, 16, 66, 70, 87, 188

T. macrophyllı $\quad \ldots \quad \quad \ldots \quad \quad \ldots .16$

V. meguphylla $\quad \ldots 9,6 \dddot{66}, 70,8 \ddot{8}, 188$

Voacunga africann $\quad 21,175,182$

$\begin{array}{llllll}\text { Volta } & \ldots & \ldots & \ldots & \ldots & 94\end{array}$

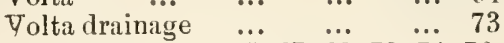

Volta river... (6i, $67,68,73,74,76$, $85,90,92,95,160,161$

Wagadugu ... $\quad \ldots \quad \ldots \quad \ldots 160$

Wansameah $\quad$... $\quad \ldots . \quad \ldots 199$

Wassaw district $\ldots . \quad \ldots \quad 24,191$

Wassaw hills $\quad \ldots \quad$... $\quad$... 83

Water partings $\quad \ldots . \quad \ldots \quad \ldots 161$

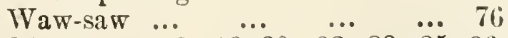

Waw-zvaw, 10, 19, 20, 22, 23, 25, 26, $28,32,37,38,39,41,42,43,44$, $47,48,50,57,58,59,75,77,80$ $81,83,84,154,155,175,176,177$, 183, 184,199

Hater $\quad$... $\quad$.. $\quad \ldots \quad$... 199

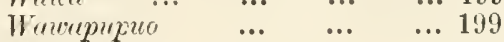

Wet season... $\quad \ldots \quad \ldots \quad \ldots \quad \ldots 163$

White Volta $\quad \ldots \quad \ldots . \quad \ldots 160$

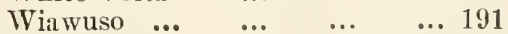

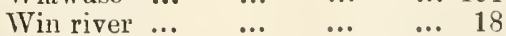

Winds, dry... $\quad \ldots \quad \ldots \quad \ldots 170$

Winneba river $\quad \ldots \quad \ldots \quad \ldots \quad \ldots 161$

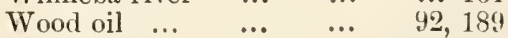

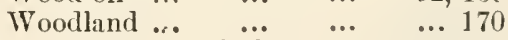

Woodland, Tropical $\quad \ldots \quad \ldots 172$

\section{x.}

$\mathbf{u}$.

Umbrella tree, $21,25,29,32,56,77$,

174,175 .

Upper Wawsaw ... $\quad . . \quad \ldots \quad 4 \%$

Urena, $\quad 22,70,91,177, \dddot{1} 80,185,186$,

Uropleyllum hirtellum

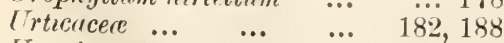

Sinthoxylum senegralense, $72, \quad 180$,

184,190

$\begin{array}{llll}\text { Xerophytes } \quad \ldots & \ldots & 167,169\end{array}$

Ximeniu americana. $\quad . . \quad \ldots 181$

Xylir Exansii, 26, 37, 44, 58, 64, 66,

$181,184,198$

Tylopia aethiopica $\quad$.. $\quad \ldots 180$

I. purviflora $\quad \ldots \quad \ldots \quad \ldots 180$ 


\begin{tabular}{|c|c|c|c|c|c|c|c|c|c|}
\hline & & $\mathbf{Y}$. & & & & & & & PAGES \\
\hline & & & & PAGES & Yenebin & $\cdots$ & $\cdots$ & $\cdots$ & ... 60 \\
\hline Yams & $\ldots$ & $\cdots$ & $\cdots$ & 79,93 & Yoruba & $\ldots$ & ... & $\ldots$ & ... 87 \\
\hline Yankom & $\ldots$ & $\ldots$ & $\ldots$ & 51,199 & & & & & \\
\hline Yankon & $\ldots$ & $\ldots$ & $\ldots$ & $\ldots 10$ & & & & & \\
\hline Yanliun & $\ldots$ & $\ldots$ & $\ldots$ & ... 199 & & & & & \\
\hline Yapiakrom & village & & $\ldots$ & 57,59 & & & & & \\
\hline Yar-Yar & $\ldots$ & $\ldots$ & $\ldots$ & ... 199 & & & $\mathbf{z}$. & & \\
\hline$Y a-Y a$ & $\ldots$ & $\ldots$ & $\ldots$ & ... 199 & & & & & \\
\hline Taya. & .. & $\ldots$ & $\ldots$ & 10,36 & Zizyphus & & & $\ldots$ & ... 87 \\
\hline Yenabin & $\ldots$ & $\ldots$ & $\ldots$ & ... 60 & Z. mucron & ata & $\ldots$ & $\ldots$ & $9,70,188$ \\
\hline
\end{tabular}


The following recent reports relating to His Majesty's Colonial Possessions have been issued, and may be obtained from the sources indicated on the title page :-

\section{ANNUAL.}

No.

$\overline{591}$

592

593

594

595

596

597

598

599

600

601

602

603

604

605

606

607

608

609

610

611

612

613

614

615

616

617

618

619

620

621

622

623

624

625

626

627

628

629

Colony, \&c.

Year.

Leeward Islands ... $\quad$...

East Africa Protectnrate...

Bechuanaland Protectorate

Northern Nigeria ... ...

Basutoland... ... $\quad .$.

$\begin{array}{lll}\text { Swaziland ... } & \ldots & \ldots \\ \text { St. Helena } . . . & \ldots & \ldots\end{array}$

Gibraltar $\ldots \quad \ldots . \quad \cdots$

Falkland Islands ...

Uganda

Imperial Institute

Northern Territories of the Gol $\dddot{d}$ Coast

Ashanti

Ceylon

Weihaiwei ...

Serchelles ...

...

Jamaica $\quad . . \quad \ldots \quad \ldots$

Colonial Survey Committee

Gambia

Malta

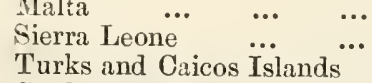

Gold Coast...

Bechuanaland Protectorate

Bahamas

St. Luci $\cdots \quad \ldots \quad \ldots$

$\begin{array}{lll}\text { St. Lucia } \ldots & \ldots & \ldots\end{array}$

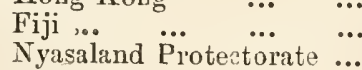

Barbados

Trinidad and Tobaco

Straits Settlements

Somaliland Protectorate ...

Mauritius ... $\quad . . . \quad \ldots$

St. Vincent..

$\begin{array}{lll}\text { St. Vincent... } & \ldots & \ldots \\ \text { Jamaica } & \ldots & \ldots\end{array}$

Swaziland ....

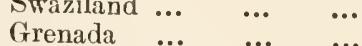

Leeward Islands..

\section{MISCELLANEOUS.}

No.

Colony, \&c.

Subject.

\begin{tabular}{|c|c|c|c|}
\hline \\
\hline British Colonies & & & ... Fibres. \\
\hline Northern Nigera & $\cdots$ & $\cdots$ & ... Mineral Survey, 1906-1907. \\
\hline Nyasaland Protector & rate & ... & $1907-1908$ \\
\hline South Africa ... & $\cdots$ & $\cdots$ & ... Agriculture and Viticulture. \\
\hline $\begin{array}{l}\text { Uganda } \\
\text { Imperial Institute }\end{array}$ & $\cdots$ & $\cdots$ & ... Cotton Industry. \\
\hline $\begin{array}{l}\text { Imperial Institute } \\
\text { Uganda }\end{array}$ & $\cdots$ & $\cdots$ & ... Gums and Resins. \\
\hline Uganda & $\cdots$ & $\cdots$ & $\begin{array}{l}\text {... Botanical and I urestry Depart- } \\
\text { ment. }\end{array}$ \\
\hline
\end{tabular}

... Sleeping Sickness.

..

-...

-..

$\cdots$

...

$1907^{\prime \prime} 1908$

1908

1)

9

"

,

1907-1908

1908-1903

1908

1908-1909

1908

",

1908"1909

19908

",

1908-1909

"

1908

1908-1909

1908

1908-1909

,

1908

1908-1909 





\section{LIBR:A| \\ FACULTY OF FORESIA. \\ UNIVERSITY OF TORONTO}

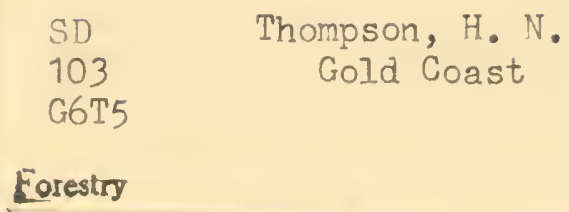

MAR I 995 


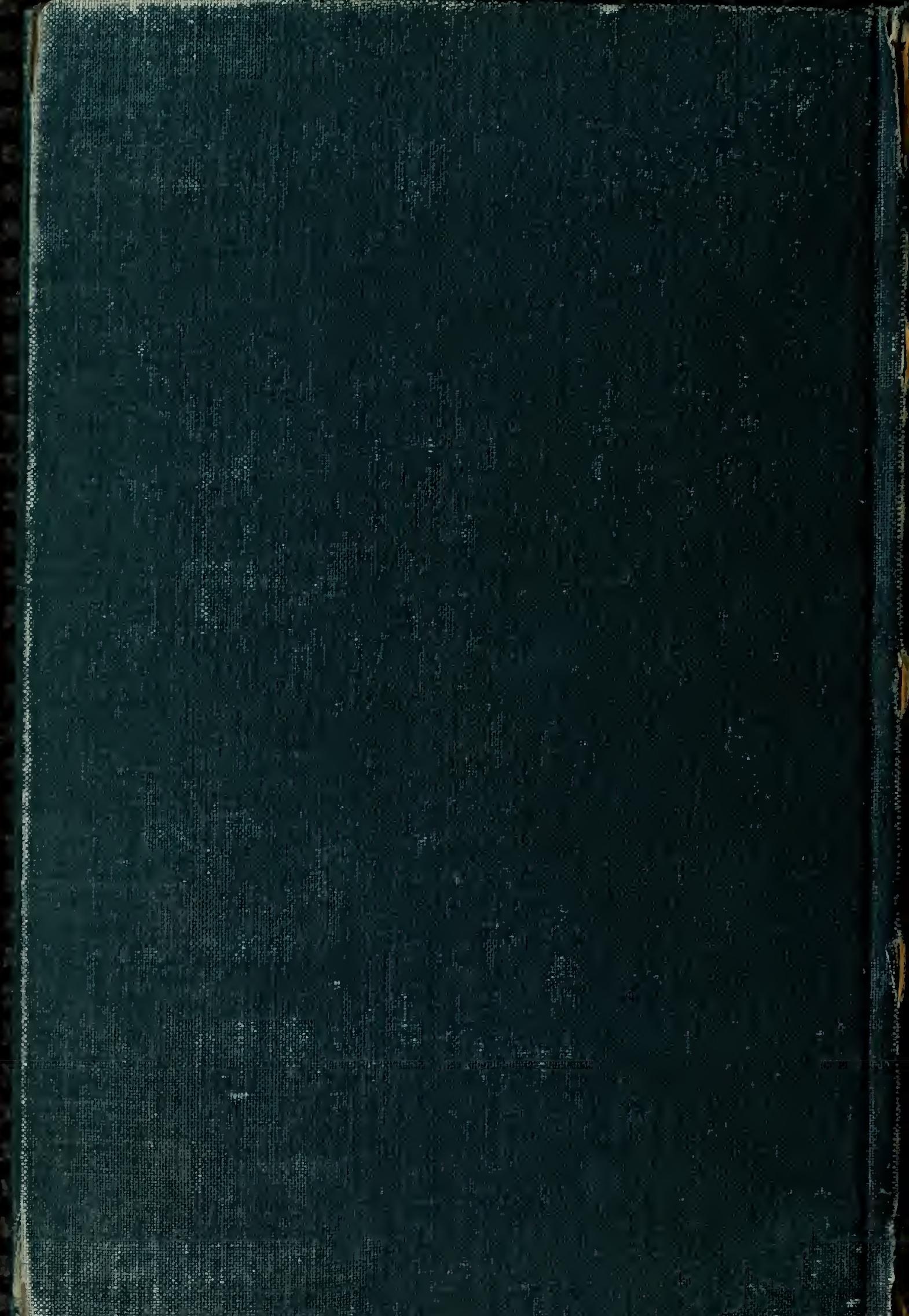

